\title{
Range Plant Community Types and Carrying Capacity for the Subalpine and Alpine Subregions
}

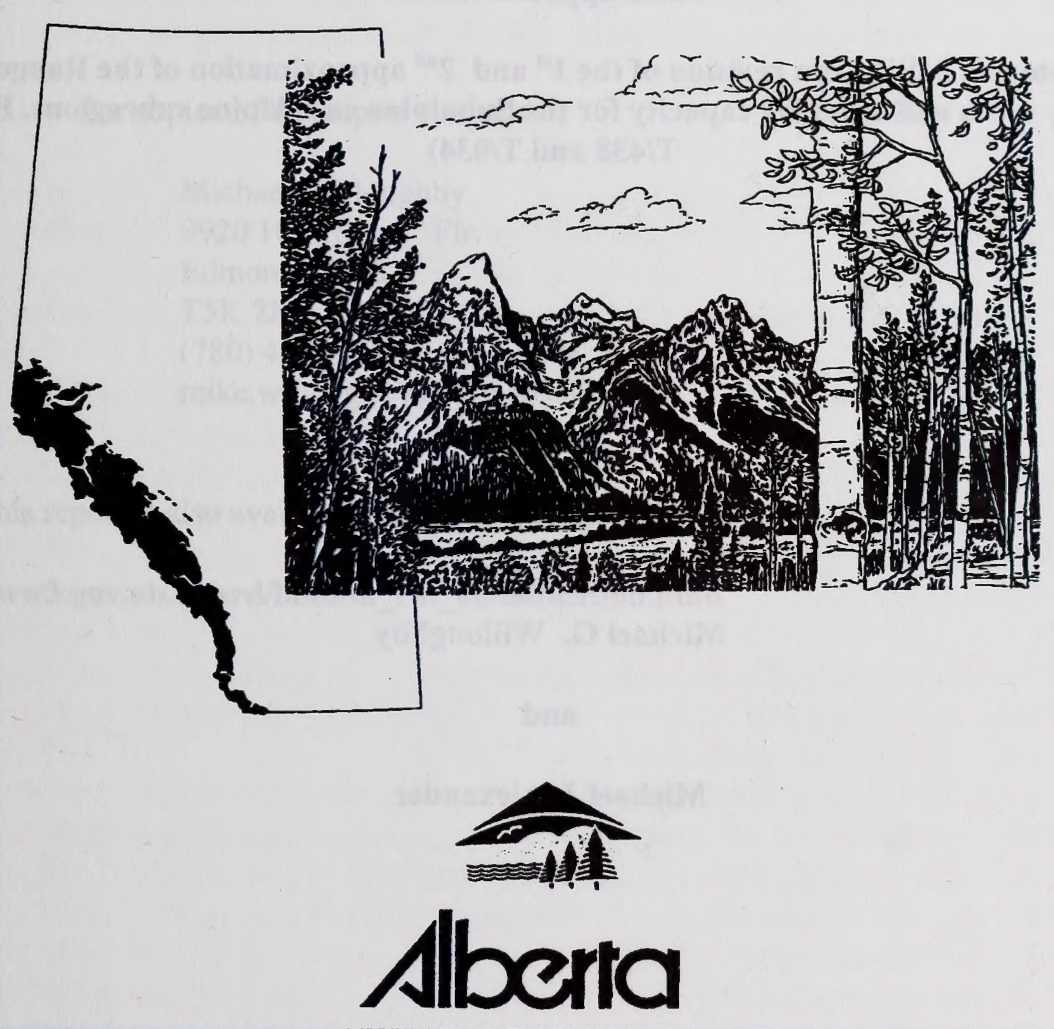

Sustainable Resource Development Public Lands and Forests Division 


\section{RANGE PLANT COMMUNITY TYPES AND CARRYING CAPACITY FOR THE SUBALPINE AND ALPINE SUBREGIONS}

\section{Third approximation}

(Please note this edition is a revision of the $1^{\text {st }}$ and $2^{\text {nd }}$ approximation of the Range Plant Community types and carrying capacity for the Subalpine and Alpine subregions. Pub. No. $T / 438$ and $T / 034)$

2006

Prepared by

Michael G. Willoughby

and

Michael J. Alexander

Edmonton

2006
Sustainable Resource Development

Public Lands and Forests Division 
Pub. No.: T/072

ISBN: 0-7785-4065-0 (Printed edition)

ISBN: 0-7785-4066-9 (On-line edition)

For copies of this report contact:

Michael Willoughby

$9920108^{\text {th }}$ Str. $4^{\text {th }}$ Flr.

Edmonton, $\mathrm{AB}$

T5K 2M4

(780) 422-4598

mike.willoughby@gov.ab.ca

This report is also available on-line at:

http://www3.gov.ab.ca/srd/land/m_rm_classification.html 
Introduction

Climate of Subalpine and Alpine subregions

Approach and Methods

Range Management Concepts

4

Ecologically sustainable stocking rates

Rangeland Health

How to use guide

Results

Subalpine (Grassland and Shrubland ecology)

Central and Northern Foothills areas

Ecology of ecodistricts

Key to grasslands in the Foothills

Key to shrublands in the Foothills

Grasslands

Community types

SACFA1. Water sedge-Beaked sedge meadows 37

SACFA2. Tufted bulrush $\quad 38$

SACFA3. Sedge-Cottongrass $\quad 39$

SACFA4. Tufted hairgrass-Sedge $\quad 40$

SACFA5. Sedge-Tufted hairgrass $\quad 41$

SACFA6. Sedge-Rocky Mtn. fescue-Alpine timothy 42

SACFA7. Sedge-Slender wheatgrass-Fringed brome/Forb 43

SACFA8. California oatgrass-Sedge 44

SACFA9. Rough fescue-Hairy wildrye-Sedge $\quad 45$

SACFA10. Sedge-Hairy wildrye $\quad 46$

SACFA11. Blunt sedge-Junegrass/Bearberry $\quad 47$

SACFA12. Fringed sage/Sedge-Junegrass $\quad 48$

SACFA13. Sedge-Bog sedge-Tufted hairgrass $\quad 49$

SACFA14. White Mtn. avens/Bog sedge 50

SACFA15. Creeping red fescue-Sedge 51

SACFA16. Kentucky bluegrass-Sedge/Dandelion 52

Shrublands

SACFA17. Fireweed-Meadow rue/Sedge-Hairy wildrye 53 
SACFB1. Willow-Bog birch/Water sedge $\quad 54$

SACFB2. Willow/Horsetail $\quad 55$

SACFB3. Willow/Graceful sedge $\quad 56$

SACFB4. Willow-Bog birch/Tufted hairgrass $\quad 57$

SACFB5. Willow-Bog birch/Clover-Dandelion 58

SACFB6. Willow-Bog birch/California oatgrass $\quad 59$

SACFB7. Willow-Bog birch/Hairy wildrye $\quad 60$

SACFB8. Bog birch/Bog sedge-Sedge 61

SACFB9. Bog birch-Willow/Rough fescue $\quad 62$

SACFB10. Bog birch/Rough fescue-Bog sedge 63

SACFB11. Willow/Fringed brome-Sedge $\quad 64$

$\begin{array}{ll}\text { Central and Northern Rocky Mountain areas } & 65\end{array}$

Ecology of ecodistricts $\quad 66$

Key to the grasslands within the Mountain ecodistricts $\quad 70$

Key to the shrublands within the Mountain ecodistricts 71

Grasslands

Community types

SACMA1. Bog sedge-California oatgrass $\quad 72$

SACMA2. Forb meadows $\quad 73$

SACMA3. Shrubby cinquefoil/Hairy wildrye $\quad 74$

SACMA4. Bearberry-Juniper $\quad 75$

SACMA5. Junegrass-Hairy wildrye-Brome $\quad 76$

SACMA6. Hairy wildrye/Bearberry-Juniper 77

SACMA7. Northern wheatgrass $\quad 78$

SACMA8. Alpine bluegrass $\quad 79$

Shrublands

SACMA9. Yellow mountain avens $\quad 80$

SACMB1. Willow/Water sedge $\quad 81$

SACMB2. Willow-Bog birch/Sedge $\quad 82$

SACMB3. Willow-Bog birch/Hairy wildrye $\quad 83$

$\begin{array}{lr}\text { SACMB4. Willow-Bog birch/Bog sedge } & 84\end{array}$

SACMB5. Bog birch/Juniper $\quad 85$

SACMB6. Willow/Forb $\quad 86$

$\begin{array}{ll}\text { SACMB7. Grouseberry-Juniper } & 87\end{array}$

SACMB8. Subalpine fir $\quad 88$

$\begin{array}{lr}\text { Southern Rocky Mountains } & 89\end{array}$

Native grass and shrubland ecology $\quad 90$

Key to grasslands and shrublands $\quad 124$

Grasslands

Community types 
North of Blairmore

SASMA1. Water sedge $\quad 126$

SASMA1a. Awned sedge-Alpine foxtail-Tufted hairgrass $\quad 127$

$\begin{array}{ll}\text { SASMA2. Rough fescue-Sedge } & 128\end{array}$

SASMA2a. Rough fescue-Richardson needlegrass $\quad 129$

SASMA3. Rough fescue-Hairy wildrye 130

SASMA3a Hairy wildrye-Rough fescue-Sedge 131

SASMA4. Sedge-Hairy wildrye-Slender wheatgrass 132

SASMA6. Yellow mountain avens 133

SASMA7. Tufted hairgrass-Sedge $\quad 134$

South of Blairmore

SASMA7a Marsh reedgrass/Cow parsnip $\quad 135$

SASMA8. Rough fescue-Idaho fescue-Parry oatgrass 136

SASMA9. Rough fescue-Sedge/Bearberry 137

SASMA10. Parry oatgrass-Rough fescue-Sedge 138

SASMA11. Sedge/Bearberry $\quad 139$

SASMA12. Silverberry-Rose $\quad 140$

SASMA13. Fescue-Junegrass/Early yellow locoweed 141

SASMA14. White Mountain avens $\quad 142$

SASMA15. Pinegrass-Hairy wildrye/Strawberry 143

$\begin{array}{ll}\text { SASMA16. Forb meadow } & 144\end{array}$

SASMA17. Bluebunch wheatgrass-Sedge $\quad 145$

Shrublands

SASMB1. Willow/Sedge $\quad 146$

$\begin{array}{ll}\text { SASMB2. Willow/Richardson needlegrass } & 147\end{array}$

$\begin{array}{ll}\text { SASMB3. Whitebark pine } & 148\end{array}$

SASMB4. Willow-Bog birch/Rough fescue-Kentucky bluegrass $\quad 149$

SASMB5. Willow/Marsh reedgrass $\quad 150$

SASMB6. Smooth willow-Shrubby cinquefoil/Hairy wildrye 151

SASMB7. Smooth willow-Juniper/Hairy wildrye 152

SASMB8. Willow/Tufted hairgrass-Kentucky bluegrass 153

$\begin{array}{ll}\text { SASMB9. Bebb willow pinegrass } & 154\end{array}$

Grazing modified

SASMC1. Parry oatgrass-Rough fescue-Kentucky bluegrass $\quad 155$

SASMC2. Parry oatgrass-Kentucky bluegrass-Sedge 156

$\begin{array}{ll}\text { SASMC3. Meadow foxtail-Kentucky bluegrass } & 157\end{array}$

SASMC4. Fringed sage/Kentucky bluegrass-Parry oatgrass $\quad 158$

SASMC5. Rough fescue-Kentucky bluegrass $\quad 159$

SASMA5. Kentucky bluegrass/Dandelion $\quad 160$

SASMC6. Kentucky bluegrass-Rough fescue 161

SASMC7. Timothy-Slender wheatgrass/Fireweed 162

SASMC8. Marsh reedgrass-Timothy/Cow parsnip 163 
SASMC9. Idaho fescue-Rough fescue/Bearberry 164

SASMC10. Tufted hairgrass-Kentucky bluegrass 165

SASMC11. Creeping red fescue/Clover 166

SASMC12. Rose/Pinegrass $\quad 167$

SASMC13. Idaho fescue-Sheep fescue-Canada bluegrass 168

$\begin{array}{ll}\text { Subalpine Forest Ecology } & 170\end{array}$

Deciduous

$\begin{array}{ll}\text { SASMD1 Pb/Silverberry } & 172\end{array}$

SASMD2. Aw/Rose/Pinegrass 173

SASMD3. Aw/Fireweed/Meadow foxtail $\quad 174$

SASMD4. Aw/Rose/Canada bluegrass $\quad 175$

SASMD5. Aw- $\mathrm{Pb} /$ Cow parsnip $\quad 176$

SASMD6. Aw-Pb/Cow parsnip/Timothy 177

SASMD7. Pb/Willow/Marsh reedgrass 178

$\begin{array}{ll}\text { SASMD8. Aw/Kentucky bluegrass/Clover } & 179\end{array}$

SASMD9. Aw/Rose/Marsh reedgrass $\quad 180$

SASMD10. Aw/Bearberry-Juniper 181

Conifer

$\begin{array}{ll}\text { SASME1. P1/Juniper } & 182\end{array}$

SASME2. Pl/Pinegrass $\quad 183$

SASME3. Pl-Se/Moss $\quad 184$

SASME4. Se-Aw/Alder/Hairy wildrye $\quad 185$

SASME5. Sw/Willow-Labrador tea 186

$\begin{array}{ll}\text { Cutblocks } & 187\end{array}$

Ecology of cutblocks $\quad 188$

SASMF1 Pinegrass/Fireweed/Sw 189

Alpine subregion

Ecology of Alpine communities 191

Community types

ALPA1. Bog sedge $\quad 205$

ALPA2. White mountain avens 206

ALPA3. Mountain heather 207

ALPA4. Blackening sedge 208

ALPA5. Simple bog sedge $\quad 209$

ALPA6. Arctic willow (low willow types) 210

ALPA7. Lichen stonefields 211 


\section{List of Figures}

Figure 1. Edatopic grid for the Central and Northern Foothills and Central and Northern Mountains of the Subalpine subregion.

Figure 2. Overview of native shrub and grassland complex in the Central and Northern Foothills

Figure 3. Grassland and shrubland community types in the landscape of the Central and

Northern Rocky Mountain and Foothills areas of the Subalpine subregion

Figure 4. Overview of native shrub and grassland complex in the Central and Northern Rocky Mountains

Figure 5. Sequence of plant communities in the upper Subalpine and Alpine subregions of Alberta

69

Figure 6. Overview of native shrub and grassland complex in the Southern Rocky

Mountains

Figure 7. Grassland and shrubland community types in the landscape of the Montane and

Subalpine subregions of southern Alberta

123

Figure 8. Aspen/Rose/Pinegrass dominated community type in the southern zone of the

Subalpine subregion

Figure 9. Overview of native shrub and grassland complex in the Alpine subregion

\section{List of Tables}

Table 1. Ecological sites, ecological range sites and plant community types for the Subalpine subregion of West-Central Alberta(adapted from Beckingham et al. 1996).

Table 2. Native grass and shrublands of the Central and Northern Foothills

Table 3. Native grass and shrublands of the Central and Northern Rocky Mountains

Table 4. Ecological sites, ecological site phases and plant community types for the Subalpine subregion of Southern Alberta(adapted from Archibald and Klappstein 1996). 91

Table 5. Native grass and shrublands of the Southern Rocky Mountains

Table 6. Deciduous and conifer communities for the Southern Rocky Mtn. ecodistrict of the Subalpine subregion 
Table 8. Ecological sites, ecological site phases and plant community types for the Alpine subregion.

Table 9. Native grasslands and shrublands of the Alpine subregion

\section{List of Maps}

Map 1. Location of Alpine and Subalpine subregions in Alberta 


\begin{abstract}
The Subalpine subregion is a Rocky Mountain altitudinal vegetation zone extending from an elevation of $1575 \mathrm{~m}$ to $2175 \mathrm{~m}$ at its southernmost occurrence and $1365 \mathrm{~m}$ to $2000 \mathrm{~m}$ near Grande Cache (Strong 1992). The valley bottoms of the subalpine are extensively utilized for recreational horseback riding and commercial trail riding operations. As a result many of the grass and shrublands around the back country campsites are extensively utilized by horses. This utilization has an impact on the vegetation which can be detrimental to the wildlife populations in the area. In the southern part of the province (south and west of Calgary) extensive areas of the subalpine is also provide forage for cattle. Despite the importance of these vegetation types for wildlife and livestock use there is little information on their ecology. The lack of information makes it difficult to develop management prescriptions for multiple use. The Alpine subregion which occurs above the upper climatic forest-line in the Rocky Mountains (Strong 1992) overlaps with many of the subalpine community types and therefore can be important locally for wildlife. As a result this guide was developed for the Subalpine and Alpine subregions in order to provide a framework that will easily group the vegetative community types. It is hoped this classification system can be used by field staff to assess the ecology of the sites and develop management prescriptions on lands within each region. This guide represents the analysis of 704 plots described in the Subalpine subregion and 134 grass and shrubland plots described in the Alpine subregion. In the Subalpine subregion it was found there was distinct differences between the grassland and shrubland community types between the Central and Northern Foothills (West of Rocky Mountain house and Hinton), the Central and Northern Rocky Mountains (Banff and Jasper National Parks) and the Southern Rocky Mountains (southwest of Calgary). As a result the Subalpine was prestratified into 3 subdivisions. These types are split into:
\end{abstract}

\title{
Subalpine
}

Central and Northern Foothills
A. Native grasslands
B. Native shrublands
17 community types
11 community types

Central and Northern Rocky Mountains
A Native grasslands
B. Native shrublands
9 community types
8 community types

Southern Rocky Mountains
A. Native grasslands
20 community types
B. Native shrublands
C. Grazed grasslands
9 community types
D. Deciduous
14 community types
E. Conifer
10 community types
F. Cutblocks
5 community types
1 community type

Alpine

A. Native grasslands and shrublands 7 community types

The dominant plant species, canopy cover, environmental conditions, response to grazing, forage production and carrying capacity are outlined for each type. 


\section{Acknowledgements}

The creation of this report would not be possible without the data collected in other projects. We would like to acknowledge Parks Canada for allowing us to use data from the Ecological Land Classification of Banff and Jasper National Parks (Holland and Coen 1982). Much of the grass and shrubland vegetation data collected by Ian Corns and Peter Achuff for this project were incorporated into this guide. We would also like to acknowledge the Alberta Conservation Association and Corporate Management Service. They provided funding for the study of bighorn sheep winter range in Southern Alberta and backcountry horse use and elk carrying capacity in the Panther Corners. The vegetation data from these studies were also included in this guide. Finally appreciation and thanks go out to all members and former members of Land and Forest Service who were involved in data collection. 


\section{Introduction}

The province of Alberta is covered by a broad spectrum of vegetation regions from prairie in the South, to alpine vegetation in the mountains and dense forests in the Central and Northern part of the province. These broad vegetation regions have been classified into 6 regions and 20 subregions (Dept. of Environmental Protection 1994). Each of the 20 subregions consists of groups of ecological sites and plant communities which are influenced by environmental conditions and human impacts. Ecological sites are complex and evolving systems, with a flow of energy and matter, which is influenced by the interaction of climate, landforms, soils, vegetation and animals (Archibald et al. 1996). Intensive management of these ecological sites requires the ability to recognize and classify the vegetative communities that have similar productivities and respond to disturbance in the same way.

The purpose of this guide was to develop a framework that would easily group the grassland and shrubland community types in the Subalpine and Alpine subregions of the province. It is hoped this classification system can be used by field staff to assess the ecology of the sites and develop management prescriptions on lands within the region. This guide supplements the work done by Beckingham et al. (1996), Beckingham and Archibald (1996) and Archibald et al. (1996) on the forested community types in the Subalpine subregion and follows their classification hierarchy (ecosite, ecosite phase, plant community), but uses different terminology in an effort to be consistent with historic rangeland classification systems. Their guides are a good description of the forested community types found within the subregions, but it does not include forage production values and stocking rates. It also does not provide a description of the native shrubland and grassland communities which are utilized by livestock and horses at the lower elevations in this subregion.

\section{Climate}

\section{Subalpine subregion}

The subalpine subregion is a Rocky Mountain altitudinal vegetation zone with its upper boundary formed by the Alpine subregion, whereas the lower boundary abuts the Montane, Foothills parkland and the Upper Foothills subregions. In Alberta, the subalpine extends from $1525 \mathrm{~m}$ to $2175 \mathrm{~m}$ at its southernmost occurrence and from $1360 \mathrm{~m}$ to $2000 \mathrm{~m}$ in the vicinity of Grande Cache (Strong 1992). The subalpine has a cordilleran climate characterized by snowy, cold winters and showery cool summers. Annual precipitation ranges from $329 \mathrm{~mm}$ to $916 \mathrm{~mm}$, with maximum precipitation falling during July. The subalpine receives more precipiatiton during the winter months than any subregion (Strong 1992). The mean summer temperatures averages $9.4{ }^{\circ} \mathrm{C}$ and winter temperatures typically average $-8.9^{\circ} \mathrm{C}$ with December and January being the coldest months. The cold winter temperatures help to maintain the snowpack which makes this an important watershed area.

The majority of the vegetation is dominated by seral lodgepole pine forests at lower elevations with Engelmann spruce and subalpine fir forests being more common at higher elevations. At timberline dwarf spruce, subalpine and whitebark pine are typical of the transition 
to the Alpine subregion. Imperfectly drained bottomlands are dominated by willow, bog birch, sedge, tufted hairgrass and california oatgrass species and the steep south facing slopes are often dominated by fescue, hairy wildrye, wheatgrass and junegrass species.

\section{Alpine subregion}

The Alpine subregion occurs above timberline in the Rocky Mountains of Alberta. Elevationally, alpine occupies areas greater than $2150 \mathrm{~m}$ in southern Alberta and declines to $2000 \mathrm{~m}$ in more northern portions. It is felt that the total annual precipitation is at least equal to the Subalpine subregion, which potentially makes the Alpine the wettest subregion in Alberta (Strong 1992). Summer temperatures are the coldest in Alberta with July mean temperatures averaging $10{ }^{\circ} \mathrm{C}$. Freezing temperatures occur in all months of the year. Winter temperatures are probably colder than the subalpine subregion with temperatures probably never going above freezing for the whole winter. The cold temperatures help to maintain the snowpack for much of the year. Wind is also extremely important climatic factor in the Alpine. Although, precipitation is abundant the strong winds likely result in very large moisture deficits (Strong 1992).

The Alpine is characterized by low growing vegetation, which helps to protect the vegetation from the dessicating winds, and allows the plants to gain heat from the ground. Glaciers occur at the higher elevations where snow accumulation exceeds melt. 


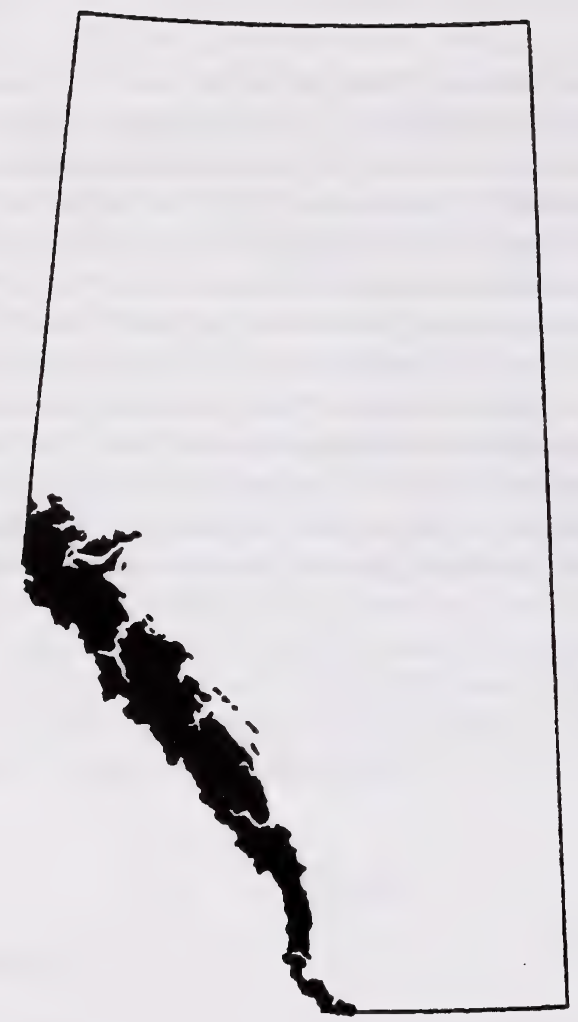

Map 1. Location of Subalpine and Alpine subregions in Alberta 


\section{Approach and Methods of Classification}

\section{Approach: Ecological classification hierarchy and terminology}

The system of classification in this guide was initially based on the community type approach of Mueggler (1988). Mueggler's system was chosen over the habitat type approach (Daubenmire 1952) or ecosystem association approach (Corns and Annas 1986) because it could classify plant communities irregardless of their successional status. However, as the philosophy of rangeland health and proper functioning condition of a site evolved, it became apparent (through data analysis) that there was a need to also organize the various plant communities based on their response to disturbance (i.e. disturbance vs. natural succession) within an area under similar environmental influences.

It was determined that the ecosystem classification system developed by Corns and Annas (1986) and Beckingham et al. (1996) could accommodate this additional requirement. Thus, the new system developed for rangelands is a combination of Mueggler (1988) and Beckingham et al. (1996). Consequently, this guide adopts a similar ecological unit classification hierarchy (ecosite, ecosite phase, plant community). In an effort to first, link the hierarchical system with the historic rangeland system, and second, to create a provincially standardized rangeland approach, slightly different classification terminology was developed. The new terms ecological site and ecological site phase (replacing Beckingham et al.'s [1996] ecosite and ecosite phase terms respectively), provide subtle distinction to recognize the blending of the old systems and still be recognizable to readers familiar with the original terminology

\section{Methods: Plant community classification}

Sampling for this guide occurred within the Subalpine and Alpine subregions. This guide represents the analysis of 704 plots described in the Subalpine subregion and 134 grass and shrubland plots described in the Alpine subregion. The procedure for inventory of plots followed the Range Survey Manual (1992) and uses the MF5 form. A plot consisted of a $10 \mathrm{~m} \mathrm{x}$ $10 \mathrm{~m}$ macroplot and ten randomly selected $1 \mathrm{~m} \mathrm{x} 1 \mathrm{~m}$ microplots to record the canopy cover of shrubs and ten nested $20 \mathrm{~cm} \times 50 \mathrm{~cm}$ microplots to record the canopy cover of forbs and grass. The data for each site was analyzed using the multivariate analysis techniques of classification and ordination. Classification is the assignment of samples to classes or groups based on the similarity of species. A polythetic agglomerative approach was used to group the samples. This technique assigns each sample to a cluster which has a single measure. It then agglomerates these clusters into a hierarchy of larger and larger clusters until finally a single cluster contains all the samples (Gauch 1982). Cluster analysis was performed in SAS and Euclidean distance was used as the Cluster Distance Measure and Ward's method was used in the Group Linkage Method. The groupings generated in cluster analysis were overlain on the site ordination to determine final groupings. Ordination was used to find relationships among species, communities and environmental variables. Ordination reduces the dimensionality of the data to 1-3 most important axes to which environmental gradients can be assigned. The ordination 
technique used in the analysis of the data was DECORANA (Detrended Correspondence Analysis). DECORANA detrends and rescales the axes thereby reducing the arching and compression of axes problems associated with other ordination techniques (Reciprocal averaging, Principle Components Analysis). Once final groupings were determined on the ordination specific environmental variables can be assigned to the variation outlined on the ordination axes.

Plant community type summaries were generated in SAS, by averaging plant species composition, range in composition, and percent constancy of occurrence, among vegetation inventory plots which were part of a community type. Environmental data was subsequently sorted into the same plant community groupings to create the plant community descriptions outlined in this guide. The number of sample plots on which the description was based is also provided (e.g. $\mathrm{n}=16$ ).

\section{Range Management Concepts and Methods}

\section{Ecologically sustainable stocking rates}

Ecologically sustainable stocking rates (ESSR) values are suggested for each plant community. These values reflect the maximum number of livestock (e.g. hectares(ha)/animal unit month(AUM)) that can be supported by the plant community given inherent biophysical constraints and the ecological goal of sustainable health and proper functioning of the plant community. When the ESSR is multiplied by the area (e.g. ha) of a plant community polygon the result is termed ecologically sustainable carrying capacity (ESCC), and is expressed as AUMs. Often the ESCC must be adjusted for management factors (e.g. reduced livestock distribution), management goals (e.g. improve rangeland health, multiple use and values, etc.), drought conditions, and other natural phenomena impacting the site (e.g. forage quality, fire, pests, etc.). This adjusted/reduced value is the ecologically sustainable grazing capacity (ESGC). The ESGC values are not provided in the plant community guide because the necessary adjustments are determined by the rangeland resource manager.

Suggested ESSR values were determined from a combination of clipping studies, longterm rangeland reference area data, estimated production, range health trends and historical grazing experience. In order to sustain ecological health and function of the plant community, the ESSR has been established by the resource manager and is based on the ecological, climatic and seasonal conditions for each community type. In determining ESSR the forage requirements for one Animal Unit (AU) has been set at $455 \mathrm{~kg}$ of dry matter per month. The remaining biomass production (carry over), is allocated for the maintenance of ecological functions (e.g. nutrient cycling, viable diverse plant communities, hydrological function, and soil protection, etc.) and plant community services (forage production, habitat maintenance, etc.). The allocation of biomass production in this manor is well established, and supported, by the scientific community and the amount required, varies with Natural Subregion (Holechek et al. 1995). 


\section{Rangeland Health}

Range health is determined by comparing the functioning of ecological processes on an area (e.g. plant community polygon) of rangeland to a standard (i.e. RPC) described within an ecological site description. An ecological site is similar to the concept of range site, but a broader list of characteristics are described. An ecological site is defined by the Task Group on Unity and Concepts (1995) as, "a distinctive kind of land with specific physical characteristics that differs from other kinds of land in its ability to produce a distinctive kind and amount of vegetation". This guide can be used to determine the appropriate reference range plant community, within an ecological site, for a rangeland health assessment.

Rangeland health assessments are utilized to make a rapid determination of the ecological status of rangeland. We use range health terminology (healthy, healthy with problems, or unhealthy), to rank the ability of rangeland to perform certain ecological functions. These functions include: net primary production, maintenance of soil/site stability, capture and beneficial release of water, nutrient and energy cycling and plant species functional diversity. For a detailed description on how to assess rangeland health for various plant communities please refer to "Rangeland Health Assessment for Grassland, Forest and Tame Pasture" (Adams et al. 2003). A general range health category (Healthy, Healthy with problems, Unhealthy) has been added to each community type description, which can be used as a guide when doing range health assessments.

Range management objectives tend to favor the later stages of plant succession (lateseral to potential natural community (PNC) or good to excellent range condition) (Adams et al. 2003). Late seral plant communities tend to be superior in the efficient capture of solar energy, in cycling of organic matter and nutrients, in retaining moisture, in supporting wildlife habitat values and in providing the highest potential productivity for the site. In contrast, early seral stages represent plant communities with diminished ecological processes, which are less stable and more vulnerable to erosion and invasion by weeds and non-native species. They also have diminished resource values for livestock forage production, wildlife habitat and watershed protection (Adams et al. 2003). Healthy rangelands perform important ecological functions and provide a broader suite of goods and services. In most cases these late seral plant communities are used as reference range plant community (RPC), but sometimes management goals influence the choice of RPC (e.g. a cut block to be maintained as untimbered rangeland).

\section{How to use the guide}

In the Subalpine subregion it was found there was distinct differences between the grassland and shrubland community types between the Central and Northern Foothills (the foothills west of Sundre, Rocky Mtn. House, Hinton and Grande Cache), the Central and Northern Rocky Mountains (mountains of Banff and Jasper National Park) and the Southern Rocky Mountains (foothills west of Calgary, Turner valley and areas south of Blairmore) (Strong and Thompson 1995). As a result the Subalpine was prestratified into 3 subdivisions. For the Subalpine first decide which area you are in then turn to the appropriate subdivision in the guide. The Alpine is generally all the vegetation types above timberline. 
The plant community types in this guide were organized into the hierarchial ecosite and ecosite phase classification outlined in "Ecosites of West-Central Alberta and Southwestern Alberta" (Beckingham et al. 1996, Archibald et al. 1996), the community types in this guide are arranged by ecological sites (ecosite) and ecological site phase (ecosite phase) for West-Central Alberta (Table 1) and Southwestern Alberta (Table 4). Ecological sites are defined as ecological units that develop under similar environmental influences (climate, moisture and nutrient regime). An Ecological Site Phase is a subdivision of the ecological site based on the dominant species in the canopy. Table 1 is a reproduction of Figure 20 in the Ecosites of West-Central Alberta guide and table 4 is a reproduction of Figure 20 in the Ecosites of Southwestern Alberta guide with the community types in this guide highlighted. For the most part the ecological sites (ecosites) and ecological site phases (ecosite phases) are the same, particularly for the forested community types, but a number of new ecological sites and ecological site phases had to be created for the grass and shrubland community types (Table 1). The ecological sites include (bb)(subxeric/poor) yellow mountain avens, and (dd)(subhygric/medium) bog sedge meadow. The ecological site phases include (b2) bearberry grassland, (bb1) yellow mtn. avens, (c4) hairy wildrye grassland, (d4) California oatgrass, (d5) willow, (d6) grouseberry, (dd1) sedge-bog sedge, (dd2) shrubland, (e3) grass meadow, (g2) willow and (h3) grass bog for West-Central Alberta (Table 1). In Southwestern Alberta the new ecological sites include (cc) (submesic/rich) rough fescue, and (i) fen. The ecological site phases included (a2) grassland, (b2) grassland, (b4) bearberry-Aw, (c2) yellow mtn. avens, (cc1) rough fescue, (cc2) shrubland, (cc3) forb meadow, (e7) shrubland, (f3) thimbleberry Aw, (f4) shrubby seepages, (i1)shrub fen, (i2) graminoid fen and (i3) treed fen (Table 4). The "Successional Community Types" category outlines the successional sequence the community type will undergo with increased grazing pressure. For a detailed description of the forested community types in the Subalpine please refer to the work done by Beckingham et al. (1996), Beckingham and Archibald (1996) and Archibald et al. (1996). The dominant plant species, canopy cover, environmental conditions, response to grazing, forage production and carrying capacity of the grasslands and shrublands for the Subalpine and Alpine subregions are outlined in this guide. 
Table 1. Ecological site, ecological site phases and community types for the Subalpine subregion of West-Central Alberta (adapted from Beckingham et al. 1996)(Reference range plant community types are described in this guide, Forested plant communities are outlined in guide to Ecosites of West-Central Alberta)

\begin{tabular}{|c|c|c|c|c|c|}
\hline $\begin{array}{l}\text { Ecological } \\
\text { Site }\end{array}$ & $\begin{array}{l}\text { Ecological } \\
\text { Site Phase }\end{array}$ & & $\begin{array}{c}\text { Forested Plant Community } \\
\text { Type }\end{array}$ & $\begin{array}{c}\text { Reference Range Plant } \\
\text { Community }\end{array}$ & $\begin{array}{l}\text { Successional } \\
\text { Community } \\
\text { Types }\end{array}$ \\
\hline \multirow{3}{*}{$\begin{array}{c}\text { a grassland } \\
\text { (subxeric/medium) }\end{array}$} & \multirow[t]{2}{*}{ al al shrubby grassland } & a1.1 & bearberry grassland & SACFA11 Blunt sedge-Junegrass/Bearberr & \\
\hline & & a1.2 & willow-dwarf birch grassland & SACMB5 Bog birch/Juniper & \\
\hline & a2 graminoid grassland & a2.1 & $\begin{array}{l}\text { Bellard's kobresia-hairy wild rye } \\
\text { grassland }\end{array}$ & $\begin{array}{l}\text { SACFA14. White Mtn. Avens/Bog sedge } \\
\text { SACMA7 Northern wheatgrass } \\
\text { SACFA10 Sedge-Hairy wildrye } \\
\text { SACFA12 Fringed sage/Sedge-Junegrass }\end{array}$ & \\
\hline \multirow{4}{*}{$\begin{array}{l}\text { b bearberry/lichen } \\
\text { (subxeric/poor) }\end{array}$} & \multirow[t]{3}{*}{ b1 bearberry/lichen $\mathrm{P} 1$} & b1.1 & P1/bearberry/lichen & & \\
\hline & & b1.2 & P1/bog cranberry/lichen & & \\
\hline & & b1.3 & P1/crowberry/lichen & & \\
\hline & b2 bearberry grassland & & & SACMA4 Bearberry -Juniper & \\
\hline $\begin{array}{l}\text { bb yellow mtn. avens } \\
\text { (submesic/poor) }\end{array}$ & bb1 yellow mtn. avens & & & SACMA9 Yellow Mountain avens & \\
\hline \multirow[t]{2}{*}{$\begin{array}{l}\text { c hairy wild rye } \\
\text { (submesic/medium) }\end{array}$} & \multirow[t]{2}{*}{ cl hairy wild rye P1 } & $\mathrm{cl} .1$ & $\begin{array}{l}\text { P1/Canada buffalo-berry/hairy wild } \\
\text { rye }\end{array}$ & & \\
\hline & & $\mathrm{c} 1.2$ & P1/juniper-bearberry/hairy wild rye & & \\
\hline
\end{tabular}




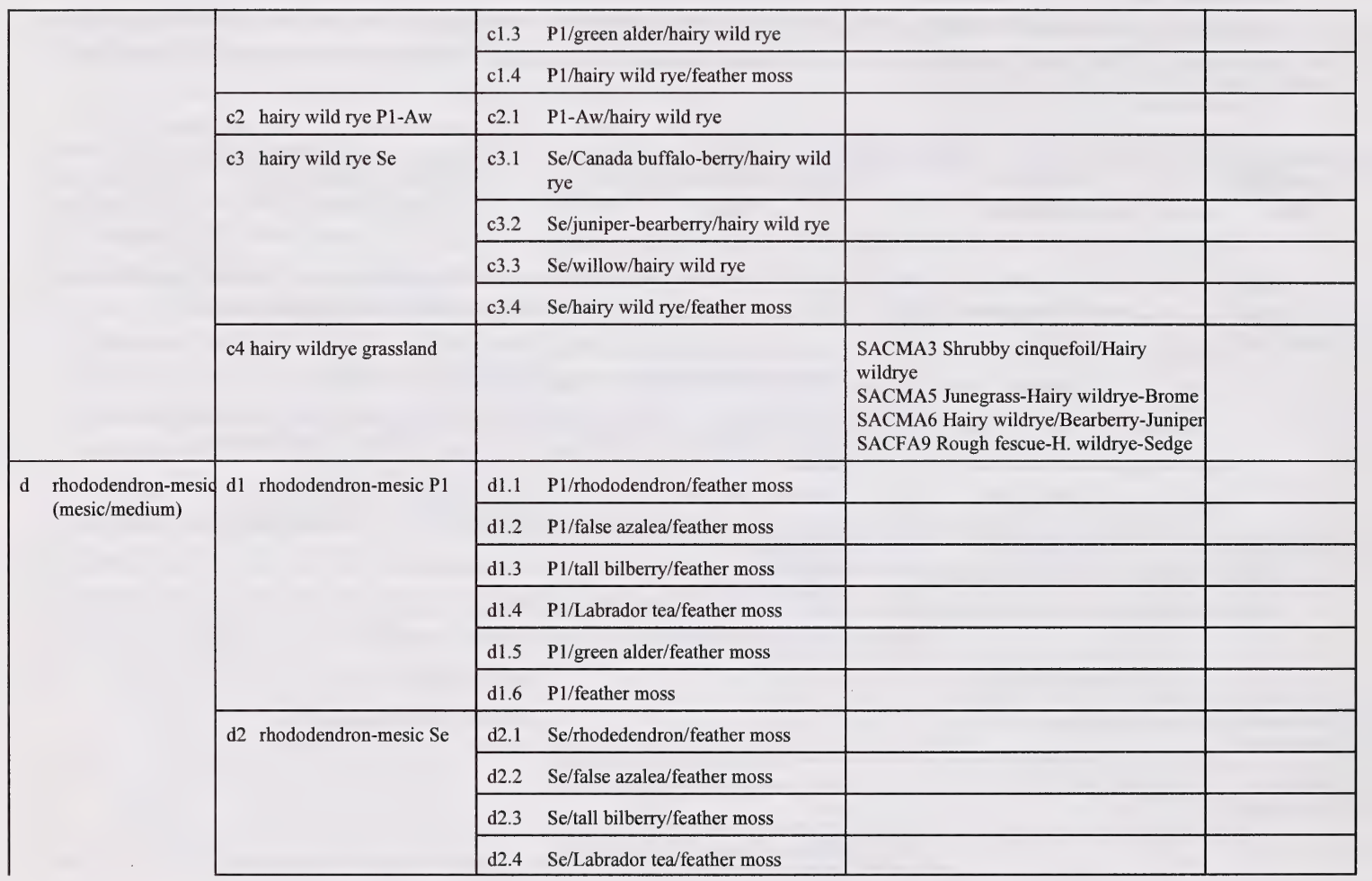




\begin{tabular}{|c|c|c|c|c|c|}
\hline & & $\mathrm{d} 2.5$ & Se/green alder/feather moss & & \\
\hline & & d2.6 & $\mathrm{Se} /$ subalpine fir/feather moss & & \\
\hline & & $\mathrm{d} 2.7$ & Se/feather moss & & \\
\hline & $\mathrm{d} 3$ rhododendron-mesic $\mathrm{Fa}$ & $\mathrm{d} 3.1$ & $\mathrm{Fa} /$ rhododendron/feather moss & & \\
\hline & & $\mathrm{d} 3.2$ & $\mathrm{Fa} /$ false azalea/feather moss & & \\
\hline & & $\mathrm{d} 3.3$ & $\mathrm{Fa} /$ tall bilberry/feather moss & & \\
\hline & & d3.4 & $\mathrm{Fa} /$ subalpine fir/feather moss & & \\
\hline & & $\mathrm{d} 3.5$ & $\mathrm{Fa} /$ feather moss & SACMB8 Subalpine fir & \\
\hline & d4 California oatgrass & & & $\begin{array}{l}\text { SACFA8 California oatgrass-Sedge } \\
\text { SACMA1 Bog sedge-California oatgrass } \\
\text { SACMA8 Alpine bluegrass }\end{array}$ & \\
\hline & d5 Willow & & & $\begin{array}{l}\text { SACFB6 Willow-Bog birch/California } \\
\text { oatgrass }\end{array}$ & \\
\hline & d6 grouseberry & & & SACMB7 Grouseberry-Juniper & \\
\hline $\begin{array}{l}\text { dd bog sedge meadow } \\
\text { (subhygric/medium) }\end{array}$ & dd1 sedge-bog sedge & & & $\begin{array}{l}\text { SACFA13 Sedge-Bog sedge-Tufted } \\
\text { hairgrass }\end{array}$ & \\
\hline & dd2 shrubland & & & $\begin{array}{l}\text { SACFB8 Willow-Bog birch/Bog sedge- } \\
\text { Sedge } \\
\text { SACFB9 Bog birch-Willow/Rough fescue } \\
\text { SACFB10 Bog birch/Rough fescue-Bog } \\
\text { sedge } \\
\text { SACMB4 Willow-Bog birch/Bog sedge }\end{array}$ & \\
\hline
\end{tabular}




\begin{tabular}{|c|c|c|c|c|c|}
\hline \multirow[t]{3}{*}{$\begin{array}{l}\text { e meadow } \\
\text { (subhygric/very } \\
\text { rich) }\end{array}$} & el shrubby meadow & e1.1 & willow-dwarf birch meadow & $\begin{array}{l}\text { SACFB3 Willow/Graceful sedge } \\
\text { SACFB4 Willow-Bog birch/Tufted } \\
\text { hairgrass } \\
\text { SACFB7 Willow-Bog birch/Hairy wildrye } \\
\text { SACFB11 Willow/Fringed brome-Sedge } \\
\text { SACMB2 Willow/Sedge } \\
\text { SACMB3 Willow-Bog birch/Hairy wildrye } \\
\text { SACMB6 Willow/Forb }\end{array}$ & $\begin{array}{l}\text { SACFB5 Willow } \\
\text { Bog birch/Clover } \\
\text { Dandelion }\end{array}$ \\
\hline & e2 forb meadow & e 2.1 & meadow rue meadow & SACMA2 Forb meadows & \\
\hline & e3 grass meadow & & & $\begin{array}{l}\text { SACFA4 Tufted hairgrass-Sedge } \\
\text { SACFA17 Fireweed-Meadow rue/Sedge-H } \\
\text { wildrye }\end{array}$ & $\begin{array}{l}\text { SACFA5 Sedge- } \\
\text { Tufted hairgrass } \\
\text { SACFA6 Sedge- } \\
\text { Rocky Mtn. } \\
\text { fescue-Alpine } \\
\text { timothy } \\
\text { SACFA7 Sedge- } \\
\text { Slender } \\
\text { wheatgrass- } \\
\text { Fringed } \\
\text { brome/Forb } \\
\text { SACFA16 } \\
\text { Kentucky } \\
\text { bluegrass- } \\
\text { Sedge/Dandelion } \\
\text { SACFA15 } \\
\text { Creeping red } \\
\text { fescue-Sedge }\end{array}$ \\
\hline \multirow{3}{*}{$\begin{array}{l}\text { f rhododendron- } \\
\text { subhygric } \\
\text { (subhygric/medium) }\end{array}$} & \multirow{3}{*}{$\begin{array}{l}\text { f1 rhododendron-subhygric } \\
\text { P1 }\end{array}$} & f1.1 & P1/rhododendron/feather moss & & \\
\hline & & f1.2 & P1 false azalea/feather moss & & \\
\hline & & f1.3 & P1/Labrador tea/feather moss & & \\
\hline
\end{tabular}




\begin{tabular}{|c|c|c|c|c|c|c|}
\hline & & f2 rhododendron-subhygric & $\mathrm{f} 2.1$ & $\mathrm{Se}-\mathrm{Fa} /$ rhododendron/feather moss & & \\
\hline & & & $\mathrm{f} 2.2$ & $\mathrm{Se}-\mathrm{Fa} /$ false azalea/feather moss & & \\
\hline & & & $\mathrm{f} 2.3$ & Se-Fa/Labrador tea/feather moss & & \\
\hline $\mathrm{g}$ & horsetail & g1 horsetail Se & $\mathrm{g} 1.1$ & Se/willow/horsetail & & \\
\hline & & & $\mathrm{g} 1.2$ & Se/feather moss & & \\
\hline & & g2 willow & & & SACFB2 Willow/Horsetail & \\
\hline $\mathrm{h}$ & $\begin{array}{l}\text { bog } \\
\text { (subhydric/poor) }\end{array}$ & h1 treed bog & h1.1 & $\begin{array}{l}\mathrm{Sb} / \text { cloudberry/feather moss-peat } \\
\text { moss }\end{array}$ & & \\
\hline & & h2 shrubby bog & h2.1 & Labrador tea/cloudberry/peat moss & & \\
\hline & & $\mathrm{h} 3$ grass bog & & & $\begin{array}{l}\text { SACFA2. Tufted bulrush } \\
\text { SACFA3. Sedge-Cottongrass }\end{array}$ & \\
\hline $\mathrm{i}$ & fen & il treed fen & i1.1 & $\mathrm{Sb}-\mathrm{Se} /$ willow/sedge/peat moss & & \\
\hline & & & i1.2 & $\begin{array}{l}\mathrm{Sb}-\mathrm{Se} / \text { willow-dwarf } \\
\text { birch/sedge/golden moss }\end{array}$ & & \\
\hline & & i2 shrubby fen & i2.1 & willow/sedge/tufted moss-peat moss & $\begin{array}{l}\text { SACFB1 Willow-Bog birch/Water sedge } \\
\text { SACMB1 Willow/Water sedge }\end{array}$ & \\
\hline & & & $\mathrm{i} 2.2$ & $\begin{array}{l}\text { willow-dwarf birch/sedge/peat moss- } \\
\text { golden moss }\end{array}$ & & \\
\hline & & & i2.3 & $\begin{array}{l}\text { dwarf birch/sedge/peat moss-golden } \\
\text { moss }\end{array}$ & & \\
\hline & & i3 graminoid fen & i3.1 & sedge fen & SACFA1. Water sedge-Beaked sedge & \\
\hline
\end{tabular}


Figure 1. Edatopic grid for the Central and Northern Foothills and Central and Northern Mountains of the Subalpine subregion.

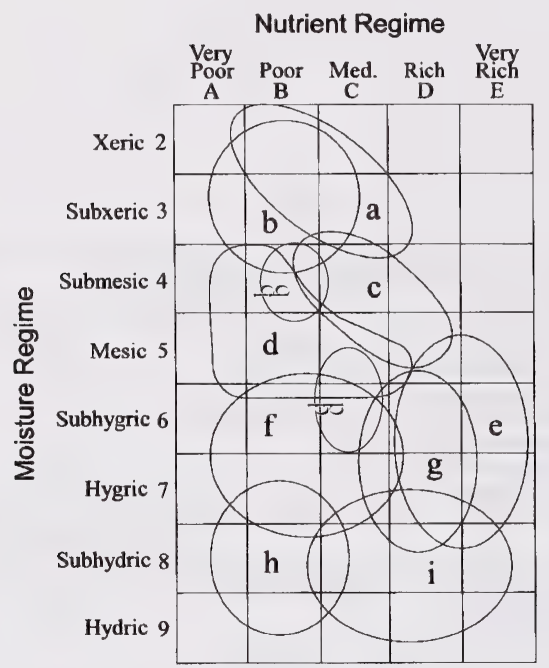

\section{Ecological sites}

a grassland

(subxeric/medium)

b bearberry/lichen

(subxeric/poor)

bb yellow mtn. avens

(submesic/poor)

c hairy wildrye

(submesic/medium)

d rhododendron-mesic

(mesic/medium)

dd bog sedge meadow

(subhygric/medium)

\section{e meadow}

(subhygric/very rich)

f rhododendron-subhygric

(subhygric/medium)

g horsetail

(hygric/rich)

h bog

(subhydric/poor)

i fen

(subhydric/rich) 


\section{b2 bearberry grassland $(n=14)$}

\section{CHARACTERISTIC SPECIES}

Trees

[2] Aspen

\section{Shrubs}

[2] Willow

[2] White mtn. avens

[3] Shrubby cinquefoil

[9] Ground juniper

Forbs

[19] Bearberry

[1] White camas

[1] Strawberry

[1] Yarrow

\section{Graminoids}

[1] Sedge

[1] Spiked trisetum

[2] Hairy wildrye

\section{COMMUNITY TYPES}

SACMA4. Bearberry-Juniper $(\mathrm{n}=14)$

\section{SITE CHARACTERISTICS}

Moisture regime: subxeric, mesic

Nutrient regime: poor, medium

Topographic position: upper slope

Slope: (16-30)(46-70)

Aspect: southerly

\section{SOIL CHARACTERISTICS}

Organic thickness: $(0-5)$

Humus form: mor

Surface texture: SL,S,L

Effective texture: SL,LS

Depth to Mottles/Gley: none

Drainage: rapid, well

Parent material: M,GF

Soil subgroup:, E.DYB, O.HFP, BR.GL, O.EB 


\section{GENERAL DESCRIPTION}

This ecosite is located on recent fluvial and glacialfluvial landforms with gentle slopes. The soils are poorly developed gravels and are rapidly drained. Yellow mountain avens, bearberry, juniper and junegrass are typical of these early successional river flats. The poor soil conditions limits the forage productivity and amount of regrowth after grazing. This ecosite should be rated as non-use range.

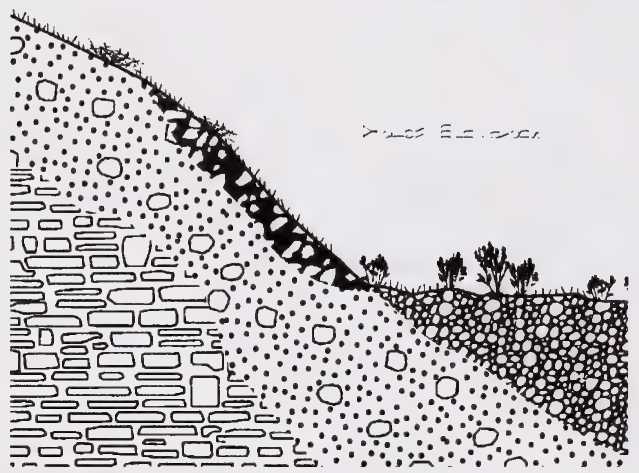

\section{SUCCESSIONAL RELATIONSHIPS}

Yellow mtn. avens generally dominates this community in the early successional stages. Succession in the absence of disturbance will be to balsam poplar, Engelmann spruce and subalpine fir.

\section{INDICATOR SPECIES}

yellow mtn. avens

willow

silverberry

juniper

showy locoweed

bearberry

alpine fireweed

sedge

\section{SITE CHARACTERISTICS}

Moisture regime: subxeric, submesic

Nutrient regime: poor, medium

Topographic position: floodplain

Slope: (0-5)

Aspect: variable

\section{SOIL CHARACTERISTICS}

\author{
Organic thickness: (0-2) \\ Humus form: mor \\ Surface texture: SL,SiL \\ Effective texture: SL, \\ Depth to Mottles/Gley: none \\ Drainage: rapid, well \\ Parent material: F,GF \\ Soil subgroup:, O.R
}

\section{ECOSITE PHASES}

bb1 yellow mtn. avens $(n=4)$ 


\section{CHARACTERISTIC SPECIES}

\section{Trees}

[2] Engelmann spruce

[1] Subalpine fir

[1] White spruce

\section{Shrubs}

[5] Willow

[1] Buffaloberry

[50] Yellow mtn. avens

[1] Shrubby cinquefoil

\section{Forbs}

[1] Alpine fireweed

[1] Showy locoweed

[1] Alpine goldenrod

\section{Graminoids}

[1] Sedge

[1] Spiked trisetum

\section{SITE CHARACTERISTICS}

Moisture regime: subxeric, submesic

Nutrient regime: poor, medium

Topographic position: floodplain

Slope: (0-5)

Aspect: variable

\section{SOIL CHARACTERISTICS}

Organic thickness: $(0-2)$

Humus form: mor

Surface texture: SL,SiL

Effective texture: SL,

Depth to Mottles/Gley: none

Drainage: rapid, well

Parent material: F, GF

Soil subgroup:, O.R

\section{COMMUNITY TYPES}




\section{c4 hairy wildrye grassland $(n=81)$}

\section{CHARACTERISTIC SPECIES}

Shrubs

[2] Juniper

[10] Shrubby cinquefoil

Forbs

[9] Bearberry

[2] Showy locoweed

[2] Strawberry

[1] Old man's whiskers

[1] White mtn. avens

[1] Yellow hedysarum

\section{Graminoids}

[5] Rough fescue

[15] Hairy wildrye

[5] Sedge

[ 5] Junegrass

\section{COMMUNITY TYPES}

SACMA3 Shrubby cinquefoil/Hairy wildrye $(n=5)$

SACMA5 Junegrass-Hairy wildrye-Brome $(n=19)$

SACMA6 Hairy wildrye/Bearberry-Juniper $(n=44)$

SACFA9 Rough fescue-Hairy wildrey-Sedge $(n=13)$

\section{SITE CHARACTERISTICS}

Moisture regime: subxeric, submesic,

Nutrient regime: medium

Topographic position: upper slope

Slope: $(16-30)(47-70)$

Aspect: southerly

\section{SOIL CHARACTERISTICS}

Organic thickness: $(0-2)(2-5)$

Humus form: no data

Surface texture: $\mathrm{SiL}$

Effective texture: SL,

Depth to Mottles/Gley: none

Drainage: rapid, well

Parent material: $\mathrm{M}$

Soil subgroup:, O.R, O.EB 


\section{CHARACTERISTIC SPECIES}

SACFA8 California oatgrass-Sedge $(n=5)$ SACMA1 Bog sedge-California oatgrass $(n=1)$ SACMA8 Alpine bluegrass $(n=1)$

Shrubs

[11] Willow

[13] Shrubby cinquefoil

Forbs

[5] Bearberry

[3] Veiny meadow rue

[8] Strawberry

[2] Yarrow

[2] Slender blue beardtongue

[1] Fireweed

\section{Graminoids}

[30] California oatgrass

[3] Hairy wildrye

[8] Sedge

[9] Bog sedge

[ 15] Alpine bluegrass

\section{SITE CHARACTERISTICS}

Moisture regime: mesic, subhygric, submesic,

Nutrient regime: medium, rich, poor

Topographic position: level, midslope

Slope: $(0-5)$

Aspect: variable

\section{SOIL CHARACTERISTICS}

Organic thickness: $(0-2)(2-5)$

Humus form: no data

Surface texture: SiL, L

Effective texture: SL, SiL, L

Depth to Mottles/Gley: none

Drainage: mod. well, well

Parent material: $M$

Soil subgroup:, O.R, O.EB, BR.GL 


\section{CHARACTERISTIC SPECIES}

\section{Shrubs}

[30] Willow

[7] Bog birch

\section{Forbs}

[1] Graceful cinquefoil

[1] Veiny meadow rue

[9] Strawberry

[2] Yarrow

[2] Globeflower

[1] Wandering daisy

\section{Graminoids}

[24] California oatgrass

[4] Mountain timothy

[10] Sedge

[1] Slender wheatgrass

[1] Spiked trisetum

\section{SITE CHARACTERISTICS}

Moisture regime: mesic, subhygric, submesic,

Nutrient regime: medium, rich, poor

Topographic position: level, midslope

Slope: $(0-5)$

Aspect: variable

\section{SOIL CHARACTERISTICS}

Organic thickness: $(0-2)(2-5)$

Humus form: no data

Surface texture: $\mathrm{SiL}, \mathrm{L}$

Effective texture: SL, SiL, L

Depth to Mottles/Gley: none

Drainage: mod. well, well

Parent material: $M$

Soil subgroup:, O.R, O.EB, BR.GL 


\section{d5 grouseberry $(n=4)$}

\section{CHARACTERISTIC SPECIES}

Trees

[1] Subalpine fir

\section{Shrubs}

[1] Willow

[14] Grouseberry

[ 5] Ground juniper

[1] Crowberry

\section{Forbs}

[12] Fireweed

[3] Small lv'd everlasting

[3] Strawberry

[2] Yarrow

\section{Graminoids}

[6] California oatgrass

[1] Sedge

[7] Spiked trisetum

\section{SITE CHARACTERISTICS}

Moisture regime: mesic, submesic,

Nutrient regime: medium

Topographic position: level, midslope

Slope: $(0-5)$

Aspect: variable

\section{SOIL CHARACTERISTICS}

Organic thickness: $(0-2)(2-5)$

Humus form: no data

Surface texture: SiL, L

Effective texture: SL, SiL, L

Depth to Mottles/Gley: none

Drainage: mod. well, well

Parent material: $M$

Soil subgroup:, O.R, O.EB, BR.GL 


\section{dd bog sedge meadow $(n=30)$}

\section{GENERAL DESCRIPTION}

This ecosite is located on moist well drained lowland sites adjacent to rivers and streams at higher elevations in the Central and Northern Foothills of the Subalpine. The presence of bog sedge appears to indicate the transition to the higher Alpine subregion. Indeed, Oglivie (1969) described bog sedge dominated community types on windswept ridges at higher elevations in the Alpine subregion. The forage production of this community is only moderate. Perhaps, the higher elevation and colder climate which favours the growth of bog sedge limits total productivity of this site.

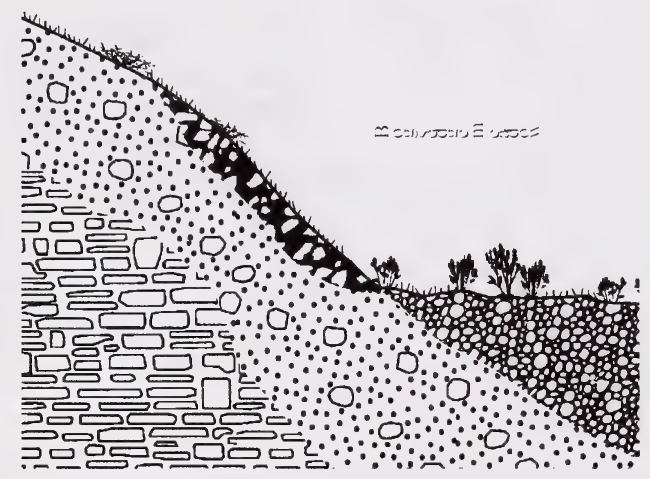

\section{SUCCESSIONAL RELATIONSHIPS}

Due to the nature of the site grasslands often remain the climax vegetation on these sites. In the absence of disturbance willow and bog birch often invade to form willow and bog birch dominated shrublands.

\section{subhygric/medium}

\section{SITE CHARACTERISTICS}

Moisture regime: mesic, subhygric

Nutrient regime: medium, rich

Topographic position: floodplain

Slope: (0-5)

Aspect: variable

\section{SOIL CHARACTERISTICS}

Organic thickness: $(0-15)$

Humus form: no data

Surface texture: L,SiL

Effective texture: SiL,

Depth to Mottles/Gley: none

Drainage: well, mod. well

Parent material: F, GF

Soil subgroup:, O.R, O.HR

\section{ECOSITE PHASES}

dd1 sedge-bog sedge $(\mathrm{n}=6)$

dd2 shrubland( $n=24)$

\section{INDICATOR SPECIES}

california oatgrass

bog sedge

rough fescue

tufted hairgrass

sedge

willow

bog birch

veiny meadow rue

sedge 


\section{dd1 sedge-bog sedge $(n=6)$}

\section{CHARACTERISTIC SPECIES}

\section{Shrubs}

[1] Shrubby cinquefoil

\section{Forbs}

[ 7] Alpine goldenrod

[3] Graceful cinquefoil

[1] Strawberry

[5] Yarrow

[6] Alpine bistort

\section{Graminoids}

[20] Bog sedge

[40] Sedge

[13] Tufted hairgrass

[7] Hairy wildrye

[3] Rocky mtn. fescue

\section{SITE CHARACTERISTICS}

Moisture regime: mesic, subhygric

Nutrient regime: medium

Topographic position: level, midslope

Slope: $(0-5)$

Aspect: variable

\section{SOIL CHARACTERISTICS}

Organic thickness: $(0-15)$

Humus form: no data

Surface texture: SiL, L

Effective texture: SL, SiL, L

Depth to Mottles/Gley: none

Drainage: mod. well, well

Parent material: $F$

Soil subgroup:, O.R, O.HR 


\section{CHARACTERISTIC SPECIES}

\section{Shrubs}

[7] Willow

[30] Bog birch

\section{Forbs}

[1] Alpine goldenrod

[2] Graceful cinquefoil

[ 3 ] Old man's whiskers

[1] Yarrow

[1] Alpine bistort

[2] False dandelion

[2] Tall larkspur

[1] Larkspur

\section{Graminoids}

[17] Bog sedge

[10] Sedge

[7] Rough fescue

[1] Hairy wildrye

[1] California oatgrass

\section{SITE CHARACTERISTICS}

Moisture regime: mesic, subhygric

Nutrient regime: medium

Topographic position: level, midslope

Slope: (0-5)

Aspect: variable

\section{SOIL CHARACTERISTICS}

Organic thickness: $(0-15)$

Humus form: no data

Surface texture: $\mathrm{SiL}, \mathrm{L}$

Effective texture: SL, SiL, L

Depth to Mottles/Gley: none

Drainage: mod. well, well

Parent material: F

Soil subgroup:, O.R, O.HR

\section{COMMUNITY TYPES}

SACFB8 Bog birch/Bog sedge-Sedge $(\mathrm{n}=5)$ SACFB9 Bog birch-Willow/Rough fescue $(n=4)$ SACFB10 Bog birch/Rough fescue-Bog sedge $(n=1)$ SACMB4 Willow-Bog birch/Bog sedge $(n=14)$ 


\section{CHARACTERISTIC SPECIES}

\section{Shrubs}

[2] Willow

[1] Bog birch

[1] Shrubby cinquefoil

\section{Forbs}

[3] Veiny meadow rue

[2] Graceful cinquefoil

[1] Old man's whiskers

[2] Yarrow

[1] Alpine bistort

[2] False dandelion

[2] Tall larkspur

\section{Graminoids}

[10] Tufted hairgrass

[10] Sedge

[2] Slender wheatgrass

[1] Hairy wildrye

[1] California oatgrass

\section{SITE CHARACTERISTICS}

Moisture regime: mesic, subhygric

Nutrient regime: rich, medium

Topographic position: level, midslope

Slope: $(0-5)$

Aspect: variable

\section{SOIL CHARACTERISTICS}

Organic thickness: $(0-15)$

Humus form: mor, moder

Surface texture: SiL, L

Effective texture: SiL, L, CL, C, SiCL, SCL, LS

Depth to Mottles/Gley: (0-25)

Drainage: mod. well, well, poor

Parent material: $\mathrm{F}$

Soil subgroup:, R.G, O.HG, O.HR, O.MB, CU.R

\section{COMMUNITY TYPES}




\section{e3 grazed grass meadow $(n=33)$}

\section{CHARACTERISTIC SPECIES}

\section{Shrubs}

[2] Willow

[1] Bog birch

[1] Shrubby cinquefoil

\section{Forbs}

[3] Veiny meadow rue

[2] Graceful cinquefoil

[1] Old man's whiskers

[2] Yarrow

[1] Alpine bistort

[2] False dandelion

[2] Tall larkspur

[3] Dandelion

\section{Graminoids}

[ 7] Tufted hairgrass

[10] Sedge

[2] Slender wheatgrass

[1] Hairy wildrye

[1] California oatgrass

[10] Creeping red fescue

[12] Kentucky bluegrass

[2] Rocky mtn. fescue

\section{SITE CHARACTERISTICS}

Moisture regime: mesic, subhygric

Nutrient regime: rich, medium

Topographic position: level, midslope

Slope: $(0-5)$

Aspect: variable

\section{SOIL CHARACTERISTICS}

Organic thickness: $(0-15)$

Humus form: mor, moder

Surface texture: SiL, L

Effective texture: SiL, L, CL, C, SiCL, SCL, LS

Depth to Mottles/Gley: (0-25)

Drainage: mod. well, well, poor

Parent material: $F$

Soil subgroup:, R.G, O.HG, O.HR, O.MB, CU.R
SACFA5 Sedge-Tufted hairgrass( $\mathrm{n}=7$ )

SACFA6 Sedge-Rocky Mtn. fescue-Alpine timothy $(\mathrm{n}=6)$

SACFA7 Sedge-Slender wheatgrass-Fringed brome/Forb $(n=18)$

SACFA15 Creeping red fescue-Sedge $(n=1)$

SACFA16 Kentucky bluegrass-Sedge/Dandelion(n=1) 


\section{CHARACTERISTIC SPECIES}

\section{Shrubs}

[30] Willow

[6] Bog birch

\section{Forbs}

[12] Variegated horsetail

[9] Common horsetail

[3] Showy everlasting

\section{Graminoids}

[6] Tufted hairgrass

[16] Sedge

\section{SITE CHARACTERISTICS}

Moisture regime: hygric, subhygric

Nutrient regime: rich, medium

Topographic position: level, midslope, toe

Slope: (0-5)

Aspect: variable

\section{SOIL CHARACTERISTICS}

Organic thickness: (6-15)

Humus form: mor

Surface texture: humic, SiL, L,SiCL

Effective texture: humic, SiL, L, SCL, SC

Depth to Mottles/Gley: $(0-25)(26-50)$

Drainage: mod. well, poor, imperfect

Parent material: F, M, FL

Soil subgroup:, R.HG, O.R, T.H

\section{COMMUNITY TYPES}




\section{h3 grass bog $(n=19)$}

\section{CHARACTERISTIC SPECIES}

\section{Shrubs}
[2] Willow
[2] Bog birch

\section{Forbs}

[1] Elephant's head

[2] Common horsetail

[1] Woolly everlasting

[1] Lanced leaved paintbrush

\section{Graminoids}

[8] Tufted bulrush

[15] Sedge

[3] Cottongrass

\section{SITE CHARACTERISTICS}

Moisture regime: subhydric, hygric

Nutrient regime: medium, poor

Topographic position: depression

Slope: (0-5)

Aspect: variable

\section{SOIL CHARACTERISTICS}

Organic thickness: $(>80)$

Humus form: peatymor

Surface texture: fibric

Effective texture: mesic

Depth to Mottles/Gley: (0-25)(26-50)

Drainage: poor, imperfect

Parent material: $\mathrm{O}$

Soil subgroup:, T.M, FI.OC
SACFA2 Tufted bulrush ( $\mathrm{n}=12)$

SACFA3 Sedge-Cottongrass $(n=7)$ 


\section{Results}

The analysis of the 848 plots distinguished 111 community types. These types were split into 4 categories:

\section{Subalpine}

Central and Northern Foothills
A. Native grasslands
17 community types
B. Native shrublands
11 community types

Central and Northern Rocky Mountains
A Native grasslands
9 community types
B. Native shrublands
8 community types

Southern Rocky Mountains
A. Native grasslands
20 community types
B. Native shrublands
9 community types
C. Grazed grasslands
14 community types
D. Deciduous
10 community types
E. Conifer
5 community types
F. Cutblock
1 community type

\section{Alpine}
A. Native grasslands and shrulands
7 community types

The dominant plant species, canopy cover, environmental conditions, forage production and carrying capacity (when available) are outlined for each community type. 


\section{SUBALPINE SUBREGION}

\section{SUBALPINE SHRUB AND GRASSLAND ECOLOGY}

The Subalpine subregion has highly variable ecological conditions. Much of the variation is the result of complex topography, with a strong ecotonal effect from the surrounding subregions. For instance the grasslands and shrublands of the foothills west of Sundre, Rocky Mtn. House, Hinton and Grande Cache are very similar to the tufted hairgrass, California oatgrass, sedge and rough fescue dominated grass and shrublands of the Upper Foothills subregion. This area is represented by the Central and Northern Foothills, an area dominated by morainal and residuum deposits, gentler slopes (16-45\%) and Brunisolic and Luvisolic soils. The Central and Northern Foothills are transitional from the lower Upper Foothills subregion to the higher and steeper Central and Northern Rocky Mountains of the Subalpine subregion. The Central and Northern Rocky Mountains are typical of the morainal and talus deposits on steeper slopes (10-100\%), with Brunisolic and Regosolic soils in Banff and Jasper National Parks. These areas are transitional from the lower Subalpine to the higher Alpine subregion. Many species such as bog sedge, heather spp., white mountain avens which are characteristic of alpine communities start to become predominant in these areas. Grasslands on steep, south-facing slopes are dominated by hairy wildrye, junegrass and shrubby cinquefoil.

In southern Alberta (west of Turner valley, south of Blairmore) the subalpine grasslands and shrublands are strongly influenced by the lower Montane subregion. Many of the grass species associated with the Montane (rough fescue, Parry oatgrass, Idaho fescue) dominate the south facing slopes of the Subalpine. These grasslands are very different from the hairy wildrye dominated community types found in the Central and Northern Rocky Mountains. The Southern Rocky Mountains are dominated by residuum, morainal and talus deposits on gentle to steep slopes (16-100\%). 


\section{SUBALPINE SUBREGION}

\section{CENTRAL AND NORTHERN FOOTHILLS}

\section{NATIVE GRASSLANDS AND SHRUBLANDS}

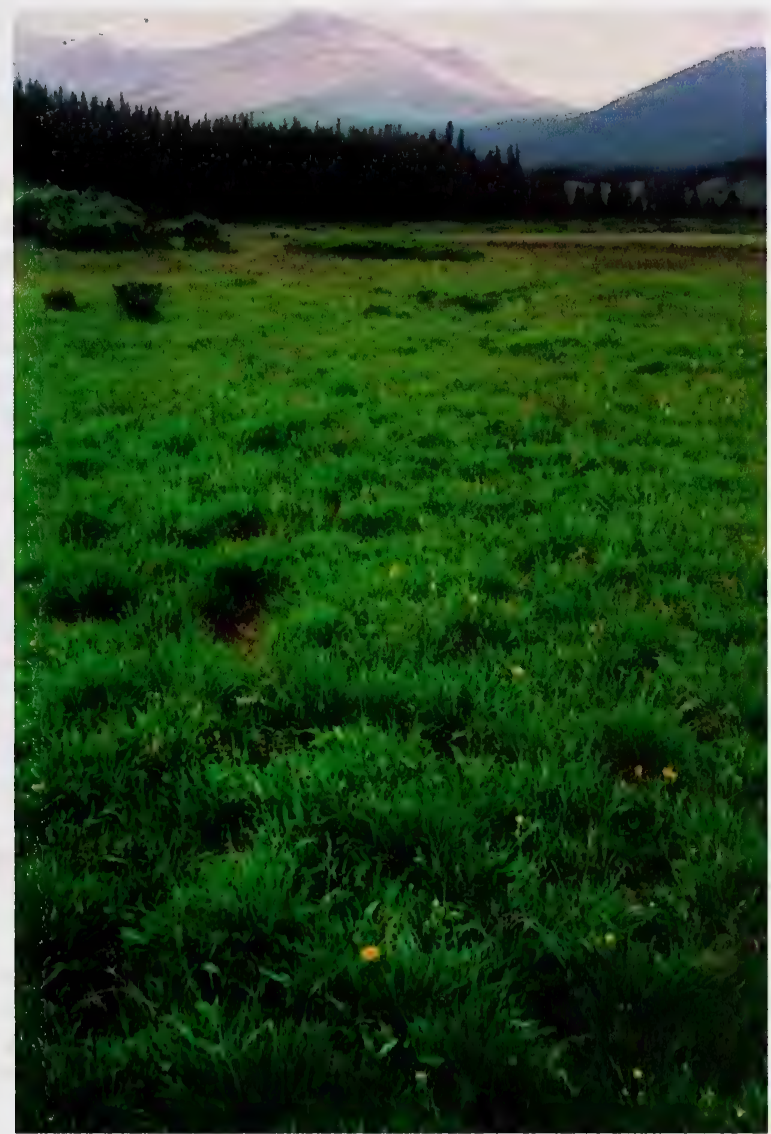

Figure 2. This figure is typical of the Tufted hairgrass-Sedge community with succession to a Willow-Bog birch dominated community type in the Central and Northern Foothills of the Subalpine subregion. 


\section{Native grass and shrubland ecology of the Foothills}

The native grass and shrubland community types in the Central and Northern Foothills of the Subalpine subregion (Table 2) are found in the valley bottoms adjacent to streams and rivers. The community types in this area are very similar to the grass and shrublands found in the Upper Foothills subregion and represent a transition from the lower Upper Foothills subregion to the Central and Northern Rocky Mountains of Banff and Jasper National Parks. The sequence of these community types along a moisture gradient from wet (Sedge meadows) to dry south facing slopes (Blunt sedge-Junegrass/Bearberry, Fringed sage/Junegrass-Sedge) is outlined in Figure 2. The change in species composition from the wet sedge meadows to tufted hairgrass, California oatgrass or rough fescue meadows may occur over a 3 foot elevational gradient. The presence of bog sedge (Kobresia myosuroides) in the White Mtn. avens-Bog sedge and SedgeBog sedge-Tufted hairgrass community types appears to indicate the transition from the lower Central and Northern Foothills to the higher Central and Northern Rocky Mountains. Ogilvie (1969) and Corns and Achuff (1982), described bog sedge dominated community types in the higher elevations of the subalpine and alpine of the Rocky Mountains of Banff and Jasper National Parks.

The maintenance of these grassland community types is extremely fire dependent. The lack of fire quickly allows bog birch and willow to expand shading the modal grassland community types. Prolonged shading causes the understory composition to shift from a tufted hairgrass-California oatgrass dominated understory to a slender wheatgrass-hairy wildrye dominated understory (Figure 3). Under a heavy shrub cover there is little forb or grass cover. Increased shrub cover also causes a decline in forage productivity and reduces the accessiblility for livestock.

Many of these subalpine grass and shrublands are very fragile because of exposure and cold climate. The forage productivity is generally only half of what is found in the lower Upper Foothills subregion and recovery from overgrazing will likely take some time because of the poor growing conditions. As a result grazing by domestic livestock should be done with caution. 
Table 2. Native grass and shrublands of the Central and Northern foothills ecodistricts of the Subalpine subregion

\begin{tabular}{|c|c|c|c|c|c|c|c|c|}
\hline \multirow{2}{*}{$\begin{array}{l}\text { Community } \\
\text { number }\end{array}$} & \multirow[t]{2}{*}{ Community type } & \multirow[b]{2}{*}{ Grass } & \multicolumn{3}{|c|}{ Productivity $(\mathrm{kg} / \mathrm{ha})$} & \multirow[b]{2}{*}{ Moisture } & \multirow[b]{2}{*}{ Drainage } & \multirow{2}{*}{$\begin{array}{l}\text { Carrying } \\
\text { capacity (Ha/AUM) }\end{array}$} \\
\hline & & & Forb & Shrub & Total & & & \\
\hline a1 & $\begin{array}{l}\text { Ecological site phases } \\
\text { shrubby grassland }\end{array}$ & 1235 & 264 & 13 & 1512 & Subxeric & Rapidly & 40.0 \\
\hline SACFA11. & Blunt sedge-Junegrass/Bearberry & 1235 & 264 & 13 & 1512 & Subxeric & Rapidly & 40.0 \\
\hline a2 & graminoid grassland & 807 & 393 & 178 & 1444 & Subxeric & Rapidly & 40.0 \\
\hline SACFA10. & Sedge-Hairy wildrye & 771 & 390 & 284 & 1444 & Subxeric & Rapidly & 40.0 \\
\hline SACFA12. & Fringed sage/Junegrass-Sedge & 1133 & 545 & 250 & 2126 & Subxeric & Rapidly & 40.0 \\
\hline SACFA14. & White Mtn. avens/Bog sedge & 517 & 245 & 0 & 762 & Subxeric & Rapidly & 40.0 \\
\hline c4 & hairy wildrye grassland & 1487 & 689 & 167 & 2343 & Submesic & Well & 0.7 \\
\hline SACFA9. & Rough fescue-Hairy wildrye-Sedge & 1487 & 689 & 167 & 2343 & Submesic & Well & 0.7 \\
\hline d4 & california oatgrass & 921 & 352 & $\mathbf{0}$ & 1273 & Submesic & Mod. Well & 1.2 \\
\hline SACFA8. & California oatgrass-Sedge & 921 & 352 & 0 & 1273 & Submesic & Mod. Well & 1.2 \\
\hline d5 & willow & 598 & 418 & 300 & 1316 & Subhygric & Mod.well & 1.3 \\
\hline SACFB6. & Willow-Bog birch/California oatgras & s598 & 418 & 300 & 1316 & Subhygric & Mod. well & 1.3 \\
\hline dd1 & sedge-bog sedge & 582 & 158 & $\mathbf{0}$ & 740 & Subhygric & Well & 1.2 \\
\hline SACFA13. & Sedge-Bog sedge-Tufted hairgrass & 582 & 158 & 0 & 740 & Subhygric & Well & 1.2 \\
\hline dd2 2 & shrubland & 1447 & 414 & 254 & 2115 & Mesic & Mod.well & 1.0 \\
\hline SACFB8. & Bog birch/Bog sedge-Sedge & 1333 & 390 & 202 & 1925 & Subhygric & Mod. well & 1.0 \\
\hline SACFB9. & Bog birch-Willow/Rough fescue & 1807 & 705 & 559 & 3071 & Mesic & Mod. well & 1.0 \\
\hline SACFB10. & Bog birch/Rough fescue-Bog sedge & 1201 & 147 & 0 & 1348 & Mesic & Well & 1.0 \\
\hline e1 & shrubby meadow & 774 & 401 & 101 & 1300 & Subhygric & Mod.well & 1.2 \\
\hline SACFB3. & Willow/Graceful sedge & 806 & 109 & 3 & 919 & Subhygric & Mod. well & 1.3 \\
\hline SACFB4. & Willow-Bog birch/Tufted hairgrass & 950 & 493 & 265 & 1803 & Subhygric & Mod. well & 1.3 \\
\hline SACFB7. & Willow-Bog birch/Hairy wildrye & 868 & 713 & 135 & 1716 & Subhygric & Well & 1.0 \\
\hline SACFB11. & Willow/Fringed brome-Sedge & 472 & 288 & 0 & 760 & Mesic & Imperfectly & 1.3 \\
\hline
\end{tabular}




\begin{tabular}{|c|c|c|c|c|c|c|c|c|}
\hline \multirow{2}{*}{$\begin{array}{l}\text { Community } \\
\text { number }\end{array}$} & \multirow[t]{2}{*}{ Community type } & \multirow[b]{2}{*}{ Grass } & \multicolumn{3}{|c|}{ Productivity $(\mathrm{kg} / \mathrm{ha})$} & \multirow[b]{2}{*}{ Moisture } & \multirow[b]{2}{*}{ Drainage } & \multirow{2}{*}{$\begin{array}{l}\text { Carrying } \\
\text { capacity (Ha/AUM) }\end{array}$} \\
\hline & & & Forb & Shrub & Total & & & \\
\hline e1a & grazed shrubby meadow & 1728 & 199 & 0 & 1927 & Subhygric & Mod.well & 1.4 \\
\hline SACFB5. & Willow-Bog birch/Clover-Dandelion & 1728 & 199 & 0 & 1927 & Subhygric & Mod. well & 1.4 \\
\hline e3 & grass meadow & 1002 & 1211 & 0 & 2212 & Subhygric & Mod. well & 0.7 \\
\hline SACFA4. & Tufted hairgrass-Sedge & 997 & 288 & 0 & 1284 & Subhygric & Mod. Well & 0.7 \\
\hline SACFA17. & Fireweed-Meadow rue/Sedge-Wildry & ye1006 & 2134 & 0 & 3140 & Subhygric & Mod. well & 0.7 \\
\hline e3a & grazed grass meadow & 814 & 173 & 3 & 851 & Mesic & Well . & 1.4 \\
\hline SACFA5. & Sedge-Tufted hairgrass & 785 & 146 & 0 & 931 & Subhygric & Mod. Well & 1.4 \\
\hline \multirow[t]{2}{*}{ SACFA6. } & Sedge-Rocky Mtn. fescue-Alpine & & & & & & & \\
\hline & Timothy & 661 & 326 & 7 & 994 & Mesic & Mod. Well & 1.4 \\
\hline \multirow[t]{2}{*}{ SACFA7. } & Sedge-Slender wheatgrass-Fringed & & & & & & & \\
\hline & Brome/Forb & 539 & 156 & 7 & 702 & Subhygric & Mod. Well & 1.3 \\
\hline SACFA15. & Creeping red fescue-Sedge & 1705 & 15 & 0 & 1720 & Mesic & Well & 0.6 \\
\hline SACFA16. & Kentucky bluegrass-Sedge/Dandelion & n 380 & 224 & 0 & 604 & Mesic & Well & 1.5 \\
\hline g2 & willow & & & & N/A & Subhygric & Poorly & 40.0 \\
\hline SACFB2. & Willow/Horsetail & - & - & - & N/A & Subhygric & Poorly & 40.0 \\
\hline h3 & grass bog & - & & - & N/A & Subhydric & Poorly & 1.0 \\
\hline SACFA2. & Tufted bulrush & - & - & - & N/A & Subhydric & Poorly & 1.0 \\
\hline SACFA3. & Sedge-Cottongrass & - & - & - & N/A & Subhydric & Poorly & 1.0 \\
\hline i2 & shrubby fen & 1234 & 129 & 1150 & 2514 & Hygric & Poorly & 40.0 \\
\hline SACFB1. & Willow-Bog birch/Water sedge & 1234 & 129 & 1150 & 2514 & Hygric & Poorly & 40.0 \\
\hline i3 & graminoid fen & 1215 & 774 & $\mathbf{0}$ & 1721 & Subhydric & Poorly & 0.5 \\
\hline SACFA1. & Water sedge-Beaked sedge & 1215 & 774 & 0 & 1721 & Subhydric & Poorly & 0.5 \\
\hline
\end{tabular}




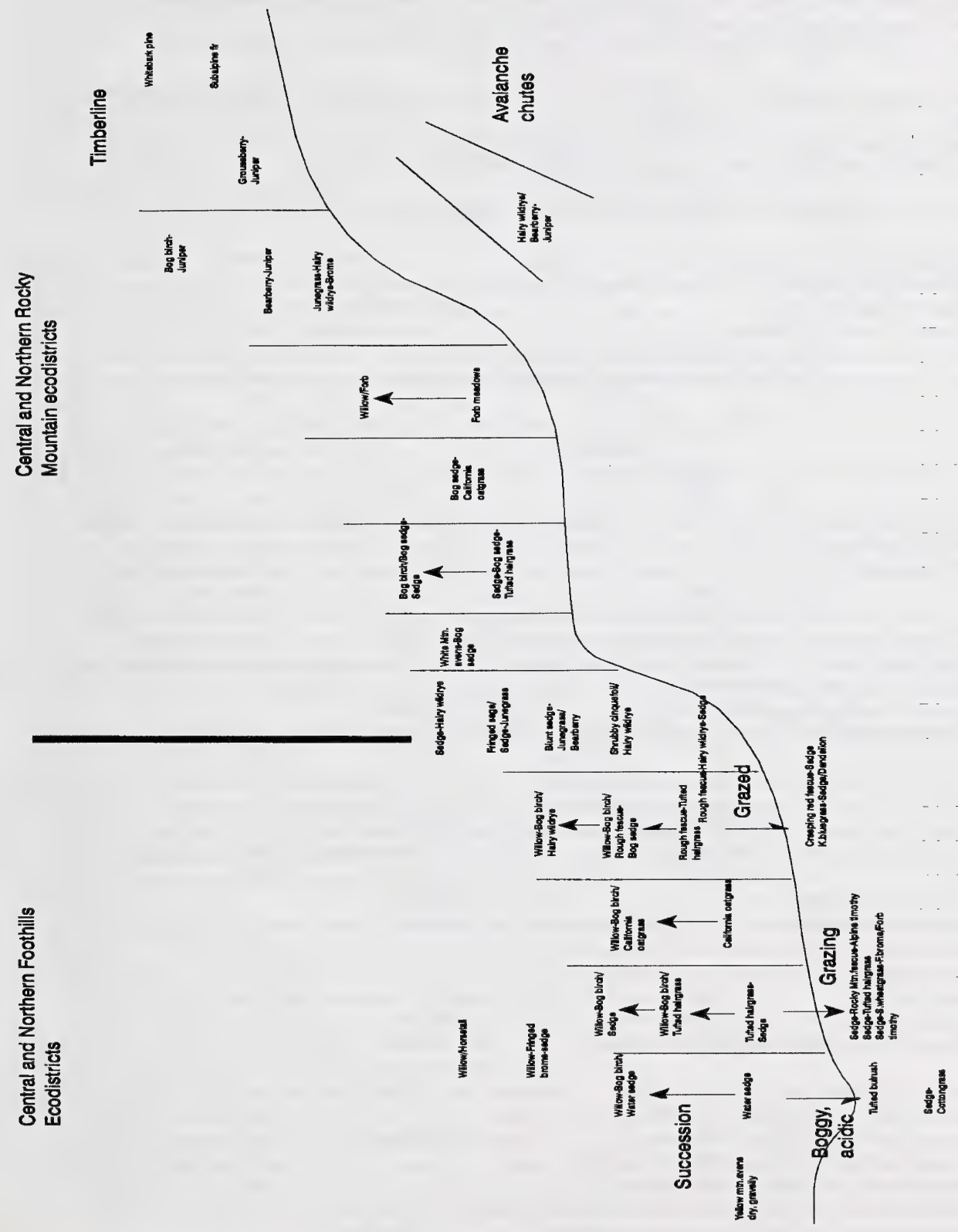

Figure 3. Grassland and shrubland community types in the landscape of the Central and Northern Rocky Mountain and Foothills areas of the Subalpine subregion 


\section{Native grass and shrublands in Central and Northern Mountain and Foothills areas}

1. Community above timberline (Alpine subregion)...........Alpine section of guide

Community not above timberline, meadows, shrublands or south facing slopes dominated by shrubs and grass.

2. Moist sites, community dominated by shrubs $>20 \%$ cover (willow, bog birch) or timberline communities with dwarf trees or grouseberry

see shrub key pg 34

Drier to moist sites shrub cover $<10 \%$ site dominated by grasses and forbs.

3

3. Community very wet free standing water, dominated by sedge, cottongrass or tufted bulrush

Community drier, dominated by tufted hairgrass, rough fescue, california oatgrass, hairy wildrye, juniper or bearberry.

4. Very wet nutrient rich sites dominated by water or beaked sedge. SACFA1

Very wet nutrient poor, acidic sites dominated by tufted bulrush and cottongrass.............

5. Site dominated by tufted bulrush.....

SACFA2

Site dominated by cottongrass and sedge...

SACFA3

6. Grasslands of meadows and lowland areas.

Grasslands of south facing slopes, or windswept ridges, hairy wildrye, bearberry, white mtn. avens dominated

7. Higher elevation sites near or at timberline, moist sites dominated by wandering daisy, globeflower, mountain marigold.

SACMA2

Lower elevation sites, valley bottoms adjacent to streams or rivers or if higher elevation dry sites dominated by bog sedge..

8

8. Disturbed or grazed community types dominated by Kentucky bluegrass, creeping red fescue, dandelion, alpine bluegrass, alpine timothy or fireweed. 9

Undisturbed community types dominated by rough fescue, California oatgrass, bog sedge, tufted hairgrass, and sedge species

14

9. Moderately grazed site native increasers dominant (slender wheatgrass, sedge, fringed brome, rocky mtn. fescue, alpine timothy), Alpine or Kentucky bluegrass increasing in cover.

10

Heavily grazed sites dominated by Kentucky bluegrass or abandoned airstrips dominated by creeping red fescue or native

forb species (fireweed, veiny meadow rue). 12

10. Site dominated by Alpine bluegrass.

SACMA8

Site dominated by rocky mtn. fescue, alpine timothy, sedge, slender wheatgrass, fringed brome (moister sites).

SACFA6

11. Site dominated by rocky $\mathrm{mtn}$. fescue, alpine timothy, sedge. SACFA7

Site dominated by slender wheatgrass, sedge, fringed brome.

11

12. Heavily grazed site dominated by Kentucky bluegrass and dandelion........SACFA16

Abandoned airstrips dominated by creeping red fescue, or invaded strips dominated by forbs (fireweed, veiny meadow).

SACFA15

13 Site dominated by creeping red fescue.

Moister disturbed site dominated by fireweed and veiny meadow rue...SACFA17

14. Moist sites dominated by sedge and tufted hairgrass.

Drier sites dominated by rough fescue, hairy wildrye, bog sedge, yellow dryas

or California oatgrass

SACFA4

5. Site dominated by tufted hairgrass, sedge co-dominant

SACFA5

16. Sites dominated by rough fescue and hairy wildrye.

SACFA9

Sites dominated by California oatgrass, bog sedge, or yellow dryas.

SACMA9

17. Gravelly river flats dominated by yellow dryas.

13

15

16

Meadow areas dominated by California oatgrass and/or bog sedge.

18. Site dominated by bog sedge and california oatgrass

Site dominated by california oatgrass and sedge, bog sedge not present.

SACFA8

19. Site dominated by bog sedge, california oatgrass, drier sites.

SACMA1

Site co-dominated by bog sedge, tufted hairgrass, and sedge moister sites... SACFA13

20. Lower elevation grasslands in the Foothills of the Subalpine.

Higher elevation grasslands in the mountains of the Subalpine

21 Northern wheatgrass dominated site. 
Fringed sage, sedge and junegrass dominated slope.

SACFA12

22. Avalanche slopes dominated by hairy wildrye, juniper, and bearberry....SACMA6

Drier sites or windswept ridges dominated hairy wildrye, juniper, bearberry, shrubby cinquefoil, white mtn. avens.

SACFA14

23. Windswept ridges dominated by white $\mathrm{mtn}$. avens

South facing slopes dominated by hairy wildrye

24. Shallow rocky soils with little grass cover, site dominated by bearberry.. SACMA4

Deeper soils, good grass cover dominated by hairy wildrye, junegrass.

SACMA3

25. Shrubby cinquefoil dominant in stand.

Grass cover extensive, dominated by hairy wildrye, junegrass, and brome....SACMA5

\section{Shrub dominated communities}

1. Timberline communities dominated by whitebark pine, subalpine fir, grouseberry, or willow communities with marsh marigold, wandering daisy or globeflower in understory 2

Riparian communities adjacent to streams or rivers

2. Trees present in community (whitebark pine, subalpine fir) or grouseberry dominated.... 3 Moist seepage areas at treeline dominated by globeflower, wandering daisy or marsh marigold in understory. .SACMB6

3. Trees (subalpine fir, whitebark pine) on site. Grouseberry dominated shrubland. SACMB7

4. Whitebark pine present ..SACMB3 Subalpine fir present SACMB8

5. Very wet sites with water sedge or horsetail dominated understories.

Drier sites with tufted hairgrass, california oatgrass, bog sedge, hairy wildrye, rough fescue Kentucky bluegrass, dandelion dominated understories

6. Water sedge dominated understory SACFB1, SACMB1 Horsetail dominated understory.

SACFB2

7. Grazed communities dominated by clover and dandelion in understory SACFB5

Ungrazed sites dominated by native forbs and grasses in understory.

8. Shrubland communities on seepage areas on south facing slopes with shallow soils, dominated by bog birch and juniper. SACMB5

Meadows and lowland shrublands dominated by rough fescue, bog sedge, california oatgrass, tufted hairgrass, hairy wildrye or sedge in the understory.

9. Rough fescue dominates the understory.

Tufted hairgrass, california oatgrass, bog sedge, sedge, hairy wildrye dominate.

10. Rough fescue and bog sedge dominate understory higher elevations

\section{SACFB10}

Rough fescue dominates, bog sedge not present lower elevations.

SACFB9

11. Moister sites with deep fluvial deposits dominated by tufted hairgrass, sedge, or fringed brome in understory.

Drier sites which are well drained at the surface dominated by hairy wildrye, sedge, bog sedge or california oatgrass in understory

12. Tufted hairgrass or sedge dominated understory

13

Fluvial areas with Fringed brome dominated understory, lower elevation.........SACFB11

13. Tufted hairgrass dominates understory

SACFB4

Graceful sedge and other sedge species dominate understory.

SACFB3, SASMB2

14. Modal sites with hairy wildrye and sedge dominating understory.

Sites dominated by california oatgrass or bog sedge in understory

15. Hairy wildrye dominates understory

Graceful sedge and other sedge species dominate understory

16. California oatgrass dominates understory..... Bog sedge dominates understory. 


\section{SACFA1. Water sedge-Beaked sedge meadows \\ (Carex aquatilis-Carex rostrata)}

$\mathbf{n}=11$ This community type is found in all ecodistricts of the subalpine. Wet conditions and periodic flooding result in the formation of water sedge-beaked sedge meadows. Bog birch and willow will invade into the drier edges of these meadows to form the Willow-bog birch/Water sedge community type.

These community types are quite productive producing nearly $2000 \mathrm{~kg} / \mathrm{ha}$ of forage, but the high water table in the spring and summer when these meadows are most palatable limits livestock use. A study in the Yukon found that crude protein on these meadows declined from a high of $10 \%$ in May to less than $5 \%$ in September (Bailey et al. 1992). As a result, these meadows would be rated as secondary or non-use range.

Plant Composition CANopy Cover(\%) Mean Range Const.

\section{SHRUBS}

SMOOTH WILLOW

(Salix glauca)

BOG BIRCH

(Betula glandulosa)

\section{FORBS}

ARROW LEAVED COLTSFOOT

(Petasites sagitatus) 7

GRASSES

WATER SEDGE

(Carex aquatilis)

BEAKED SEDGE

(Carex rostrata)

ROCKY-GROUND SEDGE

(Carex saxatilis)

TUFTED HAIRGRASS

(Deschampsia cespitosa)

$0-20 \quad 46$

$\begin{array}{lll}1 & 0-7 & 27\end{array}$

$3 \quad 0-20 \quad 46$

$7 \quad 0-14 \quad 18$

$23 \quad 0-62 \quad 64$

$11 \quad 0-42 \quad 55$

$9 \quad 0-70 \quad 18$

$0-5 \quad 64$
MOISTURE REGIME:

HYGRIC

NUTRIENT REGIME

PERMESOTROPHIC

ELEVATION:

$1750 \mathrm{M}$

SOIL DRAINAGE:

POORLY

ECOLOGICAL STATUS SCORE: 24

\section{Forage Production IN KG/HA}
GRASS 1215
FORBS 774
TOTAL $1721 *$ ESTIMATE

ECOLOGICALLY SUSTAINABLE STOCKING RATES GENERALLY NON-USE

$1.0(40.0-1.0) \mathrm{HA} / \mathrm{AUM}$

0.4(.01-0.4) AUM/AC

ENVIRONMENTAL VARIABLES 


\section{SACFA2. Tufted bulrush \\ (Scirpus cespitosus)}

$\mathbf{n = 1 2}$ This community type occurs on subhydric to hydric, lower subalpine sites (1490-1870 m) on nearly level slopes. Corns and Achuff (1982), described this community type on poorly drained soils in the valleys of Banff and Jasper National Park. The soils are dominated by Terric Mesisols and Orthic Gleysols. They felt this community type was successionally mature.

This community type and the Water sedge-Beaked sedge both occupy poorly drained sites with free standing water, but the dominance of tufted bulrush appears to indicate acidic boggy and peaty sites (Scoggan 1978).

\section{Plant Composition CANopy Cover(\%)} mean Range Const.

\section{SHRUBS}

SHRUBBY CINQUEFOIL

$\begin{array}{llll}\text { (Potentilla fruticosa) } & 6 & 0-35 & 75\end{array}$

BOG BIRCH

(Betula glandulosa) $\quad 3 \quad 0-10 \quad 50$

\section{FORBS}

ELEPHANT'S HEAD

(Pedicularis groenlandicum) $1 \quad 0-5 \quad 58$

WOOLY EVERLASTING

(Antennaria lanata) $\quad 1 \quad 0-5 \quad 42$

\section{GRASSES}

TUFTED BULRUSH

(Scirpus cespitosus)

WATER SEDGE

(Carex aquatilis)

RUSH-LIKE SEDGE

(Carex scirpoidea)
61

$18-85$

100

$2 \quad 0-10$

42

$1 \quad 0-10$

17

\section{ENVIRONMENTAL VARIABLES}

MOISTURE REGIME:

HYGRIC-SUBHYGRIC

NUTRIENT REGIME:

PERMESOTROPHIC

ELEVATION:

1678(1490-1870) M

SOIL DRAINAGE:

POORLY

ECOLOGICAL STATUS SCORE: 24

Forage Production Kg/Ha

Not AVAILABLE

ECOLOGICALLY SUSTAINABLE STOCKING RATES

GENERALLY NON-USE

1 (40.0-1.0)HA/AUM

0.4(.01-0.4) AUM/AC 


\section{SACFA3. Sedge-Cottongrass \\ (Carex spp.-Eriophorum spp.)}

$\mathbf{n}=\mathbf{7}$ Corns and Achuff (1982), described a cottongrass dominated community on hydric sites in the Upper subalpine on level to gentle slopes. They found the cottongrass communities to form on depressional areas where the snow melts late and seepage is recieved throughout the growing season. Cottongrass is also characteristic of muskegs and boggy marshes. It appears that this community is located on better drained areas adjacent to tufted bulrush dominated community type. The high acidity of the soil appears to favour the growth of cottongrass, rushlike sedge and rocky ground sedge over water sedge.

\section{PlaANT COMPOSITION CANOPY COVER(\%)} Mean Range Const.

\section{SHRUBS}

WILLOW SPP.

(Salix spp.)

BOG BIRCH

(Betula glandulosa)

4

$1-11$

100

$1 \quad 0-5$

43

FORBS

LANCED -LEAVED PAINT BRUSH

(Castilleja occidentalis) 2

WOOLLY EVERLASTING

(Antennaria lanata)

COMMON HORSETAIL

(Equisetum arvense)

\section{1}

3

\section{GRASSES}

RUSH-LIKE SEDGE

(Carex scirpoidea)

ROCKY-GROUND SEDGE

(Carex saxatilis) $\quad 12 \quad 0-80 \quad 29$

SHORT SEDGE

(Carex curta)

SHEATHED COTTONGRASS

(Eriophorum vaginatum) 1

TALL COTTONGRASS

(Eriophorum polystachion)5

$0-10 \quad 14$

$0-18 \quad 57$

\section{ENVIRONMENTAL VARIABLES}

MOISTURE REGIME:

HYDRIC-SUBHYGRIC

NUTRIENT REgIME:

EUTROPHIC

ELEVATION:

$1778(1260-2000) \mathrm{M}$

SOIL DRAINAGE:

POORLY

ECOLOGICAL STATUS SCORE: 24

Forage Prodcution KG/Ha

Not AVAILABLE

ECOLOGICALLY SUSTAINABLE STOCKING RATES GENERALLY NON-USE

1 (40.0-1.0)HA/AUM

0.4(.01-0.4) AUM/AC 


\section{SACFA4. Tufted hairgrass-Sedge \\ (Deschampsia cespitosa-Carex spp.)}

$\mathbf{n = 1 8}$ This community type is located on moist sites that are better drained and slightly drier than the pure sedge meadows. Willoughby(2005), found that tufted hairgrass is a common plant species on lowland sites in the valley bottoms of the Upper Foothills subregion. Willoughby (1992), found when this community type is protected from grazing for 25-30 years, willow and bog birch expand and tufted hairgrass and sedge decline. The decline in graminoid cover also results in a decline in available forage production. Continuous heavy grazing causes hairgrass to decline and the site will be invaded by Kentucky bluegrass and dandelion.

Bork (1994), found this community type to be the most productive type described in Willmore Wilderness park. Forage production averages over $2000 \mathrm{~kg} / \mathrm{ha}$ and can vary from $(800-3300 \mathrm{~kg} / \mathrm{ha})$. It is interesting to note that forage production on this community type declines from an average of $2200 \mathrm{~kg} / \mathrm{ha}$ in the Upper Foothills to $1555 \mathrm{~kg} / \mathrm{ha}$ in the Subalpine subregion. The shorter growing season and colder climate may account for this change in forage productivity. These community types when located next to backcountry campsites will be utilized by horses.

\section{Plant Composition Canopy Cover(\%)} Mean Range Const.

\section{SHRUBS}

BARCLAY'S WILLOW

(Salix barclayi)

$$
2 \quad 0-7
$$

\section{FORBS}

Slender Blue Beardstongue

\begin{tabular}{|c|c|c|}
\hline (Penstemon procerus) & 2 & $0-9$ \\
\hline VEINY MEADOW RuE & & \\
\hline (Thalictrum venulosum) & 5 & $0-14$ \\
\hline $\begin{array}{l}\text { YARROW } \\
\text { (Achillea millefolium) }\end{array}$ & 4 & $0-14$ \\
\hline SMOOTH LEAVED CINQUE & OIL & \\
\hline $\begin{array}{l}\text { (Potentilla diversifolia) } \\
\text { OLD MAN'S WHISKERS }\end{array}$ & 12 & $0-43$ \\
\hline (Geum triflorum) & 1 & $0-6$ \\
\hline $\begin{array}{l}\text { ALPINE GOLDENROD } \\
\text { (Solidago multiradiata) }\end{array}$ & 1 & $0-13$ \\
\hline
\end{tabular}

\section{Grasses}

GRACEFUL SEDGE

(Carex praegracilis) $\quad 38 \quad 0-85 \quad 94$

TUFTED HAIRGRASS

(Deschampsia cespitosa) $31 \quad 12-57 \quad 100$

SLENDER WHEATGRASS

(Agropyron trachycaulum) $2 \quad 0-12 \quad 33$

SHEEP FESCUE

(Festuca saximontana) $\quad 3 \quad 0-16 \quad 33$

HAIRY WILDRYE

(Elymus innovatus)

$3 \quad 0-20$

\section{ENVIRONMENTAL VARIABLES}

MOISTURE REGIME:

MESIC TO HYGRIC

NUTRIENT REGIME:

MESOTROPHIC TO PERMESOTROPHIC

ELEVATION:

1896(1630-2130) M

SOIL DRAINAGE:

MOD. WELL TO VERY POORLY

SLOPE:

$3(1-5) \%$

ASPECT:

VARIABLE

ECOLOGICAL STATUS SCORE: 24

Forage Production Kg/HA
Grass
FORBS 288(0-928)
TOTAL $1284(532-2118)$

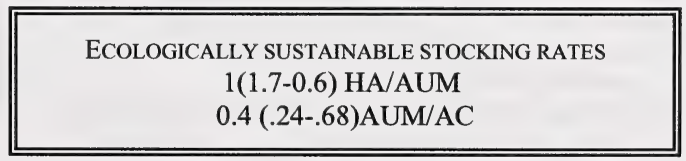




\section{SACFA5. Sedge-Tufted hairgrass \\ (Carex spp.-Deschampsia cespitosa)}

$\mathbf{n}=\mathbf{8}$ This community type was described in the Job Lake, Blackstone-Wapiabi Forest Land Use Zones. These areas are extensively utilized by equestrian backcountry users. This community type appears to develop from moderate to heavy grazing pressure on a Tufted hairgrass-Sedge community. Continued heavy grazing pressure appears to cause a further decline in tufted hairgrass to form the Sedge-Rocky Mtn. fescue-Alpine timothy and Sedge-Slender wheatgrass-Fringed brome/Forb community types. If the seed source becomes available these sites have the potential to be invaded by Kentucky bluegrass, timothy, clover and dandelion if the grazing pressure continues.

\section{Plant Composition Canopy Cover(\%)} mean Range Const.

\section{SHRUBS}

BOG BIRCH

(Betula glandulosa) $\quad 1 \quad 0-2 \quad 13$

\section{FORBS}

ALPINE BISTORT

$\begin{array}{llll}\begin{array}{l}\text { (Polygonum viviparum) } \\ \text { VEINY MEADOW RUE }\end{array} & 1 & 0-4 & 75 \\ \begin{array}{l}\text { (Thalictrum venulosum) } \\ \text { YARROW }\end{array} & 4 & 0-16 & 50 \\ \begin{array}{l}\text { (Achillea millefolium) } \\ \text { SMOOTH LEAVED CINQUEFOIL }\end{array} & 3 & 0-6 & 88 \\ \begin{array}{l}\text { (Potentilla diversifolia) } \\ \text { PURPLE AVENS }\end{array} & 9 & 0-18 & 75 \\ \begin{array}{l}\text { (Geum rivale) } \\ \text { GREEN SORREL }\end{array} & 7 & 0-42 & 63 \\ \begin{array}{l}\text { (Rumex acetosa) } \\ \text { (Rume }\end{array} & 2 & 0-8 & 75\end{array}$

GRASSES

GRACEFUL SEDGE

(Carex praegracilis) $\quad 58 \quad 19-98 \quad 100$

TUFTED HAIRGRASS

(Deschampsia cespitosa) $18 \quad 3-34 \quad 100$

KENTUCKY BLUEGRASS

(Poa pratensis) $\quad 4 \quad 0-15 \quad 75$

ALPINE FESCUE

(Festuca brachyphylla) $3 \quad 0-15 \quad 63$

CALIFORNIA OATGRASS

(Danthonia californica)

\section{ENVIRONMENTAL VARIABLES}

MOISTURE REGIME:

MESIC -SUBHYGRIC

NUTRIENT REGIME:

MESOTROPHIC TO PERMESOTROPHIC

ELEVATION:

1866(1832-1895) M

SOIL DRAINAGE:

WELL TO MOD. WELL

ECOLOGICAL STATUS SCORE: 16

Forage Production Kg/Ha

$\begin{array}{ll}\text { GRASS } & 785(341-1369) \\ \text { FORBS } & 146(0-443) \\ \text { TOTAL } & 931(412-1738)\end{array}$

ECOLOGICALLY SUSTAINABLE STOCKING RATES $1.4(2.2-1.0) \mathrm{HA} / \mathrm{AUM}$ $0.3(0.2-0.4) \mathrm{AUM} / \mathrm{AC}$ 


\section{SACFA6. Sedge-Rocky Mountain fescue-Alpine timothy (Carex praegracilis-Festuca saximontana-Phleum commutatum)}

$\mathbf{n}=\mathbf{6}$ This community type appears to arise from grazing of a modal Tufted hairgrass-Sedge community type. The six sites described in this community were all located next to outfitter campsites and had been heavily grazed by horses. The heavy grazing pressure causes tufted hairgrass to decline and allows non-native plants such as Kentucky bluegrass and dandelion to invade onto the site. The heavy grazing pressure also appears to change the moisture regime of the site. Many of the plant species on the site, Rocky mountain fescue, Alpine timothy, Alpine bluegrass, junegrass and hairy wildrye are better adapted to well drained, drier conditions. Perhaps, the removal of litter causes the water to drain away from the site more rapidly. Bork (1994), noticed this on similar sites in Willmore Wilderness park. This community type maybe grazed heavier than the previously described Sedge-Tufted hairgrass community type or it could be drier and the grazing pressure shifts the community to one dominated by more drought resistant species.

\section{Plant Composition Canopy Cover(\%)} Mean Range Const.

\section{SHRUB}

BOG BIRCH

$\begin{array}{llll}\text { (Betula glandulosa) } & 3 & 0-12 & 33\end{array}$

FORBS

SLENDER BLUE BEARDTONGUE

$\begin{array}{llll}\begin{array}{l}\text { (Penstemon procerus) } \\ \text { YARROW }\end{array} & 2 & 0-3 & 83 \\ \begin{array}{l}\text { (Achillea millefolium) } \\ \begin{array}{l}\text { GRACEFUL CINQUEFOIL } \\ \text { (Potentilla gracilis) }\end{array}\end{array} & 6 & 1-9 & 100 \\ \begin{array}{l}\text { CHICKWEED } \\ \text { (Cerastium arvense) }\end{array} & 1 & 0-13 & 83 \\ \begin{array}{l}\text { DANDELION } \\ \text { (Taraxacum offincinale) }\end{array} & 2 & 0-7 & 83 \\ \begin{array}{l}\text { NORTHERN VALERIAN } \\ \text { (Valeriana dioica) }\end{array} & 2 & 0-5 & 50\end{array}$

GrasseS

ROCKY MOUNTAIN FESCUE

(Festuca saximontana)

TUFTED HAIRGRASS

(Deschampsia cespitosa) $4 \quad 0-20 \quad 50$

KENTUCKY BLUEGRASS

(Poa pratensis)

$5 \quad 0-14 \quad 67$

GRACEFUL SEDGE

(Carex praegracilis) $\quad 9 \quad 0-42 \quad 50$

ALPINE TIMOTHY

(Phleum commutatum) $\quad 6 \quad 0-15 \quad 50$

\section{ENVIRONMENTAL VARIABLES}

MOISTURE REGIME:

SUBMESIC-SUBHYGRIC

NUTRIENT REGIME:

SUBMESOTROPHIC TO MESOTROPHIC

ELEVATION:

$1886(1634-2130) \mathrm{M}$

SOIL DRAINAGE:

WELL TO IMPERFECTLY

SLOPE: $6(2-10) \%$

ASPECT: VARIABLE

ECOLOGICAL STATUS SCORE: 8

Forage Production Kg/HA

$$
\begin{array}{ll}
\text { GrASS } & 661(294-1121) \\
\text { FORB } & 326(0-524) \\
\text { SHRUB } & 7(0-14) \\
\text { TOTAL } & 994(729-1341)
\end{array}
$$

ECOLOGICALLY SUSTAINABLE STOCKING RATES $1.4(2.2-1.0) \mathrm{HA} / \mathrm{AUM}$

$0.3(0.2-0.4) \mathrm{AUM} / \mathrm{AC}$ 


\section{SACFA7. Sedge-Slender wheatgrass-Fringed brome/Forbs \\ (Carex praegracilis-Agropyron trachycaulum-Bromus ciliatus/Forbs)}

$\mathbf{n = 1 8}$ This community type appears to arise from grazing of a modal Tufted hairgrass-Sedge community type. All the sites described in this community were found adjacent to outfitter campsites in the Job Lake, BlackstoneWapiabi forest land use zones. The heavy grazing pressure causes tufted hairgrass to decline and allows sedges, slender whatgrass and fringed brome to increase. This community type maybe slightly moister than the previously described Sedge-Rocky mountain fescue-Alpine timothy community. As a result there is succession to more mesic loving plants rather than the drought tolerant plants described in the previous community type.

\section{Plant Composition Canopy Cover(\%) Mean Range Const.}

\section{SHRUBS}

WILLOW SPP.

(Salix spp.)

$1 \quad 0-10$

33

FORBS

ALPINE BistorT

$\begin{array}{llll}\text { (Polygonum viviparum) } & 7 & 0-59 & 67\end{array}$

YARROW

(Achillea millefolium) 4

SMOOTH LEAVED CINQUEFOIL

(Potentilla diversifolia) 11

ALPINE GOLDENROD

(Solidago multiradiata) 4

STRAWBERRY

$\begin{array}{llll}\text { (Fragaria virginiana) } & 6 & 0-29 & 61\end{array}$

FALSE-DANDELION

(Agoseris glauca)

\section{GRASSES}

SLENDER WHEATGRASS

(Agropyron trachycaulum)

TUFTED HAIRGRASS

(Deschampsia cespitosa) 4

KENTUCKY BLUEGRASS

(Poa pratensis)

GRACEFUL SEDGE

(Carex praegracilis)

FRINGED BROME

(Bromus ciliatus)

HAIRY WILDRYE

(Elymus innovatus)

$3 \quad 0-22 \quad 72$

$0-21 \quad 83$

0-37 $\quad 72$

$0-28 \quad 72$

72

$0-15 \quad 50$

$0-20 \quad 33$

$0-26 \quad 78$

2-94 100

$50 \quad 2-94 \quad 100$

$14 \quad 0-50 \quad 78$

$8 \quad 0-46 \quad 44$

\section{ENVIRONMENTAL VARIABLES}

MOISTURE REGIME:

MESIC-HYGRIC

NUTRIENT REGIME:

MESOTROPHIC-PERMESOTROPHIC

ELEVATION:

1926(1830-2076) M

SOIL DRAINAGE:

WELL TO MODERATELY WELL

ECOLOGICAL STATUS SCORE: 16 OR 8

\section{Forage Production KG/Ha}

ECOLOGICALLY SUSTAINABLE STOCKING RATES

$1.3(2.6-0.8) \mathrm{HA} / \mathrm{AUM}$ OR

$0.31(0.16-0.51)$ AUM/AC 


\section{SACFA8. California oatgrass-Sedge \\ (Danthonia californica-Carex spp.)}

$\mathbf{n}=\mathbf{5}$ This community is very similar to a community type described by Willoughby(2005) in the Upper Foothills subregion. Corns and Achuff (1982), described a Willow/California oatgrass dominated community type in Banff and Jasper National Park. It appears dry, gravelly or stony soils, with a fluctuating water table support this moderately productive grassland. Small pockets of this community type occur throughout the Subalpine subregion. In the Yukon these small meadows were found to form in depressions which appeared to act as pronounced frost pockets (Bailey et al. 1992). The cold air drainage and poor nutrient quality of the soil limits the forage productivity of these sites.

\section{PLANT COMPOSITION CANOPY COVER(\%)} Mean Range Const.

\section{SHRUBS}

WILLOW SPP.

(Salix spp.)

$3.8 \quad 0-13 \quad 60$

SHRUBBY CINQUEFOIL

(Potentilla fruticosa)

\section{ENVIRONMENTAL VARIABLES}

MOISTURE REGIME:

SUBMESIC

NUTRIENT REGIME:

MESOTROPHIC

ELEVATION:

$1830(1380-2100) \mathrm{M}$

SOIL DRAINAGE:

MODERATELY WELL TO WELL

ECOLOGICAL STATUS SCORE: 24

Forage Production Kg/Ha

GRASS 921

FORBS 352

TOTAL $1273 *$ EstimATE

SLENDER BLUE BEARDTONGUE

(Penstemon procerus)

$0-30 \quad 60$

\section{Grasses}

CALIFORNIA OATGRASS

$\begin{array}{llrl}\text { (Danthonia californica) } & 37 & 15-60 & 100\end{array}$

GRACEFUL SEDGE

(Carex praegracilis) $24 \quad 0-63 \quad 40$

SLENDER WHEATGRASS

(Agropyron trachycaulum) $3 \quad 0-15 \quad 20$

HAIRY WILDRYE

(Elymus innovatus) $\quad 11 \quad 0-29 \quad 60$

SPIKED TRISETUM

(Trisetum spicatum) $\quad 1 \quad 0-5 \quad 60$

BOG SEDGE

(Kobresia myosuroides)

4

$0-19 \quad 20$ 


\section{SACFA9. Rough fescue-Hairy wildrye-Sedge \\ (Festuca scabrella-Elymus innovatus-Carex spp.)}

$\mathbf{n}=13$ This community was described in the Panther Corners Forest Land Use Zone and in Willmore Wilderness Park on level to undulating ridges, terraces and lower slope positions with Orthic Eutric Brunisolic soils. It is very similar to the Rough fescue-Hairy wildrye community described by Willoughby(2005) in the Upper Foothills subregion and the Rough fescue-Wheatgrass-Hairy wildrye community described by Morgantini and Russell (1983) on Ribbon flats just north of the Panther Corners. This community type is moderately productive and one of the most important communities for wintering elk (Morgantini and Russell 1983). An examination of winter elk diets found that rough fescue made up 45 to $60 \%$ of their food intake during the months of December, January and March (Morgantini and Russell 1983). Care must be taken that this community type is not over-utilized by horses and that sufficient forage is left for overwintering elk.

\section{Plant Composition Canopy Cover(\%)} Mean Range Const.

\section{SHRUBS}

SHRUBBY CINQUEFOIL

(Potentilla fruticosa)

$\begin{array}{lll}8 & 0-31 \quad 92\end{array}$

\section{FORBS}

TALL LARKSPUR

(Delphinium glaucum) $1 \quad 0-7$

WILD STRAWBERRY

(Fragaria virginiana)

GRACEFUL CINQUEFOIL

(Potentilla gracilis) $\quad 4 \quad 0-11 \quad 62$

YARROW

(Achillea millefolium)

OLD MAN'S WHISKERS

(Geum triflorum)

AMERICAN VETCH

(Vicia americana)

\section{Grasses}

ROUGH FESCUE

(Festuca scabrella)

SEDGE

(Carex spp.)

SLENDER WHEATGRASS

(Agropyron trachycaulum) 3

HAIRY WILDRYE

(Elymus innovatus) $\quad 6 \quad 1-18 \quad 100$

JUNEGRASS

$\begin{array}{llll}\text { (Koeleria macrantha) } & 1 & 0-4 & 85\end{array}$

\section{ENVIRONMENTAL VARIABLES}

MOISTURE REGIME:

SUBXERIC TO MESIC

NUTRIENT REGIME:

MESOTROPHIC -PERMESOTROPHIC

ELEVATION:

$1786(1600-2150) \mathrm{M}$

SOIL DRAINAGE:

WELL TO RAPIDLY

SLOPE:

$$
32(10-60) \%
$$

ASPECT:

SOUTHERLY

ECOLOGICAL STATUS SCORE: 24

\section{Forage Production Kg/HA}

$\begin{array}{ll}\text { GRASS } & 1487(454-3056) \\ \text { FORBS } & 689(302-1792) \\ \text { SHRUB } & 167(0-968) \\ \text { TOTAL } & 2343(1284-4060)\end{array}$

ECOLOGICALLY SUSTAINABLE STOCKING RATES $0.7(0.9-0.4) \mathrm{HA} / \mathrm{AUM} \mathrm{OR}$ $0.6(0.0 .5-1.0) \mathrm{AUM} / \mathrm{AC}$ 


\section{SACFA10. Sedge-Hairy wildrye \\ (Carex spp.-Elymus innovatus)}

n=13 This community was described in the Panther Corners Forest Land Use Zone on steep west and south facing slopes at higher elevations. It occupies sites that are similar to the Fringed sage/Sedge-Junegrass community, but this community type is found at elevations averaging over 2000 meters. This community type is similar to the hairy wildrye dominated communities described by Corns and Achuff (1982) at higher elevations in the subalpine of the Central Mountains ecodistrict (SACMA,4,5,6). This community type was only lightly utilized by elk. In contrast the lower elevation Fringed sage/Sedge-Junegrass exhibited signs of heavy elk use. The higher elevation of this community may limit access to wildlife in this area. It is possible that if this community type was heavily grazed it may resemble the Fringed sage/Sedge-Junegrass community described at lower elevations.

\section{Plant Composition Canopy Cover(\%)} Mean Range Const.

\section{SHRUBS}

SHRUBBY CINQUEFOIL

(Potentilla fruticosa)

$4 \quad 0-14 \quad 77$

\section{FORBS}

TALL LARKSPUR

\section{(Delphinium glaucum)}

WILD STRAWBERRY

(Fragaria virginiana)

GRACEFUL CINQUEFOIL

(Potentilla gracilis)

YARROW

\section{(Achillea millefolium)}

OLD MAN'S WHISKERS

(Geum triflorum)

AMERICAN VETCH

(Vicia americana)

BEARBERRY

(Arctostaphylos uva-ursi)

\section{GraSSES}

ROUGH FESCUE

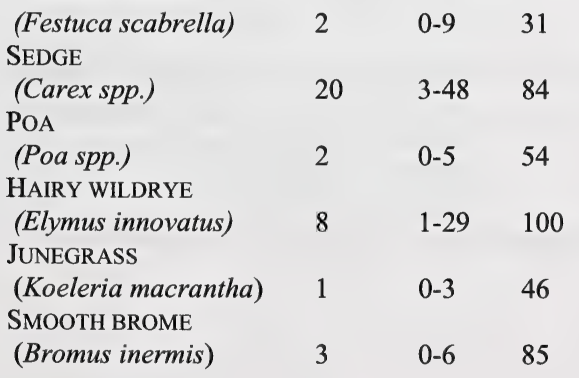

\section{ENVIRONMENTAL VARIABLES}

MOISTURE REGIME:

XERIC TO MESIC

NUTRIENT REGIME:

SUBMESOTROPHIC

ELEVATION:

2029( 1650-2300)M

SOIL DRAINAGE:

WELL TO RAPIDLY

ASPECT:

SLOPE:

SOUTHERLY AND WESTERLY

$36(0-50) \%$

ECOLOGICAL STATUS SCORE: 24

\section{Forage Production Kg/Ha}

$$
\begin{array}{ll}
\text { GRASS } & 771(460-1168) \\
\text { FORBS } & 390(160-1010) \\
\text { SHRUB } & 284(0-1712) \\
\text { TOTAL } & 1444(676-3150)
\end{array}
$$

\section{ECOLOGICALLY SUSTAINABLE STOCKING RATES GENERALLY NON-USE 40(40-1.0) HA/AUM .01(0.01-0.4) AUM/AC}




\section{SACFA11. Blunt sedge-Junegrass/Bearberry \\ (Carex obtusata-Koeleria macrantha/Arctostaphylos uva-ursi)}

$\mathbf{n = 3}$ This community type occurs on steep south facing slopes, with shallow soils, overlying sandstone bedrock. The majority of the vegetation are composed of drought tolerant species bearberry and junegrass. The inaccessibility and fragile nature of the soils make this community type unsuitable for grazing. This community is very similar to the Junegrass/Sage community described by Willoughby(2005) in the Upper Foothills subregion and the Low northern Sedge/Bearberry community described by Lawrence et al. (2005) in the Lower Foothills subregion on the south facing slopes of the Athabasca River valley.

\section{Plant Composition Canopy Cover(\%)}

Mean Range Const.

\section{SHRUBS}

SHRUBBY CINQUEFOIL

(Potentilla fruticosa)

$$
3
$$

100

\section{FORBS}

\section{BEARBERRY}

\section{(Arctostaphylos uva-ursi) 11}

SHOWY LOCOWEED

(Oxytropis splendens) $\quad 10$

SWEET FLOWERED ANDROSACE

(Androsace chamaejasme) 7

ALPINE GOLDENROD

(Solidago multiradiata) 1

COMMON YARROW

(Achillea millefolium) 7

\section{GrasseS}

\section{JUNEGRASS}

$\begin{array}{lccc}\begin{array}{l}\text { (Koeleria macrantha) } \\ \text { SHEEP FESCUE }\end{array} & 10 & 1-23 & 100 \\ \begin{array}{l}\text { (Festuca saximontana) } \\ \begin{array}{l}\text { BLUNT SEDGE } \\ \text { (Carex obtusata) }\end{array}\end{array} & 7 & 0-12 & 67 \\ \begin{array}{l}\text { HAIRY WILDRYE } \\ \text { (Elymus innovatus) }\end{array} & 3 & 0-6 & 67 \\ \begin{array}{l}\text { SLENDER WHEATGRASS } \\ \text { (Agropyron trachycaulum) } 3\end{array} & 1-5 & 100\end{array}$

\section{ENVIRONMENTAL VARIABLES}

MOISTURE REGIME:

XERIC TO SUBXERIC

NUTRIENT REGIME:

MESOTROPHIC

ELEVATION:

1990(1950-2070)M

SOIL DRAINAGE: RAPIDLY

SLOPE: $40(30-60) \%$

ASPECT: SOUTHERLY

ECOLOGICAL STATUS SCORE: 24

Forage Production KG/HA

GRASS 1235(1196-1274)

FORB 264(148-380)

SHRUB 13(0-26)

TOTAL 1512(1370-1654)

ECOLOGICALLY SUSTAINABLE STOCKING RATES GENERALLY NON-USE 40(40-1.0) HA/AUM $.01(0.01-0.4) \mathrm{AUM} / \mathrm{AC}$ 


\section{SACFA12. Fringed sage/White scaled sedge-Junegrass \\ (Artemisia frigida/Carex xerantica-Koeleria macrantha)}

$\mathbf{n}=\mathbf{5} \quad$ This community type occurs on steep south facing slopes, with shallow soils. It is very similar to the previously described Sedge-Junegrass/Bearberry community type, but lacks the cover of bearberry. The lack of bearberry cover in this community type may indicate that the soils of this type are better developed and slightly moister. The inaccessibility and fragile nature of the soils make this community type unsuitable for domestic livestock grazing. This community type is important winter habitat for migrating elk. The steepness of the slope and the southerly aspect limit snow accumulation and allows access to the forage supply. This community is very similar to the Junegrass/Sage community described by Willoughby(2005) in the Upper Foothills subregion.

\section{Plant Composition Canopy Cover(\%) MEAN RANGe CONST.}

\section{SHRUBS}

SHRUBBY CINQUEFOIL

$\begin{array}{llll}\begin{array}{l}\text { (Potentilla fruticosa) } \\ \text { PRICKLY ROSE }\end{array} & 2 & 0-4 & 80 \\ \begin{array}{l}\text { (Rosa acicularis) } \\ \text { Ros }\end{array} & 3 & 0-8 & 100\end{array}$

\section{FORBS}

BEARBERRY

(Arctostaphylos uva-ursi) 1

EARLY YELLOW LOCOWEED

(Oxytropis sericea) 3

FRINGED SAGE

(Artemisia frigida)

AMERICAN VETCH

(Vicia americana)

NORTHERN BEDSTRAW

(Galium boreale)

3

5

GrasseS

JUNEGRASS

(Koeleria macrantha)

WESTERN WHEATGRASS

(Agropyron smithii)

WHITE SCALED SEDGE

(Carex xerantica)

ROUGH FESCUE

(Festuca scabrella)

SLENDER WHEATGRASS

(Agropyron trachycaulum) 3

\section{ENVIRONMENTAL VARIABLES}

MOISTURE REGIME:

XERIC TO SUBXERIC

NUTRIENT REGIME:

SUBMESOTROPHIC

SLOPE: $53(45-60) \%$

ASPECT: SOUTHERLY

ELEVATION:

$1790(1650-1900) \mathrm{M}$

SOIL DRAINAGE: RAPIDLY

ECOLOGICAL STATUS SCORE: 24

\section{Forage Production KG/Ha}

Grass 1133(650-2206)

FORB 545(202-890)

SHRUB 250(0-556)

TOTAL 1928(936-3096)

ECOLOGICALLY SUSTAINABLE STOCKING RATES GENERALLY NON-USE 40(40-1.0) HA/AUM $.01(0.01-0.4) \mathrm{AUM} / \mathrm{AC}$ 


\section{SACFA13. Sedge-Bog sedge-Tufted hairgrass \\ (Carex praegracilis-Kobresia myosuroides-Deschampsia cespitosa)}

$\mathbf{n}=\mathbf{6}$ This community type is found on moist lowland sites at higher elevations in the Central and Northern Foothills. The presence of bog sedge appears to indicate the transition to the higher Alpine subregion . Indeed, Ogilvie (1969) described bog sedge dominated community types at higher elevations in the Alpine subregion.

The presence of bog sedge may also represent the transition between the foothills ecodistricts to the rocky mountain ecodistricts. Corns and Achuff (1982), described bog sedge dominated community types in the Subalpine subregion of Banff and Jasper National Parks.

The forage production on this community type is only moderate. Perhaps, the higher elevation and colder climate which favours the growth of bog sedge limits the total productivity of the site. Camping and grazing of these communities by horses should be restricted.

\section{Plant CoMposition Canopy Cover(\%)}

\section{Mean RANGe CONST.}

\section{SHRUBS}

SHRUBBY CINQUEFOIL.

(Potentilla fruticosa)

$$
1 \quad 0-4
$$

\section{FORBS}

ALPINE GOLDENROD

\begin{tabular}{|c|c|c|}
\hline (Solidago multiradiata) & 7 & $1-15$ \\
\hline STRAWBERRY & & \\
\hline (Fragaria virginiana) & 1 & $0-4$ \\
\hline $\begin{array}{l}\text { GRACEFUL CINQUEFOIL } \\
\text { (Potentilla gracilis) }\end{array}$ & 3 & $0-10$ \\
\hline $\begin{array}{l}\text { YARROW } \\
\text { (Achillea millefolium) }\end{array}$ & 5 & $1-15$ \\
\hline $\begin{array}{l}\text { ALPINE BISTORT } \\
\text { (Polygonum viviparum) }\end{array}$ & 6 & $1-13$ \\
\hline $\begin{array}{l}\text { SMOOTH LEAVED CINQUE } \\
\text { (Potentilla diversifolia) }\end{array}$ & $\begin{array}{r}\text { OIL } \\
12\end{array}$ & $0-31$ \\
\hline
\end{tabular}

Grasses

GRACEFUL SEDGE

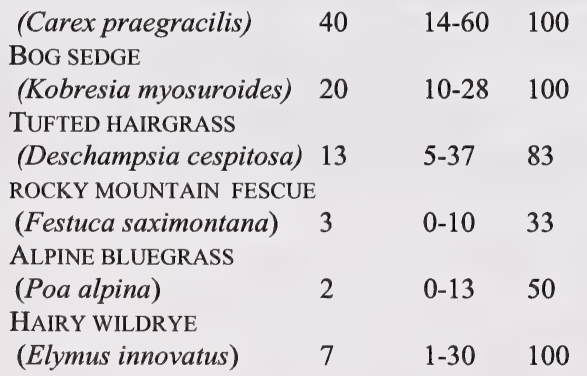

\section{ENVIRONMENTAL VARIABLES}

MOISTURE REGIME:

MESIC-SUBHYGRIC

NUTRIENT REGIME: MESOTROPHIC

ELEVATION:

$$
\text { 1900(1832-2438)M }
$$

SOIL DRAINAGE: IMPERFECTLY

SLOPE:

$$
1 \%
$$

ASPECT:

NORTHEAST

ECOLOGICAL STATUS SCORE: 24

\section{Forage Production Kg/Ha}

$$
\begin{array}{ll}
\text { GRASS } & 582(310-1002) \\
\text { FORB } & 158(58-272) \\
\text { TOTAL } & 740(582-1060)
\end{array}
$$

ECOLOGICALLY SUSTAINABLE STOCKING RATES GENERALLY NON-USE $1.2(1.6-0.9) \mathrm{HA} / \mathrm{AUM}$ $0.34(0.25-0.45)$ AUM/AC 


\section{SACFA14. White mountain avens/Bog sedge \\ (Dryas integrifolia/Kobresia myosuroides)}

$\mathbf{n}=\mathbf{3}$ This community type occupies shallow, stoney, wind exposed sites. It represents the transitional community between the bog sedge and white mountain avens community types described by Ogilvie (1969) and Corns and Achuff (1982) on windswept ridges in the Alpine and Subalpine subregions of the Rocky Mountains. The microsite conditions are very similar to higher elevation sites in the Rocky Mountains allowing this community to form in the lower Central Foothills.

The poor soil conditions limits the forage productivity and amount of regrowth after grazing. Often this community type is important winter range for bighorn sheep, because this community type remains snow free for much of the winter.

\section{Plant Composition Canopy Cover(\%)} mean Range Const.

FORBS

WHITE MOUNTAIN AVENS

$\begin{array}{llll}\text { (Dryas integrifolia) } & 46 & 1-41 & 67\end{array}$

ALPINE BISTORT

$\begin{array}{llll}\text { (Polygonum viviparum) } & 6 & 3-9 & 100\end{array}$

ALPINE HEDYSARUM

(Hedysarum alpinum) $\quad 2 \quad 0-4 \quad 100$

ALPINE MILKVETCH

(Astragalus alpinus)

$1 \quad 0-3 \quad 33$

GraSSES

BOG SEDGE

(Kobresia myosuroides) $11 \quad 1-32 \quad 100$

GRACEFUL SEDGE

(Carex praegracilis) $6 \quad 0-17 \quad 33$

HAIRY WILDRYE

$\begin{array}{llll}\text { (Elymus innovatus) } & 5 & 0-9 & 67\end{array}$

\section{LICHENS}

REINDEER LICHEN

(Cladina spp.)

$17 \quad 0-40$

\section{ENVIRONMENTAL VARIABLES}

MOISTURE REGIME:

XERIC-SUBXERIC

NUTRIENT REGIME:

SUBMESOTROPHIC

ELEVATION:

1912(1878-1981)M

SOIL DRAINAGE: RAPIDLY

SLOPE: $30 \%$

ASPECT: SOUTHERLY

ECOLOGICAL STATUS SCORE: 24

\section{Forage Production Kg/HA}
GRASS 517(89-945)
FORB 245(200-290)
TOTAL 762(289-1235)

ECOLOGICALLY SUSTAINABLE STOCKING RATES GENERALLY NON-USE 40 (40.0-1.0) HA/AUM .01(.01-0.4) AUM/AC 


\section{SACFA15. Creeping red fescue-Sedge \\ (Festuca rubra-Carex spp.)}

$\mathbf{n}=1 \quad$ This community type was described in the Blackstone-Wapiabi forest land use zone. It represents an old wellsite road that has been seeded to creeping red fescue. The creeping red fescue was probably used as the reclamation seed to stabilize the road from erosion. Presently, it is the recommendation of the forest service to use native seed in reclamation of these areas in the backcountry. Many of these agronomic mixes are highly invasive on the surrounding vegetation and there is the potential to introduce noxious weeds.

\section{Plant Composition Canopy Cover(\%) Mean Range Const. \\ SHRUBS}

WILLOW

(Salix barclayi)

$1 \quad-\quad 100$

\section{FORBS}

PALMATE LEAVED COLTSFOOT

(Petasites palmatus) 1

FIREWEED

(Epilobium angustifolium) 1

\section{Grasses}

CREEPING RED FESCUE

(Festuca rubra)

GRACEFUL SEDGE

(Carex praegracilis)

63

TUFTED HAIRGRASS

(Deschampsia cespitosa) 2

TIMOTHY

(Phleum pratense)
100

100

100

100

100

100

100

\section{ENVIRONMENTAL VARIABLES}

MOISTURE REGIME:

MESIC

NUTRIENT REGIME:

MESOTROPHIC

ELEVATION:

$1832 \mathrm{M}$

SOIL DRAINAGE:

WELL

SLOPE:

LEVEL

ECOLOGICAL STATUS SCORE: MODIFIED OR TAME PASTURE

Forage Production Kg/HA

GRASS 1705

FORB 15

TOTAL 1720

ECOLOGICALLY SUSTAINABLE STOCKING RATES

$0.7(1.0-0.5) \mathrm{HA} / \mathrm{AUM}$ OR

0.7(0.4-0.8) AUM/AC 


\section{SACFA16. Kentucky bluegrass-Sedge/Dandelion (Poa pratensis-Carex spp./Taraxacum officinale)}

$\mathbf{n = 1}$ This community type was described in the Job Lake forest land use zone. It represents a Tufted hairgrassSedge meadow that has been heavily grazed for a prolonged period of time. As a result there has been a decline in tufted hairgrass and other native plant species and an invasion of Kentucky bluegrass and dandelion. This community type is uncommon in the backcountry areas because of the lack of seed source for Kentucky bluegrass and dandelion. However, once established it is very competitive and will likely remain on the site. Kentucky bluegrass is very productive, but it quickly loses it nutrient quality in the dormant season. This loss of nutrient quality will impact wildlife utilizing the area.

\section{Plant Composition Canopy Cover(\%) \\ Mean RANGe CONST.}

\section{SHRUBS}

WILLOW

(Salix barclayi)$$
1
$$

\section{FORBS}

ALPINE BISTORT

$\begin{array}{llll}\text { (Polygonum viviparum) } & 18 & - & 100\end{array}$

GRACEFUL CINQUEFOIL

$\begin{array}{llll}\text { (Potentilla gracilis) } & 8 & - & 100\end{array}$

SWEET FLOWERED ANDROSACE

(Androsace chamaejasme) 3

ALPINE MILKVETCH

(Astragalus alpinus) $\quad 3$

MOUSE EARED CHICKWEED

(Cerastium arvense) 2

GrasSES

KENTUCKY BLUEGRASS

(Poa pratensis)

$36 \quad-\quad 100$

GRACEFUL SEDGE

(Carex praegracilis)

32

SLENDER WHEATGRASS

(Agropyron trachycaulum) 5
100

\section{ENVIRONMENTAL VARIABLES}

MOISTURE REGIME:

MESIC

NUTRIENT REGIME:

ELEVATION:

PERMESOTROPHIC

$1832 \mathrm{M}$

SoIl DRAINAGE: Well

SLOPE: LEVEL

ECOLOGICAL STATUS SCORE: 0

Forage Production Kg/HA

100

100

GRASS $\quad 380$

FORB 224

TOTAL 604 


\section{SACFA17. Fireweed-Meadow rue/Sedge \\ (Epilobium angustifolium-Thalictrum venulosum/Carex spp.)}

$\mathbf{n = 1}$ This community type was described in the Panther Corners forest land use zone adjacent to an abandoned air strip. The site was a moist site with a higher nutrient regime making it highly productive. This community type had not been extensively utilized by horses or wildlife and appears to be undergoing succession to a shrub dominated community type. Some invasion of agronomic species (smooth brome, bluegrass spp.) has occurred off the old airstrip into this community type.

\section{Plant Composition Canopy Cover(\%)} Mean Range Const.

\section{SHRUBS}

WILLOW

(Salix spp.)

T $\quad-\quad 100$

\section{FORBS}

FIREWEED

(Epilobium angustifolium)37 - $\quad 100$

VEINY MEADOW RUE

(Thalictrum venulosum) $22 \quad-\quad 100$

YARROW

(Achillea millefolium) 13

AMERICAN VETCH

(Vicia americana)$$
5
$$

NORTHERN BEDSTRAW

(Galium boreale)$$
4
$$

\section{GrasseS}

BLUEGRASS

(Poa spp.)

SEDGE

(Carex spp.)

21

SLENDER WHEATGRASS

(Agropyron trachycaulum)

SMOOTH BROME

(Bromus inermis)

HAIRY WILDRYE

(Elymus innovatus)

(1)

100

100

100

100

100

100

100

100

100

\section{ENVIRONMENTAL VARIABLES}

Moisture Regime: SUbHYGRIC

NUTRIENT REGIME:

PERMESOTROPHIC

ELEVATION: $1650 \mathrm{M}$

SOIL DRAINAGE:

MODERATELY WELL

SLOPE: LEVEL

ECOLOGICAL STATUS SCORE: 24

Forage Productionkg/HA

$\begin{array}{ll}\text { GRASS } & 1006 \\ \text { FORB } & 2134 \\ \text { TOTAL } & 3140\end{array}$
ECOLOGICALLY SUSTAINABLE STOCKING RATES $0.7(1.2-0.5) \mathrm{HA} / \mathrm{AUM}$ OR $0.6(.33-0.8) \mathrm{AUM} / \mathrm{AC}$ 


\section{SACFB1. Willow-Bog birch/Water sedge \\ (Salix spp.-Betula glandulosa/Carex aquatilis)}

$\mathbf{n}=9$ This shrub community appears on areas with very poor drainage. It is found in association with the wetter water sedge meadows. These sites are fairly productive but difficult to graze due to the moist ground conditions and heavy shrub cover which reduces access and mobility within the area. Increased flooding and prolonged waterlogging may result in the disappearance of willow and a transition to a water sedge meadow.

This community is similar to the water sedge-beaked sedge community in that it is found throughout the foothills and into the mountains. It maybe found in the Upper Foothills, Subalpine and lower Alpine subregions.

\section{Plant Compositioncanopy Cover(\%)} Mean Range Const.

SHRUBS

WILLOW

(Salix spp)

BOG BIRCH

(Betula glandulosa)

$$
30
$$$$
1-67
$$

100

$18 \quad 1-44 \quad 100$

\section{FORBS}

ELEPHANT'S HEAD

(Pedicularis groenlandicum) $1 \quad 0-6 \quad 78$

SMOOTH ASTER

(Aster laevis)

$2 \quad 0-8 \quad 56$

ALPINE BISTORT

(Polygonum viviparum) 1

SMOOTH LEAVED CINQUEFOIL

(Potentilla diversifolia) 2

ENTIRE LEAVED GROUNDSEL

(Senecio lugens)

2

$0-6$

78

$0-15 \quad 33$

$0-13 \quad 22$

\section{GRASSES}

WATER SEDGE

(Carex aquatilis)

TUFTED HAIRGRASS

(Deschampsia cespitosa) 4

$0-26$

89

GRACEFUL SEDGE

(Carex praegracilis) $\quad 2 \quad 0-20 \quad 11$

BALTIC RUSH

(Juncus balticus)

$5 \quad 0-17 \quad 56$

\section{ENVIRONMENTAL VARIABLES}

MOISTURE REGIME :

HYGRIC

Nutrient REgIME:

PERMESOTROPHIC

ELEVATION:

1760(1600-1950) M

SOIL DRAINAGE:

MODERATELY WELL TO POORLY

SLOPE:

$$
6(2-5) \%
$$

ASPECT:

SOUTHEASTERLY

ECOLOGICAL STATUS SCORE: 24

\section{Forage Production Kg/HA}
GRASS
FORBS 129(0-354)
SHRUB 1150(0-2990)
TOTAL 2514(1870-3848)

ECOLOGICALLY SUSTAINABLE STOCKING RATE GENERALLY NON-USE 40 (40.0-1.0) HA/AUM .01(.01-0.4) AUM/AC 


\section{SACFB2. Willow/Horsetail \\ (Salix spp./Equisetum spp.)}

$\mathbf{n = 4}$ This community type occupies level to gently sloping, fluvial landforms at lower elevations in the subalpine. The sites are hygric and imperfectly to poorly drained. This community borders rivers and streams and is transitional to the spruce, subalpine fir, horsetail dominated forest.

\section{Plant Composition Canopy Cover(\%)} Mean Range Const.

SHRUBS

WILLOW SPP.

(Salix spp.)

$32 \quad 5-56 \quad 100$

BOG BIRCH

(Betula glandulosa)

$5 \quad 0-20 \quad 60$

FORBS

VARIEGATED HORSETAIL

(Equisetum variegatum)

COMMON HORSETAIL

(Equisetum arvense)

WOOLLY EVERLASTING

(Antennaria lanata)

10

$0-40 \quad 60$

$10 \quad 0-25 \quad 60$

$1 \quad 0-3 \quad 40$

GrasseS

SEDGE SPP.

(Carex spp.)

14

3-25 $\quad 100$

TUFTED HAIRGRASS

(Deschampsia cespitosa) 1
$0-3 \quad 60$

\section{ENVIRONMENTAL VARIABLES}

MOISTURE REGIME :

SUBHYGRIC

NUTRIENT REGIME:

PERMESOTROPHIC

ELEVATION:

1512(1260-1810) M

SOIL DRAINAGE:

POORLY

ECOLOGICAL STATUS SCORE: 24

Forage Production Kg/HA

NONE AVAILABLE

ECOLOGICALLY SUSTAINABLE STOCKING RATE GENERALLY NON-USE 40 (40.0-1.3) HA/AUM $.01(.01-.31) \mathrm{AUM} / \mathrm{AC}$ 


\section{SACFB3. Willow/Graceful sedge \\ (Salix spp./Carex praegracilis)}

$\mathbf{n}=\mathbf{6}$ This community type appears to represent a stage of succession onto tufted hairgrass meadows. When these communities are protected from disturbance (fire and grazing) willow and bog birch expand and tufted hairgrass declines. Willow growth also appears to favour the growth of tall forbs (veiny meadow rue, fireweed, aster) and slender wheatgrass. Fire has played a dominant role in controlling brush encroachment in the past and continued protection will allow continued shrub expansion, resulting in a decline in forage production.

\section{Plant Composition Canopy Cover(\%)} Mean Range Const.

\section{SHRUBS}

WILLOW SPP.

$\begin{array}{llll}\text { (Salix spp.) } & 35 & 18-55 & 100 \\ \text { BoG BIRCH } & & & \end{array}$

$\begin{array}{llll}\text { (Betula glandulosa) } & 1 & 0-3 & 50\end{array}$

\section{FORBS}

SMOOTH LEAVED CINQUEFOIL (Potentilla diversifolia) 8

STRAWBERRY

(Fragaria virginiana) 4

YARROW

(Achillea millefolium) 2

ALPINE BISTORT

(Polygonum viviparum) 2

SMALL LEAVED EVERLASTING

(Antennaria parviflora) 10

MEADOW RUE

(Thalictrum venulosum) 3

GrasseS

GRACEFULSEDGE

(Carex praegracilis)

TUFTED HAIRGRASS

(Deschampsia cespitosa) $9 \quad 0-41 \quad 67$

SLENDER WHEATGRASS

(Agropyron trachycaulum) 3

SPIKED TRISETUM

(Trisetum spicatum)
$0-44 \quad 50$

$0-17 \quad 50$

$0-8 \quad 83$

$0-10 \quad 50$

$0-56 \quad 33$

$0-15 \quad 17$

$0-13 \quad 33$

$0-16 \quad 33$
$35-73 \quad 100$

\section{ENVIRONMENTAL VARIABLES}

MOISTURE REGIME:

SUBHYGRIC

NUTRIENT REgIME:

PERMESOTROPHIC

ELEVATION:

$1876(1832-1985) \mathrm{M}$

SOIL DRAINAGE:

POORLY

ECOLOGICAL STATUS SCORE: 24

Forage Production Kg/Ha

GRASS 806(380-1369)

FORBS 109(52-224)

SHRUBS 3(0-10)

TOTAL 919(604-1421)

ECOLOGICALLY SUSTAINABLE STOCKING RATE

1.3(1.8-1.0) HA/AUM OR 0.31(.22-0.4) AUM/AC 


\section{SACFB4. Willow-Bog birch/Tufted hairgrass \\ (Salix glauca-Betula glandulosa/Deschampsia cespitosa)}

$\mathbf{n = 1 4}$ This community type is found in association with the Tufted hairgrass-Sedge c.t.. Willow encroachment into a tufted hairgrass meadow eventually results in this community type. Historically fire has played an important role in the maintenance of the grassland community type in this ecoregion. Continued fire suppression will eventually allow willow and bog birch to invade many of these grassy meadows.

Willoughby (1998) found that the encroachment of willow into the Tufted hairgrass-Sedge c.t. caused a decline in forage production from $2200 \mathrm{~kg} / \mathrm{ha}$ to $1800 \mathrm{~kg} / \mathrm{ha}$ in the Upper Foothills subregion. This community has a high cover of willow and very little forage for domestic livestock.

\section{PLANT COMPOSITION CANOPY COVER(\%)} Mean Range Const.

SHRUBS

SMOOTH WILLOW .

(Salix glauca)

BARRET'S WILLOW

(Salix barrattiana)

BOG BIRCH

(Betula glandulosa)

$$
26
$$$$
0-65
$$

86

$6 \quad 0-55 \quad 43$

$10 \quad 0-25 \quad 79$

\section{FORBS}

YARROW

(Achillea millefolium)

WILD STRAWBERRY

(Fragaria virginiana)

LINDLEY'S ASTER

(Aster ciliolatus)

MOUNTAIN HELIOTROPE

(Valeriana sitchensis)

TALL LARKSPUR

(Delphinium glaucum)

WANDERING DAISY

(Erigeron peregrinus)

$0-3 \quad 43$

$2 \quad 0-20 \quad 36$

$2 \quad 0-20 \quad 36$

$3 \quad 0-35 \quad 43$

$1 \quad 0-5 \quad 43$

$3 \quad 0-15 \quad 29$

\section{GRASSES}

TUFTED HAIRGRASS

(Deschampsia cespitosa) $19 \quad 2-35 \quad 100$

HAIRY WILDRYE

(Elymus innovatus) $2 \quad 0-5 \quad 36$

SEDGE

(Carex spp.)

$10 \quad 0-26 \quad 86$

\section{ENVIRONMENTAL VARIABLES}

\section{MOISTURE REGIME :}

MESIC TO SUBHYGRIC

NUTRIENT REGIME :

PERMESOTROPHIC

ELEVATION:

1828(1220-2210) M

SOIL DRAINAGE :

MOD. WELL

ECOLOGICAL STATUS SCORE: 24

Forage Production KG/Ha

GRASS 950

FORBS 493

SHRUBS 265

TOTAL $1803 *$ Estimate
ECOLOGICALLY SUSTAINABLE STOCKING RATE 1.3(1.8-1.0) HA/AUM OR $0.31(.22-0.4) \mathrm{AUM} / \mathrm{AC}$ 


\section{SACFB5. Willow-Bog birch/Clover-Dandelion \\ (Salix glauca-Betula glandulosa/Trifolium repens-Taraxacum officinale)}

$\mathbf{n = 1}$ This community type represents a Willow-Bog birch/Tufted hairgrass community that has been extensively grazed by horses. This community was described near a historic campsite in the South Ram river drainage. Longterm moderate grazing pressure or heavy grazing pressure over a couple of years causes tufted hairgrass to decline and allows sedge, slender wheatgrass, Kentucky bluegrass, clover and dandelion to increase (Willoughby 2005) These community types are highly productive for domestic livestock throughout the growing season, but the poor quality of Kentucky bluegrass, clover and dandelion, particularly, in the dormant season limits the use of these community types for wildlife.

Plant Composition Canopy Cover(\%) Mean Range Const.

\section{SHRUBS}

SMOOTH WILLOW .

(Salix glauca)

BOG BIRCH

(Betula glandulosa)

\author{
19
}

100

FORBS

YARROW
(Achillea millefolium)

WILD STRAWBERRY

(Fragaria virginiana)

DANDELION

(Taraxacum offincinale) 15

Clover

(Trifolium repens)

GRACEFUL CINQUEFOIL

(Potentilla gracilis)

11

4

15

16

18

18

\section{GRASSES}

TUFTED HAIRGRASS

(Deschampsia cespitosa) 10

SLENDER WHEATGRASS

(Agropyron trachycaulum) 6

SEDGE

(Carex spp.)

KENTUCKY BLUEGRASS

(Poa pratensis)

HAIRY WILDRYE

(Elymus innovatus)

\section{ENVIRONMENTAL VARIABLES}

MOISTURE REGIME:

MESIC

NUTRIENT REGIME :

MESOTROPHIC

ELEVATION:

$1966 \mathrm{M}$

SoIL DRAINAGE :

MOD. WELL

SLOPE:

$$
2 \%
$$

ASPECT:

\section{SOUTHEAST}

ECOLOGICAL STATUS SCORE: 8

Forage Production KG/HA

GRASS 1728

FORBS 199

TOTAL 1927

ECOLOGICALLY SUSTAINABLE STOCKING RATE $.28(.22-0.4) \mathrm{AUM} / \mathrm{AC}$ 


\section{SACFB6. Willow-Bog birch/California oatgrass \\ (Salix glauca-Betula glandulosa/Danthonia californica)}

$\mathbf{n}=19$ This community type likely develops from willow encroaching onto an oatgrass dominated meadow. The oatgrass meadows are found on dry, gravelly soils. These meadows may also form in frost pockets. The spread of willow is likely caused by lack of natural disturbance, such as fire. The cover of willow on this community type is fairly extensive. This will restrict access to domestic livestock. This community type would be rated as secondary range.

\section{Plant COMPOSITION CANOPY COVER(\%)} Mean Range Const.

\section{SHRUBS}

SMOOTH WILlOW

(Salix glauca)

BARRET'S WILLOW

(Salix barratiana)

BOG BIRCH

(Betula glandulosa)

FORBS

YARROW

(Achillea millefolium)

MOUNTAIN CINQUEFOIL

(Potentilla diversifolia)

WILD STRAWBERRY

(Fragaria virginiana)

WANDERING DAISY

(Erigeron peregrinus)

GLOBEFLOWER

(Trollius albiflorus)

NORTHERN VALERAIN

(Valeriana dioica)

GRASSES

CALIFORNIA OATGRASS

(Danthonia californica) $24 \quad 10-70 \quad 100$

SEDGE

(Carex spp.)

MOUNTAIN TIMOTHY

(Phleum commutatum)

HAIRY WILD RYE

(Elymus innovatus)

SPIKED TRISTEUM

(Trisetum spicatum)

$22 \quad 0-75 \quad 90$

$\begin{array}{lll}8 & 0-50 \quad 47\end{array}$

$\begin{array}{lll}7 & 0-50 \quad 58\end{array}$

$2 \quad 0-9 \quad 68$

$0-6 \quad 63$

0-33 90

$0-6 \quad 42$

$0-25 \quad 26$

$0-8 \quad 21$

$\begin{array}{lll}4 & 0-21 \quad 68\end{array}$

$4 \quad 0-35 \quad 68$

$1 \quad 0-15 \quad 32$

$3 \quad 0-20 \quad 68$

\section{ENVIRONMENTAL VARIABLES}

MOISTURE REgIME :

MESIC-SUBHYGRIC

NUTRIENT REGIME:

MESOTROPHIC

ELEVATION:

1888(1360-2340) M

SOIL DRAINAGE:

MODERATELY WELL TO WELL

ECOLOGICAL STATUS SCORE: 24

Forage Production KG/HA

$\begin{array}{ll}\text { GRASS } & 598 \\ \text { FORBS } & 418 \\ \text { SHRUBS } & 300 \\ \text { TOTAL } & 1316^{*} \text { ESTIMATE }\end{array}$

ECOLOGICALLY SUSTAINABLE STOCKING RATE 


\section{SACFB7. Willow-Bog birch/Hairy wildrye \\ (Salix glauca-Betula glandulosa/Elymus innovatus)}

$\mathbf{n = 2 0}$ This community is typical of the valley bottoms where the low temperatures prohibit the growth of trees. Corns and Achuff (1982) described a similar community in the Banff and Jasper National Parks. They found this community type occupied coarse stream deposits which had repeated flooding.

Bork (1994) felt this community type developed from the invasion of willow and bog birch onto grasslands in the absence of disturbance in Willmore Wilderness park. Willow cover has increased, shading the growth of grasses and allowing tall-growing forbs, such as fireweed, aster and veiny meadow rue to increase. He felt continued protection from disturbance will allow succession to shrub and eventually tree species, which will increase shading of the understory vegetation and eventually lower forage production.

\section{PlaAt Composition CANopy Cover(\%)} Mean Range Const.

TREES

WHITE SPRUCE

(Picea glauca)

T $\quad 0-3 \quad 5$

SHRUBS

WILLOW SPP.

(Salix glauca)

BOG BIRCH

(Betula glandulosa)

30

8-52 100

$24 \quad 2-58 \quad 90$

FORBS

NORTHERN VALERIAN

(Valeriana dioica)

YARROW

(Achillea millefolium)

FIREWEED

(Epilobium angustifolium) 3

STRAWBERRY

(Fragaria virginiana) $\quad 4 \quad 0-12 \quad 80$

TALL LARKSPUR

(Delphinium glaucum)

GRASSES

BOG SEDGE

(Kobriesia myosuroides) 5

HAIRY WILDRYE

(Elymus innovatus)

GRACEFUL SEDGE

(Carex praegracilis) 3

SLENDER WHEATGRASS

(Agropyron trachycaulum) 3

\section{ENVIRONMENTAL VARIABLES}

MOISTURE REGIME:

XeRIC TO SUBHYGRIC

NUTRIENT REGIME:

MESOTROPHIC

ELEVATION:

1926(1560-2250) M

SOIL DRAINAGE:

RAPIDLY TO MODERATELY WELL

SLOPE:

$3(1-10) \%$

ASPECT:

EASTERLY

ECOLOGICAL STATUS SCORE: 24

Forage Production KG/Ha

$\begin{array}{ll}\text { GRASS } & 868(756-1003) \\ \text { FORBS } & 713(85-2120) \\ \text { SHRUB } & 135(0-540) \\ \text { TOTAL } & 1716(1088-2898)\end{array}$

ECOLOGICALLY SUSTAINABLE STOCKING RATE $1.0(1.3-0.5) \mathrm{HA} / \mathrm{AUM} \mathrm{OR}$ $0.4(.31-0.8) \mathrm{AUM} / \mathrm{AC}$ 


\section{SACFB8. Bog birch/Bog sedge-Sedge \\ (Betula glandulosa/Kobresia myosuroides-Carex spp.)}

$\mathbf{n}=\mathbf{5}$ This community type was described on moist lowland sites at higher elevations in the Central and Northern foothills ecodistricts. It appears this community type originated from recent shrub encroachment onto sedge-bog sedge-tufted hairgrass community type. The presence of bog sedge may represent the transition between the foothills ecodistricts and the rocky mountain ecodistricts. Corns and Achuff(1982) described bog sedge dominated community types in the Central and Northern Rocky Mountains of the Subalpine subregion of Banff and Jasper National Parks. Camping and grazing of these communities by horses should be restricted.

\section{Plant Composition Canopy Cover(\%)}

Mean Range Const.

\section{SHRUBS}

WILLOW SPP.

(Salix spp.)

BOG BIRCH

(Betula glandulosa) $\quad 27 \quad 12-40 \quad 100$

\section{FORBS}

SLENDER BLuE BEARdTONGUE

\section{(Penstemon procerus) 3}

BEARBERRY

(Arctostaphylos uva-ursi) 4

SMOOTH LEAVED CINQUEFOIL

(Potentilla diversitolia)

OLD MAN'S WHISKERS

(Geum triflorum) 3

ALPINE GOLDENROD

(Solidago multiradiata)

\section{Grasses}

BOG SEDGE

(Kobresia myosuroides) $26 \quad 16-45 \quad 100$

GRACEFUL SEDGE

(Carex praegracilis) $\quad 16 \quad 0-41 \quad 80$

SLENDER WHEATGRASS

(Agropyron trachycaulum) 9

CALIFORNIA OATGRASS

(Danthonia californica) $\quad 5 \quad 0-12 \quad 80$

\section{ENVIRONMENTAL VARIABLES}

MOISTURE REGIME:

MESIC-SUBHYGRIC

NUTRIENT REGIME:

MESOTROPHIC

ELEVATION:

1791(1530-2286) M

SOIL DRAINAGE:

MODERATELY WELL

SLOPE: $2(1-2) \%$

ASPECT: EASTERLY

ECOLOGICAL STATUS SCORE: 24

\section{Forage Production Kg/HA}

$$
\begin{array}{ll}
\text { GRASS } & 1333(391-2848) \\
\text { FORBS } & 390(88-695) \\
\text { SHRUBS } & 202(0-807) \\
\text { TOTAL } & 1925(683-3416)
\end{array}
$$

ECOLOGICALLY SUSTAINABLE STOCKING RATE

$1.0(1.3-0.5) \mathrm{HA} / \mathrm{AUM}$ OR

0.4(.31-0.8) AUM/AC 


\section{SACFB9. Bog birch-Willow/Rough fescue \\ (Betula glandulosa-Salix spp./Festuca scabrella)}

$\mathbf{n}=4$ This community type is very similar to the Bog birch/Rough fescue-Sedge community described by Willoughby (1992) in the Upper Foothills subregion. Willoughby found that the rough fescue grasslands were located upslope of tufted hairgrass meadows on slightly drier, gravelly soils. Bork (1994), also described rough fescue dominated grasslands in Willmore Wilderness Park. This community type is also similar to the Bog $\mathrm{birch} /$ Rough fescue-Bog sedge community type but lacks the cover of bog sedge. Bog sedge tends to grow at higher elevations and appears to indicate the transition from the Upper Foothills subregion to the Subalpine subregion.

It appears the lack of fire on this community type has allowed the shrub cover to expand, reducing forage productivity for wildlife and domestic livestock. In one study, burning a Bog birch/Rough fescue community type twice in 3 year intervals controlled birch growth and increased total forage production by over $40 \%$ compared to the unburned control in the Upper Foothills subregion (Bork 1990).

\section{Plant Composition Canopy Cover(\%)} Mean Range Const.

\section{SHRUBS}

BOG BIRCH

$\begin{array}{llll}\begin{array}{l}\text { (Betula glandulosa) } \\ \text { WILlOW SPP. }\end{array} & 39 & 24-62 & 100 \\ \text { (Salix spp.) } & 13 & 0-26 & 75\end{array}$

\section{FORBS}

\section{AMERICAN VETCH}

(Vicia americana)

SMOOTH ASTER

(Aster laevis)

TALL LARKSPUR

(Delphinium glaucum)

OLD MAN'S WHISKERS

(Geum triflorum)

FIREWEED

(Epilobium angustifolium) 3

\section{Grasses}

ROUGH FESCUE

(Festuca scabrella) $\quad 19 \quad 10-31 \quad 100$

GRACEFUL SEDGE

(Carex praegracilis) $\quad 6 \quad 1-12 \quad 100$

SLENDER WHEATGRASS

$\begin{array}{lll}\text { (Agropyron trachycaulum) } 9 & 0-33 \quad 60\end{array}$

HAIRY WILDRYE

(Elymus innovatus) $\quad 3 \quad 0-6 \quad 50$

\section{ENVIRONMENTAL VARIABLES}

MOISTURE REGIME:

MESIC

NUTRIENT REGIME: MESOTROPHIC

ELEVATION: 1675(1600-1750) M

SoIL DRAINAGE: WELL

SLOPE:

$5 \%$

ASPECT:

VARIABLE

ECOLOGICAL STATUS SCORE: 24

\section{FORAGE PRODUCTION KG/HA}

GRASS 1807(642-3564)

FORBS 705(492-902)

SHRUBS 559(170-800)

TOTAL 3071(2070-4226)

ECOLOGICALLY SUSTAINABLE STOCKING RATE 1.0(1.3-0.4) HA/AUM OR $0.4(31-1.0) \mathrm{AUM} / \mathrm{AC}$ 


\section{SACFB10. Bog birch/Rough fescue-Bog sedge \\ (Betula glandulosa/Festuca scabrella-Kobresia myosuroides)}

$\mathbf{n}=\mathbf{1}$ This community type is very similar to the Bog birch-Willow/Rough fescue community previously described. Willoughby(2005) found that the rough fescue grasslands were located upslope of tufted hairgrass meadows on slightly drier, gravelly soils. Bork (1994), also described rough fescue dominated grasslands in Willmore Wilderness Park. The presence of bog sedge in this community type appears to indicate the transition from the Upper Foothills and lower Subalpine subregions to the Upper subalpine subregion.

It appears the lack of fire on this community type has allowed the shrub cover to expand, reducing forage productivity for wildlife and domestic livestock. In one study, burning a Bog birch/Rough fescue community type twice in 3 year intervals controlled birch growth and increased total forage production by over $40 \%$ compared to the unburned control in the Upper Foothills subregion (Bork 1990).

\section{Plant Composition Canopy Cover(\%)} Mean Range Const.

\section{SHRUBS}

BOG BIRCH

(Betula glandulosa)

WILLOW SPP.

(Salix barclayi)

30

100

FORBS

FALSE DANDELION

(Agoseris glauca)

GRACEFUL CINQUEFOIL

(Potentilla gracilis)

TALL LARKSPUR

(Delphinium glaucum)

ALPINE GOLDENROD

(Solidago multiradiata)

SHOW LOCOWEED

(Oxytropis splendens)

GRASSES

ROUGH FESCUE

(Festuca scabrella)

GRACEFUL SEDGE

(Carex praegracilis)

SLENDER WHEATGRASS

(Agropyron trachycaulum)34 - $\quad 100$

BOG SEDGE

(Kobresia myosuroides)

100

100

100

100

100

\section{ENVIRONMENTAL VARIABLES}

MOISTURE REGIME:

$$
\text { MesiC }
$$

NUTRIENT REGIME:

MESOTROPHIC

ELEVATION:

$1981 \mathrm{M}$

SOIL DRAINAGE:

WELL

ECOLOGICAL STATUS SCORE: 24

Forage Production KG/HA

GRASS $\quad 1201$

FORBS $\quad 147$

SHRUBS 0

TOTAL 1348

ECOLOGICALLY SUSTAINABLE STOCKING RATE

$1.0(1.3-0.5) \mathrm{HA} / \mathrm{AUM}$ OR

$0.4(.31-0.8) \mathrm{AUM} / \mathrm{AC}$ 


\section{SACFB11. Willow/Fringed brome-Sedge \\ (Salix barclayi/Bromus ciliatus-Carex spp.)}

$\mathbf{n = 1}$ This community was described on the banks of Forbidden Creek west of Rocky Mtn. House where the water table is high but flooding is rare. It occupies the fluvial terraces along the creek. A similar community type Willow/Fringed brome-Slender wheatgrass was described in the Lower Foothills subregion (Lawrence et al. 2005). The production of the Lower Foothills type averaged over $1700 \mathrm{~kg} / \mathrm{ha}$. This community type had only half the production $(760 \mathrm{~kg} / \mathrm{ha})$. The more extreme climatic conditions of this site in the subalpine likely limits the growth of forage.

\section{Plant Composition Canopy Cover(\%)} Mean Range Const.

\section{SHRUBS}

WILLOW SPP.

(Salix barclayi)

50

100

FORBS

YARROW

(Achillea millefolium)

GRACEFUL CINQUEFOIL

(Potentilla gracilis)

ALPINE BISTORT

(Polygonum viviparum)

OLD MAN'S WHISKERS

(Geum triflorum)

8

GRASSES

FRINGED BROME

(Bromus ciliatus)

GRACEFUL SEDGE

(Carex praegracilis)

ROUGH FESCUE

(Festuca scabrella)

SLENDER WHEATGRASS

(Agropyron trachycaulum) 15

100

100

100

\section{ENVIRONMENTAL VARIABLES}

MOISTURE REGIME:

MESIC

NUTRIENT REGIME:

MESOTROPHIC

ELEVATION:

$2286 \mathrm{M}$

SOIL DRAINAGE:

IMPERFECTLY

ECOLOGICAL STATUS SCORE: 24

Forage Production Kg/HA

$\begin{array}{ll}\text { GRASS } & 472 \\ \text { FORBS } & 288 \\ \text { TOTAL } & 760\end{array}$

ECOLOGICALLY SUSTAINABLE STOCKING RATE

1.3(1.8-1.0) HA/AUM OR

$0.31(.22-0.4)$ AUM/AC 


\section{SUBALPINE SUBREGION}

\section{CENTRAL AND NORTHERN ROCKY MOUNTAINS}

\section{NATIVE GRASSLANDS AND SHRUBLANDS}

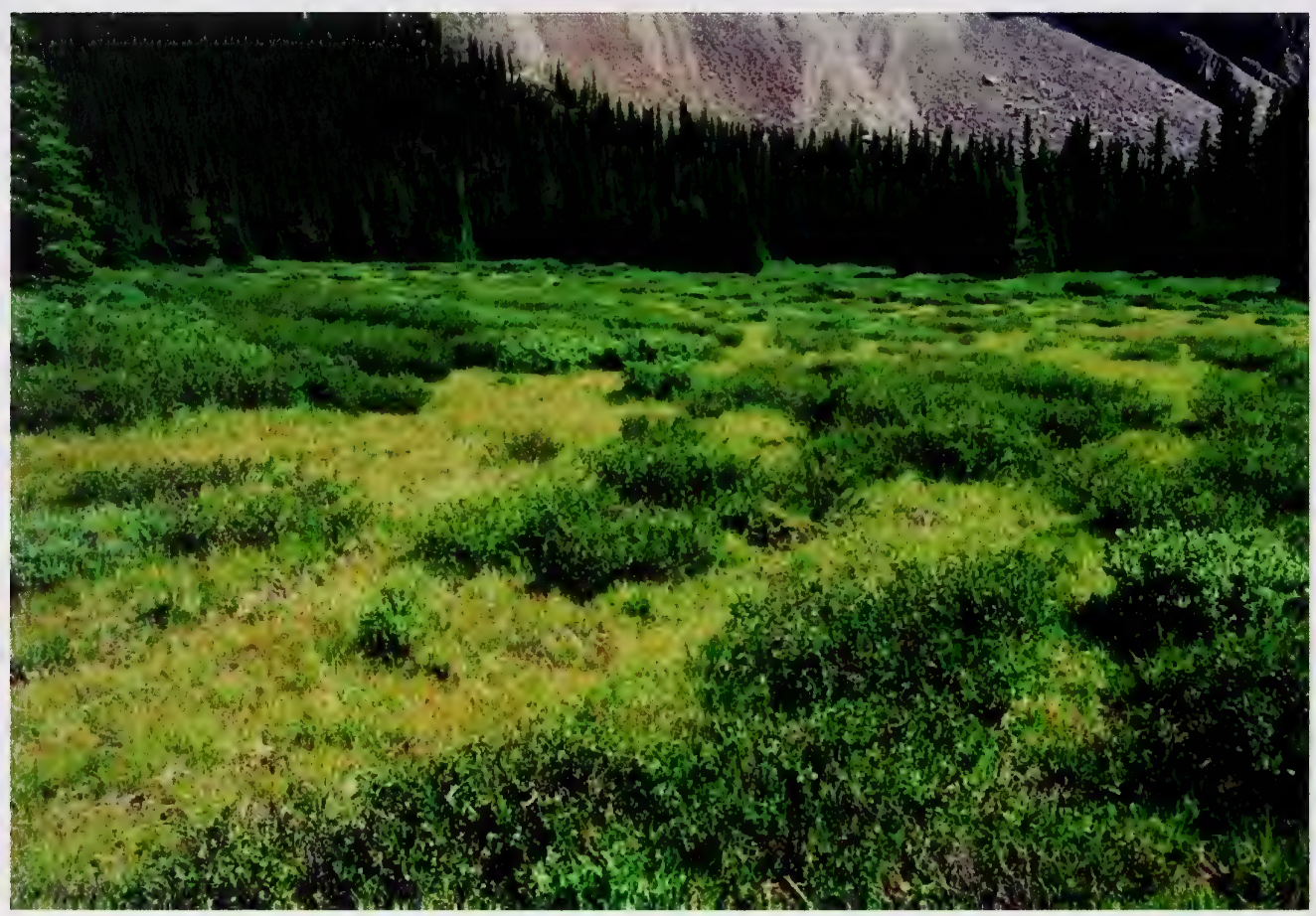

Figure 4. The presence of bog sedge in this Willow-Bog birch/Bog sedge community indicates the transition to the higher and steeper Central and Northern Rocky Mountains of the Subalpine subregion. Note the transition from the Subalpine to Alpine subregions in the background. 


\section{Native grass and shrubland ecology Mountain ecodistricts}

The native grass and shrubland community types in the Central and Northern Rocky Mountains of the Subalpine subregion (Table 3) are found in the valley bottoms adjacent to streams and rivers. The tufted hairgrass, California oatgrass and rough fescue dominated community types described previously in the foothills can also be found in the mountains, but these grassland community types are more common in the foothills and therefore were described in that section of the guide.

There are a number of grassland community types in the Central and Northern Rocky Mountains which are unique and appear to represent a transition from the lower subalpine mountain ecodistricts to the Alpine subregion. These include the hairy wildrye, junegrass and shrubby cinquefoil dominated community types (SACMA3,4,5,6) which are found on steep south facing slopes, at higher elevations throughout the mountains (Figure 2). Near timberline there is a unique forb dominated (globeflower,wandering daisy, mountain marigold, mountain heliotrope) community type found on imperfectly to well drained sites. The presence of bog sedge (Kobresia myosuroides) in the Bog sedge-California oatgrass community type appears to indicate the transition from the lower Central and Northern Rocky Mountains to the Alpine subregion. Ogilvie (1969) and Corns and Achuff (1982), described bog sedge dominated community types in the higher elevations of the subalpine and alpine of the Rocky Mountains of Banff and Jasper National Parks.

The maintenance of the grassland community types in the mountains is extremely fire dependent. The lack of fire quickly allows bog birch and willow to expand shading the modal grassland community types. Prolonged shading causes the understory composition to shift from a tufted hairgrass-California oatgrass dominated understory to a slender wheatgrass-hairy wildrye dominated understory. Under a heavy shrub cover there is little forb or grass cover. The sequence of the grassland and shrubland community types unique to the mountain ecodistricts is outlined in figures 3 and 5. These figures represent the transition from willow, bog birch dominated communities in the valley bottoms to the grass and dwarf shrublands in the upper Subalpine and Alpine subregions.

Many of these subalpine grass and shrublands are very fragile because of exposure and cold climate. The forage productivity is generally only half of what is found in the lower Upper Foothills subregion and recovery from overgrazing will likely take some time because of the poor growing conditions. As a result grazing by domestic livestock should be done with caution. 
Table 3. Native grass and shrublands of the Central and Northern Rocky Mountain ecodistricts of the Subalpine subregion

\begin{tabular}{|c|c|c|c|c|c|c|c|c|}
\hline \multirow{2}{*}{$\begin{array}{l}\text { Community } \\
\text { number }\end{array}$} & \multirow[t]{2}{*}{ Community type } & \multirow[b]{2}{*}{ Grass } & \multicolumn{3}{|c|}{ Productivity (kg/ha) } & \multirow[b]{2}{*}{ Moisture } & \multirow[b]{2}{*}{ Drainage } & \multirow{2}{*}{$\begin{array}{l}\text { Carrying } \\
\text { capacity (ha/AUM) }\end{array}$} \\
\hline & & & Forb & Shrub & Total & & & \\
\hline a1 & shrubby grassland & & & & N/A & Subxeric & Rapidly & 40.0 \\
\hline SACMB5. & Bog birch-Juniper & & & & N/A & Subxeric & Rapidly & 40.0 \\
\hline a2 & graminoid grassland & & & & N/A & Subxeric & Rapidly & 40.0 \\
\hline SACMA7. & Northern wheatgrass & & & & N/A & Subxeric & Rapidly & 40.0 \\
\hline b2 & bearberry grassland & 234 & 155 & 1017 & 1407 & Xeric & Rapidly & 3.0 \\
\hline SACMA4. & Bearberry-Juniper & 234 & 155 & 1017 & 1407 & Xeric & Rapidly & 3.0 \\
\hline bb1 & yellow mtn. avens & & & & N/A & Subxeric & Rapidly & 40.0 \\
\hline SACMA9. & Yellow mountain avens & & & & N/A & Subxeric & Rapidly & 40.0 \\
\hline c4 & hairy wildrye grassland & & & & N/A & Subxeric & Rapidly & 3.5 \\
\hline SACMA3. & Shrubby cinquefoil/Hairy wildrye & & & & N/A & Xeric & Rapidly & 3.0 \\
\hline SACMA5. & Junegrass-Hairy wildrye-Brome & & & & N/A & Subxeric & Rapidly & 4.0 \\
\hline SACMA6. & Hairy wildrye/Bearberry-Juniper & & & & N/A & Mesic & Well & 4.0 \\
\hline d3 & rhododendron-mesic Fa & & & & N/A & Mesic & Well & 40.0 \\
\hline SACMB8. & Subalpine fir & & & & N/A & Mesic & Well & 40.0 \\
\hline d4 & California oatgrass & & & & N/A & Submesic & Well & 22.0 \\
\hline SACMA1. & Bog sedge-California oatgrass & & & & & Mesic & Well & 2.5 \\
\hline SACMA8. & Alpine bluegrass & & & & N/A & Submesic & Well & 40.0 \\
\hline d6 & grouseberry & & & & N/A & Mesic & Well & 40.0 \\
\hline SACMB7. & Grouseberry/Juniper & & & & N/A & Mesic & Well & 40.0 \\
\hline dd2 2 & shrubland & & & & N/A & Subhygric & Mod. well & 2.5 \\
\hline SACMB4. & Willow-Bog birch/Bog sedge & & & & N/A & Subhygric & Mod. well & 2.5 \\
\hline e1 & shrubland & & & & N/A & Subhygric & Mod. well & 1.4 \\
\hline SACMB2. & Willow-Bog birch/Sedge & & & & N/A & Subhygric & Poorly & 1.4 \\
\hline SACMB3. & Willow-Bog birch/Hairy wildrye & & & & N/A & Subhygric & Mod. well & 1.4 \\
\hline
\end{tabular}


Table 3. cont'd

\begin{tabular}{|c|c|c|c|c|c|c|c|c|}
\hline \multirow{2}{*}{$\begin{array}{l}\text { Community } \\
\text { number }\end{array}$} & \multirow[t]{2}{*}{ Community type } & \multicolumn{4}{|c|}{ Production $(\mathrm{kg} / \mathrm{ha})$} & \multirow[b]{2}{*}{ Moisture } & \multirow[b]{2}{*}{ Drainage } & \multirow{2}{*}{$\begin{array}{l}\text { Carrying } \\
\text { capacity (ha/AUM) }\end{array}$} \\
\hline & & Grass & Forb & Shrub & Total & & & \\
\hline SACMB6. & Willow/Forb & & & & N/A & Mesic & Imperfectly & 40.0 \\
\hline e2 & forb meadow & & & & N/A & Mesic to & ricPoorly & 40.0 \\
\hline SACMA2. & Forb meadows & & & & N/A & Mesic to 1 & ricPoorly & 40.0 \\
\hline i2 & shrubby fen & 2320 & 24 & & 2344 & Hygric & Poorly & 40.0 \\
\hline SACMB1. & Willow-Bog birch/Water sedge & 2320 & 24 & & 2344 & Hygric & Poorly & 40.0 \\
\hline
\end{tabular}




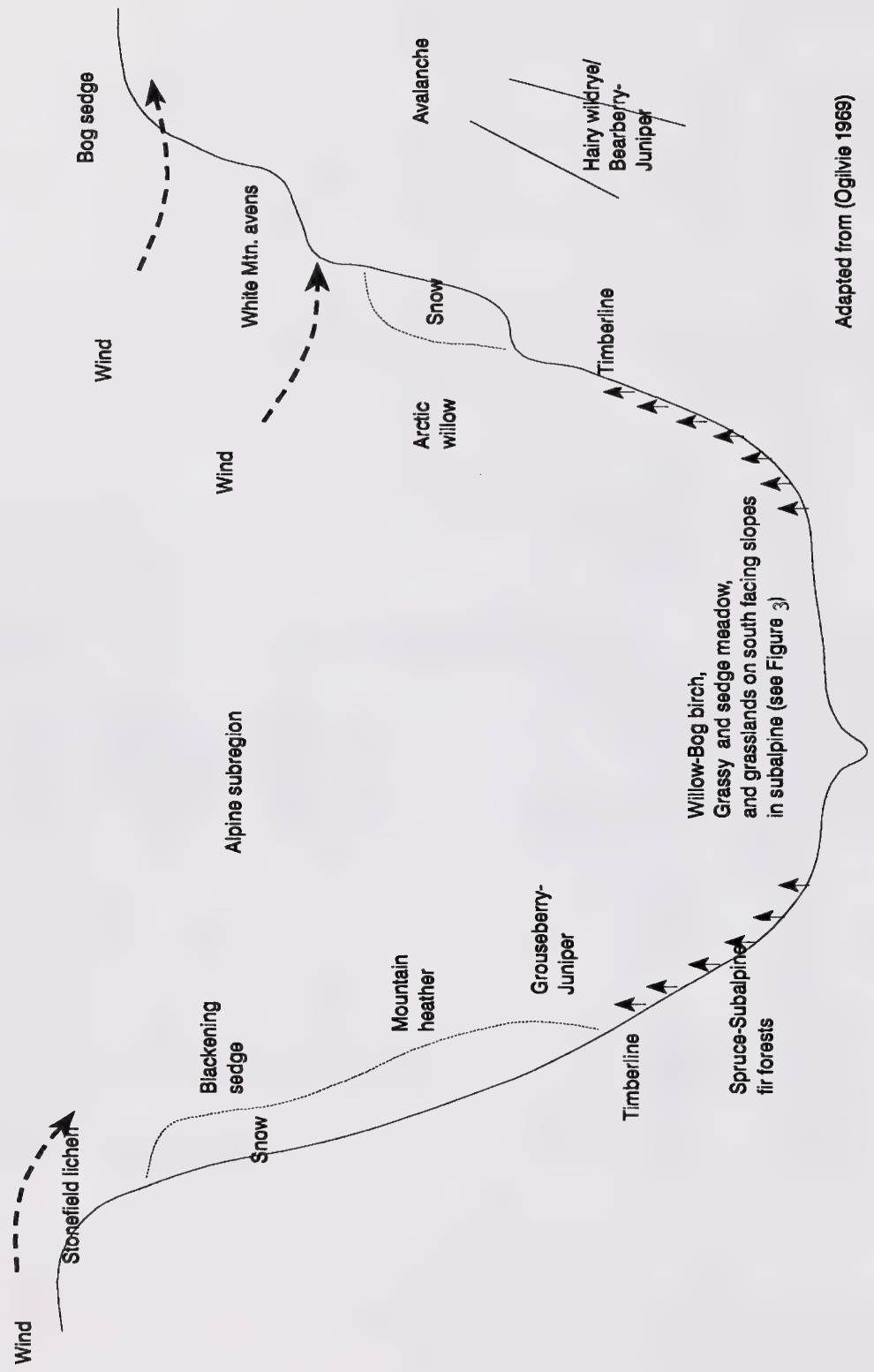

Figure 5. Sequence of plant communities in the Alpine subregion 


\section{Native grass and shrublands in Central and Northern Mountain and Foothills areas}

1. Community above timberline (Alpine subregion)...........Alpine section of guide

Community not above timberline, meadows, shrublands or south facing slopes dominated by shrubs and

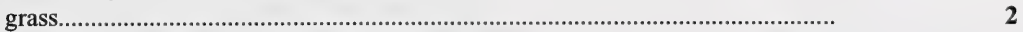

2. Moist sites, community dominated by shrubs $>20 \%$ cover (willow, bog birch) or timberline communities with dwarf trees or grouseberry see shrub key pg 34

Drier to moist sites shrub cover $<10 \%$ site dominated by grasses and forbs.

3

3. Community very wet free standing water, dominated by sedge, cottongrass or tufted bulrush

Community drier, dominated by tufted hairgrass, rough fescue, california oatgrass, hairy wildrye, juniper or bearberry..

4. Very wet nutrient rich sites dominated by water or beaked sedge. SACFA1

Very wet nutrient poor, acidic sites dominated by tufted bulrush and cottongrass...............

5. Site dominated by tufted bulrush.

SACFA2

Site dominated by cottongrass and sedge..

SACFA3

6. Grasslands of meadows and lowland areas.

Grasslands of south facing slopes, or windswept ridges, hairy wildrye, bearberry, white mtn. avens dominated

20

7. Higher elevation sites near or at timberline, moist sites dominated by wandering daisy, globeflower, mountain marigold. SACMA2

Lower elevation sites, valley bottoms adjacent to streams or rivers or if higher elevation dry sites dominated by bog sedge.

8

8. Disturbed or grazed community types dominated by Kentucky bluegrass, creeping red fescue, dandelion, alpine bluegrass, alpine timothy or fireweed

9

Undisturbed community types dominated by rough fescue, California oatgrass, bog sedge, tufted hairgrass, and sedge species...

14

9. Moderately grazed site native increasers dominant (slender wheatgrass, sedge, fringed brome, rocky mtn. fescue, alpine timothy), Alpine or Kentucky bluegrass increasing in cover..

10

Heavily grazed sites dominated by Kentucky bluegrass or abandoned airstrips dominated by creeping red fescue or native

forb species (fireweed, veiny meadow rue)......

10. Site dominated by Alpine bluegrass.

.SACMA8

12

Site dominated by rocky $\mathrm{mtn}$. fescue, alpine timothy, sedge, slender wheatgrass, fringed brome (moister sites)

11. Site dominated by rocky $\mathrm{mtn}$. fescue, alpine timothy, sedge.

Site dominated by slender wheatgrass, sedge, fringed brome

SACFA6

SACFA7

12. Heavily grazed site dominated by Kentucky bluegrass and dandelion.........SACFA16

Abandoned airstrips dominated by creeping red fescue, or invaded strips dominated by forbs (fireweed, veiny meadow).

13 Site dominated by creeping red fescue.

SACFA15

Moister disturbed site dominated by fireweed and veiny meadow rue...SACFA17

14. Moist sites dominated by sedge and tufted hairgrass.

Drier sites dominated by rough fescue, hairy wildrye, bog sedge, yellow dryas or California oatgrass.

15. Site dominated by tufted hairgrass, sedge co-dominant

Site dominated by sedge, tufted hairgrass co-dominant.

SACFA4

SACFA5

16. Sites dominated by rough fescue and hairy wildrye.

SACFA9

Sites dominated by California oatgrass, bog sedge, or yellow dryas

17. Gravelly river flats dominated by yellow dryas.

SACMA9

Meadow areas dominated by California oatgrass and/or bog sedge.

18. Site dominated by bog sedge and california oatgrass.

Site dominated by california oatgrass and sedge, bog sedge not present

SACFA8

19. Site dominated by bog sedge, california oatgrass, drier sites SACMA1

Site co-dominated by bog sedge, tufted hairgrass, and sedge moister sites... SACFA13

20. Lower elevation grasslands in the Foothills of the Subalpine.

Higher elevation grasslands in the mountains of the Subalpine.

21 Northern wheatgrass dominated site.

SACMA7
13 
Fringed sage, sedge and junegrass dominated slope...

SACFA12

22. Avalanche slopes dominated by hairy wildrye, juniper, and bearberry....SACMA6

Drier sites or windswept ridges dominated hairy wildrye, juniper, bearberry, shrubby cinquefoil, white mtn. avens.

SACFA14

23. Windswept ridges dominated by white min. avens.

South facing slopes dominated by hairy wildrye.

24. Shallow rocky soils with little grass cover, site dominated by bearberry.. SACMA4

Deeper soils, good grass cover dominated by hairy wildrye, junegrass.

SACMA3

25. Shrubby cinquefoil dominant in stand

Grass cover extensive, dominated by hairy wildrye, junegrass, and brome....SACMA5

\section{Shrub dominated communities}

1. Timberline communities dominated by whitebark pine, subalpine fir, grouseberry, or willow communities with marsh marigold, wandering daisy or globeflower in understory 2

Riparian communities adjacent to streams or rivers.................................................. $\quad 5$

2. Trees present in community (whitebark pine, subalpine fir) or grouseberry dominated.... 3 Moist seepage areas at treeline dominated by globeflower, wandering daisy or marsh marigold in understory. SACMB6

3. Trees (subalpine fir, whitebark pine) on site SACMB7 Grouseberry dominated shrubland

4. Whitebark pine present. Subalpine fir present..

SACMB3

SACMB8

5. Very wet sites with water sedge or horsetail dominated understories.

Drier sites with tufted hairgrass, california oatgrass, bog sedge, hairy wildrye, rough fescue Kentucky bluegrass, dandelion dominated understories. 7

6. Water sedge dominated understory SACFB1, SACMB1 Horsetail dominated understory SACFB2

7. Grazed communities dominated by clover and dandelion in understory Ungrazed sites dominated by native forbs and grasses in understory. SACFB5

8. Shrubland communities on seepage areas on south facing slopes with shallow soils, dominated by bog birch and juniper. SACMB5

Meadows and lowland shrublands dominated by rough fescue, bog sedge, california oatgrass, tufted hairgrass, hairy wildrye or sedge in the understory.

\section{9}

10

9. Rough fescue dominates the understory. Tufted hairgrass, california oatgrass, bog sedge, sedge, hairy wildrye dominate.

10. Rough fescue and bog sedge dominate understory higher elevations. Rough fescue dominates, bog sedge not present lower elevations

SACFB10

SACFB9

11. Moister sites with deep fluvial deposits dominated by tufted hairgrass, sedge, or fringed brome in understory.

Drier sites which are well drained at the surface dominated by hairy wildrye, sedge, bog sedge or california oatgrass in understory

12. Tufted hairgrass or sedge dominated understory.

Fluvial areas with Fringed brome dominated understory, lower elevation.

SACFB11

13. Tufted hairgrass dominates understory. SACFB4 Graceful sedge and other sedge species dominate understory. SACFB3, SASMB2

14. Modal sites with hairy wildrye and sedge dominating understory. Sites dominated by california oatgrass or bog sedge in understory.

15. Hairy wildrye dominates understory..

Graceful sedge and other sedge species dominate understory.

16. California oatgrass dominates understory.

Bog sedge dominates understory. 


\section{SACMA1. Bog sedge-California oatgrass \\ (Kobresia myosuroides-Danthonia californica)}

$\mathbf{n}=\mathbf{1}$ This community type appears to represent the transition from the foothills ecodistricts to the mountain ecodistricts of the subalpine. It appears that tufted hairgrass, california oatgrass and rough fescue all decline and bog sedge increases as there is an increase in elevation and change from the foothills to the mountains.

This community type is found on level to gently sloping valley bottoms with mesic moisture regimes. The presence of California oatgrass maybe indicative of a well drained, gravelly site. In the Yukon the California oatgrass dominated community types were found to form in depressions which appeared to act as pronounced frost pockets (Bailey et al. 1992). Bog sedge also appears to be adapted to these site condition (Oglivie 1969).

\section{Plant Composition Canopy Cover(\%)} Mean Range Const.

\section{SHRUBS}

WILLOW

(Salix spp.)

SHRUBBY CINQUEFOIL

(Potentilla fruticosa)

2

25

\section{FORBS}

BEARBERRY

(Arctostaphylos uva-ursi) $15 \quad$ - 100

YARROW

(Achillea millefolium) 1

SMALL LEAVED EVERLASTING

(Antennaria parviflora) 1

GRASSES

CALIFORNIA OATGRASS

(Danthonia californica) $35 \quad$ - $\quad 100$

BOG SEDGE

(Kobresia myosuroides) $25 \quad \ldots \quad-100$

\section{ENVIRONMENTAL VARIABLES}

MOISTURE REGIME:

MESIC

NUTRIENT REgIME:

MESOTROPHIC

ELEVATION:

$1850 \mathrm{M}$

SOIL DRAINAGE:

WELL

ECOLOGICAL STATUS SCORE: 24

Forage PRODUCTION KG/HA

ECOlOGICALly SUSTAINABLE STOCKING RATE GENERALLY NON-USE

2.5(40.0-2.0) HA/AUM

$0.16(.01-0.2) \mathrm{AUM} / \mathrm{AC}$ 


\section{SACMA2. Forb meadows}

(Trollius albiflorus, Erigeron peregrinus, Anemone occidentalis, Caltha leptosepala)

$\mathbf{n}=17$ These forb dominated meadows include both the Caltha leptosepala-Trollius albiflorus and Erigeron peregrinus-Valeriana sitchensis community types described by Corns and Achuff (1982). These meadows occupy mesic to hygric, gently sloping, upper subalpine to alpine areas. The soils are imperfectly to well drained Gleysols on fluvial and morainal landforms. On the poorly to imperfectly drained sites in areas where snow melts late and seepage is received throughout the growing season mountain marigold and globeflower predominate. In contrast on better drained, drier sites fleabane and mountain heliotrope predominate.

\section{Plant Composition Canopy Cover(\%)} mean Range Const.

SHRUBS

ARCTIC WILLOW

(Salix arctica)

WESTERN MOUNTAIN HEATHER

(Cassiope mertensiana) 3

\section{FORBS}

WANDERING DAISY

(Erigeron peregrinus)

WOOLY EVERLASTING

(Antennaria lanata)

GLOBEFLOWER

(Trollius albiflorus)

MOUNTAIN HELIOTROPE

(Valeriana sitchensis)

MOUNTAIN MARIGOLD

(Caltha leptosepala)

CHALICEFLOWER

(Anemone occidentalis)

GRASSES

BLACKENING SEDGE

(Carex nigrescens)

MOUNTAIN TIMOTHY

(Phleum commutatum)

SEDGE

(Carex spectabilis)
$0-5 \quad 59$

$0-10 \quad 47$

$9 \quad 0-10 \quad 88$

$4 \quad 0-35 \quad 65$

$13 \quad 0-40 \quad 82$

$9 \quad 0-20 \quad 82$

$5 \quad 0-23 \quad 53$

$0-20 \quad 70$

$\begin{array}{lll}7 & 0-20 & 70\end{array}$

$2 \quad 0-20 \quad 35$

$0-2 \quad 41$

$0-10 \quad 23$

\section{ENVIRONMENTAL VARIABLES}

MOISTURE REGIME:

MESIC TO HYGRIC

NUTRIENT REGIME:

PERMESOTROPHIC

ELEVATION:

$2024(1850-2300) \mathrm{M}$

SOIL DRAINAGE:

IMPERFECTLY TO WELL

SLOPE:

$27(3-55) \%$

ASPECT:

VARIABLE

ECOLOGICAL STATUS SCORE: 24

Forage Production Kg/HA

Ecologically Sustainable Stocking Rate GENERALLY NON-USE $40.0(40.0-1.0) \mathrm{HA} / \mathrm{AUM}$

$.01(.01-0.4) \mathrm{AUM} / \mathrm{AC}$ 


\section{SACMA3. Shrubby cinquefoil/Hairy wildrye \\ (Potentilla fruticosa/Elymus innovatus)}

$\mathbf{n = 5}$ Corns and Achuff (1982), described this community type on subxeric to xeric, south facing slopes in Banff and Jasper. The soils are rapidly to well drained Regosols on colluvial, eolian and glacial landforms. On more stable sites they felt succession would be to a Lodgepole pine/Juniper/Bearberry community type.

\section{Plant Composition Canopy Cover(\%)} Mean Range Const.

\section{SHRUBS}

SHRUBBY CINQUEFOIL.

(Potentilla fruticosa) $\quad 20 \quad 4-40 \quad 100$

BOG BIRCH

(Betula glandulosa) $\quad 2 \quad 0-5 \quad 40$

FORBS

BEARBERRY

(Arctostaphylos uva-ursi) $1 \quad 0-3 \quad 20$

WHITE MOUNTAIN AVENS

(Dryas integrifolia) $\quad 3 \quad 0-15 \quad 20$

STRAWBERRY

(Fragaria virginiana) 6

ALPINE FORGET-ME-KNOT

(Myosotis alpestris) 5

SWEET-FLOWERED ANDROSACE

(Androsace chamaejasme 4

WANDERING DAISY

(Erigeron peregrinus) 2

SPOTTED SAXIFRAGE

(Saxifraga bronchialis) 3

\section{GRASSES}

HAIRY WILDRYE

(Elymus innovatus)

BLUNT SEDGE

(Carex obtusata)

NORWAY SEDGE

(Carex norvegica)

BROAD GLUMED WHEATGRASS

(Agropyron violaceum) 5

\section{ENVIRONMENTAL VARIABLES}

MOISTURE REGIME:

XERIC-SUBXERIC

NUTRIENT REGIME:

SUBMESOTROPHIC

ELEVATION:

$$
1720(1500-1800) \mathrm{M}
$$

SOIL DRAINAGE:

RAPIDLY

SLOPE:

$$
28(15-55) \%
$$

ASPECT:

SOUTHERLY

ECOLOGICAL STATUS SCORE: 24

Forage Production Kg/HA

NoT AVAILABLE

ECologically SustainABLE Stocking RATE GENERALLY NON-USE

3.5(40.0-3.0) HA/AUM

$0.11(.01-.13) \mathrm{AUM} / \mathrm{AC}$ 


\section{SACMA4. Bearberry-Juniper \\ (Arctostaphylos uva-ursi-Juniperus communis)}

$\mathbf{n = 1 4}$ This community type is very similar to the previously describe Shrubby cinquefoil/Hairy wildrye dominated community type. Both community types occupy rapidly drained, steep south facing slopes. This community type is distinguished from the Shrubby cinquefoil community type by the presence of a high cover of bearberry and juniper and a low cover of shrubby cinquefoil. This community type is much drier than the shrubby cinquefoil type and is located on much steeper slopes.

\section{Plant Composition Canopy Cover(\%)} Mean Range Const.

\section{SHRUBS}

SHRUBBY CINQUEFOIL

(Potentilla fruticosa)

GROUND JUNIPER

(Juniperus communis)

SMOOTH WILLOW

(Salix glauca)

$\begin{array}{lll}3 & 0-18 & 72 \\ 9 & 0-25 & 92 \\ 2 & 0-10 & 43\end{array}$

FORBS

STRAWBERRY

(Fragaria virginiana) $\quad 1 \quad 0-3 \quad 64$

WHITE CAMUS

(Zigadenus elegans)

MOUNTAIN VALERIAN

(Valeriana sitchensis)

HARE BELL

(Campanula rotundifolia)

TWINFLOWER

(Linnaea borealis)

BEARBERRY

(Arctostaphylos uva-ursi)

19

8-55 100

\section{GRASSES}

HAIRY WILDRYE

(Elymus innovatus)

SPIKED TRISETUM

(Trisetum spicatum) $\quad \mathrm{T} \quad 0-1 \quad 21$

JUNEGRASS

(Koeleria macrantha) $\quad 1 \quad 0-5 \quad 43$

SEDGE SPP.

(Carex spp.)

$\begin{array}{ccc}2 & 0-10 & 50 \\ \mathrm{~T} & 0-1 & 21 \\ 1 & 0-5 & 43 \\ 1 & 0-6 & 54\end{array}$

\section{ENVIRONMENTAL VARIABLES}

MOISTURE REGIME:

XERIC-SUBXERIC

NUTRIENT REGIME:

SUBMESOTROPHIC

ELEVATION:

1901(1700-2000) M

SOIL DRAINAGE:

RAPIDLY

SLOPE:

$60(55-71) \%$

ASPECT:

SOUTHERLY

ECOLOGICAL STATUS SCORE: 24

Forage Production Kg/Ha
GRASS $234(163-312)$
FORB $155(97-176)$
SHRUB 1017 (0-1743)
TOTAL 1407 (488-2003)

ECologically Sustainable Stocking Rate GENERALLY NON-USE 3.0(40.0-2.5)HA/AUM $.13(.01-.16)$ AUM/AC 


\section{SACMA5. Junegrass-Hairy wildrye-Brome \\ (Koeleria macrantha-Elymus innovatus-Bromus inermis)}

$\mathbf{n}=\mathbf{2 2}$ This community type was described by Corns and Achuff (1982) on subxeric, steep south facing slopes in the Front ranges east of Banff and Jasper. It is very similar to the bearberry and shrubby cinquefoil community types previously described, but this community type has better developed soils (Brunisols) than the Regosolic soils of the other community types.

This community type is also similar to the Pasture sagewort/Junegrass and Junegrass-Plains reed grass community types described by Willoughby et al (2005) and Stringer (1973) in the lower Montane subregion and the Junegrass/Sage community type described in the Upper Foothills subregion (Willoughby 2005). The high elevations of this community distinguishes this community type from the lower elevation grasslands (Corns and Achuff 1982).

\section{Plant Composition Canopy Cover(\%) Mean Range Const.}

SHRUBS

SHRUBBY CINQUEFOIL

(Potentilla fruticosa)

$0-6 \quad 59$

\section{FORBS}

SLENDER BLUE BEARDTONGUE

\begin{tabular}{|c|c|}
\hline (Penstemon procerus) & $0-2$ \\
\hline YARROW & \\
\hline (Achillea millefolium) & $0-15$ \\
\hline $\begin{array}{l}\text { SHOWY LOCOWEED } \\
\text { (Oxytropis splendens) }\end{array}$ & $0-15$ \\
\hline BEARBERRY & \\
\hline (Arctostaphylos uva-ursi) 1 & $0-10$ \\
\hline $\begin{array}{l}\text { YELLOW HEDYSARUM } \\
\text { (Hedysarum sulphurscens) } 5\end{array}$ & $0-15$ \\
\hline SMALL LEAVED EVERLASTI & \\
\hline (Antennaria parviflora) & $0-15$ \\
\hline
\end{tabular}

GraSSES

ROCKY MOUNTAIN FESCUE

(Festuca saximontana) T

JUNEGRASS

(Koeleria macrantha) $15 \quad 0-35 \quad 96$

HAIRY WILDRYE

(Elymus innovatus) $\quad 17 \quad 0-55 \quad 82$

SEDGE

(Carex spp.)

$1 \quad 0-10$

54

BROME

(Bromus inermis)

\section{ENVIRONMENTAL VARIABLES}

MOISTURE REGIME:

XERIC-SUBXERIC

NUTRIENT REGIME:

SUBMESOTROPHIC

ELEVATION:

1964(1910-2100) M

SOIL DRAINAGE:

RAPIDLY

SLOPE:

$49(40-56) \%$

ASPECT:

SOUTHERLY

ECOLOGICAL STATUS SCORE: 24

Forage Production KG/HA

ECOlOGICALly SUSTAINABLE STOCKING RATE GENERALLY NON-USE

4.0(40.0-2.0) HA/AUM

$0.1(.01-0.2) \mathrm{AUM} / \mathrm{AC}$ 


\section{SACMA6. Hairy wildrye/Bearberry-Juniper \\ (Elymus innovatus/Arctostaphylos uva-ursi-Juniperus communis)}

n=36 Ogilvie (1969) and Corns and Achuff (1982), described this community type on steep south-facing slopes, with stoney, black soils. This community type is also subjected to frequent snow avalanching, particularly during the spring when the snow is melting. This community type is moister than the junegrass, bearberry and shrubby cinquefoil communities previously described. This is likely the result of the increased snow cover. The soils are Melanic Brunisols and Humic Regosols, which are better developed than the drier community types previously described.

\section{Plant Composition Canopy Cover(\%)} Mean Range Const.

\section{SHRUBS}

JUNIPER

$\begin{array}{cccc}\begin{array}{c}\text { (Juniperus communis) } \\ \text { SHRUBBY CINQUEFOIL }\end{array} & 6 & 0-30 & 63 \\ \text { (Potentilla fruticosa) } & 3 & 0-24 & 44\end{array}$

FORBS

BEARBERRY

(Arctostaphylos uva-ursi) $16 \quad 0-60 \quad 76$

WILD STRAWBERRY

(Fragaria virginiana) $2 \quad 0-15 \quad 74$

WHITE CAMAS

(Zigadenus elegans) $\quad 1 \quad 0-7 \quad 39$

FIREWEED

(Epilobium angustifolium) $1 \quad 0-5 \quad 46$

TWINFLOWER

(Linnaea borealis)

YELLOW HEDYSARUM

(Hedysarum sulphurscens) 3

GRASSES

HAIRY WILDRYE

(Elymus innovatus)

JUNEGRASS

(Koeleria macrantha) $1 \quad 0-5 \quad 28$

CALIFORNIA OATGRASS

(Danthonia californica) $15 \quad 0-40 \quad 13$

RED FESCUE

(Festuca rubra)

SPIKED TRISETUM

(Trisetum spicatum)
$44 \quad 0-70 \quad 98$

$1 \quad 0-30 \quad 2$

$1 \quad 0-5 \quad 28$

\section{ENVIRONMENTAL VARIABLES}

MOISTURE REGIME:

MESIC

NUTRIENT REGIME:

PERMESOTROPHIC

ELEVATION:

1942(1380-2300)M

SOIL DRAINAGE:

WELL

SLOPE:

$52(0-80) \%$

ASPECT:

SOUTH

ECOLOGICAL STATUS SCORE: 24

Forage Production Kg/HA

Ecologically Sustainable Stocking Rate GENERALLY NON-USE

4.0(40.0-2.5) HA/AUM $.1(.01-.16) \mathrm{AUM} / \mathrm{AC}$ 


\section{SACMA7. Northern wheatgrass \\ (Agropyron dasystachyum)}

$\mathbf{n = 3}$ This community type occurs on steep south facing slopes, with shallow soils, at lower elevations in the subalpine. It is very similar to the northern wheatgrass community type described by Willoughby et al. (2005) and Corns and Achuff (1982) in the Montane subregion of Banff and Jasper. This community type is distinguished from the other hairy wildrye, junegrass, bearberry and shrubby cinquefoil community types by the presence of northern wheatgrass and the lower elevations. The inaccessibility and fragile nature of the soils make this community type unsuitable for grazing.

\section{Plant COMPOSITION CANOPY COVER(\%) Mean Range Const. \\ SHRUBS}

PRICKLY ROSE

(Rosa acicularis)

$1 \quad 0-1$

67

FORBS

BEARBERRY

(Arctostaphylos uva-ursi) T

SHOWY LOCOWEED

(Oxytropis splendens) 1

FIREWEED

(Epilobium angustifolium)2

WESTERN MEADOW RUE

(Thalictrum occidentalis) 6

COMMON YARROW

(Achillea millefolium)

GraSSES

JUNEGRASS

(Koeleria macrantha) 3

ALPINE TIMOTHY

(Phleum commutatum) 1

BLUNT SEDGE

(Carex obtusata)

HAIRY WILDRYE

(Elymus innovatus)

NORTHERN WHEATGRASS

(Agropyron dasystachyum) 30

$0-5 \quad 67$

\section{ENVIRONMENTAL VARIABLES}

MOISTURE REGIME:

SUBXERIC-XERIC

NUTRIENT REGIME:

SUBMESOTROPHIC

SLOPE:

$$
31(30-60) \%
$$

ASPECT:

\section{SOUTHERLY}

ELEVATION:

$1720(1220-1859) \mathrm{M}$

SOIL DRAINAGE:

RAPIDLY

ECOLOGICAL STATUS SCORE: 24

Forage Production Kg/Ha

TOTAL $\quad 400 *$ EsTIMATE

ECOLOGICALLY SUSTAINABLE STOCKING RATE GENERALLY NON-USE 40.0(40.0-4.0)HA/AUM

.01(.01-0.1) AUM/AC 


\section{SACMA8. Alpine bluegrass \\ (Poa alpina)}

$\mathbf{n = 1}$ The ecology of this community type is unclear. It was described on a gentle, easterly slope in the lower subalpine. Alpine bluegrass is known to grow in meadows, tundra and rocky slopes and is often abundant where the ground has been compacted (MacKinnon et al. 1992). It is possible that this community type could have been described adjacent to a game or hiking trail.

\section{Plant Composition Canopy Cover(\%) Mean Range Const.}

\section{SHRUBS}

DWARF BILBERRY

(Vaccinium caespitosum) $6 \quad-\quad 100$

SHRUBBY CINQUEFOIL

(Potentilla fruticosa)

4

\section{FORBS}

STRAWBERRY

$\begin{array}{llll}\text { (Fragaria virginiana) } \quad 20 & - & 100\end{array}$

FIREWEED

(Epilobium angustifolium)4 $\quad$ - $\quad 100$

BALSAM GROUNDSEL

$\begin{array}{lll}\text { (Senecio pauperculus) } & 3 & -\end{array}$

\section{Grasses}

ALPINE BLUEGRASS

(Poa alpina) $\quad 45 \quad-\quad 100$

ROCKY MOUNTAIN FESCUE

$\begin{array}{llll}\text { (Fescue brachyphylla) } & 1 & - & 100\end{array}$

\section{ENVIRONMENTAL VARIABLES}

MOISTURE REGIME:

SUBMESIC

NUTRIENT REGIME:

SUBMESOTROPHIC

ELEVATION:

$1800 \mathrm{M}$

SOIL DRAINAGE:

WELL

SLOPE:

$4 \%$

ASPECT:

EASTERLY

ECOLOGICAL STATUS SCORE: 18

Forage Production Kg/HA
ECOlOGICALly Sustainable Stocking RATE GeNERALLY NON-USE 40.0(40.0-3.0)HA/AUM $.01(.01-.13) \mathrm{AUM} / \mathrm{AC}$ 


\section{SACMA9. Yellow mountain avens}

\section{(Dryas drummondil)}

$\mathbf{n = 4}$ Corns and Achuff (1982), described this community type on recent fluvial and glacialfluvial landforms with gentle slopes. The soils are rapidly drained. Willoughby et al. (2005), described a yellow mountain avens community type on dry, gravelly river flats with nutrient poor soils in the Montane subregion. They found this community type to be successionally immature and succession would be to a Balsam poplar dominated community type.

\section{Plant Composition Canopy Cover(\%)}

Mean Range Const.

\section{SHRUBS}

YELLOW MOUNTAIN AVENS

(Dryas drummondii) 50

WILLOW SPP.

(Salix spp.)$$
5
$$$$
25-50
$$$$
100
$$

FORBS

ALPINE GOLDENROD

(Solidago multiradiata)

BROAD LEAVED FIREWEED

(Epilobium latifolium)

SHOWY LOCOWEED

(Oxytropis splendens)

$$
1
$$

$0-3$

Grasses

SEDGE

(Carex spp)

\section{ENVIRONMENTAL VARIABLES}

MOISTURE REGIME:

SUBXERIC

NUTRIENT REGIME:

MESOTROPHIC

ELEVATION:

$1542(1450-1670) \mathrm{M}$

SOIL DRAINAGE:

RAPIDLY

ECOLOGICAL STATUS SCORE: 24

Forage Production Kg/HA
ECOLOGICALly SUSTAINABle STOCKING RATE GENERALLY NON-USE (40.0(40.0-8.5) HA/AUM $.01(.01-0.04) \mathrm{AUM} / \mathrm{AC}$ 


\section{SACMB1. Willow/Water sedge \\ (Salix spp./Carex aquatilis)}

$\mathbf{n}=\mathbf{2 3}$ This shrub community appears on areas with very poor drainage. It is found in association with the wetter water sedge meadows. These sites are fairly productive but difficult to graze due to the moist ground conditions and heavy shrub cover which reduces access and mobility within the area. Increased flooding and prolonged waterlogging may result in the disappearance of willow and a transition to a water sedge meadow.

This community is similar to the water sedge-beaked sedge community in that it is found throughout the foothills and into the mountains. It maybe found in the Upper Foothills, Subalpine and lower Alpine subregions.

\section{Plant Composition Canopy Cover(\%)} mean Range Const.

SHRUBS

WILLOW

(Salix spp)

BOG BIRCH

(Betula glandulosa)

$27 \quad 0-75 \quad 96$

$\begin{array}{lll}7 \quad 0-38 & 70\end{array}$

FORBS

ELEPHANT'S HEAD

(Pedicularis groenlandicum) $1 \quad 0-7 \quad 30$

DWARF RASPBERRY

(Rubus arcticus)

ALPINE BISTORT

(Polygonum viviparum)

WANDERING DAISY

(Erigeron peregrinus)

GRASSES

WATER SEDGE

(Carex aquatilis)

$50 \quad 15-80 \quad 100$

TUFTED HAIRGRASS

(Deschampsia cespitosa) $3 \quad 0-30 \quad 26$

SEDGE

(Carex spp.)

BALTIC RUSH

(Juncus balticus)

T $\quad 0-1 \quad 4$

\section{ENVIRONMENTAL VARIABLES}

MOISTURE REGIME:

SUBHYGRIC-HYGRIC

NUTRIENT REGIME:

PERMESOTROPHIC

ELEVATION:

1747(1340-1970) M

SOIL DRAINAGE:

POORLY

ECOLOGICAL STATUS SCORE: 24

Forage Production KG/HA

GRASS 2320

FORBS 24

TOTAL 2344

ECOLOGICALLY SUSTAINABLE STOCKING RATE

GENERALLY NON-USE

40.0(40.0-1.0) HA/AUM

.01(.01-0.4) AUM/AC 


\section{SACMB2. Willow-Bog birch/Sedge \\ (Salix glauca-Betula glandulosa/Carex spp.)}

$\mathbf{n = 2 1}$ This community type is found in association with the Tufted hairgrass-Sedge or California oatgrass community type. Willow encroachment into grassland meadows eventually results in this community type. Historically fire has played an important role in the maintenance of the grassland community type in this subregion. Continued fire suppression will eventually allow willow and bog birch to invade many of the grassy meadows.

This community type is slightly drier than the Willow/Water sedge dominated community type.

\section{Plant CoMposition CANOPY}

\section{COVER(\%)}

\section{SHRUBS}

SMOOTH WILLOW .

\section{(Salix glauca)}

BARRET'S WILLOW

(Salix barrattiana)

BOG BIRCH

(Betula glandulosa)

\section{FORBS}

YARROW

(Achillea millefolium)

WILD STRAWBERRY

(Fragaria virginiana)

WANDERING DAISY

(Erigeron peregrinus)

MOUNTAIN HELIOTROPE

(Valeriana sitchensis)

GLOBEFLOWER

(Trollius albiflorus)

WOOLLY EVERLASTING

(Antennaria lanata)

\section{Mean Range Const.}

$\begin{array}{lll}11 & 0-30 & 67 \\ 15 & 0-55 & 71 \\ 12 & 0-30 & 81\end{array}$

\section{Grasses}

TUFTED HAIRGRASS

(Deschampsia cespitosa)

CALIFORNIA OATGRASS

(Danthonia californica)

SEDGE

(Carex spp.)
$0-4$

29

0-10

19

$23 \quad 0-73 \quad 95$

$0-5 \quad 23$

$0-7 \quad 38$

0-12 33

\section{ENVIRONMENTAL VARIABLES}

MOISTURE REGIME:

MESIC -HYGRIC

NUTRIENT REGIME:

PERMESOTROPHIC

ELEVATION:

1793(1370-2110) M

SOIL DRAINAGE:

MOD. WELL

ECOLOGICAL STATUS SCORE: 24

Forage Production Kg/HA

ECOLOGICALLY SUSTAINABLE STOCKING RATE GENERALLY NON-USE

1.4(1.8-1.0) HA/AUM

$.28(.22-0.4) \mathrm{AUM} / \mathrm{AC}$ 


\section{SACMB3. Willow-Bog birch/Hairy wildrye \\ (Salix glauca-Bog birch/Elymus innovatus)}

$\mathbf{n}=17$ This community is typical of the valley bottoms where the low temperatures prohibit the growth of trees. Corns and Achuff (1982) described a similar community in the Banff and Jasper National Parks. They found this community type occupied coarse stream deposits which had repeated flooding.

Bork (1994) felt this community type developed from the invasion of willow and bog birch onto grasslands in the absence of disturbance in Willmore Wilderness park. Willow cover has increased, shading the growth of grasses and allowing tall-growing forbs, such as fireweed, aster and veiny meadow rue to increase. He felt continued protection from disturbance will allow succession to shrub and eventually tree species. This community is typical of the valley bottoms throughout the subalpine in both the foothills and mountain ecodistricts.

\section{Plant Composition Canopy Cover(\%)} Mean Range Const.

TREES

ENGELMANN SPRUCE

(Picea engelmannii)

SHRUBS

WILLOW SPP.

(Salix glauca)

BOG BIRCH

(Betula glandulosa)

SHRUBBY CINQUEFOIL

(Potentilla fruticosa)

FORBS

NORTHERN VALERIAN

(Valeriana dioica)

YARROW

(Achillea millefolium)

FIREWEED

(Epilobium angustifolium) $3 \quad 0-20 \quad 59$

STRAWBERRY

$\begin{array}{llll}\text { (Fragaria virginiana) } \quad 5 & 0-20 \quad 82\end{array}$

TALL LARKSPUR

(Delphinium glaucum) $3 \quad 0-10 \quad 65$

VEINY MEADOW RUE

(Thalictrum venulosum)

\section{GRASSES}

BOG SEDGE

(Kobriesia myosuroides) $1 \quad 0-13 \quad 12$

HAIRY WILDRYE

(Elymus innovatus) $\quad 17 \quad 0-50 \quad 94$

SEDGE

(Carex spp)

$1 \quad 0-5$

TUFTED HAIR GRASS

T $\quad 0-2 \quad 6$

\section{ENVIRONMENTAL VARIABLES}

MOISTURE REGIME: SUBHYGRIC

NUTRIENT REGIME: MESOTROPHIC

ELEVATION: 1859(1400-2240) M

SOIL DRAINAGE:

WELL TO MODERATELY WELL

ECOLOGICAL STATUS SCORE: 24

Forage Production KG/HA

ECOLOGICALLY SUSTAINABLE STOCKING RATE GENERALLY NON-USE 1.4(1.8-1.0) HA/AUM $.28(.04-.22) \mathrm{AUM} / \mathrm{AC}$

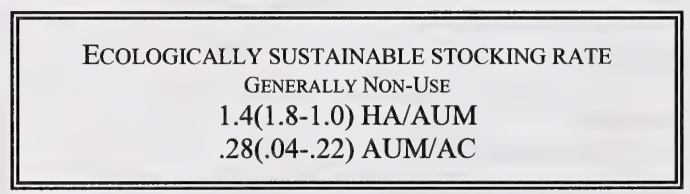




\section{SACMB4. Willow-Bog birch/Bog sedge \\ (Salix spp.-Betula glandulosa/Kobresia myosuroides)}

$\mathbf{n = 1 4}$ This community type was described on moist lowland sites at higher elevations in the Central and Northern Rocky Mountain ecodistricts. It appears this community type originated from recent shrub encroachment onto sedge-bog sedge-tufted hairgrass community type. The presence of bog sedge may represent the transition between the foothills ecodistricts and the rocky mountain ecodistricts. Corns and Achuff (1982) described bog sedge dominated community types in the Central and Northern Rocky Mtn. ecodistricts of the Subalpine subregion of Banff and Jasper National Parks.

\section{Plant Composition CANOPY COVER(\%)}

\section{SHRUBS}

\section{Mean Range Const.}

WILLOW SPP.

(Salix spp.)
BOG BIRCH

(Betula glandulosa)

SHRUBBY CINQUEFOIL

(Potentilla fruticosa)

$0-55$

93

$15 \quad 0-55 \quad 71$

$7 \quad 0-20 \quad 79$

FORBS

ALPINE BISTORT

(Polygonum viviparum)

$0-5 \quad 64$
BEARBERRY

(Arctostaphylos uva-ursi) 3

SMOOTH LEAVED CINQUEFOIL

(Potentilla diversitolia) 1

ALPINE HEDYSARUM

STRAWBERRY

$\begin{array}{llll}\text { (Fragaria virginiana) } & 3 & 0-15 & 71\end{array}$

GraSSES

BOG SEDGE

(Kobresia myosuroides) 2

SEDGE

(Carex spp.)

$0-15 \quad 50$

$0-10 \quad 29$

$0-15 \quad 71$

TUFTED HAIRGRASS

(Deschampsia cespitosum) 2

CALIFORNIA OATGRASS

(Danthonia californica) 2
$7-45 \quad 100$

$0-4 \quad 71$

$0-10 \quad 29$

$0-10 \quad 21$

\section{ENVIRONMENTAL VARIABLES}

MOISTURE REGIME:

MESIC-SUBHYGRIC

NUTRIENT REGIME:

MESOTROPHIC

ELEVATION:

1901(1700-2280) M

SOIL DRAINAGE:

MODERATELY WELL

ECOLOGICAL STATUS SCORE: 24

Forage Production KG/HA

ECOLOGICALLY SUSTAINABLE STOCKING RATE GENERALLY NON-USE 2.5(40.0-2.0)HA/AUM $.16(.01-0.2) \mathrm{AUM} / \mathrm{AC}$ 


\section{SACMB5. Bog birch/Juniper \\ (Betula glandulosa/Juniperus communis)}

$\mathbf{n}=\mathbf{5} \quad$ This community type is found on rocky exposures with westerly aspects in association with Engelmann spruce and lodgepole pine forests. The soils are very shallow and rapidly drained.

Plant Composition Canopy Cover(\%) Mean Range Const.

SHRUBS

BOG BIRCH

(Betula glandulosa)

$29 \quad 20-80 \quad 100$

COMMON JUNIPER

(Juniperus communis)

8

$0-20 \quad 80$

FORBS

YARROW

(Achillea millefolium)

FIREWEED

(Epilobium angustifolium)2

TALL LARKSPUR

(Delphinium glaucum)

MOUNTAIN SAGE

(Artemisia norvegica)

TWINFLOWER

(Linnaea borealis)

BEARBERRY

(Arctostaphylos uva-ursi)

\section{GRASSES}

ROCKY MOUNTAIN FESCUE

(Festuca brachyphylla) T

SEDGE

(Carex spp.)

HAIRY WILDRYE

(Elymus innovatus)

T $\quad 0-1 \quad 20$

$2 \quad 0-3 \quad 80$

$4 \quad 0-15 \quad 40$

\section{ENVIRONMENTAL VARIABLES}

MOISTURE REGIME:

SUBXERIC

NUTRIENT REGIME:

MESOTROPHIC

ELEVATION:

1998(1900-2130) M

SOIL DRAINAGE:

RAPIDLY

SLOPE:

$35(10-50) \%$

ASPECT:

WESTERLY

ECOLOGICAL STATUS SCORE: 24

Forage Production Kg/HA

ECOLOGICALLY SUSTAINABLE STOCKING RATE GENERALLY NON-USE 40.0(40.0-4.0) HA/AUM

.01(.01-0.1) AUM/AC 


\section{SACMB6. Willow/Forb \\ (Salix spp./Trollius albiflorus, Erigeron peregrinus, Mountain heliotrope)}

$\mathbf{n}=\mathbf{6}$ This community type results from the invasion of willow onto the forb dominated meadows (SACMA2) previously described. These meadows occupy mesic to subhygric, gently sloping, upper subalpine to alpine areas. The soils are imperfectly to well drained Gleysols on fluvial and morainal landforms (Corns and Achuff 1982). On the poorly to imperfectly drained sites in areas where snow melts late and seepage is received throughout the growing season mountain marigold and globeflower predominate. In contrast on better drained, drier sites wandering daisy and mountain heliotrope predominate.

\section{Plant COMPOSITION CANOPY COVER(\%)} mean Range Const.

SHRUBS

BARRET'S WILLOW .

(Salix barrattiana)

SMOOTH WILLOW

(Salix glauca)

BOG BIRCH

(Betula glandulosa)

$$
40
$$

$10-75 \quad 100$

$17 \quad 0-40 \quad 67$

$2 \quad 0-5 \quad 33$

FORBS

GLOBEFLOWER

(Trollius albiflorus)

WANDERING DAISY

(Erigeron peregrinus)

MOUNTAIN SAGE

(Artemisia norvegica) 6

MOUNTAIN HELIOTROPE

(Valeriana sitchensis) 4

SMOOTH LEAVED CINQUEFOIL

(Potentilla diversifolia) 4

MOUNTAIN MARIGOLD

(Caltha leptosepala)

8

4

6

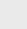

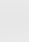

4

\section{$2-15$} 100

$0-10 \quad 83$

0-15 50

$0-15 \quad 50$

$0-10 \quad 50$
GRASSES

ALPINE TIMOTHY

(Phleum commutatum)

SEDGE

(Carex spp.)

SIMPLE BOG SEDGE

(Kobresia simpliciuscula) 13

\section{ENVIRONMENTAL VARIABLES}

MOISTURE REGIME:

MESIC

NUTRIENT REGIME:

PERMESOTROPHIC

ELEVATION:

2103(1960-2320) M

SOIL DRAINAGE:

IMPERFECTLY

ECOLOGICAL STATUS SCORE: 24

Forage Production Kg/HA

ECOLOGICALLY SUSTAINABLE STOCKING RATE GENERALLY NON-USE 40.0(40.0-1.1) HA/AUM $.01(.01-.36) \mathrm{AUM} / \mathrm{AC}$ 


\section{SACMB7. Grouseberry-Juniper \\ (Vaccinium scoparium-Juniperus communis)}

$\mathbf{n}=4$ This is a timberline community type found in conjunction with small patches of subalpine fir. Ogilvie (1969) described a heath-grouseberry community occurring among tree islands and krummholz colonies, on lee slopes with very deep snow accumulation.

\section{Plant Composition CANopy Cover(\%)} Mean Range Const.

TREES

SUBALPINE FIR

(Abies lasiocarpa)

$1 \quad 0-4$

25

SHRUBS

SMOOTH WILLOW

(Salix glauca)

GROUSEBERRY

(Vaccinium scoparium) $\quad 14 \quad 7-20 \quad 100$

GROUND JUNIPER

(Juniperus communis) $\quad 5 \quad 0-12 \quad 100$

CROWBERRY

(Emptrum nigrum)

$\begin{array}{lll}2 & 0-8 & 25\end{array}$

\section{FORBS}

FIREWEED

(Epilobium angustifolium) 12

SMALL LEAVED EVERLASTING

$\begin{array}{llll}\text { (Antennaria parviflora) } & 3 & 1-8 & 100\end{array}$

STRAWBERRY

$\begin{array}{llll}\text { (Fragaria virginiana) } & 3 & 1-5 & 100\end{array}$

YARROW

$\begin{array}{llll}\text { (Achillea millefolium) } \quad 2 & 0-2 & 100\end{array}$

GRASSES

SPIKED TRISETUM

$\begin{array}{llll}\text { (Trisetum spicatum) } & 7 & 1-20 & 100\end{array}$

SEDGE

(Carex spp.)
CALIFORNIA OATGRASS

(Danthonia californica) 6

$5-20 \quad 100$

100

\section{ENVIRONMENTAL VARIABLES}

MOISTURE REGIME:

SUBXERIC-MESIC

NUTRIENT REGIME:

MESOTROPHIC

ELEVATION:

2157(2080-2260) M

SOIL DRAINAGE:

WELL

ECOLOGICAL STATUS SCORE: 24

Forage Production Kg/HA

ECOLOGICALLY SUSTAINABLE STOCKING RATE GENERALLY NON-USE 40.0(40.0-4.5)HA/AUM .01(.01-.09) AUM/AC 


\section{SACMB8. Subalpine fir \\ (Abies lasiocarpa)}

$\mathbf{n}=\mathbf{2 2}$ This is a timberline community type found in conjunction with small patches of the grouseberry-juniper community type. The trees tend to be very small and shrub like. Ogilvie (1969) described timberline as a gradual breaking -up of the forest into groves, tree islands, low stunted krummholz colonies, and finally dwarfed isolated trees. Ogilvie found timberline to occur high on lee slopes and low on wind-exposed slopes, south facing slopes, avalanche slopes, along stream bottoms and on unstable substrata such as scree and rubble. The major environmental factors controlling timberline are low temperature, wind dessication, avalanching and snow depth.

PLANT COMPOSITION CANOPY COVER(\%) Mean Range Const.

\section{TREES}

SUBALPINE FIR

(Abies lasiocarpa)

29

$0-20$

39

\section{SHRUBS}

SMOоTH WILLOW

(Salix glauca)

GROUSEBERRY

(Vaccinium scoparium) $4 \quad 0-15 \quad 22$

WHITE FLOWERED RHODODENDRON

(Rhododendron albiflorum) $4 \quad 0-30 \quad 22$

GROUND JUNIPER

(Juniperus communis)

2

$0-15$

\section{FORBS}

\section{FIREWEED}

(Epilobium angustifolium)2

MOUNTAIN SAGE

(Artemisia norvegica) $\quad 3 \quad 0-10 \quad 61$

STRAWBERRY

$\begin{array}{llll}\text { (Fragaria virginiana) } & 1 & 0-5 & 48\end{array}$

WANDERING DAISY

(Erigeron peregrinus)

$2 \quad 0-13$

52

GRASSES

SPIKED TRISETUM

(Trisetum spicatum)

SEDGE

(Carex spp.)

HAIRY WILDRYE

(Elymus innovatus)

$\begin{array}{lll}\mathrm{T} & 0-5 & 22\end{array}$

$2 \quad 0-20 \quad 63$

$2 \quad 0-20 \quad 30$

\section{ENVIRONMENTAL VARIABLES}

MOISTURE REGIME:

MESIC

NUTRIENT REGIME:

MESOTROPHIC

ELEVATION:

1945(1610-2340) M

SOIL DRAINAGE:

WELL

ECOLOGICAL STATUS SCORE: 24

Forage Production Kg/HA

ECOLOGICALLY SUSTAINABLE STOCKING RATE GENERALLY NON-USE 40.0(40.0-5.0) HA/AUM $.01(.01-.08) \mathrm{AUM} / \mathrm{AC}$ 


\section{SUBALPINE SUBREGION}

SOUTHERN ROCKY MOUNTAINS

\section{NATIVE GRASSLANDS AND SHRUBLANDS}

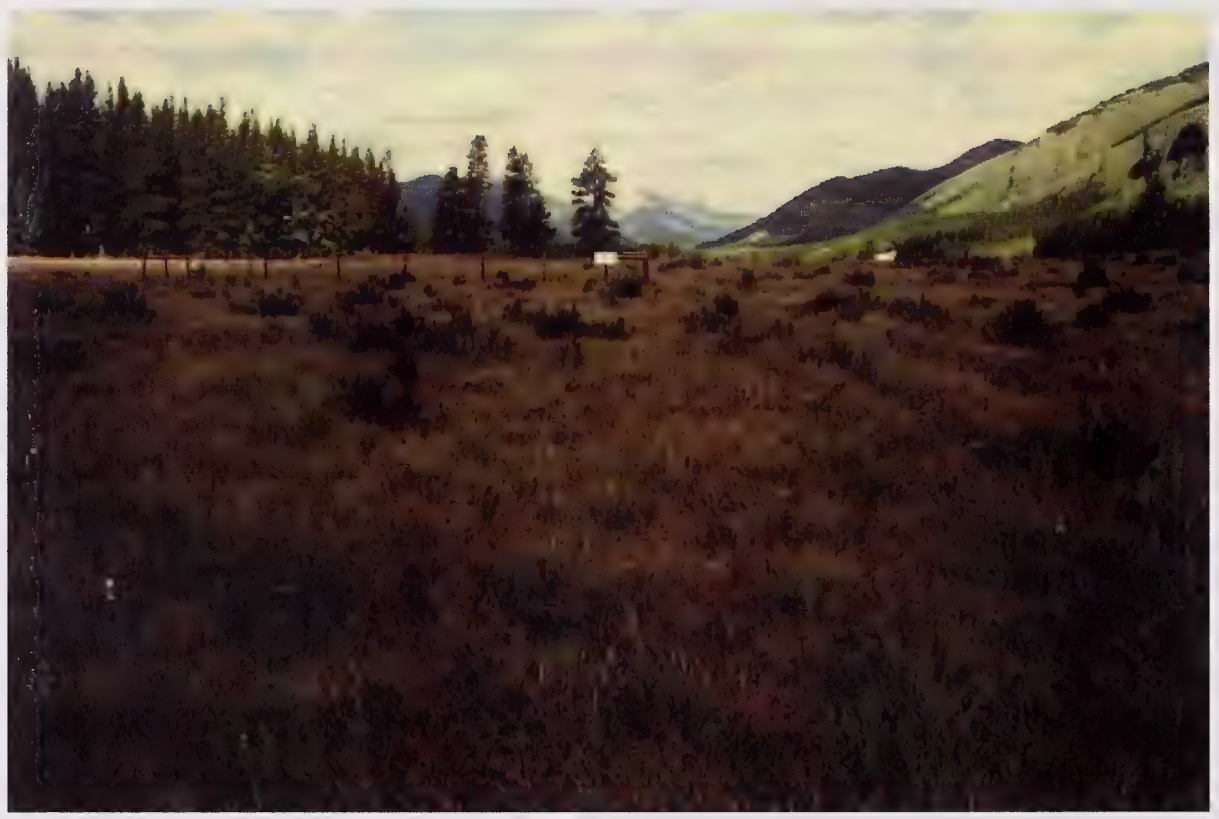

Figure 6. This figure is typical of Rough fescue-Sedge community on mesic sites in the Southern Rocky Mountains of the Subalpine subregion. On steeper slopes rough fescue and hairy wildrye predominate. 


\section{Native grass and shrubland ecology of the Southern Rocky Mountains}

The ecosites and ecosite phases of the native grass and shrubland community types in the Southern Rocky Mountains of the Subalpine subregion (Table 4) are found in the valley bottoms adjacent to streams and rivers and on south facing slopes. This also includes an area that was classified as Montane, west of Turner Valley. The grass and shrublands within this area more closely resemble the subalpine than the Montane.

The grassland and shrubland community types in this ecodistrict are strongly influenced by the lower Montane subregion. Many of the grass species associated with the Montane (rough fescue, Parry oatgrass, Idaho fescue) are associated with the grassland community types described in this ecodistrict. On the wet, imperfectly drained lower slope positions the grass and shrubland communities are very similar to the water sedge and willow/water sedge communities described in the northern ecodistricts. It is the grasslands of the south facing slopes that are different between the southern and northern ecodistricts. In the northern ecodistricts the grasslands of south facing slopes are dominated by hairy wildrye, junegrass and shrubby cinquefoil. In contrast, the grasslands of the southern ecodistrict are dominated by rough fescue, bearberry, hairy wildrye and sedge species.

On gentler south-facing slopes at lower elevations rough fescue and sedge dominate the grassland community types. On more mesic sites within this community Richardson needlegrass may become co-dominant with rough fescue. In contrast at higher elevations on steeper slopes hairy wildrye replaces sedge and Richardson needlegrass as the co-dominant species.

At higher elevations just north of Waterton Lakes National Park the windswept ridges are dominated by Idaho fescue-Junegrass, Bearberry and White mountain avens to form the FescueJunegrass/Bearberry and White mountain avens community types. These community types are important wintering areas for bighorn sheep.

Many of these subalpine grass and shrublands are very fragile because of exposure and cold climate. The forage productivity is generally only half of what is found in the lower Montane subregion and recovery from overgrazing will likely take some time because of the poor growing conditions. Grazing pressure causes rough fescue to decline and allows sedge and hairy wildrye to dominate the community. On moist sites heavy grazing pressure allows Kentucky bluegrass to invade.

The carrying capacity, moisture and nutrient regime of the grass and shrubland communities found in the Southern Rocky Mountains of the Subalpine subregion are outlined in Table 5 . 
Table 4. Ecological site, ecological site phases and community types for the Subalpine subregion in Southwestern Alberta (adapted from Archibald et al. 1996)(reference range plant communities are described in this guide, forested plant communities are outlined in guide to Ecosites of Southwestern Alberta)

\begin{tabular}{|c|c|c|c|c|c|}
\hline & Ecological Site & $\begin{array}{l}\text { Ecological Site } \\
\text { Phase }\end{array}$ & Forested Plant Community Type & $\begin{array}{c}\text { Reference Range Plant } \\
\text { Community Type }\end{array}$ & $\begin{array}{c}\text { Successional Community } \\
\text { Types }\end{array}$ \\
\hline \multirow[t]{2}{*}{ a } & \multirow{2}{*}{$\begin{array}{l}\text { lichen } \\
\text { (xeric/poor) }\end{array}$} & a1 lichen P1 & a1.1 P1/juniper/lichen & SASME1 P1/Juniper & \\
\hline & & a2 grassland & & $\begin{array}{l}\text { SASMA13 Fescue-Junegrass/ Early } \\
\text { yellow locoweed } \\
\text { SASMA14 White Mtn. avens } \\
\text { SASMA17 Bluebunch wheatgrass- } \\
\text { Sedge }\end{array}$ & \\
\hline \multirow[t]{3}{*}{ b } & \multirow{3}{*}{$\begin{array}{l}\text { bearberry/hairy wild } \\
\text { rye } \\
\text { (submesic/medium) }\end{array}$} & $\begin{array}{l}\text { b1 bearberry/hairy wild } \\
\text { rye } \mathrm{P} 1\end{array}$ & b1.1 P1/bearberry/hairy wild rye & & \\
\hline & & b2 grassland & & $\begin{array}{l}\text { SASMA2 Rough fescue-Sedge } \\
\text { SASMA3 Rough fescue-Hairy } \\
\text { wildrye-Sedge } \\
\text { SASMA6 Yellow mtn. Avens } \\
\text { SASMA9 Rough fescue- } \\
\text { Sedge/Bearberry } \\
\text { SASMA10 Parry oatgrass-Rough } \\
\text { fescue-Sedge } \\
\text { SASMA3a Hairy wildrye-R.fescue- } \\
\text { Sedge }\end{array}$ & $\begin{array}{l}\text { SASMA4 Sedge-Hairy } \\
\text { wildrye-Slender wheatgrass } \\
\text { SASMA11 Sedge/Bearberry } \\
\text { SASMC2 Parry oatgrass- } \\
\text { Kentucky bluegrass-Sedge } \\
\text { SASMC4 Fringed } \\
\text { sage/Kentucky bluegrass-Parry } \\
\text { oatgrass } \\
\text { SASMC9 Idaho fescue-Rough } \\
\text { fescue/Bearberry } \\
\text { SASMC11Idaho fescue-Sheep } \\
\text { fescue-bluegrass }\end{array}$ \\
\hline & & b3 shrubland & & $\begin{array}{l}\text { SASMB2 Willow/Richardson } \\
\text { needlegrass } \\
\text { SASMB7 Smooth willow-Juniper/ } \\
\text { Hairy wildrye }\end{array}$ & \\
\hline
\end{tabular}




\begin{tabular}{|c|c|c|c|c|c|}
\hline & b4 bearberry-Aw & & & SASMD10 Aw/Bearberry-Juniper & \\
\hline \multirow{2}{*}{$\begin{array}{l}\text { subalpine } \\
\text { larch/heather } \\
\text { (submesic/poor) }\end{array}$} & $\begin{array}{l}\text { c1 subalpine larch/heather } \\
\text { La-Fa }\end{array}$ & $\mathrm{cl} .1$ & $\mathrm{La}-\mathrm{Fa} /$ heather-grouse-berry & & \\
\hline & c2 yellow mountain avens & & & SASMA6 Yellow mountain avens & \\
\hline \multirow[t]{3}{*}{$\begin{array}{l}\text { cc rough fescue } \\
\text { (mesic/rich) }\end{array}$} & cc1 rough fescue & & & $\begin{array}{l}\text { SASMA8 Rough fescue-Idaho } \\
\text { fescue-Parry oatgrass } \\
\text { SASMA2a Rough fescue-Richardson } \\
\text { needlegrass }\end{array}$ & $\begin{array}{l}\text { SASMA5 Kentucky } \\
\text { bluegrass/Dandelion } \\
\text { SASMC1 Parry oatgrass- } \\
\text { Rough fescue-Kentucky } \\
\text { bluegrass } \\
\text { SASMC3 Meadow foxtail- } \\
\text { Kentucky bluegrass } \\
\text { SASMC5 Rough fescue- } \\
\text { Kentucky bluegrass } \\
\text { SASMC6 Kentucky bluegrass- } \\
\text { Rough fescue } \\
\text { SASMC7 Timothy-Slender } \\
\text { wheatgrass/Fireweed }\end{array}$ \\
\hline & cc2 shrubland & & & $\begin{array}{l}\text { SASMA12 Silverberry-Rose } \\
\text { SASMB6 Smooth willow-Shrubby } \\
\text { cinquefoil/Hairy wildrye }\end{array}$ & \\
\hline & cc3 forb meadow & & & SASMA16 Forb meadow & \\
\hline $\begin{array}{ll}\text { d } & \begin{array}{l}\text { spruce/heather } \\
\text { (mesic/poor) }\end{array} \\
\end{array}$ & d1 spruce/heather Se & $\mathrm{d} 1.1$ & Se/heather & & \\
\hline \multirow{3}{*}{$\begin{array}{l}\text { e false azalea-grouse- } \\
\text { berry } \\
\text { (mesic/medium) }\end{array}$} & \multirow[t]{3}{*}{$\begin{array}{l}\text { el false azalea-grouse- } \\
\text { berry P1 }\end{array}$} & $\mathrm{e} 1.1$ & $\mathrm{P} 1$ /green alder/arnica & & \\
\hline & & $\mathrm{e} 1.2$ & $\begin{array}{l}\text { P1/grouse-berry/feather } \\
\text { moss }\end{array}$ & & \\
\hline & & e1.3 & P1/low bilberry & & \\
\hline
\end{tabular}




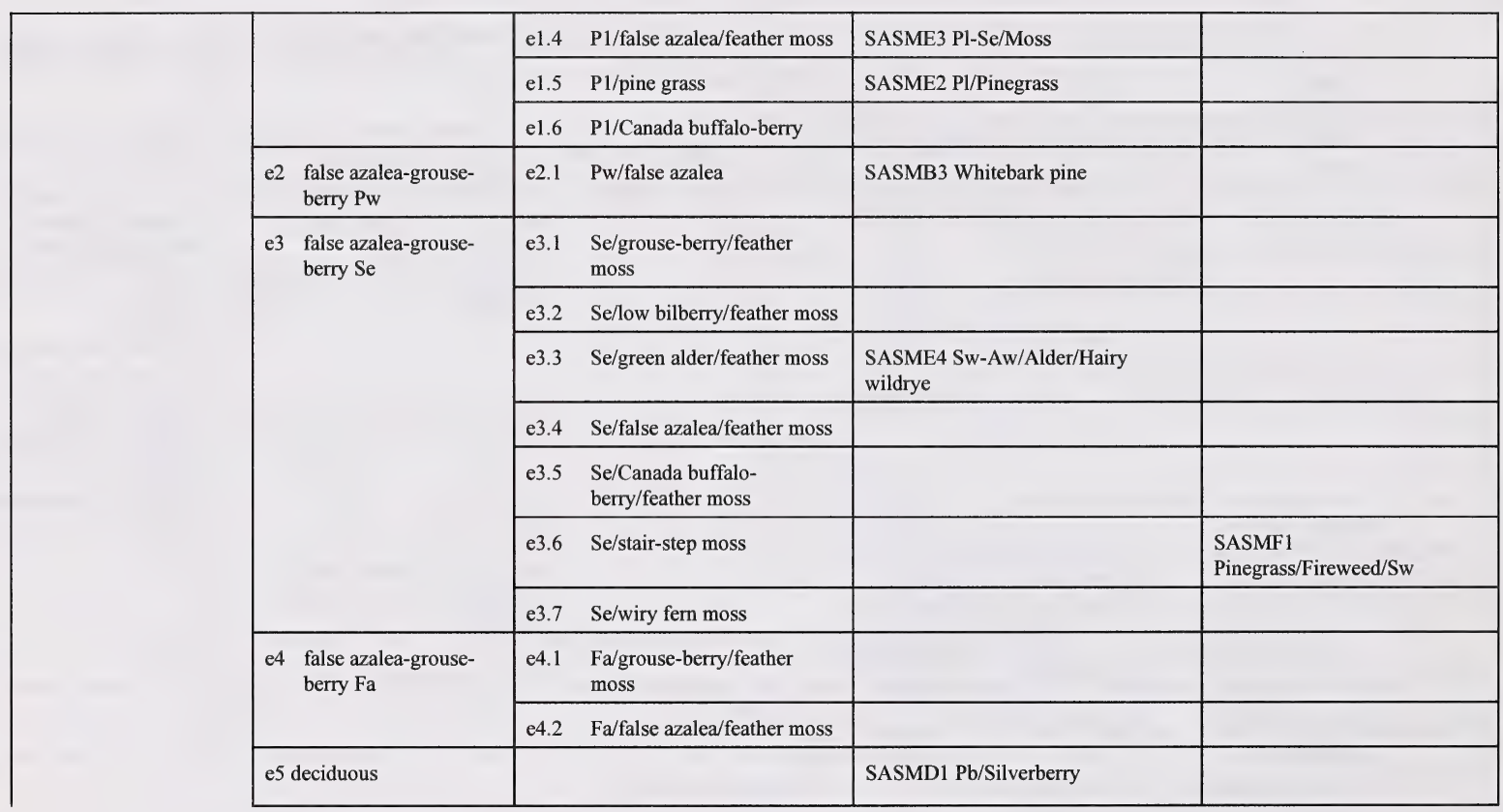




\begin{tabular}{|c|c|c|c|c|c|}
\hline & \multirow[b]{2}{*}{ e6 grassland } & & $\begin{array}{l}\text { SASMD2 Aw/Rose/Pinegrass } \\
\text { SASMD9 Aw/Rose/Marsh reedgrass }\end{array}$ & $\begin{array}{l}\text { SASMD3 Aw/Fireweed/ } \\
\text { Meadow foxtail } \\
\text { SASMD4 Aw/Rose/ } \\
\text { Canada bluegrass } \\
\text { SASMD8 Aw/K. } \\
\text { bluegrass/Clover }\end{array}$ \\
\hline & & & & $\begin{array}{l}\text { SASMA15 Pinegrass-Hairy } \\
\text { wildrye/Strawberry }\end{array}$ & $\begin{array}{l}\text { SASMC11Creeping red } \\
\text { fescue/Clover } \\
\text { SASMC12 Rose/Pinegrass }\end{array}$ \\
\hline & & e7 shrubland & & SASMB9 Bebb willow/Pinegrass & \\
\hline \multirow{4}{*}{\multicolumn{2}{|c|}{$\begin{array}{l}\text { f thimbleberry } \\
\text { (subhygric/rich) }\end{array}$}} & f1 thimbleberry P1 & f1.1 P1/thimbleberry & & \\
\hline & & f2 thimbleberry Fa-Se & f2.1 Fa-Se/Thimbleberry & & \\
\hline & & $\mathrm{f} 3$ thimbleberry $\mathrm{Aw}-\mathrm{Pb}$ & & $\begin{array}{l}\text { SASMD5 } \mathrm{Aw}-\mathrm{Pb} / \mathrm{Cow} \text { parsnip } \\
\mathrm{SASMD} 7 \mathrm{~Pb} / \mathrm{Willow} / \mathrm{Marsh} \\
\text { reedgrass }\end{array}$ & $\begin{array}{l}\text { SASMD6 Aw-Pb/Cow } \\
\text { parsnip/Timothy }\end{array}$ \\
\hline & & f4 shrubby seepages & & $\begin{array}{l}\text { SASMA7a Marsh reedgrass/Cow } \\
\text { parsnip }\end{array}$ & $\begin{array}{l}\text { SASMC8 Marsh reedgrass- } \\
\text { Timothy/Cow parsnip }\end{array}$ \\
\hline & $\begin{array}{l}\text { dwarf birch/tufted } \\
\text { hair grass } \\
\text { (hygric/rich) }\end{array}$ & $\begin{array}{l}\text { g1 dwarf birch/tufted hair } \\
\text { grass }\end{array}$ & g1.1 dwarf birch/tufted hair grass & $\begin{array}{l}\text { SASMA7 Tufted hairgrass-Sedge } \\
\text { SASMAla Beaked sedge-Alpine } \\
\text { foxtail-Tufted hairgrass }\end{array}$ & $\begin{array}{l}\text { SASMB4 Willow-Bog birch/R. } \\
\text { fescue- Kentucky bluegrass } \\
\text { SASMA5 Kentucky } \\
\text { bluegrass/Dandelion } \\
\text { SASMB8 Willow/Tufted } \\
\text { hairgrass-K. bluegrass } \\
\text { SASMC10 Tufted hairgrass-K. } \\
\text { bluegrass }\end{array}$ \\
\hline \multirow{2}{*}{\multicolumn{2}{|c|}{$\begin{array}{ll}\text { h } & \text { horsetail } \\
\text { (subhydric/rich) }\end{array}$}} & h1 horsetail Se & h1.1 Se/horsetail/feather moss & & \\
\hline & & h2 horsetail fen & $\begin{array}{l}\text { h2.1 dwarf birch/sedge/golden } \\
\text { moss }\end{array}$ & & \\
\hline
\end{tabular}




\begin{tabular}{|l|l|l|l|l|}
\hline \multirow{2}{*}{$\begin{array}{l}\text { i fen } \\
\text { (subhydric/rich) }\end{array}$} & i1 shrub fen & & $\begin{array}{l}\text { SASMB1 Willow/Sedge } \\
\text { SASMB5 Willow/Marsh reedgrass }\end{array}$ & \\
\cline { 2 - 5 } & i2 graminoid fen & & SASMA1 Water sedge & \\
\cline { 2 - 5 } & i3 treed fen & SASME5 Sw/Willow-Labrador tea & \\
\hline
\end{tabular}


Edatopic grid for the ecological sites in the Southern ecodistricts of the Subalpine

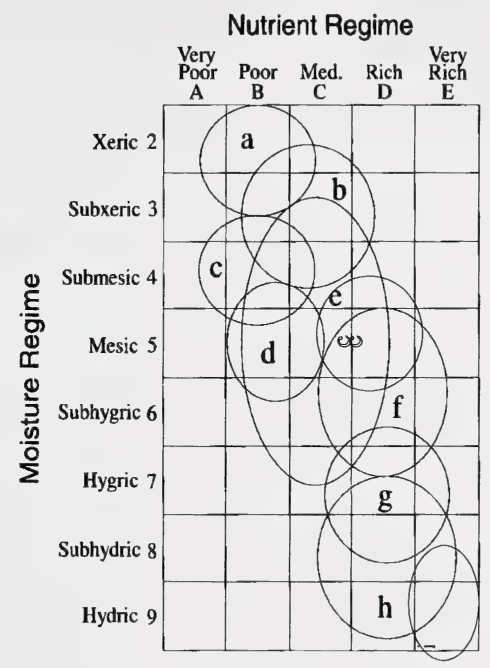

\section{Ecological Sites}

\section{a lichen}

(xeric/poor)

b bearberry/hairy wildrye

(submesic/medium)

c subalpine larch/heather

(submesic/poor)

cc rough fescue

(mesic/rich)

d spruce/heather

(mesic/poor)

e false azalea-grouseberry

(mesic/medium)

f thimbleberry

(subhygric/rich)

g dwarf birch tufted hairgrass

(hygric/rich)

$h$ horsetail

(subhydric/rich)

i fen

(hydric/rich) 


\section{a2 grassland $(\mathrm{n}=30)$}

\section{CHARACTERISTIC SPECIES}

\section{Shrubs}

[2] Shrubby cinquefoil

\section{Forbs}

[ 15] White mtn. avens

[1] Bearberry

[1] False dandelion

[2] Spotted saxifrage

[1] Sandwort

[1] Kittentail

[2] Early yellow locoweed

\section{Graminoids}

[3] Sedge

[1] Junegrass

[3] Idaho fescue

[1] Rough fescue

\section{COMMUNITY TYPES}

SASMA13 Fescue-Junegrass/Early yellow locoweed(n=17) SASMA14 White mtn. avens $(\mathrm{n}=12)$ SASMA17 Bluebunch wheatgrass-Sedge $(n=1)$

\section{SITE CHARACTERISTICS}

Moisture regime: subxeric, submesic

Nutrient regime: poor, very poor

Topographic position: upper slope, crest

Slope: (6-40)

Aspect: variable

\section{SOIL CHARACTERISTICS}

Organic thickness: $(0-2)$

Humus form: not available

Surface texture: SL,S,L

Effective texture: SL,LS

Depth to Mottles/Gley: none

Drainage: rapid, well

Parent material: $\mathrm{M}, \mathrm{C} / \mathrm{X}$

Soil subgroup:, O.R, non-soil 
b2 grassland $(n=56)$

\section{CHARACTERISTIC SPECIES}

\section{Shrubs}

[8] Shrubby cinquefoil

Forbs

[4] Yellow beardtongue

[17] Bearberry

[2] Yellow hedysarum

[2] Brown bracted everlasting

[2] Yarrow

[1] Kittentail

[2] Strawberry

\section{Graminoids}

[9] Sedge

[1] Junegrass

[2] Idaho fescue

[20] Rough fescue

[9] Parry oatgrass

[2] Richardson needlegrass

\section{COMMUNITY TYPES}

SASMA2 Rough fescue-Sedge $(\mathrm{n}=18)$

SASMA3 Rough fescue-Hairy wildrye-Sedge $(n=10)$

SASMA3a Hairy wildrye-Rough fescue-Sedge $(n=1)$

SASMA6 Yellow mtn. Avens $(\mathrm{n}=1)$

SASMA9 Rough fescue-Sedge/Bearberry( $\mathrm{n}=14)$

SASMA10 Parry oatgrass-Rough fescue-

Sedge $(n=12)$

\section{SITE CHARACTERISTICS}

Moisture regime: subxeric, submesic, mesic

Nutrient regime: medium

Topographic position: upper slope, crest

Slope: (0-50)

Aspect: south, west

\section{SOIL CHARACTERISTICS}

Organic thickness: $(0-2)(2-10)$

Humus form: mull

Surface texture: SL, LS

Effective texture: SL, LS

Depth to Mottles/Gley: none

Drainage: rapid, well

Parent material: M,C, GF

Soil subgroup:, O.R, O.EB, O.MB 


\section{CHARACTERISTIC SPECIES}

\section{Shrubs}

[4] Shrubby cinquefoil

[1] Saskatoon

[1] Juniper

Forbs

[6] Old man's whiskers

[8] Bearberry

[2] Yellow hedysarum

[1] Brown bracted everlasting

[4] Yarrow

[1] Sandwort

[2] Strawberry

\section{Graminoids}

$\begin{array}{ll}\text { [9] } & \text { Sedge } \\ {[1]} & \text { Junegrass } \\ {[2]} & \text { Idaho fescue } \\ {[5]} & \text { Rough fescue } \\ \text { [4] } & \text { Parry oatgrass } \\ {[3]} & \text { Kentucky bluegrass } \\ {[1]} & \text { Timothy }\end{array}$

\section{SITE CHARACTERISTICS}

Moisture regime: subxeric, submesic, mesic

Nutrient regime: medium

Topographic position: upper slope, crest

Slope: $(0-50)$

Aspect: south, west

\section{SOIL CHARACTERISTICS}

Organic thickness: $(0-2)(2-10)$

Humus form: mull

Surface texture: SL, LS

Effective texture: SL,LS

Depth to Mottles/Gley: none

Drainage: rapid, well

Parent material: $\mathrm{M}, \mathrm{C}, \mathrm{GF}$

Soil subgroup:, O.R, O.EB, O.MB

\section{COMMUNITY TYPES}

SASMA4 Sedge-Hairy wildrye-Slender

wheatgrass $(\mathrm{n}=15)$

SASMA11 Sedge/Bearberry $(\mathrm{n}=11)$

SASMC2 Parry oatgrass-Kentucky bluegrass-

Sedge $(\mathrm{n}=4)$

SASMC4 Fringed sage/Kentucky bluegrass-Parry oatgrass $(\mathrm{n}=1)$

SASMC9 Idaho fescue-Rough fescue/Bearberry $(\mathrm{n}=2)$

SASMC13 Idaho fescue-Sheep fescue-bluegrass $(\mathrm{n}=1)$ 
b3 shrubland $(n=4)$

\section{CHARACTERISTIC SPECIES}

\section{Shrubs}

[30] Willow

[5] Bog birch

[5] Shrubby cinquefoil

\section{Forbs}

[1] Northern valerian

[1] Yarrow

[1] Fireweed

[2] Strawberry

\section{Graminoids}

[3] Sedge

[ 8] Rocky mtn. fescue

[45] Richardson needlegrass

[1] Slender wheatgrass

\section{COMMUNITY TYPES}

SASMB2 Willow/Richardson needlegrass $(n=2)$

SASMB7 Smooth willow-Juniper/Hairy

wildrye $(n=2)$

\section{SITE CHARACTERISTICS}

Moisture regime: submesic, mesic

Nutrient regime: medium

Topographic position: lower slope

Slope: $(0-5)$

Aspect: south, west

\section{SOIL CHARACTERISTICS}

Organic thickness: $(0-2)(2-10)$

Humus form: mull

Surface texture: SL, LS

Effective texture: SL,LS

Depth to Mottles/Gley: none

Drainage: well

Parent material: F, GF, C

Soil subgroup:, O.R, O.EB 
b4 hearberry - $\Delta \mathrm{w}(\mathrm{n}=1$

\section{CHARACTERISTIC SPECIES}

Trees

[8] Aspen

[5] Lodgepole pine

\section{Shrubs}

[8] Buffaloberry

[5] Juniper

\section{Forbs}

[40] Bearberry

[1] Yellow hedysarum

[5] Small leaved everlasting

[6] Early yellow locoweed

\section{Graminoids}
[5] Sedge
[2] Rocky mtn. fescue
[7] Junegrass
[6] Slender wheatgrass

\section{SITE CHARACTERISTICS}

Moisture regime: submesic, mesic

Nutrient regime: medium

Topographic position: lower slope

Slope: (0-5)

Aspect: south, west

\section{SOIL CHARACTERISTICS}

Organic thickness: $(0-2)(2-10)$

Humus form: mull

Surface texture: SL, LS

Effective texture: SL,LS

Depth to Mottles/Gley: none

Drainage: well

Parent material: F, GF, C
Soil subgroup:, O.R, O.EB

\section{COMMUNITY TYPES}

SASMD10 Aw/Bearberry-Juniper(n=1) 
c2 yellow mtn. avens $(n=1)$

\section{CHARACTERISTIC SPECIES}

Shrubs

[4] Shrubby cinquefoil

\section{Forbs}

[13] Yellow mtn. avens

[5] Late yellow locoweed

[3] Silvery cinquefoil

[3] Low goldenrod

[3] Yellow hedysarum

Graminoids

[67] Sedge

[6] Hairy wildrye

[5] Fringed brome

[1] Slender wheatgrass

\section{SITE CHARACTERISTICS}

Moisture regime: subxeric, submesic

Nutrient regime: poor, medium

Topographic position: floodplain

Slope: (0-5)

Aspect: variable

\section{SOIL CHARACTERISTICS}

Organic thickness: $(0-2)$

Humus form: mor

Surface texture: SL,SiL

Effective texture: SL,

Depth to Mottles/Gley: none

Drainage: rapid, well

Parent material: F,GF

Soil subgroup:, O.R

\section{COMMUNITY TYPES}

SASMA6 Yellow mtn. avens $(\mathrm{n}=1)$ 


\section{GENERAL DESCRIPTION}

This ecosite is typical of south and west facing slopes and lower slope positions throughout the southern mountains of the Subalpine subregion from an elevation of $1500 \mathrm{~m}$ to $1900 \mathrm{~m}$. This ecosite is usually dominated by grass species because of the dry site conditions and westerly winds. The soils of this ecosite are dominated by deep black soils. A number of rough fescue dominated sites have not had the species composition change in over 30 years of no disturbance in the Montane subregion indicating the climax nature of this ecosite.

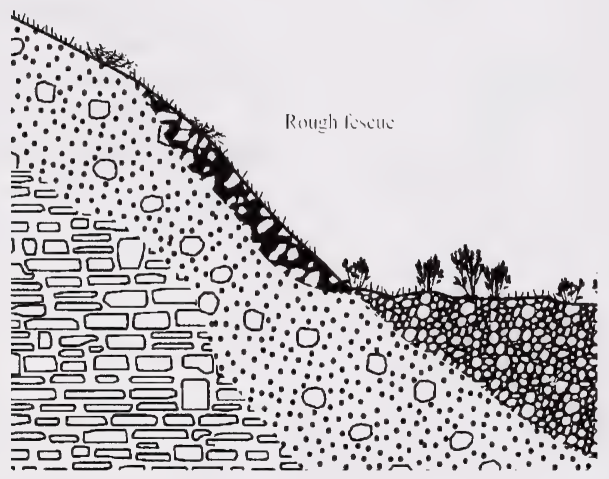

\section{SUCCESSIONAL RELATIONSHIPS}

Due to the nature of the site grasslands often remain the climax vegetation on these sites. On moister sites shrubs and trees such as saskatoon, snowberry, chokecherry and aspen often invade the site. Heavy grazing pressure on these grasslands can often lead to a degraded site that is dominated by Kentucky bluegrass, timothy and clover species.

\section{INDICATOR SPECIES}

rough fescue

Parry oatgrass

Idaho fescue

Old man's whiskers

Silverberry
Kentucky bluegrass

Timothy

Dandelion

Cut leaved anemone

Rose mesic/rich

\section{SITE CHARACTERISTICS}

Moisture regime: submesic, mesic

Nutrient regime: rich, medium

Topographic position: crest, midslope, lower slope Slope: $(0-2 \%)^{5}(16-30 \%)^{3}(31-45 \%)^{1}(45-70 \%)^{1}$

Aspect: south, southwest, west

\section{SOIL CHARACTERISTICS}

Organic thickness: $(0-2)(2-5)$

Humus form: mull

Surface texture: CL,SiL, L

Effective texture: CL, SiL, SL,

Depth to Mottles/Gley: none

Drainage: well

Parent material: F, GF, M

Soil subgroup: O.BL, O.DG, O.MB

\section{ECOSITE PHASES}

ccl rough fescue $(\mathrm{n}=10)$

ccla grazed rough fescue $(\mathrm{n}=53)$

cc2 shrubland $(\mathrm{n}=2)$ 
cc1

rough fescue $(n=10)$

\section{CHARACTERISTIC SPECIES}

\section{Shrubs}

[6] Shrubby cinquefoil

[4] Rose

[3] Saskatoon

\section{Forbs}

[15] Showy aster

[10] Strawberry

[7] Sticky purple geranium

[1] White mtn. avens

[3] Northern bedstraw

\section{Graminoids}

[23] Rough fescue

[10] Idaho fescue

[4] Parry oatgrass

[3] Sedge

\section{COMMUNITY TYPES}

SASMA8 Rough fescue-Idaho fescue-Parry oatgrass $(n=4)$

SASMA2a Rough fescue-Richardson needlegrass $(\mathrm{n}=6)$

\section{SITE CHARACTERISTICS}

Moisture regime: submesic, mesic

Nutrient regime: rich, medium

Topographic position: crest, midslope, lower slope Slope: $(0-2 \%)^{5}(16-30 \%)^{3}(31-45 \%)^{1}(45-70 \%)^{1}$

Aspect: south, southwest, west

\section{SOIL CHARACTERISTICS}

Organic thickness: $(0-2)(2-5)$

Humus form: mull

Surface texture: CL,SiL, L

Effective texture: CL, SiL, SL,

Depth to Mottles/Gley: none

Drainage: well

Parent material: F, GF, M

Soil subgroup: O.BL, O.DG, O.MB 
cc1a grazed rough fescue $(n=53)$

\section{CHARACTERISTIC SPECIES}

Shrubs

[4] Shrubby cinquefoil

[2] Rose

[1] Saskatoon

\section{Forbs}

[4] Dandelion

[1] Strawberry

[2] Old man's whiskers

[2] Yarrow

[2] Clover

[3] Graceful cinquefoil

\section{Graminoids}

[ 8] Rough fescue

[1] Idaho fescue

[2] Parry oatgrass

[1] Sedge

[15] Kentucky bluegrass

[8] Timothy

\section{SITE CHARACTERISTICS}

Moisture regime: submesic, mesic

Nutrient regime: rich, medium

Topographic position: crest, midslope, lower slope Slope: $(0-2 \%)^{5}(16-30 \%)^{3}(31-45 \%)^{1}(45-70 \%)^{1}$

Aspect: south, southwest, west

\section{SOIL CHARACTERISTICS}

Organic thickness: $(0-2)(2-5)$

Humus form: mull

Surface texture: CL,SiL, L

Effective texture: CL, SiL, SL,

Depth to Mottles/Gley: none

Drainage: well

Parent material: F, GF, M

Soil subgroup: O.BL, O.DG, O.MB

\section{COMMUNITY TYPES}

SASMA5 Kentucky bluegrass/Dandelion( $\mathrm{n}=14$ ) SASMC1 Parry oatgrass-Rough fescue-Kentucky bluegrass $(\mathrm{n}=8)$

SASMC3 Meadow foxtail-Kentucky bluegrass $(n=3)$ SASMC5 Rough fescue-Kentucky bluegrass $(\mathrm{n}=3)$ SASMC6 Kentucky bluegrass-Rough fescue $(\mathrm{n}=17)$ SASMC7 Timothy-Slender wheatgrass/Fireweed(n=8) 
cc2 shrubland $(n=2)$

\section{CHARACTERISTIC SPECIES}

Trees

[8] Aspen

Shrubs

[15] Silverberry

[5] Rose

Forbs

[6] Chickweed

[2] False dandelion

[1] Silver plant

\section{Graminoids}

[1] Rocky mtn. fescue

[9] Bluebunch wheatgrass
SASMA15 Silverberry-Rose $(\mathrm{n}=1)$

SASMB6 Smooth willow-Shrubby cinquefoil/Hairy wildrye $(\mathrm{n}=1)$

\section{SITE CHARACTERISTICS}

\section{Moisture regime: mesic}

Nutrient regime: rich

Topographic position: crest, midslope

Slope: $(16-30 \%)$

Aspect: south

\section{SOIL CHARACTERISTICS}

Organic thickness: $(0-2)(2-5)$

Humus form: mull

Surface texture: CL,SiL, L

Effective texture: $\mathrm{CL}, \mathrm{SiL}, \mathrm{SL}$,

Depth to Mottles/Gley: none

Drainage: well

Parent material: F, GF, M

Soil subgroup: O.BL, O.DG, O.MB 


\section{CHARACTERISTIC SPECIES}

\section{Shrubs}

[3] Shrubby cinquefoil

[2] Rose

\section{Forbs}

[3] Graceful cinquefoil

[4] Yellow hedysarum

[2] American vetch

[6] Fireweed

[1] Strawberry

\section{Graminoids}

[2] Parry oatgrass

[3] Hairy wildrye

[2] Rough fescue

\section{SITE CHARACTERISTICS}

Moisture regime: mesic, subhygric

Nutrient regime: rich, medium

Topographic position: lower slope

Slope: (0-8\%)

Aspect: south, level

\section{SOIL CHARACTERISTICS}

\section{Organic thickness: (6-15)}

Humus form: moder

Surface texture: SL,SiL, L,C

Effective texture: CL, SiL, SCL,

Depth to Mottles/Gley: none, (0-25)

Drainage: well, mod. well

Parent material: F, C, M, X

Soil subgroup: O.EB, E.DYB, O.EB, BR.GL 


\section{CHARACTERISTIC SPECIES}

SASMD1 $\mathrm{Pb} /$ Silver berry $(\mathrm{n}=1)$

Trees

[20] Aspen

[10] Balsam poplar

Shrubs

[2] Silverberry

[7] Rose

[3] White meadowsweet

Forbs

[5] American vetch

[6] Yellow peavine

[4] Strawberry

[4] Fireweed

[4] Showy aster

[1] Alpine hedysarum

Graminoids

[14] Pinegrass

[6] Hairy wildrye

[1] Junegrass

\section{SITE CHARACTERISTICS}

Moisture regime: mesic

Nutrient regime: medium

Topographic position: midslope, lower slope,

floodplain

Slope: $(0-5 \%)$

Aspect: south, level

\section{SOIL CHARACTERISTICS}

Organic thickness: $(0-2)(2-5)$

Humus form: mor

Surface texture: SL,SiL, L

Effective texture: CL, SiL, SCL,

Depth to Mottles/Gley: none

Drainage: well, mod. well

Parent material: F, C, M

Soil subgroup: O.EB, E.DYB, O.EB, BR.GL 
e5a grazed deciduous $(n=2)$

\section{CHARACTERISTIC SPECIES}

\section{Trees}

[35] Aspen

[3] White spruce

Shrubs

[5] Gooseberry

[6] Rose

Forbs

[1] American vetch

[3] Yellow peavine

[3] Strawberry

[6] Fireweed

[13 ] Lindley aster

[2] Dandelion

Graminoids

[4] Pinegrass

[2] Kentucky bluegrass

[ 18 ] Canada bluegrass

[16] Meadow foxtail

[9] Orchardgrass

[3] Timothy

\section{SITE CHARACTERISTICS}

Moisture regime: mesic

Nutrient regime: medium

Topographic position: midslope, lower slope

Slope: $(0-5 \%)$

Aspect: south, level

\section{SOIL CHARACTERISTICS}

Organic thickness: $(0-2)(2-5)$

Humus form: mor

Surface texture: SL,SiL, L

Effective texture: CL, SiL, SCL,

Depth to Mottles/Gley: none

Drainage: well, mod. well

Parent material: F, C, M

Soil subgroup: O.EB, E.DYB, O.EB, BR.GL

\section{COMMUNITY TYPES}

SASMD3 Aw/Fireweed/Meadow foxtail( $\mathrm{n}=1$ )

SASMD4 Aw/Rose/Canada bluegrass( $\mathrm{n}=1)$ 
e6 grassland $(n=4)$

\section{CHARACTERISTIC SPECIES}

\section{Shrubs}

[1] Shrubby cinquefoil

[9] Rose

Forbs

[4] Lupine

[2] Yellow peavine

[3] Dandelion

[1] Graceful cinquefoil

[3] Showy aster

[1] False mtn. dandelion

Graminoids

[11] Pinegrass

[2] Junegrass

[4]. Hairy wildrye

[3] Kentucky bluegrass
SASMA15 Pinegrass-Hairy wildrye/Strawberry $(n=4)$

\section{SITE CHARACTERISTICS}

Moisture regime: mesic

Nutrient regime: medium

Topographic position: crest, midslope, lower slope

Slope: (16-30\%)

Aspect: southerly

\section{SOIL CHARACTERISTICS}

Organic thickness: $(0-2)(2-5)$

Humus form: mull

Surface texture: CL,SiL, L

Effective texture: CL, SiL, SL,

Depth to Mottles/Gley: none

Drainage: well, rapid

Parent material: $\mathrm{C}, \mathrm{M}$

Soil subgroup: O.EB, O.MB, O.DG 
e7 shrubland (n=1)

\section{CHARACTERISTIC SPECIES}

\section{Trees}

[20] Lodgepole pine

[10] White spruce

\section{Shrubs}

[51] Willow

[2] Rose

[3] Bracted honeysuckle

\section{Forbs}

[15] Scouring rush

[14] Lindley's aster

[9] Fireweed

[6] Strawberry

Graminoids

[5] Pinegrass

[5] Beaked sedge

[4] Tufted hairgrass

\section{SITE CHARACTERISTICS}

Moisture regime: mesic

Nutrient regime: medium

Topographic position: lower slope

Slope: $0-5 \%$

Aspect: variable

\section{SOIL CHARACTERISTICS}

Organic thickness: $0-25$

Humus form: mull

Surface texture: CL,SiL, L

Effective texture: $\mathrm{CL}, \mathrm{SiL}, \mathrm{SL}$,

Depth to Mottles/Gley: none

Drainage: well,moderately well

Parent material: C, M

Soil subgroup: O.HG 
f3 thimbleberry $\mathrm{Aw}-\mathrm{Pb}(\mathrm{n}=4)$

\section{CHARACTERISTIC SPECIES}

Trees

[30] Aspen

[10] Balsam poplar

Shrubs

[6] Gooseberry

[1] Rose

Forbs

[48] Cow parsnip

[2] Yellow peavine

[15] Canada violet

[6] Fireweed

[22] Lindley aster

[12] Tall lungwort

[12] Tall larkspur

Graminoids

[1] Marsh reedgrass

[2] Hairy wildrye

[2] Sedge

\section{COMMUNITY TYPES}

SASMD5 Aw-Pb/Cow parsnip(n=3)

SASMD7 Aw-Pb/Willow/Marsh reedgrass $(\mathrm{n}=1)$

\section{SITE CHARACTERISTICS}

Moisture regime: subhygric

Nutrient regime: rich

Topographic position: lower slope

Slope: $(0-8 \%)$

Aspect: south, level

\section{SOIL CHARACTERISTICS}

Organic thickness: (6-15)

Humus form: moder

Surface texture: SL,SiL, L,C

Effective texture: CL, SiL, SCL,

Depth to Mottles/Gley: none, (0-25)

Drainage: well, mod. well

Parent material: F, C, M, X

Soil subgroup: O.EB, E.DYB, O.EB, BR.GL 


\section{CHARACTERISTIC SPECIES}

\section{Trees}

[26] Aspen

[ 16] Balsam poplar

Shrubs

[4] Raspberry

[1] Rose

Forbs

[2] Cow parsnip

[2] Yellow peavine

[2] Canada violet

[6] Fireweed

[19] Lindley aster

[12] White geranium

[6] Dandelion

\section{Graminoids}

[4] Marsh reedgrass

[18] Timothy

[4] Kentucky bluegrass

[7] Smooth wildrye

\section{SITE CHARACTERISTICS}

Moisture regime: subhygric

Nutrient regime: rich

Topographic position: lower slope, midslope

Slope: $(0-8 \%)$

Aspect: south, level, north

\section{SOIL CHARACTERISTICS}

\section{Organic thickness: (6-15)}

Humus form: moder

Surface texture: SL,SiL, L,C

Effective texture: CL, SiL, SCL,

Depth to Mottles/Gley: none, (0-25)

Drainage: well, mod. well

Parent material: F, C, M, X

Soil subgroup: O.EB, E.DYB, O.EB, BR.GL 


\section{CHARACTERISTIC SPECIES}

Shrubs

[1] Raspberry

[4] Rose

Forbs

[3] Cow parsnip

[10] Western meadow rue

[4] Canada violet

[25] Fireweed

[4] Horsetail

[4] Sticky purple geranium

[1] Dandelion

Graminoids

[24] Marsh reedgrass

[15] Sedge

[5] Idaho fescue

[2] Brome

\section{SITE CHARACTERISTICS}

Moisture regime: subhygric

Nutrient regime: rich

Topographic position: lower slope, midslope

Slope: $(0-8 \%)$

Aspect: south, level, north

\section{SOIL CHARACTERISTICS}

Organic thickness: (6-15)

Humus form: moder

Surface texture: SL,SiL, L,C

Effective texture: $\mathrm{CL}, \mathrm{SiL}, \mathrm{SCL}$,

Depth to Mottles/Gley: none, (0-25)

Drainage: well, mod. well

Parent material: F, C, M, X

Soil subgroup: O.EB, E.DYB, O.EB, BR.GL 


\section{CHARACTERISTIC SPECIES}

\section{Shrubs}

[6] Raspberry

Forbs

[28] Cow parsnip

[15] Western meadow rue

[20] Canada violet

[3] Fireweed

[1] Horsetail

[10] White geranium

[3] Dandelion

Graminoids

[37] Marsh reedgrass

[1] Sedge

[29] Timothy

[2] Mountain brome

\section{SITE CHARACTERISTICS}

Moisture regime: subhygric

Nutrient regime: rich

Topographic position: lower slope, midslope

Slope: $(0-8 \%)$

Aspect: south, level, north

\section{SOIL CHARACTERISTICS}

Organic thickness: (6-15)

Humus form: moder

Surface texture: SL,SiL, L,C

Effective texture: $\mathrm{CL}, \mathrm{SiL}, \mathrm{SCL}$,

Depth to Mottles/Gley: none, (0-25)

Drainage: well, mod. well

Parent material: F, C, M, X

Soil subgroup: O.EB, E.DYB, O.EB, BR.GL

SASMC8 Marsh reedgrass-Timothy/Cow parsnip/(n=1) 
i fen $(\mathrm{n}=10)($ taken from Ecosites of WestCentral Alberta)

\section{GENERAL DESCRIPTION}

The rich and poor fen are combined in this ecosite. The fen ecosite is generally characterized by flowing oxygenated water and alkaline, nutrientrich conditions. This ecosite occupies level, depressional and lower slope positions where impeded drainage or high water tables enhance the accumulation of organic matter consisting of sedges, golden moss, tufted moss, and brown moss. Black and/or Engelmann spruce dominate the canopy of the treed phase, while dwarf birch or willow form the canopy of the shrubby phase and sedges dominate the graminoid phase.

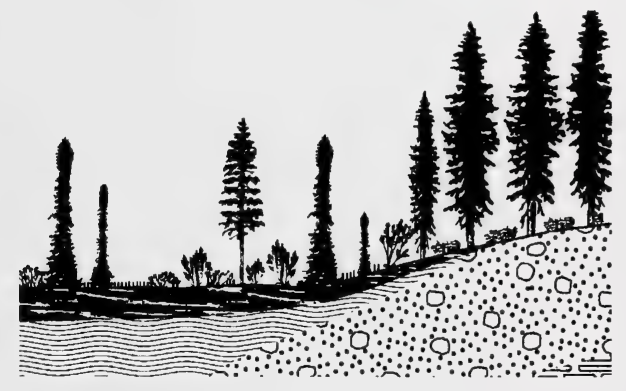

\section{SUCCESSIONAL RELATIONSHIPS}

The fen is an early stage in hydarch succession. Species composition, direction, and rate of succession changes with changing hydrologic regime. As with other wetlands, rich fens have slow successional rates so recovery from disturbance may also be slow.

\section{INDICATOR SPECIES}

Black spruce

Engelmann spruce

Willow

Labrador tea

Dwarf birch

Horsetail

Sedge

Golden moss

Brown moss

Tufted moss subhydric/rich

\section{SITE CHARACTERISTICS}

Moisture regime: subhygric, hygric, subhydric,hydric

Nutrient regime: rich, very rich, medium

Topographic position: level, depression, toe

Slope: level, (0-1\%)

Aspect: level, southerly, easterly

\section{SOIL CHARACTERISTICS}

Organic thickness: $(>80)(60-79)$

Humus form: mor, peaty mor

Surface texture: fibric, mesic

Effective texture: fibric, mesic

Depth to Mottles/Gley: not applicable

Drainage: imperfect, poor, very poor

Parent material: $\mathrm{O}$

Soil subgroup:R.G, TY.M, TY.F, T.M, T.F, R.HG, O.HG, O.G, FI.M

\section{ECOSITE PHASES}

\author{
i1 shrub fen $(\mathrm{n}=5)$ \\ i2 graminoid fen $(n=4)$ \\ i3 treed fen $(n=1)$
}


i1 shrubby fen $(\mathrm{n}=5)$

\section{CHARACTERISTIC SPECIES}

\section{Shrub}

\section{[25] Willow}

[5] Shrubby cinquefoil

[3] Dwarf birch

\section{Forb}

[3] Lindley's aster

[6] Strawberry

[4] Arrow leaved coltsfoot

[2] Horsetail

[1] Cow parsnip

\section{Grass}

\section{[25] Sedge}

[2] Tufted hairgrass

[6] Baltic rush

[2] Tufted hairgrass

\section{Parent material: $\mathrm{O}$}

Soil subgroup:R.G, TY.M, TY.F, T.M, T.F, R.HG, O.HG, O.G, FI.M

\section{PLANT COMMUNITY TYPES}

SASMB1 Willow/Sedge $(n=3)$

SASMB5 Willow/Marsh reedgrass $(\mathrm{n}=2)$

\section{SITE CHARACTERISTICS}

Moisture regime: subhygric, subhydric

Nutrient regime: very rich, rich medium

Topographic position: level, depression

Slope: level, $(0-2 \%)$

Aspect: variable

\section{SOIL CHARACTERISTICS}

Organic thickness: $(>80)(60-79)$

Humus form: mor, peaty mor

Surface texture: fibric, mesic

Effective texture: fibric, mesic

Depth to Mottles/Gley: not applicable

Drainage: imperfect, poor, very poor 


\section{CHARACTERISTIC SPECIES}

Shrub

[1] Willow

Forb

[ 1 ] Northern bedstraw

[1] Fireweed

\section{Grass}

[ 81 ]Water sedge

[4] Tufted hairgrass
Parent material: $\mathrm{O}$

Soil subgroup:R.G, TY.M, TY.F, T.M, T.F, R.HG, O.HG, O.G, FI.M

\section{PLANT COMMUNITY TYPES}

SASMA1 Sedge meadows $(n=4)$

\section{SITE CHARACTERISTICS}

Moisture regime: hygric, subhydric

Nutrient regime: very rich, rich

Topographic position: level, depression

Slope: level, $(0-2 \%)$

Aspect: variable

\section{SOIL CHARACTERISTICS}

Organic thickness: $(>80)(60-79)$

Humus form: mor, peaty mor Surface texture: fibric, mesic Effective texture: fibric, mesic

Depth to Mottles/Gley: not applicable

Drainage: imperfect, poor 
i3 treed fen $(\mathrm{n}=1)$

\section{CHARACTERISTIC SPECIES}

Tree

[35 ] White spruce

Shrubs

[19] Willow

[20] Labrador tea

[12] Bog birch

Forbs

[12] Small bog cranberry

[6] Twinflower

[2] Mitrewort

Graminoids

[5] Sedge

[2] Baltic rush

\section{COMMUNITY TYPES}

\section{SASME5 Sw/Willow-Labrador tea $(n=1)$}

\section{SITE CHARACTERISTICS}

Moisture regime: subhydric, hygric

Nutrient regime: rich

Topographic position: toe

Slope: level

Aspect: variable

\section{SOIL CHARACTERISTICS}

Organic thickness: $16-25$

Humus form: peatmor

Surface texture: humic

Effective texture: SCL

Depth to Mottles/Gley: (0-25)

Drainage: poor

Parent material: F

Soil subgroup: O.HG 
Table 5. Native grass and shrublands organized by ecological range site for the Southern Rocky Moutains of the Subalpine subregion

$\begin{array}{lllll}\begin{array}{l}\text { Community } \\ \text { number }\end{array} & \text { Community type } & \text { Productivity }(\mathrm{kg} / \mathrm{ha}) & \text { Carrying } \\ \text { capacity (ha/AUM) }\end{array}$

\begin{tabular}{lllllllll}
\hline 22 & grassland & $\mathbf{2 7 4}$ & $\mathbf{3 9 0}$ & $\mathbf{2 9 2}$ & $\mathbf{8 1 0}$ & Xeric & Rapidly & $\mathbf{3 . 0}$ \\
SASMA13 & Fescue-Junegrass/E.yellow locoweed512 & 291 & 192 & $\mathbf{9 9 4}$ & Subxeric & Very rapidly & 2.0 \\
SASMA14 & White mountain avens & 36 & 198 & 392 & 626 & Very xeric & Rapidly & 40.0 \\
SASMA17 & Bluebunch wheatgrass-Sedge & $\mathbf{6 0 0}$ & 350 & 200 & 1150 & Xeric & Rapidly & 2.0 \\
b2 & grassland & $\mathbf{9 3 2}$ & $\mathbf{6 1 7}$ & $\mathbf{1 8 6}$ & $\mathbf{1 5 1 0}$ & Submesic & Rapidly & $\mathbf{1 . 0}$ \\
SASMA2. & Rough fescue-Sedge & 1380 & 676 & 49 & 1917 & Mesic & Well & 0.7 \\
SASMA3. & Rough fescue-Hairy wildrye & 1326 & 653 & 171 & 1662 & Submesic & Rapidly & 0.7 \\
SASMA3a & Hairy wildrye-Rough fescue-Sedge & - & - & - & 1225 & Submesic & Well & 0.7 \\
SASMA6. & Yellow mountain avens & 572 & 602 & 0 & $1372 *$ & Mesic & Rapidly & 40.0 \\
SASMA9 & Rough fescue-Sedge/Bearberry & $\mathbf{6 9 5}$ & 285 & 680 & 1542 & Subxeric & Rapidly & 1.5 \\
SASMA10 & Parry oatgrass-Sedge & 732 & 702 & 96 & 1452 & Subxeric & Rapidly & 0.7 \\
b2a & grazed grassland & $\mathbf{9 7 6}$ & $\mathbf{6 7 1}$ & $\mathbf{2 8 9}$ & $\mathbf{1 9 4 3}$ & Submesic & Rapidly & $\mathbf{1 . 0}$ \\
SASMA4. & Sedge-Hairy wildrye-Slender & & & & & & & \\
& wheatgrass & 1116 & 683 & 56 & 1891 & Submesic & Well & 0.8 \\
SASMA11 & Sedge/Bearberry & 733 & 391 & 1051 & 2175 & Xeric & Rapidly & 1.7 \\
SASMC2. & Parry oatgrass-Kentucky bluegrass- & 1140 & 685 & 79 & 1894 & Subxeric & Rapidly & 0.8 \\
& Sedge & & & & & & & \\
SASMC4. & Fringed sage/Kentucky bluegrass- & 704 & 490 & 236 & 1430 & Xeric & Rapidly & 1.0 \\
SASMC9 & Parry oatgrass & Idaho fescue-Rough fescue/Bearberry1408 & 862 & 43 & 2313 & Submesic & Well & 1.6 \\
SASMC13 & Idaho fescue-Sheep fescue-bluegrass & & & 1500 & Submesic & Well & 1.0 \\
b3 & shrubland & $\mathbf{5 7 2}$ & $\mathbf{4 2 1}$ & $\mathbf{2 3 5}$ & $\mathbf{1 2 2 8}$ & Subxeric & Rapidly & $\mathbf{1 . 5}$ \\
SASMB2. & Willow/Richardson needlegrass & - & - & - & N/A & Submesic & Well & 4.0 \\
SASMB7 & Smooth willow-Juniper & & & & & & & \\
& Hairy wildrye & 572 & 421 & 235 & 1228 & Subxeric & Rapidly & 1.2
\end{tabular}

Table 5 cont'd 


\begin{tabular}{|c|c|c|c|c|c|c|c|c|}
\hline \multirow{2}{*}{$\begin{array}{l}\text { Community } \\
\text { number }\end{array}$} & \multirow[t]{2}{*}{ Community type } & \multirow[b]{2}{*}{ Grass } & \multicolumn{3}{|c|}{ Productivity (kg/ha) } & \multirow[b]{2}{*}{ Moisture } & \multirow[b]{2}{*}{ Drainage } & \multirow{2}{*}{$\begin{array}{l}\text { Carrying } \\
\text { capacity (ha/AUM }\end{array}$} \\
\hline & & & Forb & Shrub & Total & & & \\
\hline cc1 & rough fescue & 1117 & 400 & 23 & 1526 & Mesic & Well & 0.6 \\
\hline SASMA2a. & Rough fescue-Richardson & & & & & & & \\
\hline & needlegrass & 1088 & 186 & - & 1237 & Mesic & Well & 0.7 \\
\hline SASMA8 & $\begin{array}{l}\text { Rough fescue-Idaho fescue-Parry } \\
\text { oatgrass }\end{array}$ & 1146 & 614 & 55 & 1815 & Submesic & Well & 0.5 \\
\hline ce1a & grazed rough fescue & 2154 & 762 & 10 & 2670 & Mesic & Well & 0.7 \\
\hline SASMC1. & Parry oatgrass-Rough fescue- & & & & & & & \\
\hline & Kentucky bluegrass & 1160 & 712 & 24 & 1574 & Xeric & Rapidly & 0.6 \\
\hline SASMC3. & $\begin{array}{l}\text { Meadow foxtail-Kentucky bluegrass } \\
\text { Parry oatgrass }\end{array}$ & 2775 & 507 & - & 3282 & Mesic & Well & 0.5 \\
\hline SASMC5. & Rough fescue-Kentucky bluegrass & - & - & - & $2000^{*}$ & Mesic & Well & $0.6^{*}$ \\
\hline SASMC6. & Kentucky bluegrass-Rough fescue & 1382 & 887 & 14 & 2258 & Mesic & Rapidly & 0.8 \\
\hline SASMC7 & $\begin{array}{l}\text { Timothy-K. bluegrass } \\
\text { /Fireweed }\end{array}$ & 3300 & 940 & - & 4240 & Submesic & Rapidly & 0.5 \\
\hline cc2 & shrubland & 405 & 356 & 358 & 1369 & Mesic & Well & 1.4 \\
\hline SASMA12 & Sliverberry-Rose & & & & $500^{*}$ & Subxeric & Rapidly & 1.8 \\
\hline SASMB6 & Smooth willow-Shrubby cinquefoil & & & & & & & \\
\hline & Hairy wildrye & 810 & 712 & 716 & 2238 & Mesic & Well & 1.0 \\
\hline cc3 & forb meadow & 554 & 734 & 125 & 1413 & Mesic & Well & 1.0 \\
\hline SASMA16 & Forb meadow & 554 & 734 & 125 & 1413 & Submesic & Well & 0.6 \\
\hline e2 & false azalea-grouseberry $\mathbf{P w}$ & - & - & - & N/A & Mesic & Rapidly & 40.0 \\
\hline SASMB3. & Whitebark pine & - & - & - & N/A & Submesic & Rapidly & 40.0 \\
\hline e6 & grassland & 1039 & 591 & 94 & 2037 & Subxeric & Rapidly & 0.8 \\
\hline SASMA15 & Pinegrass-Hairy wildrye/Strawberry & 758 & 1170 & 110 & 2037 & Subxeric & Rapidly & 0.8 \\
\hline
\end{tabular}

Community

Community type

Productivity (kg/ha)

Carrying 


\begin{tabular}{|c|c|c|c|c|c|c|c|c|}
\hline number & & Grass & Forb & Shrub & Total & Moisture & Drainage & capacity (ha/AUM) \\
\hline SASMC11 & Creeping red fescue/Clover & 1916 & 152 & 52 & 2120 & Mesic & Well & 0.5 \\
\hline SASMC12 & Rose/Pinegrass & 444 & 452 & 120 & 1016 & Mesic & Well & 1.0 \\
\hline e7 & shrubland & 150 & 100 & 1000 & 1250 & Subhygric & Mod.Well & 3.6 \\
\hline SASMB9 & Bebb willow/Pinegrass & 150 & 100 & 1000 & 1250 & Subhygric & Mod.Well & 3.6 \\
\hline f4 & shrubby seepages & - & - & - & $2000^{*}$ & Subhygric & Mod. Well & 0.8 \\
\hline SASMA7a & Marsh reedgrass/Cow parnsip & - & - & - & $2000^{*}$ & Subhygric & Mod. Well & 0.8 \\
\hline f4a & grazed shrubby seepage & 4030 & 863 & 33 & 4926 & Subhygric & Mod. Well & 0.8 \\
\hline SASMC8 & $\begin{array}{l}\text { Marsh reedgrass-Timothy/Cow } \\
\text { parsnip }\end{array}$ & 4030 & 863 & 33 & 4926 & Subhygric & Mod. Well & 0.8 \\
\hline g1 & dwarf birch/tufted hairgrass & - & - & - & 1668 & Hygric & Mod. Well & 0.8 \\
\hline \multirow[t]{2}{*}{ SASMA1a } & Awned sedge-Alpine foxtail- & & & & & & & \\
\hline & Tufted hairgrass & & & & $2000^{*}$ & Subhygric & Mod. Well & 0.7 \\
\hline SASMA7 & Tufted hairgrass-Sedge & 1164 & 162 & 0 & 1326 & Subhygric & Mod. Well & 0.8 \\
\hline g1a & grazed birch/tufted hairgrass & 1533 & 278 & 64 & 2154 & Hygric & Mod. Well & 1.0 \\
\hline SASMB4 & Willow-Birch/R.fescue-K.bluegrass & 250 & 450 & 1004 & 1404 & Subhygric & Mod. Well & 1.1 \\
\hline \multirow[t]{2}{*}{ SASMB8 } & Willow/Tufted hairgrass- & & & & & & & \\
\hline & Kentucky bluegrass & 1734 & 248 & - & 1982 & Subhygric & Mod.Well & 1.0 \\
\hline SASMC10 & Tufted hairgrass-Kentucky bluegrass & 2792 & 405 & - & 3197 & Subhygric & Mod. Well & 0.9 \\
\hline SASMA5. & Kentucky bluegrass/Dandelion & 1708 & 403 & 104 & 2033 & Subhygric & Mod. Well & 0.9 \\
\hline i1 & shrub fen & 1207 & 244 & 756 & 2150 & Subhydric & Poorly & 1.0 \\
\hline SASMB1. & Willow/Sedge & 1513 & 400 & 236 & 2150 & Hygric & Poorly & 1.0 \\
\hline SASMB5 & Willow/Marsh reedgrass & 900 & 88 & 1276 & 1916 & Subhygric & Imperfectly & 1.0 \\
\hline i2 & graminoid fen & 1636 & 109 & $\mathbf{0}$ & 1745 & Subhydric & Poorly & 0.5 \\
\hline SASMA1. & Water sedge & 1636 & 109 & 0 & 1745 & Subhydric & Poorly & 0.5 \\
\hline
\end{tabular}

*Estimate 


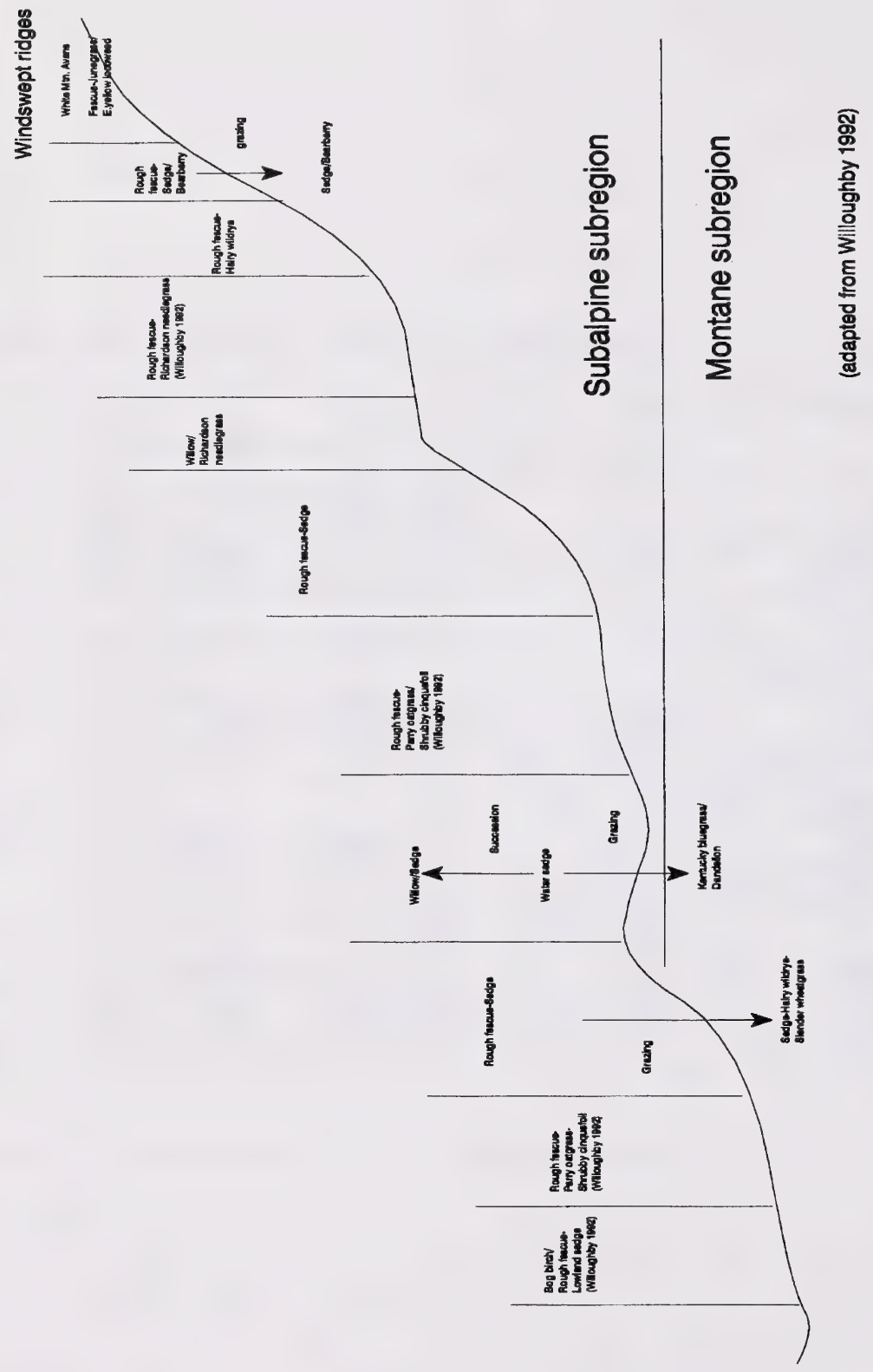

Figure 7. Grassland and shrubland community types in the landscape of the Montane and Subalpine subregions of southern Alberta. 
Key to grass and shrubland dominated communities in the Southern mountains of the Subalpine subregion.

1. Timberline communities or windswept ridges at timberline..................................... 2

Meadow communities or south facing grasslands at lower elevations...................... 4

2. Mesic plant community dominated by Whitebark pine or willow.....................................2a

Windswept ridges dominated by white mtn. avens, Idaho fescue, junegrass, willow or juniper.

2a Plant community dominated by Whitebark pine SASMB3

Lower slope position dominated by willow with scattered trees............................SASMB6

3. Community has scattered willow and juniper and is dominated by Hairy wildrye..............3b

Community dominated by white $\mathrm{mtn}$. avens, Idaho fescue or Junegrass.................. $3 \mathbf{3 a}$

3a. Community dominated by white mtn. avens. SASMA14

Grass dominated community dominated by Idaho fescue and Junegrass...............SASMA13

3b Smooth willow, hairy wildrye dominated site. SASMB7

Bebb willow, pinegrass dominated site.

SASMB9

4. Moist meadows or gravelly river flats dominated by shrubs, tufted hairgrass, sedge, yellow mtn. avens or silverberry.....

Drier south and north facing slopes dominated by rough fescue, parry oatgrass, upland sedges, hairy wildrye, pinegrass, bluebunch wheatgrass or forb dominated meadows with fireweed. 13

5 . Dry gravelly river flats dominated by yellow $\mathrm{mtn}$. avens, Idaho fescue or silverberry... 6

Moist sites dominated by willow, bog birch or grassy areas dominated by tufted hairgrass, sedge, marsh reedgrass, kentucky bluegrass and dandelion.

6. Site dominated by yellow mtn. avens. .SASMA6

Site dominated by silverberry or Idaho fescue and Canada bluegrass.

6a. Site is a grazed grassland dominated by Idaho fescue and Canada bluegrass Site is dominated by silverberry. $.6 a$

7. Willow or bog birch dominated community types. SASMC13

Grass dominated meadows (tufted hairgrass, marsh reedgrass, alpine foxtail,awned sedge, water sedge, kentucky bluegrass). SASMA12

8. Wetter sites dominated by sedge,tufted hairgrass or marsh reedgrass 11

Drier, sites dominated by richardson needlegrass or rough fescue in understory...... 10

9. Understory dominated by tufted hairgrass. SASMB8

Understory dominated by marsh reedgrass or sedge species.

9a. Understory dominated by marsh reedgrass. SASMB5

Understory dominated by sedge.

SASMB1

10. Dry south facing slopes in Athabasca river valley near Jasper, dominated by Richardson needlegrass in understory. SASMB2

Understory dominated by rough fescue. SASMB4

11 . Very wet sites dominated by water sedge.

SASMA1

Drier sites dominated by tufted hairgrass, graceful sedge, marsh reedgrass, alpine foxtail or Kentucky bluegrass.

12

12 Ungrazed sites dominated by tufted hairgrass, awned sedge, alpine foxtail, marsh reedgrass, or graceful sedge.

12a

Grazed sites dominated by Kentucky bluegrass, timothy or dandelion.

12b

12a Marsh reedgrass and cow parsnip dominated grassy meadows. SASMA7a

Tufted hairgrass, beaked sedge, alpine foxtail or graceful sedge dominated meadow. $.12 \mathrm{c}$

12b Marsh reedgrass, timothy, cow parsnip dominated meadows. SASMC8

Heavy grazing pressure site dominated by Kentucky bluegrass and dandelion.....SASMA5

12c Tufted hairgrass, graceful sedge dominated meadows. Awned sedge, Alpine foxtail dominated meadow SASMA7

13. Ungrazed rough fescue, hairy wildrye, bluebunch wheatgrass, pinegrass or SASMA1a 
forb dominated grasslands.

Moderately to heavily grazed grasslands

14. Pinegrass or forb (fireweed) dominated meadows

Rough fescue, bluebunch wheatgrass, parry oatgrass, hairy wildrye, bearberry dominated grasslands

15 Site dominated by forbs, moist seepage area.

16

Pinegrass, hairy wildrye dominated grassland.

SASMA16

SASMA15

16. Rough fescue or bluebunch wheatgrass dominated grasslands, south and west of Turner valley, hairy wildrye and sedge dominate or co-dominate grassland.

17

Rough fescue dominated grasslands, west of Porcupine Hills and in Castle area, co-dominated by Parry oatgrass, sedge or bearberry

18

17. Grasslands of south facing slopes and benches, sedge, Richardson needlegrass codominated.

$17 \mathrm{~b}$

Grasslands of lower slope positions or north aspects, dominated or co-dominated by hairy wildrye...

17a Grassland dominated by hairy wildrye, north aspects on steep ridges..

17a

Grasslands co-dominated by hairy wildrye, south facing

$17 \mathrm{~b}$ Terrace grasslands co-dominated by Richardson needlegrass.

SASMA3a

SASMA3

Grasslands on slopes co-dominated by sedge or Bluebunch wheatgrass.

SASMA2a

7c Rough fescue-Sedge dominated grassland. 17c

Bluebunch wheatgrass-Sedge dominated grassland

SASMA2

18. Grasslands of lower slope positions dominated by Rough fescue.

SASMA17

SASMA8

Grasslands of mid to upper slope positions dominated by Parry oatgrass, Idaho fescue or

bearberry.....

19. Grasslands of midslope position dominated by Parry oatgrass, Idaho fescue

Grasslands of upper slope positions or hillcrests co-dominated by bearberry.

20. Moderately grazed grasslands native grass species still dominate the site.

Heavily grazed grasslands non-native species (Kentucky bluegrass, timothy, meadow foxtail) dominate or co-

dominate the site.

22

21 Drier sites with bearberry

21a

Moister sites dominated by sedge, hairy wildrye,tufted hairgrass or slender wheatgrass.. 21b

21a Grassy areas with a high cover of Idaho fescue and Rough fescue

SASMC9

Sedge dominates the grass layer

SASMA11

$21 \mathrm{~b}$ Well drained sites dominated by sedge, hairy wildrye or wheatgrass.

SASMA4

Mod. well drained sites dominated by tufted hairgrass

SASMC10

22. Old range improvement dominated by meadow foxtail

SASMC3

Meadow foxtail not present grazed or range improvement sites.

23 Kentucky bluegrass or timothy dominated sites.

Kentucky bluegrass only co-dominate, Parry oatgrass or rough fescue or fringed sage or C. red fescue or

pinegrass dominates

24. Timothy dominated community.

SASMC7

Kentucky bluegrass, dandelion dominated.

SASMC6

25. Rough fescue dominates the site

SASMC5

Parry oatgrass, C. red fescue, pinegrass or Fringed sage dominates the site.

26

26. Hillcrests and south facing slopes dominated by fringed sage

SASMC4

Parry oatgrass dominated community types

27

27. Parry oatgrass with Rough fescue and Kentucky bluegrass, lower slope.

SASMC1

Little rough fescue present, midslope position with C. red fescue or pinegrass.

.28

28. Drier sites dominated by Parry oatgrass.

SASMC2

Creeping red fescue, Pinegrass or Rose dominated sites.

.29

29. Creeping red fescue dominated range improvement site.

SASMC11

Old range improvement site dominated by rose and pinegrass.

SASMC12 


\section{SASMA1. Water sedge \\ (Carex aquatilis)}

$\mathrm{n}=\mathbf{4}$ This community type is found in all ecodistricts of the subalpine. Wet conditions and periodic flooding result in the formation of water sedge meadows. Willow will invade into the drier edges of these meadows to form the Willow/Water sedge community type. These community types are quite productive producing nearly 2000 $\mathrm{kg} / \mathrm{ha}$ of forage, but the high water table in the spring and summer when these meadows are most palatable limits livestock use. A study in the Yukon found that crude protein on these meadows declined from a high of $10 \%$ in May to less than 5\% in September (Bailey et al. 1992). As a result, these meadows would be rated as secondary or non-use range.

\section{Plant Composition Canopy Cover(\%) Mean Range Const.}

\section{SHRUBS}

WILLOW

(Salix spp.)

$\mathrm{T}$

-

25

FORBS

FIREWEED

(Epilobium angustifolium) T

NORTHERN BEDSTRAW

(Galium boreale)

1

GraSSES

WATER SEDGE

(Carex aquatilis)

74

TUFTED HAIRGRASS

(Deschampsia cespitosum) 3
0-5

25

$0-1$

50

$52-93 \quad 100$
-100

$0-9 \quad 75$

\section{ENVIRONMENTAL VARIABLES}

MOISTURE REGIME :

SUBHYDRIC

NUTRIENT REGIME:

MESOTROPHIC

ELEVATION:

$$
\text { 1600-1981(1859) M }
$$

SOIL DRAINAGE:

POORLY

ECOLOGICAL STATUS SCORE: 24

Forage Production

$\begin{array}{ll}\text { GRASS } & 1636(636-2636) \\ \text { FORB } & 109(0-218) \\ \text { TOTAL } & 1745(636-2854)\end{array}$

ECOLOGICALLY SUSTAINABLE STOCKING RATE GENERALLY NON-USE $0.5(40.0-0.3) \mathrm{HA} / \mathrm{AUM}$ $0.81(.01 .35) \mathrm{AUM} / \mathrm{AC}$ 


\section{SASMA1a. Awned sedge-Alpine foxtail-Tufted hairgrass \\ (Carex atherodes-Alopecurus occidentalis-Deschampsia cespitosa)}

$\mathbf{n}=\mathbf{1}$ This community type was described in a meadow adjacent to a small creek. It is similar to the previously described water sedge community, but this community type is better drained which favours the growth of awned sedge, alpine foxtail and tufted hairgrass. On the drier edges of this community type upland grass species like rough fescue and Idaho fescue can be found. Willoughby (1992) has found that beaked sedge is palatable to livestock, which causes these meadows to be regularly grazed. Heavy grazing will allow Kentucky bluegrass, timothy and dandelion to invade onto these sites.

\section{Plant Composition Canopy Cover(\%)} Mean Range Const.

\section{SHRUBS}

WILLOW

(Salix spp.)

FORBS

FIREWEED

(Epilobium angustifolium) 3

MARSH CINQUEFOIL

(Poa palustre)

SMOOTH ASTER

(Aster laevis)

MOUNTAIN CINQUEFOIL

(Potentilla diversifolia) 15

\section{GRASSES}

AWNED SEDGE

(Carex atherodes)

TUFTED HAIRGRASS

(Deschampsia cespitosum) 10

ALPINE FOXTAIL

(Alopecurus occidentalis) 22

IDAHO FESCUE

(Festuca idahoensis)

TIмотну

(Phleum pratense)

$18 \quad-\quad 100$

$15 \quad-\quad 100$

100

100

100

100

$40 \quad-\quad 100$

\section{ENVIRONMENTAL VARIABLES}

MOISTURE REGIME :

SUBHYGRIC

NUTRIENT REGIME:

PERMESOTROPHIC

ELEVATION:

$1640 \mathrm{M}$

SOIL DRAINAGE:

MODERATELY WELL

ECOLOGICAL STATUS SCORE: 24

Forage Production

Total $\quad 2000 *$ Estimate

ECOLOGICALLY SUSTAINABLE STOCKING RATE

$0.7(0.9-0.5) \mathrm{HA} / \mathrm{AUM}$ or $.57(.45-0.8) \mathrm{AUM} / \mathrm{AC}$ 


\section{SASMA2. Rough fescue-Sedge \\ (Festuca scabrella-Carex spp.)}

$\mathbf{n = 1 8}$ This community type appears to be the modal grassland community type found on level and gentle south -facing slopes in the Southern Rocky Mountains of the Subalpine subregion. The dominance of rough fescue indicates that this grassland is transitional from the lower Montane subregion. As one moves up in elevation there is a shift away from a Rough fescue-Parry oatgrass dominated community type to a Rough fescue Sedge dominated community type. Willoughby (1992), found that blunt sedge replaced Parry oatgrass as dominant or codominant on steep south-facing slopes, and Richardson needlegrass replaced Parry oatgrass as codominant on more mesic sites in this area. Jaques (1976), described a similar community type from Plateau Mountain to Mount Allan. He felt this community type represented critical wildlife habitat because it remained snow-free for a majority of the winter. Grazing by livestock on these community types should be managed carefully in order to maintain a carryover for wildlife in the winter.

Plant Composition Canopy Cover(\%) Mean Range Const.

SHRUBS

SHRUBBY CINQUEFOIL

(Potentilla fruticosa)

$6 \quad 0-19 \quad 93$

FORBS

YARROW

(Achillea millefolium)

6

$2-17 \quad 100$

YelLow BEARDSTONGUE

(Penstemon confertus)
MOUSE EARED CHICKWEED

(Cerastium arvense) 2

BEARBERRY

(Arctostaphylos uva-ursi) 4

STRAWBERRY

(Fragaria virginiana)

OLD MANS WHISKER'S

(Geum triflorum)

4

4

0-11 50

$1-6 \quad 100$

$0-25 \quad 39$

$0-13 \quad 78$

$0-18 \quad 83$

Grasses

ROUGH FESCUE

(Festuca scabrella)

BLUNT SEDGE

(Carex obtusata)

CALIFORNIA OATGRASS

(Danthonia californica) 11

RICHARDSON NEEDLEGRASS

(Stipa richardsonii) 1

HAIRY WILDRYE

(Elymus innovatus)

PARRY OATGRASS

(Danthonia parryi)

$11 \quad 0-28 \quad 89$

$0-43 \quad 83$

$0-5 \quad 33$

$6 \quad 0-34 \quad 72$

$4 \quad 0-17 \quad 56$

\section{ENVIRONMENTAL VARIABLES}

MOISTURE REGIME:

SUBMESIC-MESIC

NUTRIENT REGIME : MESOTROPHIC

ELEVATION: 1460-2024(1756) M

SOIL DRAINAGE:

WELL

SLOPE: $0-48(15) \%$

ASPECT SOUTHERLY

ECOLOGICAL STATUS SCORE: 24 OR 16

\section{Forage Production Kg/Ha}
GRASS 1380 (748-1972)
FORB $676(224-1412)$
SHRUB 49(0-296)
TOTAL 1917(900-3103)

\section{ECOLOGICALLY SUSTAINABLE STOCKING RATE}

$0.7(0.9-0.5) \mathrm{HA} / \mathrm{AUM}$ or

$0.57(0.45-0.8) \mathrm{AUM} / \mathrm{AC}$ 


\section{SASMA2a. Rough fescue-Richardson needlegrass (Festuca scabrella-Stipa richardsonii)}

$\mathbf{n}=\mathbf{6}$ This community type occupies benches and gentle south facing slopes in the Southern Rocky Mountains of the Subalpine subregion. Jaques (1980) described a Richardson needlegrass-rough fescue dominated grassland at higher elevations on the northern edge of the foothills. Richardson needlegrass appears to supplant Parry oatgrass as the co-dominant grass on mesic benchlands above $1700 \mathrm{~m}$. This community type is very similar to the Rough fescue-Sedge dominated community, but lacks the high cover of Richardson needlegrass. The Rough fescue-Sedge community may represent a grazing disclimax of this community type.

Plant Composition Canopy Cover(\%)

SHRUBS

$$
\text { Mean Range Const. }
$$

SHRUBBY CINQUEFOIL

(Potentilla fruticosa)

$2 \quad 0-10 \quad 50$

\section{FORBS}

YARROW

\begin{tabular}{|c|c|c|c|}
\hline (Achillea millefolium) & 2 & $0-4$ & 83 \\
\hline YELLOW BEARDSTONGUE & & & \\
\hline (Penstemon confertus) & 10 & $0-39$ & 50 \\
\hline MOUSE EARED CHICKWEE & & & \\
\hline (Cerastium arvense) & 2 & $1-4$ & 100 \\
\hline STRAWBERRY & & & \\
\hline (Fragaria virginiana) & 3 & $0-8$ & 0 \\
\hline EARLY YELLOW LOCOWE & & & \\
\hline (Oxytropis sericea) & 2 & $0-9$ & 50 \\
\hline
\end{tabular}

\section{Grasses}

ROUGH FESCUE

$\begin{array}{lccc}\begin{array}{l}\text { (Festuca scabrella) } \\ \text { PARRY OATGRASS }\end{array} & 20 & 10-42 & 100 \\ \begin{array}{l}\text { (Danthonia parryi) } \\ \text { CALIFORNIA OATGRASS }\end{array} & 4 & 0-7 & 67 \\ \begin{array}{l}\text { (Danthonia californica) } \\ \text { RICHARDSON NEEDLEGRASS } \\ \text { (Stipa richardsonii) }\end{array} & 13 & 7-22 & 100 \\ \begin{array}{l}\text { SLENDER WHEATGRASS } \\ \text { (Agropyron trachycaulum) } 4\end{array} & 1-7 & 100 \\ \begin{array}{l}\text { IDAHO FESCUE } \\ \text { (Festuca idahoensis) }\end{array} & 1 & 1-3 & 100\end{array}$

\section{ENVIRONMENTAL VARIABLES}

MOISTURE REGIME:

SUBMESIC-MESIC

NUTRIENT REGIME :

MESOTROPHIC

ELEVATION:

1709(1592-2042)M

SOIL DRAINAGE:

RAPIDLY-WELL

SLOPE: $10(2-26) \%$

ASPECT SOUTHERLY

ECOLOGICAL STATUS SCORE: 24

Forage Production Kg/HA

$\begin{array}{ll}\text { GRASS } & 1088 \\ \text { FORB } & 186 \\ \text { TOTAL } & 1237(1200-1274)\end{array}$

ECOLOGICALLY SUSTAINABLE STOCKING RATE $0.7(0.9-0.7) \mathrm{HA} / \mathrm{AUM} \mathrm{OR}$ $0.57(0.45-0.57) \mathrm{AUM} / \mathrm{AC}$ 


\section{SASMA3. Rough fescue-Hairy wildrye \\ (Festuca scabrella-Elymus innovatus)}

$\mathbf{n = 1 1}$ This community is similar to the Rough fescue-Sedge and R.fescue-Needlegrass dominated community types previously described, but it is found on drier, steeper slopes with poorer soils than the other rough fescue dominated types. As one moves upslope there is a shift in co-dominance of sedge to hairy wildrye and an increase in cover of bearberry and juniper.

Corns and Achuff (1982), described hairy wildrye dominated community types on south facing slopes in the more northern ecodistricts. They felt these grasslands occurred on areas with frequent snow avalanching. It is possible that this community type is associated with deeper snow accumulation than the Rough fescue-Sedge dominated type previously described.

Plant COMPOSITION CANOPY COVER(\%) Mean Range Const.

\section{SHRUBS}

SHRUBBY CINQUEFOIL.

$\begin{array}{llll}\begin{array}{l}\text { (Potentilla fruticosa) } \\ \text { CREEPING JUNIPER }\end{array} & 4 & 0-23 & 91 \\ \begin{array}{l}\text { (Juniperus horizontalis) } \\ \text { Junerus }\end{array} & 2 & 0-9 & 27\end{array}$

\section{FORBS}

BEARBERRY

$\begin{array}{lccc}\begin{array}{l}\text { (Arctostaphylos uva-ursi)4 } \\ \text { YARROW }\end{array} & 0-16 & 36 \\ \begin{array}{l}\text { (Achillea millefolium) } \\ \text { STRAWBERRY }\end{array} & 3 & 1-6 & 100 \\ \begin{array}{l}\text { (Fragaria virginiana) } \\ \text { YELLOW HEDYSARUM } \\ \text { (Hedysarum sulphurscens) } 3\end{array} & 4 & 1-9 & 100 \\ \begin{array}{l}\text { SILVERY PERENNIAL LUPINE } \\ \text { (Lupinus argenteus) }\end{array} & 2 & 0-9 & 55\end{array}$

\section{Grasses}

HAIRY WILDRYE

$\begin{array}{llll}\begin{array}{c}\text { (Elymus innovatus) } \\ \text { BLUNT SEDGE } \\ \text { (Carex obtusata) }\end{array} & 21 & 4-57 & 100 \\ \begin{array}{c}\text { ROUGH FESCUE } \\ \begin{array}{c}\text { (Festuca scabrella) } \\ \text { PARRY OATGRASS }\end{array}\end{array} & 34 & 8-57 & 100 \\ \begin{array}{c}\text { (Danthonia parryii) } \\ \text { (E) }\end{array} & 4 & 0-24 & 46\end{array}$

\section{ENVIRONMENTAL VARIABLES}

MOISTURE REGIME:

SUBMESIC -MESIC

NUTRIENT REGIME :

SUBMESOTROPHIC-MESOTROPHIC

ELEVATION:

SOIL DRAINAGE:

1620-2042(1854)M

RAPIDLY

SLOPE:

$$
4-55(26) \%
$$

ASPECT:

SOUTHERLY

ECOLOGICAL STATUS SCORE: 24

\section{Forage Production Kg/HA}

$$
\begin{array}{ll}
\text { GRASS } & 1326(1120-1440) \\
\text { FORB } & 653(316-1176) \\
\text { SHRUB } & 171(0-308) \\
\text { TOTAL } & 1662(900-2502)
\end{array}
$$

ECOLOGICALLY SUSTAINABLE STOCKING RATE $0.7(1.0-0.6) \mathrm{HA} / \mathrm{AUM}$ OR 0.57(0.4-0.67) AUM/AC 


\section{SASMA3a. Hairy wildrye- Rough fescue -Carex spp. (Elymus innovatus- Festuca scabrella-Sedge)}

$\mathbf{n}=\mathbf{1}$ This community is similar to the Rough fescue-Hairy wildrye community type (SASMA3) previously described, but this type was described on a site with a north aspect . Corns and Achuff (1982), described hairy wildrye dominated community types on south facing slopes in the more northern ecodistricts. They felt these grasslands occurred on areas with frequent snow avalanching. It would appear that this community type represents the transition between the northerly hairy wildrye dominated grasslands and the southerly rough fescue-hairy wildrye dominated grasslands.

This community type was described in an area that is difficult for livestock to access. It should likely be rated as non-use.

\section{Plant Composition CANopy Cover(\%)} mean Range Const.

\section{SHRUBS}

SHRUBBY CINQUEFOIL.

(Potentilla fruticosa)

COMMON JUNIPER

(Juniperus communis)

$$
2
$$

100

100

\section{FORBS}

YELLOW BEARDTONGUE

(Penstemon confertus)

MISSOURI GOLDENROD

(Solidago missouriensis) $2 \quad-\quad 100$

FIREWEED

(Epilobium angustifolium)4 $\quad-\quad 100$

ALPINE HEDYSARUM

$\begin{array}{llll}\text { (Hedysarum alpinus) } & 5 & - & 100\end{array}$

MOUNTAIN DANDELION

(Agoseris glauca)

2

\section{GRASSES}

HAIRY WILDRYE

(Elymus innovatus) $\quad 20 \quad-\quad 100$

BLUNT SEDGE

(Carex obtusata)

ROUGH FESCUE

(Festuca scabrella)

$1 \quad-\quad 100$

$11 \quad-\quad 100$

\section{ENVIRONMENTAL VARIABLES}

MOISTURE REGIME:

SUBMESIC

NUTRIENT REGIME :

SUBMESOTROPHIC

ELEVATION:

$1951 \mathrm{M}$

SoIL DRAINAGE:

WELL

SLOPE:

$30 \%$

ASPECT:

NORTHERLY

ECOLOGICAL STATUS SCORE: 24

Forage Production Kg/HA

TOTAL 1225(900-1500)

ECOLOGICALLY SUSTAINABLE STOCKING RATE

$0.7(1-0.6) \mathrm{HA} / \mathrm{AUM}$ OR

$0.58(0.4-0.68) \mathrm{AUM} / \mathrm{AC}$ 


\section{SASMA4. Sedge-Hairy wildrye-Slender wheatgrass \\ (Carex obtusata-Elymus innovatus-Agropyron trachycaulum)}

$\mathbf{n = 1 1}$ This community type appears to result from moderate to heavy grazing pressure on a Rough fescue-Sedge dominated community type. Heavy grazing appears to cause rough fescue to decline and allows sedge to increase. Indeed Willoughby et al. (2005), described similar species composition changes with grazing on south facing slopes in the Montane subregion.

\section{Plant Composition Canopy Cover(\%)} Mean Range Const.

\section{SHRUBS}

SHRUBBY CINQUEFOIL

(Potentilla fruticosa)

4

$0-20$

64

\section{FORBS}

STRAWBERRY

WHITE CAMUS

$\begin{array}{llll}\text { (Zigadenus elegans) } & \text { T } & 0-1 & 9\end{array}$

YARROW
(Achillea millefolium) 7

SMOOTH LEAVED CINQUEFOIL

(Potentilla diversifolia) 8

BEARBERRY

(Arctostaphylos uva-ursi)2

YELLOW BEARDTONGUE

(Penstemon confertus)

OLD MAN'S WHISKERS

(Geum triflorum)

$1-15 \quad 100$

$0-23 \quad 64$

$0-18 \quad 18$

$0-25 \quad 45$

$0-11 \quad 64$

GraSSES

HAIRY WILDRYE

(Elymus innovatus)

ROUGH FESCUE

$\begin{array}{llll}\text { (Festuca scabrella) } & 5 & 0-24 & 73\end{array}$

SLENDER WHEATGRASS

(Agropyron trachycaulum)

IDAHO FESCUE

$\begin{array}{llll}\text { (Festuca idahoensis) } & 2 & 0-9 & 82\end{array}$

BLUNT SEDGE

(Carex obtusata)

$17 \quad 0-34 \quad 73$

\section{ENVIRONMENTAL VARIABLES}

MOISTURE REGIME:

SUBMESIC

NUTRIENT REGIME:

SUBMESOTROPHIC

ELEVATION:

$1410-1981(1638) \mathrm{M}$

SOIL DRAINAGE:

WELL

SLOPE:

$$
0-35(12) \%
$$

ASPECT:

SOUTHERLY

ECOLOGICAL STATUS SCORE: 16

\section{Forage Production Kg/Ha}

$$
\begin{array}{ll}
\text { GRASS } & 1116(516-1364) \\
\text { FORB } & 683(140-1042) \\
\text { SHRUB } & 56(0-408) \\
\text { TOTAL } & 1891(1404-2318)
\end{array}
$$

ECOLOGICALLY SUSTAINABLE STOCKING RATE $0.8(1.0-0.7)$ HA/AUM OR $0.5(0.4-0.57) \mathrm{AUM} / \mathrm{AC}$ 


\section{SASMA6. Yellow mountain avens \\ (Dryas drummondii)}

$\mathbf{n}=\mathbf{1}$ This is similar to the community type described in the Central and Northern Rocky Mountain ecodistricts. Corns and Achuff (1982) described this community type on recent fluvial and glacialfluvial landforms with gentle slopes, where the soils are rapidly drained. Willoughby et al. (2005), described a yellow mountain avens community on dry, gravelly river flats with nutrient poor soils in the Montane subregion. They found this community type to be successionally immature and succession would be to a Balsam poplar dominated community type.

\section{Plant COMPOSITION CANOPY COVER(\%)} Mean Range Const.

\section{SHRUBS}

SHRUBBY CINQUEFOIL

(Potentilla fruticosa)

$4 \quad-\quad 100$

FORBS

YELLOW DRYAD

(Dryas drummondii) $\quad 13 \quad-\quad 100$

LATE YELLOW LOCOWEED

(Oxytropis monticola) 5

SILVERY CINQUEFOIL

$\begin{array}{llll}\text { (Potentilla argentea) } & 3 & - & 100\end{array}$

LOW GOLDENROD

(Solidago missouriensis) $3 \quad-\quad 100$

YELLOW HEDYSARUM

(Hedysarum sulphurscens)3

Grasses

HAIRY WILDRYE

(Elymus innovatus)

JUNEGRASS

(Koeleria macrantha)

SLENDER WHEATGRASS

(Agropyron trachycaulum) 1

BLUNT SEDGE

(Carex obtusata)

FRINGED BROME

(Bromus ciliatus)

100

100

100

100

100
MOISTURE REGIME:

MESIC

NUTRIENT REGIME:

SUBMESOTROPHIC

ELEVATION:

$2165 \mathrm{M}$

SOIL DRAINAGE:

WELL TO RAPIDLY

ECOLOGICAL STATUS SCORE: 24

Forage Production Kg/HA

GRASS 572

FORB 602

TOTAL $1372 *$ ESTIMATE
ECOLOGICALLY SUSTAINABLE STOCKING RATE GENERALLY NON-USE 40(40-8.5) HA/AUM or .01(.01-.04) AUM/AC 


\section{SASMA7. Tufted hairgrass-Sedge \\ (Deschampsia cespitosa-Carex spp.)}

$\mathbf{n}=\mathbf{3}$ This community type was described in the Savanna Creek range allotment and is located on moist sites that are better drained and slightly drier than the pure sedge meadows. Willoughby(2005), found that tufted hairgrass is a common plant species on lowland sites in the valley bottoms of the Upper Foothills subregion . Willoughby (1992), found when this community type is protected from grazing for 25-30 years, willow and bog birch expand and tufted hairgrass and sedge decline. The decline in graminoid cover also results in a decline in available forage production. Continuous heavy grazing causes hairgrass to decline and the site will be invaded by Kentucky bluegrass and dandelion.

Plant Composition Canopy Cover(\%)

\section{Mean Range Const.}

SHRUBS

BARCLAY'S WILLOW

(Salix barclayi)

SHRUBBY CINQUEFOIL

(Potentilla fruticosa)

$\begin{array}{lll}3 & 0-7 & 33 \\ 1 & 0-2 & 33\end{array}$

\section{FORBS}

LINDLEY'S ASTER

(Aster ciliolatus)

YELLOW HEDYSARUM

(Hedysarum sulphurscens)1

YARROW

(Achillea millefolium)

GRACEFUL CINQUEFOIL

(Potentilla gracilis)

OLD MAN'S WHISKERS

(Geum triflorum)

AMERICAN VETCH

(Vicia americana)

Grasses

TWO-SEEDED SEDGE

(Carex disperma)

TUFTED HAIRGRASS

(Deschampsia cespitosa) 41

SLENDER WHEATGRASS

(Agropyron trachycaulum)2 $\quad 1-4 \quad 100$

ROUGH FESCUE

(Festuca scabrella)

HAIRY WILDRYE

(Elymus innovatus)
14

$1 \quad 0-2 \quad 33$

$0-3 \quad 33$

$3-10 \quad 100$

6-14 100

$0-9 \quad 68$

$0-1 \quad 67$

$18-62 \quad 100$

$0-6 \quad 33$

$6 \quad 0-18 \quad 33$

\section{ENVIRONMENTAL VARIABLES}

MOISTURE REGIME:

SUBHYGRIC

NUTRIENT REGIME:

PERMESOTROPHIC

ELEVATION:

1445(1445-1450)M

SOIL DRAINAGE： MOD. WELL

SLPOE $4 \%$

ASPECT:NORTHERLY

ECOLOGICAL STATUS SCORE: 24

Forage Production KG/HA

GRASS 1164

FORBS $\quad 162$

SHRUBS 0

TOTAL $\quad 1326$

ECOLOGICALLY SUSTAINABLE STOCKING RATE

$0.8(1.2-0.7) \mathrm{HA} / \mathrm{AUM} \mathrm{OR}$

$0.5(.33-.57) \mathrm{AUM} / \mathrm{AC}$ 


\section{SASMA7a. Marsh reedgrass/Cow parsnip (Calamagrostis canadensis/Heracleum lanatum.)}

$\mathbf{n}=\mathbf{1}$ This community type represents moist seepage areas in the foothills west of Turner valley. Often these sites are willow dominated to form the Willow/Marsh reedgrass dominated community type. Marsh reedgrass is characteristic of the lower elevation Lower Foothills subregion. Moving up in elevation into the Subalpine and Upper Foothills subregions, there is often a shift in dominance away from marsh reedgrass to tufted hairgrass on these moist sites. This community type is very similar to the Cow parsnip/Veiny meadow rue community described by Lawrence et al. (2005) in the Lower Foothills subregion. In the Lower Foothills this community type is very productive and is often heavily utilized by livestock. The Marsh reedgrass-Timothy/Cow parsnip (SASMC8) represents a grazing disclimax of this community type.

PLANT COMPOSITION CANOPY COVER(\%)

\section{SHRUBS}

PRICKLY ROSE

(Rosa acicularis)

RASPBERRY

(Rubus idaeus)

4

1

Mean Range Const.

\section{FORBS}

COW PARSNIP

(Heracleum lanatum) $3 \quad$ - $\quad 100$

FIREWEED

(Epilobium angustifolium) 25

WESTERN MEADOW RUE

(Thalictrum occidentalis) 10

HORSETAIL

(Equisetum arvense) 4

STICKY PURPLE GERANIUM

(Geranium viscosissimum)4

AMERICAN VETCH

(Vicia americana)

2

$-100$

$-100$

$-\quad 100$

$-100$

\section{GRASSES}

SEDGE

(Carex spp)

MARSH REEDGRASS

(Calamagrostis canadensis)24 - 100

SLENDER WHEATGRASS

(Agropyron trachycaulum)1 - 100

IDAHO FESCUE

(Festuca idahoensis)
100

100

100

100

00

00

100

100

100

\section{ENVIRONMENTAL VARIABLES}

MOISTURE REGIME:

SUBHYGRIC

NUTRIENT REGIME:

PERMESOTROPHIC

ELEVATION:

$1768 \mathrm{M}$

SOIL DRAINAGE： MOD. WELL

SLOPE $3 \%$

ASPECT: SOUTHERLY

ECOLOGICAL STATUS SCORE: 24

Forage Production Kg/HA

TOTAL 2000* ESTIMATE

ECOLOGICALLY SUSTAINABLE STOCKING RATE $0.8(0.9-0.5) \mathrm{HA} / \mathrm{AUM}$ OR $0.5(.45-0.8)$ HA/AUM 


\section{SASMA8. Rough fescue-Idaho fescue-Parry oatgrass \\ (Festuca scabrella-Festuca idahoensis-Danthonia parryii)}

$\mathbf{n}=\mathbf{4}$ This community was described on lower slope positions in the Castle area. It is very similar to the Rough fescue-Idaho fescue-Parry oatgrass community described on Black Chernozemic soils in the Montane subregion from an elevation of $1300 \mathrm{~m}$ up to $1900 \mathrm{~m}$ (Willoughby et al. 2005) Willoughby (1992), described one Rough fescue-dominated site where the species composition had not changed in over 30 years, indicating this maybe the climax community type on river terraces and south facing slopes in the Montane subregion. Indeed Moss and Campbell (1947), found that rough fescue grows almost to the exclusion of other plants in the absence of disturbance. On rocky and gravelly slopes with shallow soils, rough fescue is replaced by Parry oatgrass and Idaho fescue. They also found Parry oatgrass and Idaho fescue increased and rough fescue declined with increased grazing pressure. Willoughby (1992), also described rough fescue and Idaho fescue dominated community types with little Parry oatgrass in the Castle area south of Blairmore. He also found that rose and shrubby cinquefoil tended to increase in cover at higher elevations in these grasslands.

\section{Plant Composition Canopy Cover(\%) Mean Range Const.}

SHRUBS

SHRUBBY CINQUEFOIL

(Potentilla fruticosa)

PRICKLY ROSE

(Rosa acicularis)

$4 \quad 1-10 \quad 100$

$\begin{array}{lll}3 & 0-8 & 75\end{array}$

FORBS

SHOWY ASTER

(Aster conspicuus)

COMMON FIREWEED

(Epilobium angustifolium) 4

CUT-LEAVED ANEMONE

(Anemone multifida)

GRACEFUl CINQUEFOIL

(Potentilla gracilis)

LONG-FRUITED WILD PARSLEY

(Lomatium macrocarpum) 1

LOW GOLDENROD

(Solidago missouriensis) 2

Grasses

ROUGH FESCUE

(Festuca scabrella)

IDAHO FESCUE

(Festuca idahoensis)

PARRY OATGRASS

(Danthonia parryi)

PINE REED GRASS

(Calamagrostis rubescens)4

HAIRY WILDRYE

(Elymus innovatus)
$0-12 \quad 50$

$0-15 \quad 50$

$0-1 \quad 50$

\section{ENVIRONMENTAL VARIABLES}

MOISTURE REGIME:

SUBXERIC TO SUBMESIC

NUTRIENT REGIME:

SUBMESOTROPHIC TO MESOTROPHIC

ELEVATION:

$$
\text { 1838(1680-1974) M }
$$

SOIL DRAINAGE:

VERY RAPIDLY TO WELL

SLOPE: $13(6-22) \%$

ASPECT: VARIABLE

ECOLOGICAL STATUS SCORE: 24

Forage Production KG/HA

GRASS 1146(934-1358)

FORBS 614(488-740)

SHRUBS 55(0-109)

TотAL 1815(1674-1955)

ECOLOGICALLY SUSTAINABLE STOCKING RATE

$0.5(0.55-0.45) \mathrm{HA} / \mathrm{AUM}$ or

$0.81(0.73-0.9) \mathrm{AUM} / \mathrm{AC}$ 


\section{SASMA9. Rough fescue-Sedge/Bearberry \\ (Festuca scabrella-Carex obtusaia./Arctostaphylos uva-ursi)}

$\mathbf{n = 1 4}$ This community is characteristic of dry, south facing slopes, below the crest of the hill. It appears that snow accumulates in these areas favoring the growth of rough fescue. This community is similar to the Rough fescueSedge/Bearberry community type described by Willoughby et al. (2005) on hilltops in the Montane subregion. The shallow poorly developed soils appear to favour rough fescue, slender wheatgrass, and sedge over Parry oatgrass. This community is drier than the Rough fescue-Idaho fescue-Parry oatgrass grasslands characteristic of lower slope positions. This community type is similar to the Sedge/Bearberry community type but lacks the high cover of rough fescue. It appears that the Sedge/Bearberry community may represent a grazing disclimax of this community type.

\section{Plant Composition Canopy Cover(\%)} Mean Range Const.

\section{SHRUBS}

SHRUBBY CINQUEFOIL

$\begin{array}{llll}\begin{array}{l}\text { (Potentilla fruticosa) } \\ \text { PRICKLY ROSE }\end{array} & 4 & 0-11 & 93 \\ \text { (Rosa acicularis) } & 1 & 0-6 & 43\end{array}$

\section{FORBS}

BEARBERRY

(Arctostaphylos uva-ursi)29

SILKY PERENNIAL LUPINE

(Lupinus sericeus)
CUT-LEAVED ANEMONE
(Anemone multifida)

WILD STRAWBERRY

(Fragaria virginiana)

SMOOTH ASTER

(Aster laevis)

LOW GOLDENROD

(Solidago missouriensis)

$2 \quad 0-10 \quad 43$

$2 \quad 0-2 \quad 79$

$1 \quad 0-9 \quad 43$

$1 \quad 0-8 \quad 21$

$0-6 \quad 50$

\section{GRASSES}

ROUGH FESCUE

(Festuca scabrella)

SEDGES

(Carexspp.)

PARRY OATGRASS

(Danthonia Perryi)

JUNEGRASS

(Koeleria macrantha) $\quad 1 \quad 0-15 \quad 64$

HAIRY WILDRYE

(Elymus innovatus)
$19 \quad 6-43 \quad 100$

$2 \quad 0-5 \quad 71$

$1 \quad 0-18 \quad 21$

$2-0-90$

\section{ENVIRONMENTAL VARIABLES}

MOISTURE REGIME:

XERIC TO MESIC

NUTRIENT REGIME:

OLIGOTROPHIC TO MESOTROPHIC

ELEVATION:

1811(1400-2115)M

SOIL DRAINAGE:

VERY RAPIDLY-WELL

SLOPE:

$34(18-70) \%$

ASPECT:

VARIABLE

ECOLOGICAL STATUS SCORE: 24

Forage Production Kg/Ha
ECOLOGICALLY SUSTAINABLE STOCKING RATE $1.5(1.5-0.5) \mathrm{HA} / \mathrm{AUM}$ OR $0.28(0.28-0.8)$ AUM/AC
GRASS 695(102-1612)

FORB 285(111-676)

SHRUB $680(28-4400)$

TOTAL 1542(970-5384) 


\section{SASMA10. Parry oatgrass-Rough fescue-Sedge (Danthonia parryi-Festuca scabrella-Carex spp)}

$\mathbf{n = 1 2}$ This community is situated upslope of the rough fescue dominated community types. This community type tends to be drier and better drained than the rough fescue dominated types found in the lower slope positions. The drier site conditions favour the growth of Parry oatgrass and sedge over rough fescue.

These sites are moderately productive and are easily accessible to livestock. They should be considered primary range. Continuous heavy grazing pressure will lead to a community type that is dominated by sedge and fringed sage.

\section{Plant Composition Canopy Cover(\%)} Mean Range Const.

\section{SHRUBS}

SHRUBBY CINQUEFOIL

$\begin{array}{llll}\begin{array}{l}\text { (Potentilla fruticosa) } \\ \text { PRICKLY ROSE }\end{array} & 4 & 0-10 & 92 \\ \begin{array}{l}\text { (Rosa acicularis) } \\ \begin{array}{l}\text { SASKATOON } \\ \text { (Amelanchier alnifolia) }\end{array}\end{array} & 2 & 0-5 & 75 \\ \end{array}$

\section{FORBS}

SILKY PERENNIAL LUPINE

\begin{tabular}{|c|c|c|}
\hline (Lupinus sericeus) & 5 & $0-18$ \\
\hline CUT-LEAVED ANEMONE & & \\
\hline $\begin{array}{l}\text { (Anemone multifida) } \\
\text { OLD MAN'S WHISKERS }\end{array}$ & 2 & $0-2$ \\
\hline (Geum triflorum) & 2 & $0-21$ \\
\hline $\begin{array}{l}\text { NORTHERN BEDSTRAW } \\
\text { (Galium boreale) }\end{array}$ & 4 & $1-8$ \\
\hline EARLY YELLOW LOCOWEE & & \\
\hline $\begin{array}{l}\text { (Oxytropis sericea) } \\
\text { GOLDENBEAN }\end{array}$ & 2 & $0-6$ \\
\hline (Thermophis rhombifolia & & $0-8$ \\
\hline
\end{tabular}

Grasses

ROUGH FESCUE

\begin{tabular}{|c|c|c|c|}
\hline (Festuca scabrella) & 6 & $0-15$ & 92 \\
\hline PARRY OATGRASS & & & \\
\hline (Danthonia parryi) & 23 & $10-31$ & 100 \\
\hline SEDGES & & & \\
\hline (Carex spp.) & 3 & $0-8$ & 94 \\
\hline JUNE GRASS & & & \\
\hline (Koeleria macrantha) & 3 & $0-6$ & 92 \\
\hline COLUMBIA NEEDLE GRASS & & & \\
\hline (Stipa columbiana) & 5 & $0-13$ & 75 \\
\hline SLENDER WHEATGRASS & & & \\
\hline (Agropyron trachycaulv & & $0-5$ & 75 \\
\hline
\end{tabular}

\section{ENVIRONMENTAL VARIABLES}

MOISTURE REGIME:

XERIC TO SUBXERIC

NUTRIENT REGIME :

OLIGOTROPHIC TO PERMESOTROPHIC

ELEVATION:

1473(1400-1962) M

SOIL DRAINAGE:

RAPIDLY TO WELL

SLOPE:

$$
23(12-33) \%
$$

ASPECT:

VARIABLE

ECOLOGICAL STATUS SCORE: 24

\section{Forage Production Kg/HA}

$$
\begin{array}{ll}
\text { GRASS } & 732(356-1284) \\
\text { FORB } & 702(0-1550) \\
\text { SHRUB } & 96(0-388) \\
\text { TOTAL } & 1452(660-2866)
\end{array}
$$

ECOLOGICALLY SUSTAINABLE STOCKING RATE $0.6(1.4-0.6) \mathrm{HA} / \mathrm{AUM}$ OR $0.57(0.29-0.67) \mathrm{AUM} / \mathrm{AC}$ 


\section{SASMA11. Sedge/Bearberry \\ (Carex spp./Arctostaphylos uva-ursi)}

$\mathbf{n = 1 1}$ This community was described on south facing slopes. This community is very similar to the Rough fescue-Sedge/Bearberry community type, but lacks the high cover of rough fescue. A number of the sites described in this community had extensive grazing pressure by bighorn sheep and domestic livestock. It is possible that this community type represents a grazing disclimax of the Rough fescue-Sedge/Bearberry community type.

\section{Plant COMPOSITION CANOPY COVER(\%)} mean Range Const.

\section{TREES}

SUBALPINE FIR

(Abies lasiocarpa)

WHITE BARK PINE

(Pinus albicaulis)

$\begin{array}{lll}\text { T } & 0-2 & 20 \\ \text { T } & 0-3 & 20\end{array}$

\section{SHRUBS}

BEARBERRY

\section{(Arctostaphylos uva-ursi) 27}

SHRUBBY CINQUEFOIL

$\begin{array}{llll}\text { (Potentilla fruticosa) } \quad 2 & 0-8 \quad 70\end{array}$

SASKATOON

(Amelanchier alnifolia)

\section{FORBS}

EARLY YELLOW LOCOWEED

(Oxytropis sericea) $2 \quad 0-5 \quad 90$

BROWN-BRACTED MOUNTAIN EVERLASTING

$\begin{array}{llll}\begin{array}{l}\text { (Antennaria umbrinella) } \\ \text { YELLOW VALSE DANDELION }\end{array} & 0-5 & 50 \\ \begin{array}{l}\text { (Agoseris glauca) } \\ \text { ARCTIC SANDWORT }\end{array} & 1 & 0-3 & 70 \\ \begin{array}{l}\text { (Minuartia obtusiloba) } \\ \text { YELLOW HEDYSARUM }\end{array} & 1 & 0-3 & 40 \\ \begin{array}{l}\text { (Hedysarum sulphurescens)2 } \\ \text { COMMON FIREWEED } \\ \text { (Epilobium angustifolium)1 }\end{array} & 0-6 & 60 \\ \end{array}$

Grasses

SEDGES

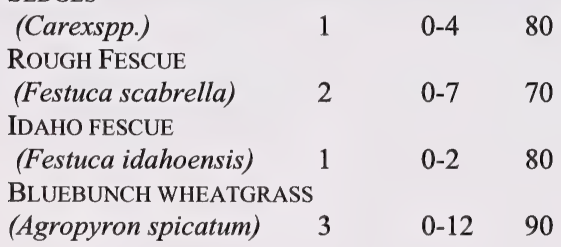

\section{ENVIRONMENTAL VARIABLES}

MOISTURE REGIME:

XERIC-SUBXERIC

NUTRIENT REGIME:

OLIGOTROPHIC TO PERMESOTROPHIC

ELEVATION:

1883(1706-2072)M

SOIL DRAINAGE:

VERY RAPIDLY TO WELL

SLOPE: $31(16-50) \%$

ASPECT: SOUTH TO WEST

ECOLOGICAL STATUS SCORE: 16
ECOLOGICALLY SUSTAINABLE STOCKING RATE

$$
\begin{aligned}
& \text { GENERALLY NON-USE } \\
& 1.7(1.7-0.5) \mathrm{HA} / \mathrm{AUM} \text { OR } \\
& 0.23(0.23-0.8) \mathrm{AUM} / \mathrm{AC}
\end{aligned}
$$




\section{SASMA12. Silverberry-Rose \\ (Elaeagnus commutata-Rosa acicularis)}

$\mathbf{n}=\mathbf{1}$ This community type was described on the downwind side of the hill at lower elevations in the Castle area of the province (north of Waterton Lakes National Park). It appears this area accumulates snow so the moisture regime is favorable for the growth of silverberry and aspen. At $1800 \mathrm{~m}$ aspen is at its upper elevational limit. The aspen trees at this site are very stunted and lack the vigour of lower elevation sites. Silverberry is well adapted to growing on dry, gravelly, light soils in ravines, coulees and stream banks throughout Alberta (Wilkinson 1990). It is unusual to have silverberry and aspen growing at these higher elevations indicating that this site is somewhat protected and warmer so that the climate resembles the lower elevation sites.

\section{Plant COMPOSITION CANOPY COVER(\%)} Mean Range Const.

\section{TREES}

ASPEN

(Populus tremuloides)

4

100

SHRUBS

SILVERBERRY

(Elaeagnus commutata) $15 \quad-\quad 100$

PRICKLY ROSE

(Rosa acicularis)

5

ASPEN

(Populus tremuloides)

\section{FORBS}

MOUSE EARED CHICKWEED

(Cerastium arvense)

FALSE DANDELION

(Agoseris glauca)

SILVER PLANT

(Eriogonum ovalifolium) T

\section{GRASSES}

ROCKY MOUNTAIN FESCUE

(Festuca brachycaulum) 1

BLUEBUNCH WHEATGRASS

(Agropyron spicatum) 3

\section{ENVIRONMENTAL VARIABLES}

MOISTURE REGIME:

XERIC

NUTRIENT REGIME:

SUBMESOTROPHIC

ELEVATION: $\quad 1841 \mathrm{M}$

SOIL DRAINAGE: VERY RAPIDLY

SLOPE: $24 \%$

ASPECT: SOUTHEASTERLY

ECOLOGICAL STATUS SCORE: 24

Forage Production KG/HA

Total $\quad 500 *$ Estimate

ECOLOGICALLY SUSTAINABLE STOCKING RATE

1.8(1.8-1.0) HA/AUM OR

$0.22(0.22-0.4)$ AUM/AC 


\section{SASMA13. Fescue-Junegrass/Early yellow locoweed (Festuca spp.-Koeleria macrantha/Oxytropis sericea)}

$\mathbf{n = 1 7}$ This community type is characteristic of the dry, rocky, windswept ridges in the Castle area north of Waterton Lakes National Park. At higher elevations this community is often replaced by the White mountian avens community which occupies similar sites. This community type is somewhat variable false mountain dandelion and early yellow locoweed were found in the majority of the plots, but in areas where there is slightly more snow accumulation the cover of Idaho fescue increases, and there are larger patches of species like spotted saxifrage, brown bracted mountian everlasting and sandwort. Bareground on these moister areas is usually less than $40 \%$. In contrast bareground on the drier parts of this community type exceed $60 \%$. At lower elevations on Whistler Mtn. bluebunch wheatgrass becomes more prevalent.

\section{Plant Composition CANOPY Cover(\%)} Mean Range CONST.

\section{SHRUBS}

SHRUBBY CINQUEFOIL

\section{(Potentilla fruticosa)}

LIMBER PINE

(Pinus flexilis)

$\begin{array}{lll}3 & 0-13 & 82 \\ 1 & 0-11 & 12\end{array}$

\section{FORBS}

BEARBERRY

\begin{tabular}{|c|c|c|}
\hline (Arctostaphylos uva-ursi) & & $0-8$ \\
\hline $\begin{array}{l}\text { KITTENTAILS } \\
\text { (Besseya wyomingensis) }\end{array}$ & 1 & $0-3$ \\
\hline EARLY YELLOW LOCOWEE & & \\
\hline (Oxytropis sericea) & 1 & $0-5$ \\
\hline SANDWORT & & \\
\hline (Minuartia obtusiloba) & 3 & $0-16$ \\
\hline LITTLE CLUBMOSS & & \\
\hline (Selaginella densa) & 2 & $0-8$ \\
\hline $\begin{array}{l}\text { SPOTTED SAXIFRAGE } \\
\text { (Saxifraga bronchialis) }\end{array}$ & 3 & $0-29$ \\
\hline
\end{tabular}

\section{GRASSES}

ROUGH FESCUE

(Festuca scabrella) $\quad 1 \quad 0-6 \quad 24$

JUNEGRASS

(Koeleria macrantha) $\quad 2 \quad 0-5 \quad 77$

SEDGE

(Carex spp.)

IDAHO FESCUE

(Festuca idahoensis) $\quad 3 \quad 0-20 \quad 41$

SMOOTH BROME

(Bromus pumpellianus) $1 \quad 0-5 \quad 53$

BLUEBUNCH WHEATGRASS

(Agropyron spicatum)

\section{ENVIRONMENTAL VARIABLES}

MOISTURE REGIME:

VERY XERIC TO SUBXERIC

NUTRIENT REGIME:

OLIGOTROPHIC TO MESOTROPHIC

ELEVATION:

1949(1536-2322) M

SOIL DRAINAGE:

VERY RAPIDLY TO WELL

SLOPE: $26(6-50) \%$

ASPECT: VARIABLE

ECOLOGICAL STATUS SCORE: 24

\section{Forage Production Kg/HA}

ECOLOGICALLY SUSTAINABLE STOCKING RATE GENERALLY NON-USE $2.0(2.0-1.0)$ HAVAUM $0.2(0.2-0.4) \mathrm{AUM} / \mathrm{AC}$ 


\section{SASMA14. White mountain avens \\ (Dryas octopetala)}

$\mathbf{n = 1 2}$ This community occurs on wind-exposed, snow free ridges and resembles the White mountain avens community described in the Alpine subregion. The soils are shallow, stoney, colluvial Regosols (Corns and Achuff 1982). Ogilvie (1969), found this community type to have an abundance of cushion and mat plants and a large number of lichens. This community is generally found at higher elevations than the Fescue-Junegrass/E. yellow locoweed community type. This community type appears to have no snow accumulation throughout the year, whereas, the fescue, Junegrass dominated community appears to have some snow accumulation. This may account for the differences in dominant plant species for each community type.

\section{Plant Composition Canopy Cover(\%)} Mean Range Const.

\section{SHRUBS}

PRICKLY ROSE

(Rosa acicularis)

SHRUBBY CINQUEFOIL

(Potentilla fruticosa) $2 \quad 0-6 \quad 92$

BUFFALOBERRY

$\begin{array}{llll}\text { (Shepherdia canadensis) } & \text { T } & 0-3 & 8\end{array}$

SILVERBERRY

(Elaeagnus commutata)

$\mathrm{T}$

FORBS

WHITE MOUNTAIN AVENS

(Dryas octopetala) 3

EARLY YELLOW LOCOWEED

(Oxytropis sericea) 3

SPOTTED SAXIFRAGE

(Saxifraga bronchialis)

KITTENTAILS

(Besseya wyomingensis) 1

YELLOW HEDYSARUM

(Hedysarum sulphurscens)2

FALSE MTN. DANDELION

(Agoseris glauca)

1

\section{GRASSES}

IDAHO FESCUE

(Festuca idahoensis) $\quad 1 \quad 0-4 \quad 33$

SEDGE SPP.

(Carex spp.)

SMOOTH BROME

(Bromus pumpellianus)

(Koeleria macrantha)
$1 \quad 14-48 \quad 100$

$1-7 \quad 100$

$0-7 \quad 42$

$0-2 \quad 83$

0-4 67

$0-2 \quad 83$

\section{ENVIRONMENTAL VARIABLES}

MOISTURE REGIME:

VERY XERIC-SUBXERIC

NUTRIENT REGIME:

OLIGOTROPHIC TO SUBMESOTROPHIC

ELEVATION:

$$
\text { 2136(2001-2423) M }
$$

SOIL DRAINAGE:

VERY RAPIDLY TO RAPIDLY

SLOPE : $17(7-38) \%$

ASPECT: VARIABLE

ECOLOGICAL STATUS SCORE: 24

\section{Forage Production Kg/HA}

$$
\begin{array}{ll}
\text { GRASS } & 36(25-47) \\
\text { FORB } & 198(27-369) \\
\text { SHRUB } & 392(195-589) \\
\text { TOTAL } & 626(269-983)
\end{array}
$$

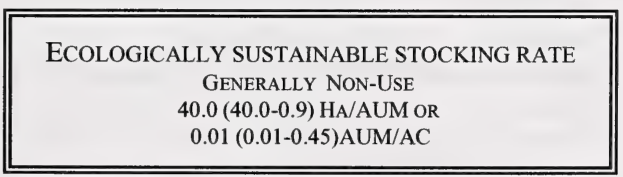




\section{SASMA15. Pinegrass-Hairy wildrye/Strawberry (Calamagrostis rubescens-Elymus innovatus/Fragaria virginiana)}

$\mathbf{n}=\mathbf{4}$ This community type is similar to the pinegrass dominated community type described on west and north facing slopes in the Montane subregion (Willoughby et al 2005). In the Montane this community represents the transition from grassland to forest on moist sites with northerly aspects. There is usually high forb cover on these sites with strawberry, showy aster, american vetch and silkly perennial lupine being common. Pinegrass and Hairy wildrye are common grass species in the understory of conifer and deciduous stands and their dominance in this community type may indicate a transition to a forested community. The higher moisture conditions on these sites allows for production of over $2000 \mathrm{~kg} / \mathrm{ha}$.

\section{Plant Composition Canopy Cover(\%)}

\section{SHRUBS}

PRICKLY ROSE

(Rosa acicularis)

Mean Range Const.

SHRUBBY CINQUEFOIL

(Potentilla fruticosa)

WHITE MEADOWSWEET

(Spiraea betulifolia) $1 \quad 0-4 \quad 25$

ASPEN

(Populus tremuloides)

\section{FORBS}

SILKY PERENNIAL LUPINE

(Lupinus sericeus)

SHOWY ASTER

(Aster conspicuus)

COMMON DANDELION

(Taraxacum officinale) 3

CREAM-COLORED VETCHILING

(Lathyrus ochroleucus) 2

GRACEFUL CINQUEFOIL

(Potentilla gracilis)
FALSE MTN. DANDELION

(Agoseris glauca)

1

\section{GRASSES}

PINEGRASS

$\begin{array}{lll}\text { (Calamagrostis rubescens) } 11 & 1-22 & 100 \\ \text { JUNEGRASS }\end{array}$

(Koeleria macrantha) $2 \quad 1-2 \quad 100$

HAIRY WILDRYE

(Elymus innovatus) $\quad 4 \quad 0-11 \quad 75$

KENTUCKY BLUEGRASS

(Poa pratensis)
$1-20 \quad 100$

$1-2 \quad 100$

$0-3 \quad 50$

$1-7 \quad 100$

$1-6 \quad 100$

$1-8 \quad 100$

$1-3 \quad 100$

$1-2 \quad 100$

$0 \quad 100$

\section{ENVIRONMENTAL VARIABLES}

MOISTURE REGIME:

SUBXERIC TO MESIC

NUTRIENT REGIME:

SUBMESOTROPHIC TO MESOTROPHIC

ELEVATION:

1701(1684-1710)M

SOIL DRAINAGE:

WELL TO IMPERFECTLY

SLOPE (RANGE):

$$
31(23-40) \%
$$

ASPECT:

SOUTHERLY

ECOLOGICAL STATUS SCORE: 24

Forage Production KG/HA

GRASS 758(392-1204)

FORB 1170(506-1884)

SHRUB $110(0-260)$

TotAL 2037(1346-2739)

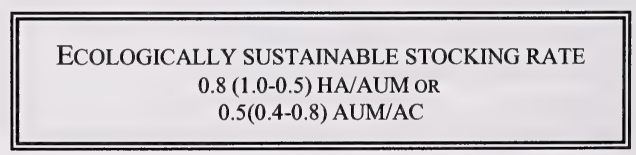




\section{SASMA16. Forb meadow \\ (Epilobium angustifolium)}

$\mathbf{n}=\mathbf{3}$ This site is similar to the Fireweed-Meadow rue/Sedge dominated community type described in the northern foothills area of the Subalpine. This community is characterized by a dominance of forb species (fireweed, graceful cinquefoil, yellow hedysarum) and only a small cover of grass species. It would appear that the moisture and nutrient regime are higher on this site compared to the other grassland community types which favors the growth of forb species. Succession in the absence of disturbance will likely be to aspen and then white spruce.

The forage production of this community type is fairly high because of the higher moisture and nutrient content of the soil, but the areas are so small and isolated they contribute little to the overall carrying capacity of a disposition.

\section{PLANT COMPOSITION CANOPY COVER(\%) Mean Range Const.}

\section{SHRUBS}

PRICKLY ROSE

(Rosa acicularis)

SHRUBBY CINQUEFOIL

(Potentilla fruticosa) $\quad 3 \quad 1-5 \quad 100$

CREEPING JUNIPER

(Juniperus horizontalis)

\section{FORBS}

GRACEFUL CINQUEFOIL

(Potentilla gracilis)

COMMON FIREWEED

(Epilobium angustifolium)6

YELLOWHEDYSARUM

(Hedysarum sulphurescens)4 $1-9 \quad 100$

WILD VETCH

(Vicia americana)

WILD STRAWBERRY

(Fragaria virginiana)

CUT-LEAVED ANEMONE

(Anemone multifida)

GraSSES

HAIRY WILDRYE

(Elymus innovatus)

PARRYS OATGRASS

(Danthonia parryi)

TIMOTHY

(Phleum pratense)

ROUGH FESCUE

(Festuca scabrella)

$3 \quad 1-6 \quad 100$

$\begin{array}{lll}2 & 1-2 & 100 \\ 3 & 1-5 & 100 \\ 1 & 0-2 & 67\end{array}$

$2-10 \quad 100$

$1-3 \quad 100$

$1-2 \quad 100$

$1-2 \quad 100$

$1 \quad 1-2 \quad 100$

$3 \quad 1-5 \quad 100$

$2 \quad 1-3 \quad 100$

$1 \quad 0-1 \quad 67$

$2 \quad 0-4 \quad 33$

\section{ENVIRONMENTAL VARIABLES}

MOISTURE REGIME:

MESIC

NUTRIENT REGIME:

PERMESOTROPHIC TO MESOTROPHIC

ELEVATION: 1701(1684-1710)

SOIL DRAINAGE:

WELL TO IMPERFECTLY

SLOPE: $3(0-7) \%$

ASPECT: VARIABLE

ECOLOGICAL STATUS SCORE: 24

\section{Forage Production Kg/HA}

$\begin{array}{ll}\text { GRASS } & 554(175-1126) \\ \text { FORB } & 734(567-1009) \\ \text { SHRUB } & 125(0-208) \\ \text { TOTAL } & 1413(968-2135)\end{array}$

ECOLOGICALLY SUSTAINABLE STOCKING RATE $0.6(1.0-0.6) \mathrm{HA} / \mathrm{AUMM}$ OR 0.68 (0.4-0.67) AUM/AC 


\section{SASMA17. Bluebunch wheatgrass-Sedge \\ (Agropyron spicatum-Carex obtusata)}

$\mathbf{n}=1$ Bluebunch wheatgrass dominated sites are found on well-drained, south facing-slopes in the Montane subregion throughout southern Alberta (Strong 1992). In the Subalpine this community type is found on steep, isolated south facing slopes which have a Montane like microclimate. Increased grazing pressure on the drier sites leads to a decline in bluebunch wheatgrass and allows low growing forbs and sedge species to increase. Forage production on this type can vary from $700 \mathrm{~kg} / \mathrm{ha}$ on dry sites to over $1600 \mathrm{~kg} / \mathrm{ha}$ on moister sites.

\section{Plant Composition Canopy Cover(\%)} Mean Range Const.

\section{SHRUBS}

SHRUBBY CINQUEFOIL

(Potentilla fruticosa) $\quad 3 \quad-\quad 100$

FRINGED SAGE

(Artemisia frigida)

6

100

\section{FORBS}

STRAWBERRY

(Fragaria virginiana)

YARROW

(Achillea millefolium)

EARLY YELLOW LOCOWEED

(Oxytropis sericea)

\section{GRASSES}

JUNEGRASS

(Koeleria macrantha) $\quad 9 \quad-\quad 100$

BLUNT SEDGE

(Carex obtusata) $\quad 3 \quad-\quad 100$

BLUEBUNCH WHEATGRASS

$\begin{array}{llll}\text { (Agropyron spicatum) } & 15 \quad-\quad 100\end{array}$

ROUGH FESCUE

$\begin{array}{lll}\text { (Festuca scabrella) } & 7 & -\end{array}$
SOIL DRAINAGE:

VERY RAPIDLY

SLOPE： $31-45 \%$

ASPECT: SOUTHERLY

ECOLOGICAL STATUS SCORE: 24

\section{Forage Production Kg/Ha}

GRASS 600

FORB 350

SHRUB 200

TOTAL 1150

ECOLOGICALLY SUSTAINABLE STOCKING RATE $2(3.5-0.75)) \mathrm{HA} / \mathrm{AUM}$ OR $0.2(0.11-.54)) \mathrm{AUM} / \mathrm{AC}$

\section{ENVIRONMENTAL VARIABLES}

\section{MOISTURE REGIME:}

XERIC-SUBMESIC

NUTRIENT REGIME:

SUBMESOTROPHIC TO MESOTROPHIC

ELEVATION: $1725 \mathrm{M}$ 


\section{SASMB1. Willow/Sedge \\ (Salix spp./Carex spp.)}

$\mathbf{n}=\mathbf{6}$ Willow encroachment into moist grassland meadows eventually results in this community type. Historically fire has played an important role in the maintenance of the grassland community type in this subregion. Continued fire suppression will eventually allow willow and bog birch to invade many of the grassy meadows.

This community type is slightly drier than the Willow/Water sedge dominated community type.

\section{Plant Composition Canopy Cover(\%)} Mean Range Const.

\section{SHRUBS}

WILLOW

(Salix spp.)

$22 \quad 27-32 \quad 100$

BOG BIRCH

(Betula glandulosa)

SHRUBBY CINQUEFOIL

(Potentilla fruticosa)

9

$1-23 \quad 100$

$3 \quad 1-11 \quad 100$

FORBS

YARROW

(Achillea millefolium)

WILD STRAWBERRY

(Fragaria virginiana)

LINDLEY'S ASTER

(Aster ciliolatus)

BUCK-BEAN

(Menyanthes trifoliata) 2

ARROW-LEAVED COLTSFOOT

(Petasites sagittatus)

\section{Grasses}

TUFTED HAIRGRASS

(Deschampsia cespitosa)

BALTIC RUSH

(Juncus balticus)

SEDGE

(Carex spp.)

HAIRY WILDRYE

(Elymus innovatus)
$0-1 \quad 57$

$0-13 \quad 57$

$0-9 \quad 29$

$0-5 \quad 29$

0-6 29

$0-6 \quad 57$

$0-21 \quad 86$

$42 \quad 15-49 \quad 100$

$1 \quad 0-6 \quad 14$

\section{ENVIRONMENTAL VARIABLES}

MOISTURE REGIME:

MESIC -HYGRIC

NUTRIENT REGIME :

OLIGOTROPIC TO PERMESOTROPHIC

ELEVATION:

1567(1300-1829) M

SOIL DRAINAGE :

WELL TO VERY POORLY

ECOLOGICAL STATUS SCORE: 24

\section{Forage Production Kg/Ha}

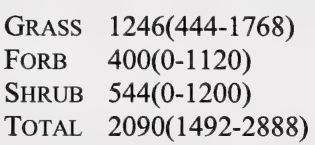

ECOLOGICALLY SUSTAINABLE STOCKING RATE GENERALLY NON-USE $1.0(1.0-0.5) \mathrm{HA} / \mathrm{AUM}$ OR $0.4(0.4-.8) \mathrm{AUM} / \mathrm{AC}$ 


\section{SASMB2. Willow/Richardson needlegrass (Salix spp./Stipa richardsonii)}

$\mathbf{n = 2}$ The ecology of this community type is unclear. Stringer (1973) described a Richardson needlegrass shrub savanna on small isolated areas, south facing slopes amongst subalpine fir, spruce, douglas fir forests in Banff and Jasper National Parks. He felt these grassland types were not closely related to any other grassland types.

Plant Composition Canopy Cover(\%) Mean Range Const.

\section{SHRUBS}

WILLOW SPP.

(Salix myrtillfolia) $\quad 30 \quad 20-40 \quad 100$

BOG BIRCH

(Betula glandulosa) $5 \quad 0-10 \quad 50$

SHRUBBY CINQUEFOIL

(Potentilla fruticosa) $5 \quad 0-10 \quad 50$

\section{FORBS}

SHOWY LOCOWEED

(Oxytropis splendens) $\quad 1 \quad 1-2 \quad 100$

YARROW

$\begin{array}{llll}\text { (Achillea millefolium) } & 1 & 1-2 & 100\end{array}$

FIREWEED

(Epilobium angustifolium) $1 \quad 1-2 \quad 100$

STRAWBERRY

$\begin{array}{llll}\text { (Fragaria virginiana) } \quad 2 & 1-2 & 100\end{array}$

\section{GRASSES}

RICHARDSON NEEDLEGRASS

$\begin{array}{llll}\text { (Stipa richardsonii) } & 45 & 40-50 & 100\end{array}$

ROCKY MTN. FESCUE

$\begin{array}{llll}\text { (Festuca saximontana) } \quad 8 & 5-10 \quad 100\end{array}$

SEDGE

(Carex spp)

$3 \quad 1-5 \quad 100$

QUACK GRASS

(Agropyron repens) $\quad 1 \quad 0-2 \quad 50$

\section{ENVIRONMENTAL VARIABLES}

MOISTURE REGIME:

SUBMESIC

NUTRIENT REGIME:

MESOTROPHIC

ELEVATION:

1375(1300-1450) M

SOIL DRAINAGE:

WELL

ECOLOGICAL STATUS SCORE: 24

FORAGE CAPACITY KG/HA

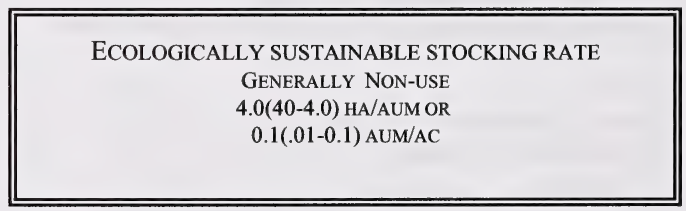




\section{SASMB3. Whitebark pine \\ (Pinus albicaulis)}

$\mathbf{n}=1 \quad$ This is a timberline community type found on steep south facing slopes with subxeric moisture regimes. The trees tend to be very small and shrub like. On moister sites the tree islands would by made up of the subalpine fir community type previously described.

\section{Plant COMPOSITION CANOPY COVER(\%)} MEAN RANGe CONST.

\section{TREES}

WHITE BARK PINE

(Pinus albicaulis)

$$
25
$$

SHRUBS

SMOOTH WILLOW

(Salix glauca)

BUFFALOBERRY

(Shepherdia canadensis)

GROUND JUNIPER

(Juniperus communis)

\section{FORBS}

BEARBERRY

(Arctostaphylos uva-ursi) $2 \quad$ - $\quad 100$

MOUNTAIN GOLDENROD

(Solidago spathulata)

STRAWBERRY

$\begin{array}{llll}\text { (Fragaria virginiana) } & 2 & - & 100\end{array}$

YARROW

$\begin{array}{lll}\text { (Achillea millefolium) } & 1 & -\end{array}$

Grasses

SMOOTH BROME

(Bromus inermis)

SEDGE

(Carex spp.)

HAIRY WILDRYE

(Elymus innovatus)

100

100

100

\section{ENVIRONMENTAL VARIABLES}

MOISTURE REGIME:

SUBXERIC

NUTRIENT REGIME :

MESOTROPHIC

ELEVATION:

$2030 \mathrm{M}$

SOIL DRAINAGE:

RAPIDLY

SLOPE:

$60 \%$

ASPECT:

SOUTHERLY

ECOLOGICAL STATUS SCORE: 24

FORAGE CAPACITY KG/HA

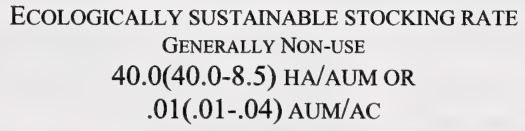




\section{SASMB4. Willow-Bog birch/Rough fescue-Kentucky bluegrass}

\section{(Salix spp.-Betula glandulosalFestuca scabrella-Poa pratensis)}

$\mathbf{n}=\mathbf{2}$ This community type represents the inside transect of a rangeland reference area which has been protected from grazing for over 30 years. This community type represents moist meadows and grasslands in the Sheep area west of Turner valley. Continuous heavy grazing pressure will cause the cover of shrubs and rough fescue to decline and allow Kentucky bluegrass, timothy and dandelion to invade onto the site.

This area of the province is classified as Lower Foothills (Alberta Environmental Protection 1994), but the plant species of this area are more characteristic of the Parkland and Montane subregions and the higher Subalpine subregion than the Lower Foothills. As a result this community type was placed within the Subalpine subregion guide.

\section{Plant Composition Canopy Cover(\%)} Mean Range Const.

SHRUBS

PUSSY WILLOW

(Salix discolor)

BOG BIRCH

\section{(Betula glandulosa)}

SHRUBBY CINQUEFOIL

(Potentilla fruticosa)

$\begin{array}{ccc}18 & 14-21 & 100 \\ 13 & 10-15 & 100 \\ 17 & 5-28 & 100\end{array}$

\section{FORBS}

LINDLEY'S ASTER

(Aster ciliolatus)

WOOLLY CINQUEFOIL

(Potentilla hippiana)

STRAWBERRY

(Fragaria virginiana)

YARROW

(Achillea millefolium)

FIREWEED

(Epilobium angustifolium)

VEINY MEADOW RUE

(Thalictrum venulosum) 3

\section{Grasses}

KENTUCKY BLUEGRASS

(Poa pratensis)

SEDGE

(Carex spp.)

ROUGH FESCUE

(Festuca scabrella)

TUFTED HAIRGRASS

(Deschampsia cespitosa)

$\begin{array}{lll}7 & 6-8 & 100\end{array}$

$3 \quad 0-5 \quad 50$

$6 \quad 2-9 \quad 100$

$2 \quad 2-2 \quad 100$

$0-2 \quad 50$

$2-4 \quad 100$

$10 \quad 0-20 \quad 50$

$5 \quad 4-5 \quad 100$

$12 \quad 11-12 \quad 100$

$2-5 \quad 100$

\section{ENVIRONMENTAL VARIABLES}

MOISTURE REGIME: SUBHYGRIC

NUTRIENT REGIME : PERMESOTROPHIC

ELEVATION: 1425(1400-1450)M

SOIL DRAINAGE: MOD. WELL

SLOPE: $3(2-5) \%$

ASPECT: EASTERLY

ECOLOGICAL STATUS SCORE: 16

Forage Production Kg/HA

GRASS $\quad 250$

FORB $\quad 148$

SHRUB $\quad 1004$

TOTAL 1404

\section{ECOLOGICALLY SUSTAINABLE STOCKING RATE 1.1(1.2-0.9) HA/AUM OR $0.37(.33-0.45) \mathrm{AUM} / \mathrm{AC}$}




\section{SASMB5. Willow/Marsh reedgrass \\ (Salix spp./Calamagrostis canadensis)}

$\mathbf{n}=4$ This community type was described in the Pekisko and Deep Creek allotments which are southwest of Longview. This community represents a small pocket of willow in depressional and seepage areas. It is unusual having a community type dominated by marsh reedgrass in the Subalpine subregion. Marsh reedgrass is more characteristic of wetland sites in the Boreal forest and Lower Foothills subregions of North and Central Alberta. Perhaps this community represents a transition between the Subalpine and lower elevation Montane subregion.

These sites can be highly productive because of the increased moisture and nutrients at the site, but livestock will rarely use these communities and they should be considered non-use.

\section{Plant CoMposition Canopy COVER(\%)} Mean Range Const.

SHRUBS

WILLOW

(Salix spp.)

BOG BIRCH

(Betula glandulosa) $1 \quad 0-3 \quad 25$

FORBS

ARROW-LEAVED COLTSFOOT

(Petasites sagittatus) 2

COMMON HORSETAIL

(Equisetum arvense)

COW PARSNIP

(Heracleum lanatum)

FIREWEED

(Epilobium angustifolium) 4

TALL LARKSPUR

(Delphinium glaucum) 2

VEINY MEADOW RUE

(Delphinium glaucum)

$5 \quad 0-16 \quad 50$

\section{GraSSES}

MARSH REEDGRASS

(Calamagrostis canadensis) 21

Тімотну

(Phleum pratense)

WATER SEDGE

(Carex aquatilis)

$2 \quad 0-8 \quad 25$

$4 \quad 0-10 \quad 50$

7

$0-25 \quad 50$

$0-13 \quad 50$

$0-7 \quad 50$

$0-16 \quad 50$

$15-25 \quad 100$

$0-3 \quad 50$

$0-29 \quad 50$

\section{ENVIRONMENTAL VARIABLES}

MOISTURE REGIME : SUBHYGRIC-HYGRIC

NUTRIENT REGIME:

PERMESOTROPHIC-EUTROPHIC

ElEVATION:

1550(1390-1737)M

SOIL DRAINAGE:

IMPERFECTLY

SLOPE:

$2(0-5) \%$

ASPECT:

LEVEL

ECOLOGICAL STATUS SCORE: 24

Forage Production Kg/HA

GRASS 900(540-1260)

FORB 88(76-100)

SHRUB 1276(844-1708)

TOTAL 1916(1509-2324)

ECOLOGICALLY SUSTAINABLE STOCKING RATE

GENERALLY NON-USE

$1.0(1.0-0.4) \mathrm{HA} / \mathrm{AUM}$

$0.4(0.4-1.01) \mathrm{AUM} / \mathrm{AC}$ 


\section{SASMB6. Smooth willow-Shrubby cinquefoil/Hairy wildrye}

(Salix glauca-Potentilla fruticosa/Elymus innovatus)

$\mathbf{n}=\mathbf{1}$ This community type was described on mesic lower slope positions in the Upper Subalpine at or near treeline. Snow accumulates on these sites or seepage occurs during the growing season favoring the growth of willow. This community type is moister and has better developed soils than the smooth willow-juniper community that occurs on similar slope positions. This community type is moderately productive for domestic livestock, but the high elevation will often limit accessibility. Grazing of this community should be done with caution because recovery from over-grazing will take some time because of the poor growing conditions.

\section{Plant COMPOSITION CANOPY Cover(\%)} Mean Range Const.

TREES

ENGELMANN SPRUCE

(Picea engelmannii)

$1 \quad-\quad 100$

\section{SHRUBS}

SMOOTH WILLOW

(Salix glauca)

SHRUBBY CINQUEFOIL

(Potentilla fruticosa)

$\begin{array}{lll}50 & - & 100 \\ 3 & - & 100\end{array}$

FORBS

ALPINE HEDYSARUM

$\begin{array}{llll}\text { (Hedysarum alpinum) } & 8 & - & 100\end{array}$

FIREWEED

(Epilobium angustifolium)5 $\quad$ - $\quad 100$

SWEET FLOWERED ANDROSACE

(Androsace chamaejasme) $3 \quad$ - 100

STRAWBERRY

$\begin{array}{llll}\text { (Fragaria virginiana) } & 3 & - & 100\end{array}$

\section{GRASSES}

HAIRY WILDRYE

$\begin{array}{llll}\text { (Elymus innovatus) } & 9 & - & 100\end{array}$

SEDGE

(Carex spp.)

SHEEP FESCUE

(Festuca saximontana)

\section{ENVIRONMENTAL VARIABLES}

MOISTURE REGIME :

MESIC

NUTRIENT REGIME:

SUBMESOTROPHIC

ELEVATION:

$1940 \mathrm{M}$

SOIL DRAINAGE:

WELL

SLOPE:

$20 \%$

ASPECT:

EASTERLY

ECOLOGICAL STATUS SCORE: 24

Forage Production Kg/Ha

GRASS $\quad 810$

FORB $\quad 712$

SHRUB $\quad 716$

TOTAL 2238

ECOLOGICALLY SUSTAINABLE STOCKING RATE

$1.0(1.3-0.9) \mathrm{HA} / \mathrm{AUM} \mathrm{OR}$ $0.4(0.31-0.45) \mathrm{AUM} / \mathrm{AC}$ 


\section{SASMB7. Smooth willow-Juniper/Hairy wildrye \\ (Salix glauca-Juniperus communis/Elymus innovatus)}

$\mathbf{n}=\mathbf{3}$ This community type occurs on steep subxeric slopes in the Upper Subalpine. Corns and Achuff (1982) described a similar community type on steep southerly facing slopes in Banff and Jasper National Parks. They felt that these sites were commonly snow avalanched. The snow accumulation appears to favour the growth of willow. Willow cover on this community type is quite variable. Where snow accumulates willow cover will be fairly dense. This community type is moderately productive for domestic livestock, but the high elevation will often limit accessibility. Grazing of this community type should be done with caution because recovery from over-grazing will take some time because of the poor growing conditions.

\section{Plant Composition Canopy Cover(\%)} Mean Range Const.

TREES

ENGELMANN SPRUCE

(Picea engelmannii)

$4 \quad 1-7 \quad 100$

\section{SHRUBS}

SMOOTH WILLOW

(Salix glauca)

COMMON JUNIPER

(Juniperus communis)

SHRUBBY CINQUEFOIL

(Potentilla fruticosa

13

13

$3-30$

100

6

$1-15$

100

1

$0-2$

66

\section{FORBS}

BEARBERRY

(Arctostaphylos uva-ursi) 3

ALPINE HEDYSARUM

(Hedysarum alpinum) 5

ALPINE GOLDENROD

(Solidago multiradiata) 3

FIREWEED

(Epilobium angustifolium)1

\section{Grasses}

HAIRY WILDRYE

\begin{tabular}{|c|c|c|c|}
\hline (Elymus innovatus) & 8 & $2-11$ & 10 \\
\hline ROUGH FESCUE & & & \\
\hline (Festuca scabrella) & 2 & $0-4$ & \\
\hline SEDGE & & & \\
\hline (Carex spp.) & 1 & $1-2$ & \\
\hline
\end{tabular}

\section{ENVIRONMENTAL VARIABLES}

MOISTURE REGIME :

XERIC-SUBXERIC

NUTRIENT REGIME:

SUBMESOTROPHIC

ELEVATION:

2013(2000-2026)M

SOIL DRAINAGE:

RAPIDLY

SLOPE:

$65(60-70) \%$

ASPECT:

EASTERLY

ECOLOGICAL STATUS SCORE: 24

\section{Forage Production KG/HA}

$\begin{array}{ll}\text { GRASS } & 572(568-576) \\ \text { FORB } & 421(388-454) \\ \text { SHRUB } & 235(0-470) \\ \text { TOTAL } & 1228(956-1500)\end{array}$

ECOLOGICALLY SUSTAINABLE STOCKING RATE 1.2(1.3-0.9) HA/AUM OR $0.33(0.31-0.45)$ AUM/AC 


\section{SASMB8 Willow/Tufted hairgrass-Kentucky bluegrass \\ (Salix spp./Deschampsia cespitosa-Poa pratensis)}

$\mathbf{n}=\mathbf{1}$ This community type represents the grazed and disturbed community of the Willow/Tufted hairgrass-Sedge community. Continued heavy grazing will often lead to a Willow/Kentucky bluegrass dominated community type. The high productivity and open nature of this community make it extremely attractive fo domestic livestock.

\section{Plant CoMposition Canopy Cover(\%)} Mean Range Const.

TREES

LODGEPOLE PINE

(Pinus contorta)

$4 \quad-\quad 100$

SHRUBS

BASKET WILLOW

(Salix petiolaris)

SHRUBBY CINQUEFOIL

(Potentilla fruticosa)

25

100

FORBS

LINDLEY'S ASTER

(Aster ciliolatus)

MOUNTAIN VALERIAN

(Valeriana dioica)

VEINY MEADOW RUE

(Thalictrum venulosum)

GRACEFUL CINQUEFOIL

$$
\text { (Potentilla gracilis) }
$$

$\begin{array}{lll}3 & - & 100 \\ 2 & - & 100 \\ 2 & - & 100 \\ 2 & - & 100\end{array}$

\section{GrasseS}

TUFTED HAIRGRASS

(Deschampsia cespitosa) $21 \quad-\quad 100$
ТімОтну

$\begin{array}{llll}\text { (Phleum pratense) } & 3 & - & 100\end{array}$

KENTUCKY BLUEGRASS

(Poa pratensis)

CREEPING RED FESCUE

(Festuca rubra)

SEDGE

(Carex spp.)

\section{2}

5

4

\section{ENVIRONMENTAL VARIABLES}

MOISTURE REGIME :

SUBHYGRIC

NUTRIENT REGIME:

PERMESOTROPHIC

ELEVATION:

$1600 \mathrm{M}$

SOIL DRAINAGE:

MOD. WELL

SLOPE:

$5 \%$

ASPECT:

WEST

ECOLOGICAL STATUS SCORE: 16

Forage Production KG/HA

GRASS $\quad 1734$

FORB 248

TOTAL 1982

ECOLOGICALLY SUSTAINABLE STOCKING RATE

$1.0(1.1-0.8) \mathrm{HA} / \mathrm{AUM} \mathrm{OR}$

$0.4(0.36-0.5) \mathrm{AUM} / \mathrm{AC}$ 


\section{SASMB9 Bebb willow/Pinegrass \\ (Salix bebbiana/Calamagrostis rubescens)}

$\mathbf{n}=\mathbf{1}$ This community type represents the ecotone between moist lower slope positions that are dominated by willow and forest communities dominated by lodgepole pine. Plant species characteristic of both moist and mesic moisture regimes can be found in this community type making the community very diverse. In the absence of disturbance the site will eventually become drier and it will likely succeed to a lodgepole pine dominated community. The shrub and tree cover are so dense in this community that livestock have a difficult time accessing the forage. Consequently, this community type should be rated as non-use.

Plant Composition Canopy Cover(\%) Mean Range Const.

\section{TREES}

LODGEPOLE PINE

(Pinus contorta)

WHITE SPRUCE

(Picea glauca)

SHRUBS

BEBB WILLOW

(Salix bebbiana)

BRACTED HONEYSUCKLE

(Lonicera involcrata)

PRICKLY ROSE

(Rosa acicularis)

100

$10 \quad-\quad 100$

$51 \quad-\quad 100$

$3-100$

$2 \quad-\quad 100$

\section{FORBS}

LINDLEY'S ASTER

(Aster ciliolatus)

SCOURING RUSH

(Equisetum scirpoides)

FIREWEED

(Epilobium angustifolium) $9 \quad$ - $\quad 100$

STRAWBERRY

$\begin{array}{llll}\text { (Fragaria virginiana) } & 6 & - & 100\end{array}$

Grasses

TUFTED HAIRGRASS

(Deschampsia cespitosa) 4

PINEGRASS

(Calamagrostis rubescens)5

SEDGE BEAKED

(Carex rostrata)

\section{ENVIRONMENTAL VARIABLES}

MOISTURE REGIME : HYGRIC

NUTRIENT REGIME: PERMESOTROPHIC

ELEVATION: $1600 \mathrm{M}$

SOIL DRAINAGE: IMPERFECTLY

SLOPE:

$5 \%$

ASPECT:

EASTERLY

ECOLOGICAL STATUS SCORE: 24

Forage Production Kg/HA

GRASS 150

FORB $\quad 100$

SHRUB $\quad 1000$

TOTAL 1250

ECOLOGICALLY SUSTAINABLE STOCKING RATE GENERALLY NON-USE

$3.6(5.0-2.0) \mathrm{HA} / \mathrm{AUM}$

$0.17(0.08-0.2) \mathrm{AUM} / \mathrm{AC}$ 


\title{
SASMC1. Parry oatgrass-Rough fescue-Kentucky bluegrass
}

\author{
(Danthonia parryii-Festuca scabrella-Poa pratensis)
}

$\mathbf{n = 8}$ This community type represents the grazing disclimax community of the Rough fescue-Idaho fescue-Parry oatgrass community type. Increased grazing pressure favours the growth of Parry oatgrass and sedge over rough fescue. Continued heavy grazing pressure eventually leads to a decline in all native species and the site is often dominated by only Kentucky bluegrass, timothy and dandelion. Recovery of this community type back to a rough fescue dominated site is possible with a reduction in grazing pressure, but once Kentucky bluegrass establishes in the stand it will likely remain as a co-dominant.

This community type is very productive and should be considered primary range.

\section{Plant Composition Canopy Cover(\%) Mean Range Const.}

\section{SHRUBS}

PRICKLY ROSE

(Rosa acicularis)

SASKATOON

(Amelanchier alnifolia)

(Potentilla fruticosa)

FORBS

YARROW

(Achillea millefolium)
WILD STRAWBERRY

(Fragaria virginiana)

THREE FLOWERED AVENS

(Geum triflorum)

GRACEFUL CINQUEFOIL

(Potentilla gracilis)

DANDELION

(Taraxacum officinale)

AMERICAN VETCH

(Vicia americana)

GRASSES

PARRY OATGRASS

(Danthonia parryi)

ROUGH FESCUE

(Festuca scabrella)

KENTUCKY BLUEGRASS

(Poa pratensis)

IDAHO FESCUE

(Festuca idahoensis)

Тімотну

(Phleum pratense)
4

$1 \quad 0-3$

64

1

$0-1 \quad 13$

$4 \quad 0-9 \quad 88$

88

\section{ENVIRONMENTAL VARIABLES}

MoISTURE REgIME :

XERIC TO SUBMESIC

NUTRIENT REGIME :

ELEVATION:

SUBMESOTROPHIC TO MESOTROPHIC

SOIL DRAINAGE :

1502(1397-1601)M

RAPIDLY TO WELL

SLOPE:

$$
19(0-50) \%
$$

ASPECT:

\section{SOUTH EASTERLY}

ECOLOGICAL STATUS SCORE: 16 OR 8

\section{Forage Production Kg/HA}

$$
\begin{array}{ll}
\text { GrASS } & 1234(654-1602) \\
\text { FORB } & 640(382-1140) \\
\text { SHRUB } & 19(0-118) \\
\text { TOTAL } & 1613(660-2448)
\end{array}
$$

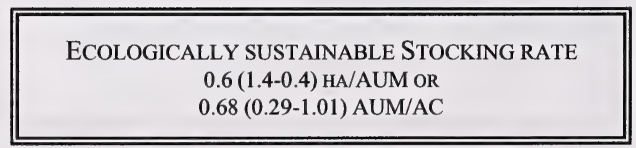




\section{SASMC2. Parry oatgrass-Kentucky bluegrass-Sedge \\ (Danthonia parryi-Poa pratensis-Carex spp.)}

$\mathbf{n}=7$ This community type represents a heavily grazed Parry oatgrass-Rough fescue-Sedge community type. Heavy grazing pressure favours the growth of grazing resistant species of Kentucky bluegrass and sedge and causes rough fescue to decline. Continued heavy grazing pressure will eventually lead to a community type that is dominated by Kentucky bluegrass, timothy and sedge. If the grazing pressure is reduced on this community type there is a good possibility of recovery.

\section{Plant Composition Canopy Cover(\%)}

SHRUBS

SHRUBBY CINQUEFOIL

(Potentilla fruticosa) $\quad 6 \quad 1-15 \quad 100$

SASKATOON

(Amelanchier alnifolia) $\quad 5 \quad 0-23 \quad 57$

\section{FORBS}

THREE FLOWERED AVENS

(Geum triflorum) 3

EARLY YELLOW LOCOWEED

(Oxytropis sericea)

SILKY PERENNIAL LUPINe

(Lupinus sericeus)
CUT-LEAVED ANEMONE

(Anemone multifida)

GrasseS

PARRY OATGRASS

(Danthonia parryi)

KENTUCKY BLUEGRASS

(Poa pratensis)

SEDGE

(Carex spp)

JUNEGRASS

(Koeleria macrantha)

ТімотнY

(Phleum pratense)

ROUGH FESCUE

(Festuca scabrella)

3

3

2

mean Range Const.

$0-16 \quad 71$

$0-14 \quad 57$

$0-5 \quad 71$

$15 \quad 6-22 \quad 100$

$13 \quad 2-27 \quad 100$

0-6 $\quad 84$

$0-7 \quad 84$

$3-84$

$3 \quad 0-15 \quad 71$

$3 \quad 1-9 \quad 100$

\section{ENVIRONMENTAL VARIABLES}

MOISTURE REGIME:

Xeric TO SUBMesiC

NUTRIENT REGIME:

SUBMESOTROPHIC TO MESOTROPHIC

ELEVATION:

$1411(1400-1441) \mathrm{M}$

SOIL DRAINAGE:

RAPIDLY

SLOPE:

$25(13-30) \%$

ASPECT:

SOUTHWESTERLY

ECOLOGICAL STATUS SCORE: 16 OR 8

Forage Production Kg/HA

GRASS $1140(0-2018)$

FORB 685(108-2330)

SHRUB 79(0-238)

TotaL 1894(1408-2330)
ECOLOGICALLY SUSTAINABLE STOCKING RATE $0.8(1.4-0.4) \mathrm{HA} / \mathrm{AUM}$ OR $0.5(0.29-1.0) \mathrm{AUM} / \mathrm{AC}$ 


\section{SASMC3. Meadow foxtail-Kentucky bluegrass \\ (Alopecurus pratensis-Poa pratensis)}

$\mathbf{n}=3$ This community type was described in the South Sheep allotment. It represents small aspen stands that were cleared and seeded to a mixture of meadow brome, creeping red fescue, clover and meadow foxtail. These sites have continued to be heavily grazed which has favoured the growth of meadow foxtail, Kentucky bluegrass and clover. Meadow foxtail is not particularly palatable to livestock and therefore gains a competitive advantage over meadow brome and creeping red fescue, in these seeded areas.

\section{PLANTCOMPOSITIONCANOPYCOVER(\%) Mean Range Const.}

\section{SHRUBS}

SHRUBBY CINQUEFOIL

(Potentilla fruticosa)

PRICKLY ROSE

(Rosa acicularis)

\section{$\mathrm{T}$}

$\mathrm{T}$

FORBS

COMMON DANDELION

(Taraxacum officinale) 8

STICKY PURPLE GERANIUM

(Geranium viscosissimum) 1

Clover

(Trifolium spp.)

WESTERN MEADOW RUE

(Thalictrum occidentale) 3

\section{GRASSES}

MEADOW FOXTAIL

$\begin{array}{llll}\begin{array}{l}\text { (Alopecurus pratensis) } \\ \text { SEDGE }\end{array} & 23 & 14-33 & 100 \\ \begin{array}{l}\text { (Carex spp.) } \\ \text { KENTUCKY BLUEGRASS }\end{array} & 4 & 1-6 & 100 \\ \begin{array}{l}\text { (Poa pratensis) } \\ \text { TIMOTHY }\end{array} & 24 & 14-36 & 100 \\ \begin{array}{l}\text { (Phleum pratense) } \\ \text { RED FESCUE } \\ \text { (Festuca rubra) }\end{array} & 1 & 1-2 & 100 \\ & 6 & 0-15 & 67\end{array}$

\section{ENVIRONMENTAL VARIABLES}

MOISTURE REGIME:

MESIC TO SUBHYGRIC

NUTRIENT REGIME:

MESOTROPHIC TO PERMESOTROPHIC

ELEVATION:

1375(1300-1424)M

SOIL DRAINAGE:

WELL TO MODERATELY WELL

SLOPE:

$$
7(2-10) \%
$$

ASPECT:

SOUTHERLY

ECOLOGICAL STATUS SCORE: MODIFIED OR TAME PASTURE

\section{Forage Production Kg/HA}

$$
\begin{array}{cl}
\text { GRASS } & 2775(2552-3132) \\
\text { FORBS } & 507(306-608) \\
\text { TOTAL } & 3282(2946-3160)
\end{array}
$$

ECOLOGICALLY SUSTAINABLE STOCKING RATE $0.5(0.9-0.3) \mathrm{HA} / \mathrm{AUM}$ $0.8(0.45-1.35) \mathrm{AUM} / \mathrm{AC}$ 


\section{SASMC4. Fringed sage/Kentucky bluegrass-Parry oatgrass}

\section{(Artemisia frigida/Poa pratensis-Danthonia parryi)}

$\mathbf{n}=1$ This community type was described on a south facing slope and ridge top in the South Sheep allotment. It appears to represent long-term heavy grazing pressure on a Parry oatgrass-Rough fescue-Sedge dominated community type. The increased grazing pressure on these south facing slopes favours the growth of fringed sage, sedge, Kentucky bluegrass and dandelion. It is unusual having such a high cover of Kentucky bluegrass on these slopes. Kentucky bluegrass usually prefers moister lower slope positions. Perhaps the higher precipitation received in the Subalpine subregion compared to the Montane makes the south facing slopes more favorable to Kentucky bluegrass invasion.

There is still a strong component of native species in this community type and recovery is likely if the grazing pressure is reduced.

\section{PlantCompositioncanopyCover(\%)} Mean Range Const.

\section{SHRUBS}

PASTURE SAGE

(Artemisia frigida)

$16 \quad-\quad 100$

SHRUBBY CINQUEFOIL

(Potentilla fruticosa)

4

100

\section{FORBS}

GOLDEN BEAN

(Thermopsis rhombifolia)5

EARLY YELLOW LOCOWEED

(Oxytropis sericea)

COMMON DANDELION

(Taraxacum officinale)

NATIVE VETCH

(Vicia americana)

COMMON GOATS BEARD

(Tragopogon dubius)

2

2

2

1

GRASSES

KENTUCKY BLUEGRASS

(Poa pratensis)

PARRY OATGRASS

(Danthonia parryi)

ROUGH FESCUE

(Festuca scabrella.) 8

COLUMBIA NEEDLE GRASS

(Stipa columbiana) 8

JUNEGRASS

(Koeleria macrantha)

SEDGE SPP.

(Carex spp.)

\section{ENVIRONMENTAL VARIABLES}

MOISTURE REGIME:

XERIC

NUTRIENT REGIME:

SUBMESOTROPHIC

ELEVATION:

$1450 \mathrm{M}$

SOIL DRAINAGE:

RAPIDLY

SLOPE:

$33 \%$

ASPECT:

SOUTHERLY

ECOLOGICAL STATUS SCORE: 8 OR 0

Forage Production KG/HA

GRASS 704

FORB $\quad 490$

SHRUB 236

TOTAL 1430
ECOLOGICALLY SUSTAINABLE STOCKING RATE

1.0(1.2-0.6) HA/AUM

0.4(0.33-0.67) AUM/AC 


\section{SASMC5. Rough fescue-Kentucky bluegrass}

(Festuca scabrella-Poa pratensis)

$\mathbf{n}=\mathbf{3}$ This community type was described in the South Sheep allotment west of Turner valley and represents a rough fescue grassland that has been heavily grazed to the point of Kentucky bluegrass invasion and is now recovering. Long-term heavy grazing pressure leads to a decline in rough fescue and an increase in Parry oatgrass and sedge species. Continued grazing pressure reduces the competitive advantage of rough fescue and the other native grass species and allows Kentucky bluegrass to establish on site. Protection or a reduction in stocking level at the point where Kentucky bluegrass becomes a significant of the community allows rough fescue to recover, but it seems Kentucky bluegrass also remains as co-dominant.

Plant Composition Canopy Cover(\%) Mean Range Const.

\section{SHRUBS}

SHRUBBY CINQUEFOIL

(Potentilla fruticosa)

$$
5
$$

$1-8$

100

\section{FORBS}

OLD MAN WHISKER'S

(Geum triflorum)

GRACEFUL CINQUEFOIL

(Potentilla gracilis)

NORTHERN BEDSTRAW

(Galium boreale)

YARROW

(Achillea millefolium)

\section{Grasses}

KENTUCKY BLUEGRASS

(Poa pratensis)

CALIFORNIA OATGRASS

(Danthonia californica)

ROUGH FESCUE

(Festuca scabrella.)

HAIRY WILDRYE

(Elymus innovatus)

IDAHO FESCUE

(Festuca idahoensis)

SLENDER WHEATGRASS

(Agropyron trachycaulum)3

$2 \quad 1-3 \quad 100$

$2 \quad 1-3 \quad 100$

$2 \quad 1-2 \quad 100$

$2 \quad 1-2 \quad 100$

$13 \quad 7-20 \quad 100$

$0-15 \quad 67$

$20 \quad 11-35 \quad 100$

$1 \quad 0-4 \quad 67$

$2 \quad 1-3 \quad 100$

$1-4 \quad 100$

\section{ENVIRONMENTAL VARIABLES}

MOISTURE REGIME:

MESIC-SuBMESIC

NUTRIENT REGIME:

MESOTROPHIC- PERMESOTROPHIC

ELEVATION:

1663(1500-1672)M

SOIL DRAINAGE:

WELL-RAPIDLY

SLOPE:

$$
27(0-50) \%
$$

ASPECT:

SOUTHERLY

ECOLOGICAL STATUS SCORE: 24 OR 16

Forage Production KG/HA

GRASS 1400(1356-1444)

FORB 485(190-780)

TOTAL 1885(1546-2224)

ECOLOGICALLY SUSTAINABLE STOCKING RATE

$0.5(0.6-0.4) \mathrm{HA} / \mathrm{AUM}$ OR

$0.81(0.68-1.01) \mathrm{AUM} / \mathrm{AC}$ 


\section{SASMA5. Kentucky bluegrass/Dandelion \\ (Poa pratensis/Taraxacum officinale)}

$\mathbf{n = 2 0}$ This community type represents a moist, tufted hairgrass-sedge dominated community type that has been heavily grazed. Heavy grazing pressure causes tufted hairgrass to decline and allows sedge and Kentucky bluegrass to increase. Continuous heavy grazing pressure will eventually cause all native species to decline on the site and the site will become dominated by Kentucky bluegrass, dandelion and clover (Willoughby 1992).

Plant Composition Canopy Cover(\%)

\section{SHRUBS}

Mean RANGe CONST.

BRISTLY BLACK CURRANT
(Ribes lacustre)
$\begin{array}{lll}1 & 0-7\end{array}$
7

\section{FORBS}

DANDELION

(Taraxacum officinale) 10

YARROW

(Achillea millefolium) $\quad 62-28 \quad 100$

FIREWEED

(Epilobium angustifolium)2

GRACEFUL CINQUEFOIL

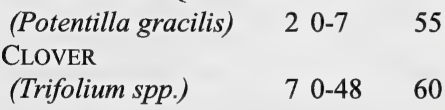

\section{GraSSES}

KENTUCKY BLUEGRASS

(Poa pratensis)

RUSH LIKE SEDGE

(Carex scirpoidea) 32

TUFTED HAIRGRASS

(Deschampsia cespitosum) $1 \quad 0-5$

TIMOTHY

(Phleum pratense) $\quad 11 \quad 0-28 \quad 70$
SUBHYGRIC

NUTRIENT REGIME:

PERMESOTROPHIC

ELEVATION:

1507(1340-1798)M

SOIL DRAINAGE:

MODERATELY WELL

SLOPE:

$6(0-20) \%$

ASPECT:

VARIABLE

ECOLOGICAL STATUS SCORE: 0

\section{Forage Production Kg/HA}

$\begin{array}{ll}\text { GRASS } & 1708(248-3700) \\ \text { FORB } & 403(252-889) \\ \text { SHRUB } & 104(0-198) \\ \text { TOTAL } & 2170(746-4589)\end{array}$

ECOLOGICALLY SUSTAINABLE STOCKING RATE

$0.9(1.2-0.2) \mathrm{HA} / \mathrm{AUM}$ OR $0.45(0.34-2.04) \mathrm{AUM} / \mathrm{AC}$

\section{ENVIRONMENTAL VARIABLES}

MOISTURE REGIME: 


\section{SASMC6. Kentucky bluegrass-Rough fescue \\ (Poa pratensis-Festuca scabrella)}

$\mathbf{n = 1 7}$ Long-term heavy grazing pressure leads to a decline in rough fescue and an increase in Parry oatgrass and sedge species. Continued grazing pressure reduces the competitive advantage of rough fescue and the other native grass species and allows Kentucky bluegrass to establish on site. Continued heavy grazing pressure eventually leads to a decline in all native species and the plant community will resemble a Timothy-Kentucky bluegrass/dandelion type.

The forage productivity of this community type $(2300 \mathrm{~kg} / \mathrm{ha})$ is equivalent to or better than a lightly grazed Rough fescue dominated community $(1900 \mathrm{~kg} / \mathrm{ha})$. However, rough fescue is a more desirable forage species because it maintains it nutrient content into the dormant season. In contrast, Kentucky bluegrass loses its palatability and nutrient content if is allowed to flower and set seed.

\section{Plant Composition Canopy Cover(\%)} Mean Range Const.

\section{SHRUBS}

SHRUBBY CINQUEFOIL

(Potentilla fruticosa)

$2 \quad 0-15 \quad 83$

FORBS

THREE FLOWERED AVENS

(Geum triflorum)

WILD STRAWBERRY

(Fragaria virginiana)

GRACEFUL CINQUEFOIL

(Potentilla gracilis) 3

LATE YELLOW LOCOWEED

(Oxytropis monticola) 1

YELLOW FALSE DANDELION

(Agoseris glauca)

DANDELION

(Taraxacum officinale)

$3 \quad 0-16 \quad 79$

$2 \quad 0-8 \quad 88$

$3 \quad 0-13 \quad 77$

$0-5 \quad 47$

$0-10 \quad 53$

$0-12 \quad 88$

GRASSES

KENTUCKY BLUEGRASS

(Poa pratensis P.compressa) $12 \quad 2-21 \quad 100$

TімотнY

$\begin{array}{llll}\text { (Phleum pratense) } & 5 & 0-26 & 82\end{array}$

ROUGH FESCUE

(Festuca scabrella.) $\quad 1 \quad 0-5 \quad 59$

IDAHO FESCUE

(Festuca idahoensis) $\quad 1 \quad 0-12-53$
MOISTURE REGIME:

SUBXERIC TO SUBHYGRIC

NUTRIENT REGIME:

SUBMESOTROPHIC TO PERMESOTROPHIC

(POOR TO RICH)

ELEVATION:

$1623(1502-1798) \mathrm{M}$

SOIL DRAINAGE:

VERY RAPIDLY TO MODERATELY WELL

SLOPE: $\quad 220(2-45) \%$

ASPECT: VARIABLE

ECOLOGICAL STATUS SCORE: 8

Forage Production Kg/HA

GRASS 1284(85-3584)

FORB 781(126-2312)

SHRUB 120-45)

TOTAL 2072(421-4733)

ECOLOGICALLY SUSTAINABLE STOCKING RATE $0.8(2.2-0.4) \mathrm{HA} / \mathrm{AUM}$ or $0.5(0.18-1.01)) \mathrm{AUM} / \mathrm{AC}$ 


\section{SASMC7. Timothy-Kentucky bluegrass/Fireweed \\ (Phleum pratense-Agropyron trachycaulum/Epilobium angustifolium)}

$\mathbf{n = 8} \quad$ This community type was described in moist lower slope positions. Heavy grazing pressure has caused the native grass species to decline and allowed Canada bluegrass and timothy to invade onto the site. The presence of fireweed indicates that the site will likely succeed to an aspen dominated community type.

This community type is highly productive and it is easily accessible to domestic livestock. It should be rated as primary range.

\section{Plant Composition Canopy Cover(\%)} Mean Range Const.

\section{SHRUBS}

PRICKLY ROSE

(Rosa acicularis)

SHRUBBY CINQUEFOIL

(Potentilla fruticosa)

$\begin{array}{lll}2 & 0-10 & 50 \\ 1 & 0-2 & 38\end{array}$

FORBS

GRACEFUL CINQUEFOIL

(Potentilla gracilis) 6

FIREWEED

(Epilobium angustifolium)2

COMMON DANDELION

(Taraxacum officinale) 11

NATIVE VETCH

(Vicia americana) 3

STICKY PURPLE GERANIUM

(Geranium viscosissimum)5

Grasses

TIMOTHY

(Phleum pratense)

50

SLENDER WHEATGRASS

(Agropyron trachycaulum)2

ROUGH FESCUE

(Festuca scabrella.)

(Danthonia californica)

KENTUCKY BLUEGRASS

(Poa pratensis)

SEDGE

(Carex spp.)
$1-13 \quad 100$

$0-8 \quad 86$

$1-26 \quad 100$

$0-7 \quad 86$

$0-15 \quad 86$

19-64 100

$0-10 \quad 42$

$0-4 \quad 71$

$0-15 \quad 14$

$0-11 \quad 86$

$0-10 \quad 88$

\section{ENVIRONMENTAL VARIABLES}

MOISTURE REGIME:

MESIC

NUTRIENT REGIME:

MESOTROPHIC

ELEVATION:

1511(1524-1655)M

SOIL DRAINAGE:

WELL

SLOPE:

$5(1-5) \%$

ASPECT:

VARIABLE

ECOLOGICAL STATUS SCORE: 0 OR MODIFIED

\section{Forage Production Kg/HA}

GRASS 4030(1368-7740)

FORB 863(550-1060)

SHRUB 33(0-144)

TOTAL 4926(2482-8494)

ECOLOGICALLY SUSTAINABLE STOCKING RATE $0.5(0.8-0.2) \mathrm{HA} / \mathrm{AUM}$ OR $0.8(0.5-2.04 \mathrm{AUM} / \mathrm{AC}$ 


\section{SASMC8. Marsh reedgrass-Timothy/Cow parnsip \\ (Calamagrostis canadensis-Phleum pratense/Heracleum lanatum)}

$\mathbf{n = 1}$ This community type represents seepage areas in the foothills west of Turner valley. Often these areas are invaded by willow to form the Willow/Marsh reedgrass dominated community type. This community type is very similar to the Marsh reedgrass/Cow parnsip community previously described, but this community has a high cover of timothy. Timothy, Kentucky bluegrass and dandelion will often invade these sites when exposed to heavy grazing pressure. This community type is highly productive and should be rated as primary range.

\section{Plant Composition Canopy Cover(\%) Mean RANGe CONST.}

\section{SHRUBS}

RASPBERRY

(Rubus idaeus)

$6 \quad-\quad 100$

FORBS

COW PARSNIP

(Heracleum lanatum) 28

FIREWEED

(Epilobium angustifolium)3

COMMON DANDELION

(Taraxacum officinale)

CANADA VIOLET

(Viola canadensis)

WHITE GERANIUM

(Geranium richardsonii) 10

WESTERN MEADOW RUE

(Thalictrum occidentalis) 15

15

GRASSES

TIMOTHY

(Phleum pratense) 29

SLENDER WHEATGRASS

(Agropyron trachycaulum)3

MOUNTAIN BROME

$\begin{array}{llll}\text { (Bromus carinatus.) } & 2 & - & 100\end{array}$

MARSH REEDGRASS

(Calamagrostis canadensis) 37
MOISTURE REGIME:

SUBHYGRIC

NUTRIENT REGIME:

PERMESOTROPHIC

ELEVATION:

$1570 \mathrm{M}$

SOIL DRAINAGE:

MOD. WELL

SLOPE:

$10 \%$

ASPECT:

VARIABLE

ECOLOGICAL STATUS SCORE: 8

Forage Production Kg/HA

GRASS 1369

FORB $\quad 1245$

TOTAL 2613

ECOLOGICALLY SUSTAINABLE STOCKING RATE

$0.8(1.0-0.5) \mathrm{HA} / \mathrm{AUM}$ OR 0.5(0.4-0.8) AUM/AC 


\section{SASMC9. Idaho fescue-Rough fescue/Bearberry \\ (Festuca idahoensis-Festuca scabrella/Arctostaphylos uva-ursi)}

$\mathbf{n}=\mathbf{2}$ This community type represents a Rough fescue/Bearberry plant community that has been heavily to moderately grazed for a number of years. Increased grazing pressure causes rough fescue to decline and allows Idaho fescue, timothy and sedge species to increase. If grazing pressure is reduced on this site it will likely succeed back to a rough fescue dominated community.

\section{Plant Composition Canopy Cover(\%) Mean Range Const.}

\section{SHRUBS}

SHRUBBY CINQUEFOIL

(Potentilla fruticosa)

COMMON JUNIPER

(Juniperus communis)

$1 \quad 1-2 \quad 100$

$7 \quad 0-15 \quad 50$

FORBS

BEARBERRY

(Arctostaphylos uva-ursi) 22

OLD MANS WHISKERS

$\begin{array}{llll}\text { (Geum triflorum) } & 16 & 4-27 & 100\end{array}$

STRAWBERRY

$\begin{array}{llll}\text { (Fragaria virginiana) } & 11 & 4-16 & 100\end{array}$

YARROW

$\begin{array}{llll}\text { (Achillea millefolium) } & 7 & 6-8 & 100\end{array}$

NORTHERN BEDSTRAW

(Galium boreale)

AMERICAN VETCH

(Vicia americana)

$\begin{array}{lll}6 & 5-7 \quad 100\end{array}$

$\begin{array}{lll}6 & 2-9 & 100\end{array}$

Grasses

IDAHO FESCUE

$\begin{array}{llll}\text { (Festuca idahoensis) } & 26 & 20-31 & 100\end{array}$

ROUGH FESCUE

(Festuca scabrella)

NORTHERN WHEATGRASS

(Agropyron dasystachyum)5

JUNEGRASS

$\begin{array}{llll}\text { (Koeleria macrantha) } & 4 & 1-6 & 100\end{array}$

\section{ENVIRONMENTAL VARIABLES}

MOISTURE REGIME:

SUBMESIC

NUTRIENT REGIME:

MESOTROPHIC

ELEVATION:

$1500-1510(1505 \mathrm{M})$

SOIL DRAINAGE:

WELL

SLOPE:

ASPECT:

VARIABLE

ECOLOGICAL STATUS SCORE: 16

\section{Forage Production Kg/Ha}

GRASS 1408(1012-1804)

FORB 862(434-1290)

SHRUB 43(0-86)

TOTAL 2313(2302-2324)

ECOLOGICALLY SUSTAINABLE STOCKING RATE

$1.6(1.8-0.7) \mathrm{HA} / \mathrm{AUM}$ OR

$0.25(0.22-0.57) \mathrm{AUM} / \mathrm{AC}$ 


\section{SASMC10. Tufted hairgrass-Kentucky bluegrass (Deschampsia cespitosa-Poa pratensis)}

$\mathbf{n}=\mathbf{2}$ This community type is similar to the other Kentucky bluegrass dominated community types, but grazing pressure has been lighter or it was heavy and then became more moderate because of reduced stocking rates or rotational grazing. Willoughby (1992), found that tufted hairgrass could compete with Kentucky bluegrass in the absence of grazing, but it appears that once Kentucky bluegrass is established it remains to form a stable community type.

\section{Plant Composition Canopy Cover(\%) MEAN RANGE CONST.}

\section{SHRUBS}

SHRUBBY CINQUEFOIL

(Potentilla fruticosa) $2 \quad 0-3 \quad 50$

WILLOW

(Salix spp.) $\quad 4 \quad 0-7 \quad 50$

FORBS

DANDELION

(Taraxacum officinale) $\quad 7 \quad 1-14 \quad 100$

STICKY PURPLE GERANIUM

(Geranium viscosissmum) $2 \quad 0-3 \quad 50$

STRAWBERRY

(Fragaria virginiana) $1 \quad 0-2 \quad 50$

GRACEFUL CINQUEFOIL

$\begin{array}{llll}\text { (Potentilla gracilis) } & 5 & 0-9 & 50\end{array}$

YARROW

$\begin{array}{llll}\text { (Achillea millefolium) } & 5 & 1-10 & 100\end{array}$

GRASSES

KENTUCKY BLUEGRASS

(Poa pratensis)
SLENDER WHEATGRASS

(Agropyron trachycaulum) $3 \quad 1-4 \quad 100$

TUFTED HAIRGRASS

(Deschampsia cespitosa) $54 \quad 49-59 \quad 100$

SEDGE

$\begin{array}{llll}\text { (Carex spp..) } & 1 & 0-1 & 50\end{array}$

\section{ENVIRONMENTAL VARIABLES}

MOISTURE REGIME:

SUBHYGRIC

NUTRIENT REGIME:

PERMESOTROPHIC

ELEVATION:

1585(1440-1730)M

SOIL DRAINAGE:

MODERATELY WELL

ASPECT:

VARIABLE

SLOPE:

$4(3-5) \%$

ECOLOGICAL STATUS SCORE: 24 OR 16

\section{FORAGE PRODUCTION(KG/HA)}

GRASS: 2792(2088-3496)

FORBS: $\quad 405(262-548)$

TOTAL: $\quad 3197(2350-4044)$

ECOLOGICALLY SUSTAINABLE STOCKING RATE $0.9(1.2-0.7)) \mathrm{HA} / \mathrm{AUM}$ OR $0.45(0.33-0.57) \mathrm{AUM} / \mathrm{AC}$ 


\section{SASMC11. Creeping red fescue/Clover (Festuca rubra/Trifolium repens)}

$\mathbf{n}=\mathbf{3} \quad$ This community type represents old range improvement sites in the North Sheep allotment. These sites were developed by clearing, breaking and seeding selected aspen dominated community types throughout the allotment. These sites are highly productive and should be rated as primary range. In the absence of disturbance these community types will likely succeed back to aspen. Community SASMC12 represents the early stages of this successional sequence.

\section{Plant Composition CanopyCover(\%)} MEAN RANGe Const.

SHRUBS

ROSE

(Rosa acicularis)

FORBS

DANDELION

(Taraxacum officinale)

Clover

(Trifolium repens)

STRAWBERRY

(Fragaria virginiana)

PEAvine

(Lathyrus ochroleucus)

GRASSES

CREEPING RED FESCUE

(Festuca rubra)

ORCHARDGRASS

(Dactylis glomeraza)

PINEGRASS

(Calamagrostis rubescens)3

TIMOTHY

(Phleum pratense)
$1 \quad 1-2 \quad 100$

$2 \quad 1-3 \quad 100$

$17 \quad 8-33 \quad 100$

$4 \quad 3-6 \quad 100$

$2 \quad 0-4 \quad 66$

$47 \quad 29-68 \quad 100$

$7 \quad 1-13 \quad 100$

$1-5 \quad 100$

$0-3 \quad 66$

\section{ENVIRONMENTAL VARIABLES}

MOISTURE REGIME:

MESIC

NUTRIENT REGIME: MESOTROPHIC

ELEVATION: 1488(1488-1505)M

SOIL DRAINAGE:

WELL

ASPECT:

SOUTHERLY

SLOPE:

$17(10-20)) \%$

ECOLOGICAL STATUS SCORE: TAME PASTURE

\section{FORAGE PRODUCTION(KG/HA)}

GRASS: $\quad 1916$

FORBS: 152

SHRUBS $\quad 52$

TOTAL: $\quad 2120$

ECOLOGICALLY SUSTAINABLE STOCKING RATE $0.5(0.8-0.4) \mathrm{HA} / \mathrm{AUM}$ $0.8(0.5-1.01) \mathrm{AUM} / \mathrm{AC}$ 


\section{SASMC12. Rose/Pinegrass \\ (Rosa acicularis/Calamagrostis rubescens)}

$\mathbf{n}=\mathbf{1}$ This community type represents an old range improvement site that is slowly succeeding back to an aspen dominated forest. In the absence of disturbance native species such as rose, aspen and pinegrass will slowly encroach onto these old tame pastures.

\section{Plant Compositioncanopy Cover(\%)} MEAN RANGe Const.

\section{SHRUBS}

ROSE

(Rosa acicularis)

$13 \quad-\quad 100$

SNOWBERRY

(Symphoricarpos

occidentalis)

$4 \quad-\quad 100$

FORBS

WILD BERGAMONT

(Monarda fistulosa)

STICKY PURPLE GERANIUM

(Geranium viscosissmum) 9

STRAWBERRY

$\begin{array}{llll}\text { (Fragaria virginiana) } & 3 & - & 100\end{array}$

AMERICAN VETCH

(Vicia americana)

SMOOTH ASTER

(Aster laevis)

GRASSES

SMOOTH WILDRYE

(Elymus glaucus)

PINEGRASS

(Calamagrostis rubescens)7

SMOOTH BROME

(Bromus inermis)

CREEPING RED FESCUE

(Festuca rubra)

$7 \quad-\quad 100$

$6 \quad-\quad 100$

$10 \quad-\quad 100$

100

100

100

\section{ENVIRONMENTAL VARIABLES}

MOISTURE REGIME:

MESIC

NUTRIENT REGIME:

MESOTROPHIC

ELEVATION:

$1590 \mathrm{M}$

SOIL DRAINAGE:

WELL

ASPECT:

SOUTHERLY

SLOPE:

$30 \%$

ECOLOGICAL STATUS SCORE: TAME PASTURE

FORAGE PRODUCTION(KG/HA)

GRASS: $\quad 444$

FORBS: $\quad 452$

SHRUB $\quad 120$

TOTAL: 1016

ECOLOGICALLY SUSTAINABLE STOCKING RATE

$1.0(1.2-0.8) \mathrm{HA} / \mathrm{AUM}$

$0.4(.33-0.5) \mathrm{AUM} / \mathrm{AC}$ 


\section{SASMC13. Idaho fescue-Sheep fescue-Canada bluegrass \\ (Festuca idahoensis-Festuca saximontant-Poa compressa)}

$\mathbf{n}=\mathbf{1}$ This community type represents a heavily grazed, gravelly river flat adjacent to Pekisko Creek. In the absence of disturbance this plant community will likely be dominated by rough and Idaho fescue. As one moves up in elevation from the Montane to the Subalpine thereis a shift away from a Rough fescue-Parry oatgrass dominated community type to a Rough fescue Sedge dominatedcommunity type. Jaques (1976), described a Rough fescue-Sedge dominated community type from Plateau Mountain to Mount Allan. He felt thiscommunity type represented critical wildlife habitat because it remained snow-free for a majority of the winter. Grazing by livestock on these community types should be managed carefully in order to maintain a carryover for wildlife in the winter.

\section{Plant Compositioncanopy Cover(\%) \\ Mean Range Const.}

SHRUBS

RosE

(Rosa acicularis)

7

SASKATOON

(Amelanchier alnifolia)

2

FORBS

WILD BERGAMONT

(Monarda fistulosa)

5

STICKY PURPLE GERANIUM

(Geranium viscosissmum) 7

SHOWY LOCOWEED

(Oxytropis splendens)

Missouri Goldenrod

(Solidago missouriensis) 15

GRASSES

IDAHO FESCUE

(Festuca idahoensis)

Sheep fescue

(Festuca saximontant)

TімотнY

(Phleum pratense)

CANADA BLUEGRASS

(Poa compressa)
100

100

100

100

100

100

$15 \quad-\quad 100$

$30 \quad-\quad 100$

$10 \quad-\quad 100$

$15 \quad-\quad 100$

\section{ENVIRONMENTAL VARIABLES}

MOISTURE REGIME:

MESIC TO SUBMESIC

NUTRIENT REGIME: MESOTROPHIC

ELEVATION:

$1488 \mathrm{M}$

SOIL DRAINAGE:

WELL

ASPECT:

VARIABLE

SLOPE:

$2 \%$

ECOLOGICAL STATUS SCORE: 8

FORAGE PRODUCTION(KG/HA)

TOTAL: $\quad 1500$

ECOLOGICALLY SUSTAINABLE STOCKING RATE

1.0(1.2-0.5) HA/AUM

$0.4(.33-0.8) \mathrm{AUM} / \mathrm{AC}$ 


\section{SUBALPINE SUBREGION}

\section{SOUTHERN ECODISTRICTS}

\section{FORESTED COMMUNITY TYPES}

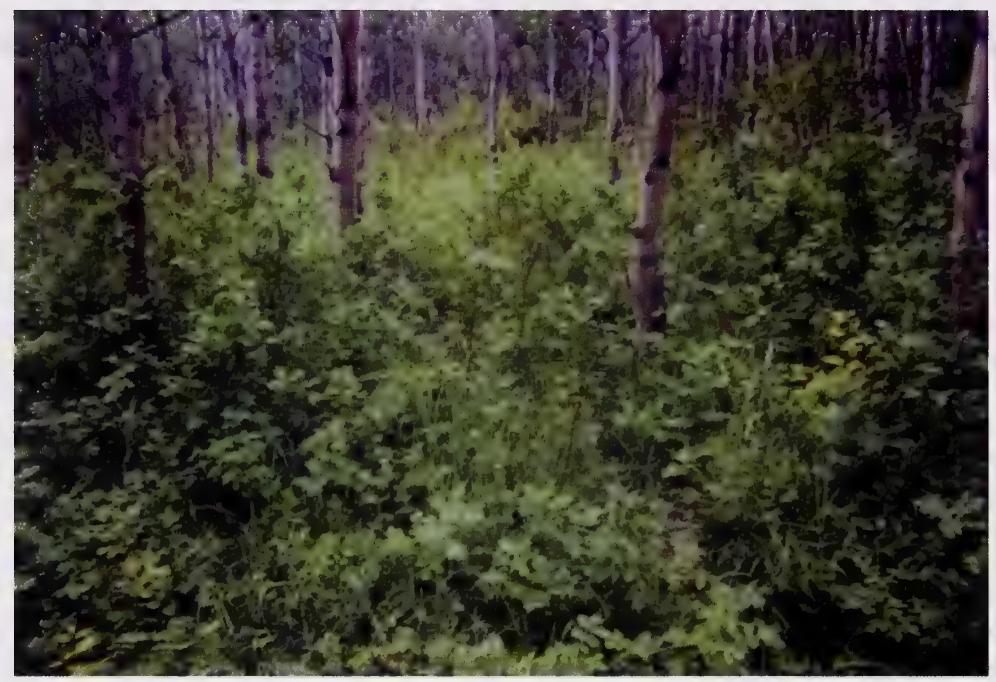

Figure 8. Deciduous communities are not common in the Subalpine, but where they do occur they can be very productive for domestic livestock. This picture represents an Aspen/Rose/Pinegrass dominated community, which can be common on warmer sites in the Subalpine subregion of southern Alberta. 


\section{SUBALPINE SUBREGION}

\section{FOREST ECOLOGY}

The forested plant communities in the subalpine can be split into three zones. These include the Pine, Spruce-Fir and Upper Subalpine zones (Strong and Leggat 1992). The Pine zone is the lowest elevation zone and is dominated by lodgepole pine and shows little evidence of succession to Engelmann spruce. It is within this zone that aspen and balsam poplar dominated plant communities can occur on warmer sites. The Spruce-Fir zone is located altitudinally above the Pine zone (Strong and Leggat 1992). This zone displays evidence of lodgepole pine succession to Engelmann spruce and subalpine fir. The Upper subalpine zone is characterized by open canopied vegetation that occurs between the Spruce-Fir zone and timberline. This zone is dominated by dwarfed Engelmann spruce, alpine fir, whitebark pine and alpine larch. Plant growth in this upper zone is limited by low temperatures, wind, low moisture and a short growing season (Strong and Leggat 1992). There are only a handful of forested community types described in this guide. Archibald et al. (1996), provide a good descriptions of the major forested community types in the Subalpine subregion that are not represented in this guide. Generally, these forested plant communities only provide limited forage for domestic livestock, but where deciduous communities are extensive they can be heavily utilized by livestock and should be considered secondary range. 
Table 6. Deciduous and conifer communities of the Southern Rocky Mountains of the Subalpine subregion

\begin{tabular}{|c|c|c|c|c|c|c|c|c|}
\hline \multirow{2}{*}{$\begin{array}{l}\text { Community } \\
\text { number }\end{array}$} & \multirow[t]{2}{*}{ Community type } & \multirow[b]{2}{*}{ Grass } & \multicolumn{3}{|c|}{ Productivity (kg/ha) } & \multirow[b]{2}{*}{ Moisture } & \multirow[b]{2}{*}{ Drainage } & \multirow{2}{*}{$\begin{array}{l}\text { Carrying } \\
\text { capacity (ha/AUM) }\end{array}$} \\
\hline & & & Forb & Shrub & Total & & & \\
\hline a1 & lichen PI & - & - & - & - & Submesic & Rapidly & 3.0 \\
\hline SASME1 & Pl/Juniper & - & - & - & - & Submesic & Rapidly & 3.0 \\
\hline e1 & false azalea-grouseberry PI & 199 & 444 & 121 & 727 & Mesic & Well & 4.5 \\
\hline SASME2 & $\mathrm{Pl} /$ Pinegrass & 210 & 180 & 154 & 472 & Mesic & Well & 4.9 \\
\hline SASME3 & Pl-Se/Moss & 187 & 707 & 88 & 981 & Mesic & Well & 3.0 \\
\hline e3 & false azalea-grouseberry Se & & & & $155^{*}$ & Mesic & Well & 5.9 \\
\hline SASME4 & Sw-Aw/Alder/Hairy wildrye & & & & $155^{*}$ & Mesic & Well & 5.9 \\
\hline e5 & deciduous & 900 & 438 & 83 & 1388 & Mesic & Well & 1.5 \\
\hline SASMD1 & $\mathrm{Pb} /$ Silverberry & - & - & - & $444^{*}$ & Submesic & Rapidly & 4.0 \\
\hline SASMD2 & Aw/Rose/Pinegrass & 641 & 535 & 113 & 1210 & Mesic & Well & 1.5 \\
\hline SASMD9 & Aw/Rose/Marsh reedgrass & 1208 & 292 & 64 & 1564 & Mesic & Well & 1.2 \\
\hline e5a & grazed deciduous & 1113 & 441 & 57 & 1611 & Mesic & Well & 1.5 \\
\hline SASMD3 & Aw/Fireweed/Meadow foxtail & 1612 & 679 & 92 & 2383 & Mesic & Well & 1.0 \\
\hline SASMD4 & Aw/Rose/Canada bluegrass & 1036 & 348 & 78 & 1462 & Submesic & Well & 1.4 \\
\hline SASMD8 & Aw/Kentucky bluegrass/Clover & 692 & 296 & - & 988 & Mesic & Well & 1.5 \\
\hline f3 & thimbleberry Aw-Pb & 585 & 796 & 350 & 1731 & Subhygric & Well & 1.3 \\
\hline SASMD5 & Aw-Pb/Cow parsnip & 328 & 1200 & 92 & 1620 & Subhygric & Well & 1.3 \\
\hline SASMD7 & $\mathrm{Pb} /$ Willow/Marsh reedgrass & 842 & 392 & 608 & 1842 & Subhygric & Well & 1.1 \\
\hline f3a & grazed thimbleberry $\mathbf{A w}-\mathbf{P b}$ & 328 & 1200 & 92 & 1620 & Subhygric & Well & 1.3 \\
\hline SASMD6 & $\mathrm{Aw}-\mathrm{Pb} / \mathrm{Cow}$ parsnip/Timothy & 328 & 1200 & 92 & 1620 & Subhygric & Well & 1.3 \\
\hline i3 & treed fen & 266 & 44 & 492 & 808 & Subhygric & Poorly & 40.0 \\
\hline SASME5 & Sw/Willow-Labrador tea & 266 & 44 & 492 & 808 & Subhygric & Poorly & 40.0 \\
\hline
\end{tabular}

\footnotetext{
*Estimate
} 


\section{SASMD1. Pb/Silverberry \\ (Populus balsamifera/Elaeagnus commutata)}

$\mathbf{n = 1}$ This community type was described along the banks of Pekisko creek in the Pekisko Creek allotment. It is characteristic of dry gravelly, river flats, which are periodically flooded in the spring. This community type is very similar to the yellow mountain avens community which have been described in both the Montane and Subalpine subregions.

Generally, there is little forage for domestic livestock in this community type and it should be rated as nonuse.

\section{Plant Composition Canopy Cover(\%)} Mean Range Const.

TREES

BALSAM POPLAR

(Populus balsamifera)

15

100

\section{SHRUBS}

PRICKLY ROSE

(Rosa acicularis)

SILVERBERRY

(Elaeagnus commutata)

SHRUBBY CINQUEFOIL

(Potentilla fruticosa)

FALSE MOUNTAIN WILLOW

(Salix pseudomonticola) 2

\section{FORBS}

ALPINE HEDYSARUM

(Hedysarum alpinum)

COMMON HORSETAIL

(Equisetum arvense)

CUT-LEAVED ANEMONE

(Anemone multifida)

GRACEFUL CINQUEFOIL

(Potentilla gracilis)

1
5
1
2

100

100

100

100

\section{Grasses}

BLUE BUNCH WHEATGRASS

(Agropyron spicatum)

JUNE GRASS

(Koeleria macrantha)

CANADA BLUEGRASS

(Poa compressa)

HAIRY WILD RYE

(Elymus innovatus)

\section{ENVIRONMENTAL VARIABLES}

\section{MOISTURE REGIME :}

SUBMESIC

NUTRIENT REGIME :

MESOTROPHIC

ELEVATION:

$1828 \mathrm{M}$

SOIL DRAINAGE :

RAPIDLY

SLOPE:

$18 \%$

ASPECT:

SOUTHEAST

ECOLOGICAL STATUS SCORE: 18

Forage Production Kg/HA

Total 444 *ESTIMATE
ECOLOGICALLY SUSTAINABLE STOCKING RATE GENERALLY NON-USE 4.0(4.0-2.0) HA/AUM OR $0.1(0.1-0.2) \mathrm{AUM} / \mathrm{AC}$ 


\section{SASMD2. Aw/Rose/Pinegrass \\ (Populus tremuloides/Rosa/Calamagrostis rubescens)}

$\mathbf{n}=\mathbf{2 9}$ This community type is similar to the Aw/Rose/Pinegrass community which is described on mesic sites with medium nutrient regimes in the Montane subregion. It may represent the transition from the Montane to the Subalpine. These sites were described at lower elevations in the Subalpine and generally had southerly aspects, making the conditions more suitable for growing aspen. The forage productivity on this community type is moderate and it should be rated as secondary range.

Plant COMPOSITION CANOPY COVER(\%)

TreEs Mean Range Const.

\section{ASPEN}

\begin{tabular}{llll}
$\begin{array}{l}\text { (Populus tremuloides) } \\
\begin{array}{l}\text { WHITE SPRUCE } \\
\text { (Picea glauca) }\end{array}\end{array}$ & 42 & $20-80$ & 100 \\
$\begin{array}{l}\text { BALSAM POPULAR } \\
\text { (Populus balsamifera) }\end{array}$ & 2 & $0-5$ & 44 \\
\hline
\end{tabular}

\section{SHRUBS}

PRICKLY ROSE

$\begin{array}{llll}\text { (Rosa acicularis) } & 7 & 1-28 & 100\end{array}$

SNOWBERRY

(Symphoricarpos albus) $2 \quad 0-5 \quad 49$

WHITE MEADOWSWEET

(Spiraea betulifolia) $3 \quad 0-31 \quad 45$

WILD RED RASPBERRY

(Rubus idaeus)

$1 \quad 0-8 \quad 38$

\section{FORBS}

WILD VETCH

(Vicia americana) 4
CREAM COLORED VETCHLING

(Lathyrus ochroleucus) 6

WILD STRAWBERRY

$\begin{array}{llll}\text { (Fragaria virginiana) } & 5 & 0-11 \quad 97\end{array}$

SHOWY ASTER

(Aster conspicuus)

COMMON FIREWEED

(Epilobium angustifolium)5

COMMON DANDELION

(Taraxacum officinale) 1

WESTERN CANADIAN VIOLET

(Viola canadensis)

2

PINEGRASS

(Calamagrostis rubescens) $14 \quad 3-32 \quad 100$

HAIRY WILDRYE

(Elymus innovatus) $\quad 6 \quad 0-14 \quad 86$

\section{ENVIRONMENTAL VARIABLES}

MOISTURE REGIME :

SUBMESIC TO SUBHYGRIC

NUTRIENT REGIME :

MESOTROPHIC

ELEVATION:

$$
\text { 1608(1400-1768)M }
$$

SOIL DRAINAGE :

WELL TO IMPERFECTLY

SLOPE:

$$
15(6-30) \%
$$

ASPECT:

SOUTHERLY

ECOLOGICAL STATUS SCORE: 18

\section{Forage Production Kg/HA}

GRASS 641(160-1512)

FORB 535(44-1151)

SHRUB 113(0-726)

TOTAL 1210(416-2034)

\section{GRASSES}

ECOLOGICALLY SUSTAINABLE STOCKING RATE $1.5(4.4-0.9) \mathrm{HA} / \mathrm{AUM}$ $0.27(0.09-0.45)$ AUM/AC 


\section{SASMD3. Aw/Fireweed/Meadow foxtail \\ (Populus tremuloides/Epilobium angustifolium/Alopecurus pratensis)}

$\mathbf{n}=1 \quad$ This community type was described in the South Sheep allotment on an old range improvement area. Many aspen stands in the South Sheep were cleared and seeded to mixture of brome, meadow foxtail, creeping red fescue and clover. This site represents invasion of aspen back into these range improvement areas. Meadow foxtail is generally unpalatable to livestock and has persisted on these sites.

This community is very productive and efforts should be made to control the aspen invasion.

Plant Composition Canopy Cover(\%) MEAN RANGe Const.

TREES

ASPEN

(Populus tremuloides)

36

100

SHRUBS

PRICKLY ROSE

(Rosa acicularis)

PIN CHERRY

(Prunus pensylvanica)

$8 \quad-\quad 100$

100

FORBS

COMMON FIREWEED

(Epilobium angustifolium) 12

STICKY PURPLE GERANIUM

(Geranium viscosissimum) $8 \quad-\quad 100$

LINDLEY'S ASTER

(Aster ciliolatus)

COMMON VETCH

(Vicia americana) 3

CREAM COLORED VETCHLING

(Lathyrus ochroleucus) 2

\section{Grasses}

MEADOW FOXTAIL

$\begin{array}{llll}\text { (Alopecurus pratensis) } & 32 \quad-\quad 100\end{array}$

ORCHARDGRASS

(Dactylis glomerata)

KENTUCKY BLUEGRASS

(Poa pratensis)

17

Тімотну

(Phleum pratense)

$3 \quad-\quad 100$

$7 \quad-\quad 100$
100

100

\section{ENVIRONMENTAL VARIABLES}

MOISTURE REGIME :

MESIC TO SUBHYGRIC

NUTRIENT REGIME :

MESOTROPHIC

ELEVATION:

$1400 \mathrm{M}$

SOIL DRAINAGE :

WELL

SLOPE:

$10 \%$

ASPECT:

SOUTHWEST

ECOLOGICAL STATUS SCORE: TAME PASTURE

Forage Production Kg/HA

GRASS 1612

FORB 679

SHRUB 92

TOTAL 2383
ECOLOGICALLY SUSTAINABLE STOCKING RATE $1.0(1.5-0.8) \mathrm{HA} / \mathrm{AUM}$ or $0.4(0.26-0.5)$ AUM/AC 


\section{SASMD4. Aw/Rose/Canada bluegrass \\ (Populus tremuloides/Rosa spp./Poa compressa)}

$\mathbf{n}=\mathbf{1}$ This community type represents a Aw/Rose/Pinegrass community that has been heavily grazed and invaded by Canada bluegrass. Canada bluegrass is an introduced grass that increases with increased grazing pressure. As grazing pressure increases in these aspen dominated community types there is a shift away from native species (rose, pinegrass, asters, fireweed) to a community that is dominated by bluegrass, timothy, dandelion and clover species. The invasion of non-native invaders onto the site makes this community very productive for domestic livestock, but the presence of overgrazed communities indicates some type of distribution problem and the management of the disposition should be discussed.

\section{Plant Composition Canopy Cover(\%)} Mean Range Const.

TREES

ASPEN

$$
\text { (Populus tremuloides) }
$$$$
35
$$

WHITE SPRUCE

(Picea glauca)

$$
5
$$

\section{SHRUBS}

PRICKLY Rose

(Rosa acicularis)

WILD RED RASPBERRY

(Rubus idaeus)

NORTHERN GOOSEBERRY

(Ribes oxyacanthoides)

\section{FORBS}

LINDLEY'S ASTER

(Aster ciliolatus)

WILD STRAWBERRY

(Fragaria virginiana)

COMMON DANDYLION

(Taraxacum officinal)

COMMON FIREWEED

(Epilobium angustifolium) 4

CREAM COLORED VETCHLING

(Lathyrus ochroleucus) 4

GraSSES

CANADA BLUEGRASS

(Poa compressa)

PINE REEDGRASS

(Calamagrostis rubescens) $9 \quad-\quad 100$

HAIRY WILDRYE

(Elymus innovatus) $\quad 9 \quad-\quad 100$

AWNLESS BROME

(Bromus inermis)

\section{ENVIRONMENTAL VARIABLES}

MOISTURE REGIME :

SUBMESIC

NUTRIENT REGIME :

MESOTROPHIC

ELEVATION:

$$
1420 \mathrm{M}
$$

SOIL DRAINAGE :

WELL

SLOPE:

$$
10 \%
$$

ASPECT:

SOUTHWEST

ECOLOGICAL STATUS SCORE: 6

\section{Forage Production Kg/HA}

$\begin{array}{ll}\text { GRASS } & 1036 \\ \text { FORB } & 348 \\ \text { SHRUB } & 78 \\ \text { TOTAL } & 1462\end{array}$

ECOLOGICALLY SUSTAINABLE STOCKING RATE 1.4(1.8-1.2) HA/AUM or $0.28(0.22-0.33) \mathrm{AUM} / \mathrm{AC}$ 


\section{SASMD5. Aw-Pb/Cow parsnip \\ (Populus tremuloides-Populus balsamifera/Heracleum lanatum)}

$\mathbf{n}=\mathbf{3}$ Nutrient seepage occurs at some point in the growing season favouring the growth of cow parsnip. This community type is very similar to the Aw/Thimbleberry community described in the Montane subregion. Forage productivity on these sites is generally quite hig because of the favourable moisture and nutrient conditions. Cow parsnip is palatable to livestock and maybe extensively utilized. This community type should be rated as secondary range.

\section{Plant COMPOSITION CANOPY COVER(\%) Mean Range Const.}

TREES

ASPEN

$\begin{array}{cccc}\begin{array}{c}\text { (Populus tremuloides) } \\ \text { BALSAM POPLAR } \\ \text { (Populus balsamifera) }\end{array} & 17 & 0-30 & 67 \\ & 18 & 10-30 & 100\end{array}$

\section{SHRUBS}

WILD RED RASPBERRY

$\begin{array}{llll}\text { (Rubus idaeus) } & 1 & 0-1 & 67 \\ \text { NORTHERN GOOSEBERRY } & & & \end{array}$

(Ribes oxyacanthoides) $2 \quad 0-5 \quad 33$

FORBS

CREAM COLORED VETCHLING

(Lathyrus ochroleucus) 5

COW PARSNIP

(Heracleum lanatum) $\quad 31 \quad 8-48 \quad 100$

LINDLEY'S ASTER

(Aster ciliolatus)

WESTERNCANADA VIOLET

(Viola canadensis)

TALL LUNGWORT

(Mertensia paniculata) 5

TALL LARKSPUR

(Delphinium glaucum) 5

COMMON FIREWEED

(Epilobium angustifolium) 4

COMMON DANDYLION

(Taraxacum officinale) 2

\section{Grasses}

MARSH REEDGRASS

(Calamagrostis canadensis) $4 \quad 0-7 \quad 67$

HAIRY WILDRYE

(Elymus innovatus)

AWNLESS BROME

(Bromus inermis)

$2 \quad 1-2 \quad 100$

TIMOTHY

$\begin{array}{llll}\begin{array}{l}\text { (Phleum pratense) } \\ \text { SEDGE }\end{array} & 2 & 1-3 & 100 \\ \text { (Carex spp.) } & 1 & 1-2 & 100\end{array}$

\section{ENVIRONMENTAL VARIABLES}

MOISTURE REGIME :

SUBHYGRIC

NUTRIENT REGIME :

ELEVATION:

MESOTROPHIC-PERMESOTROPHIC

$1400 \mathrm{M}$

SoIL DRAINAGE :

WELL

SLOPE:

ASPECT:

$8 \%$

SOUTHWEST

ECOLOGICAL STATUS SCORE: 18

\section{Forage Production Kg/HA}

$\begin{array}{ll}\text { GRASS } & 328 \\ \text { FORB } & 1200 \\ \text { SHRUB } & 92 \\ \text { TOTAL } & 1620\end{array}$

ECOLOGICALLY SUSTAINABLE STOCKING RATE $1.3(2.0-1.0) \mathrm{HA} / \mathrm{AUM}$ OR $0.31(0.2-0.4) \mathrm{AUM} / \mathrm{AC}$ 


\section{SASMD6. Aw-Pb/Cow parsnip/Timothy (Populus tremuloides-Populus balsamifera/Heracleum lanatum/Phleum pratense)}

$\mathbf{n = 1} \quad$ Nutrient seepage occurs at some point in the growing season favouring the growth of cow parsnip. This community type is very similar to the previously described $\mathrm{Aw}-\mathrm{Pb} / \mathrm{Cow}$ parsnip community, but this community has a high cover of timothy. Increased grazing pressure will often allow timothy, Kentucky bluegrass and dandelion to invade onto these sites. Forage productivity on these sites is generally quite high because of the favourable moisture and nutrient conditions. Cow parsnip is palatable to livestock and maybe extensively utilized. This community type should be rated as secondary range.

Plant Composition Canopy Cover(\%) Mean Range Const.

TREES

ASPEN

$\begin{array}{llll}\begin{array}{c}\text { (Populus tremuloides) } \\ \text { BALSAM POPLAR }\end{array} & 26 & - & 100 \\ \text { (Populus balsamifera) } & 16 & - & 100\end{array}$

\section{SHRUBS}

WILD RED RASPBERRY

(Rubus idaeus)

\section{FORBS}

CREAM COLORED VETCHLING

(Lathyrus ochroleucus) 2

COW PARSNIP

(Heracleum lanatum) 2

LINDLEY'S ASTER

(Aster ciliolatus)

WESTERNCANADA VIOLET

(Viola canadensis)

TALL LUNGWORT

(Mertensia paniculata)

WESTERN MEADOW RUE

(Thalictrum occidentalis) 4

COMMON FIREWEED

(Epilobium angustifolium)1 - 100

COMMON DANDELION

$\begin{array}{lll}\text { (Taraxacum officinale) } & 6 & -\end{array}$

\section{GRASSES}

MARSH REEDGRASS

(Calamagrostis rubescens) 4

SMOOTH WILDRYE

(Elymus glaucus)

AWNLESS BROME

(Bromus inermis)

TIMOTHY

(Phleum pratense)
SEDGE

(Carex spp.)

3

100

\section{ENVIRONMENTAL VARIABLES}

MOISTURE REGIME :

SUBHYGRIC

NUTRIENT REGIME :

PERMESOTROPHIC

ELEVATION:

$1510 \mathrm{M}$

SOIL DRAINAGE :

MOD. WELL

SLOPE:

$10 \%$

ASPECT:

VARIABLE

ECOLOGICAL STATUS SCORE: 12

\section{Forage Production Kg/HA}

GRASS 328

FORB 1200

SHRUB 92

TOTAL 1620

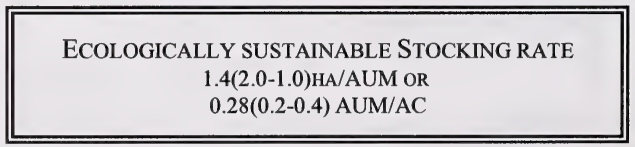




\section{SASMD7. Balsam poplar/ Willow/ Marsh reedgrass \\ (Populus balsamifera/ Salix spp/Calamagrostis canadensis)}

$\mathbf{n = 1}$ This community type was described on the flood plain adjacent to a creek. This community is not common in the Subalpine subregion and likely represents the continued succession of a willow dominated community type. Continued succession in the absence of disturbance will likely lead to the development of a spruce dominated community type.

. When in close proximity to primary range areas this community type should be rated as secondary range.

Plant Composition Canopy Cover(\%) Mean Range Const.

\section{TREES}

BALSAM POPLAR

(Populus balsamifera)

LODGEPOLE PINE

(Pinus contorta)

SHRUBS

BOG BIRCH

(Betula glandulosa)

WILLOW

(Salix spp.)

FORBS

HORSETAIL

(Equisetum arvense)

LINDLEY'S ASTER

(Aster ciliolatus)

RICHARDSON GERANIUM

(Geranium richardsonii)

FIREWEED

(Epilobium angustifolium) 3

STRAWBERRY

(Fragaria virginiana)

$20 \quad-\quad 100$

$4 \quad-\quad 100$

(10)

$2 \quad-\quad 100$

$13 \quad-\quad 100$

\section{Grasses}

MARSH REEDGRASS

(Calamagrostis canadensis)

KENTUCKY BLUEGRASS

(Poa pratensis)
$15 \quad-\quad 100$

$4 \quad-\quad 100$

\section{ENVIRONMENTAL VARIABLES}

MOISTURE REGIME:

SUBHYGRIC

NutRIENT REgIME:

ELEVATION:

PERMESOTROPHIC

$1656 \mathrm{M}$

SOIL DRAINAGE:

MODERATELY WELL

ECOLOGICAL STATUS SCORE: 18

FORAGE PRODUCTION(KG/HA)

GRASS: 842

FORBS: 392

SHRUBS: 608

TOTAL: 1842

ECOLOGICALLY SUSTAINABLE STOCKING RATE

$1.1(2.0-1.0) \mathrm{HA} / \mathrm{AUM}$ OR

$0.36(0.2-0.4) \mathrm{AUM} / \mathrm{AC}$ 


\section{SASMD8. Aw/Kentucky bluegrass/Clover (Populus tremuloides/Poa pratensis/Trifolium spp.)}

$\mathbf{n}=\mathbf{1}$ This community type is representative of an Aw/Rose/Pinegrass or Marsh reedgrass community type that has recieved prolonged heavy grazing. This type often occurs in relatively small isolated patches created by intensive grazing adjacent to water, salt or temporary holding areas. The species richness and diversity of native grass, forbs and shrubs is reduced and replaced by grazing resistant clover, dandelion and Kentucky bluegrass. This community type would be rated as unhealthy and distribution of livestock throughout the disposition should be examined.

\section{Plant Composition Canopy Cover(\%)} Mean Range Const.

TREES

\section{ASPEN}

(Populus tremuloides)

WHITE SPRUCE

(Picea glauca)

SHRUBS

ROSE

(Rosa acicularis)

BRISTLY BLACK CURRANT

(Ribes lacustre.)

FORBS

CLOVER

(Trifolium repens)

LINDLEY'S ASTER

(Aster ciliolatus)

DANDELION

(Taraxacum officinale)

BUNCHBERRY

(Cornus canadensis)

STRAWBERRY

(Fragaria virginiana)

\section{Grasses}

MARSH REEDGRASS

(Calamagrostis canadensis)

KENTUCKY BLUEGRASS

(Poa pratensis)

TIMOTHY

(Phleum pratense)
27

$\begin{array}{lll}61 & - & 100 \\ 1 & - & 100\end{array}$

$3-100$

$2 \quad-\quad 100$

100

100

100

100

100

16

$14 \quad-\quad 100$

$10 \quad-\quad 100$

$5-100$

\section{ENVIRONMENTAL VARIABLES}

MOISTURE REGIME:

MESIC

NUTRIENT REGIME:

MESOTROPHIC

ELEVATION:

$1410 \mathrm{M}$

SOIL DRAINAGE:

WELL

ECOLOGICAL STATUS SCORE: 0

FORAGE PRODUCTION(KG/HA)

GRASS: 692

FORBS: 296

SHRUBS: -

TOTAL: 988

ECOLOGICALLY SUSTAINABLE STOCKING RATE

$1.5(1.9-1.3) \mathrm{HA} / \mathrm{AUM}$ OR

$0.26(0.21-0.3) \mathrm{AUM} / \mathrm{AC}$ 


\section{SASMD9. Aw/Rose/Marsh reedgrass \\ (Populus tremuloides/Rosa acicularis/Calamagrostis canadensis)}

$\mathbf{n}=\mathbf{1}$ This community type is similar to the Aw/Rose/Pinegrass dominated community type, but occupies slightly moister sites which favours the growth of marsh reedgrass over pinegrass. Marsh reedgrass is not common in the Subalpine or the lower Montane subregions and the presence of this species likely indicates a boreal climatic influence on the site. This community type has a low shrub cover and extensive cover of grass which makes it fairly attractive to livestock. In the northern half of the province this community type is often heavily utilized.

\section{Plant Composition Canopy Cover(\%)} Mean Range Const.

\section{TREES}

\section{ASPEN}

(Populus tremuloides)

WHITE SPRUCE

(Picea glauca)

SHRUBS

RosE

(Rosa acicularis)

SNOWBERRY

(Symphoricarpos

\section{FORBS}

$$
\text { occidentalis) }
$$

9

RICHARDSON'S GERANIUM

(Geranium richardsonii) 8

LINDLEY'S ASTER

(Aster ciliolatus)

YELLOW PEAVINE

(Lathyrus ochroleucus)

VEINY MEADOW RUE

(Thalictrum venulosum) 7

SHOWY ASTER

(Aster conspicuus)

\section{GRASSES}

MARSH REEDGRASS

(Calamagrostis

$$
\text { canadensis) }
$$

SLENDER WHEATGRASS

(Agropyron trachycaulum)7

HAIRY WILDRYE

(Elymus innovatus)
65

7

$-\quad 100$

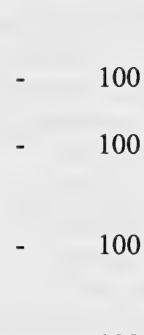

3

8

$-\quad 100$

$6-100$

$8 \quad-\quad 100$

$5 \quad-\quad 100$

$-\quad 100$
$-\quad 100$
$-\quad 100$

$7 \quad-\quad 100$

\section{ENVIRONMENTAL VARIABLES}

MOISTURE REGIME:

SUBHYGRIC

NUTRIENT REGIME:

MESOTROPHIC

ELEVATION:

$1400 \mathrm{M}$

SOIL DRAINAGE:

WELL

SLOPE: $20 \%$

ASPECT: WESTERLY

ECOLOGICAL STATUS SCORE: 18

FORAGE PRODUCTION(KG/HA)

GRASS: 1208

FORBS: 292

SHRUBS: 64

TOTAL: 1564

ECOLOGICALLY SUSTAINABLE STOCKING RATE

$1.3(4.0-1.0) \mathrm{HA} / \mathrm{AUM}$ OR $0.1(0.1-0.4) \mathrm{AUM} / \mathrm{AC}$ 


\section{SASMD10. Aw/Bearberry-Juniper (Populus tremuloides/Arctostaphylos uva-ursi-Juniperus horizontalis)}

$\mathbf{n = 1} \quad$ This community type occupies dry, upper slope and hilltop positions and represents the invasion of aspen onto a Juniper, Bearberry-dominated grassland. The soils on this community type are fairly well developed and the moisture conditions are high enough to favour the growth of aspen. In years of drought aspen will likely die back in this community type. Frequent fire also tends to control the spread of aspen onto these shrub dominated grasslands. The lack of fire in the last 50 years has allowed many of these grasslands to be invaded by aspen.

\section{Plant CoMposition Canopy Cover(\%)} Mean Range Const.

\section{TREES}

ASPEN

(Populus tremuloides)

LODGEPOLE PINE

(Pinus contorta)

SHRUBS

CANADA BUFFALOBERRY

(Shepherdia canadensis) 8

CREEPING JUNIPER

(Juniperus horizontalis) 5

FORBS

BEARBERRY

(Arctostaphylos uva-ursi) 40

YELLOW HEDYSARUM

(Hedysarum sulphurescens) 1

SMALL LEAVED EVERLASTING

(Antennaria parviflora) 5

EARLY YELLOW LOCOWEED

(Oxytropis sericea) 6

LOW GOLDENROD

(Solidago missouriensis) 3

\section{GRASSES}

SEDGE

(Carex spp)

$5 \quad-\quad 100$

SLENDER WHEATGRASS

(Agropyron trachycaulum)

JUNEGRASS

(Koeleria macrantha) $\quad 7 \quad-\quad 100$

SHEEP FESCUE

$\begin{array}{lll}\text { (Festuca saximontana) } \quad 2 \quad & - & 100\end{array}$

\section{ENVIRONMENTAL VARIABLES}

MOISTURE REGIME:

SUBXERIC-SUBMESIC

NUTRIENT REGIME:

SUBMESOTROPHIC

ELEVATION:

$1710 \mathrm{M}$

SOIL DRAINAGE:

WELL

SLOPE: $16-30 \%$

ASPECT: SOUTHWESTERLY

ECOLOGICAL STATUS SCORE: 18

\section{FORAGE PRODUCTION(KG/HA)}

GRASS: 1208

FORBS: 292

SHRUBS: 64

TOTAL: 1564

ECOLOGICALLY SUSTAINABLE STOCKING RATE

$2.5(4.0-2.0) \mathrm{HA} / \mathrm{AUM}$ OR

$0.18(0.1-0.2) \mathrm{AUM} / \mathrm{AC}$ 


\section{SASME1. PI/Juniper \\ (Pinus contorta/Juniperus spp.)}

$\mathbf{n}=\mathbf{1}$ Dry site conditions from south exposures or coarse textured soils are characteristic of this community type (Archibald et al. 1996). The dry site conditions limit the amount of forage this site can produce and the steep slope limits access to livestock. As a result, this community would be considered non-use.

Plant Composition Canopy Cover(\%) Mean Range Const.

\section{TREES}

LODGEPOLE PINE

(Pinus contorta)

$15 \quad-\quad 100$

\section{SHRUBS}

GROUND JUNIPER

(Juniperus communis)

CREEPING JUNIPER

(Juniperus horizontalis)

CANADA BUFFALOBERRY

(Shepherdia canadensis) 6

PRICKLY ROSE

(Rosa acicularis)

CHOKE CHERRY

(Prunus virginiana)

3

$$
2
$$

\section{FORBS}

YELLOW HEDYSARUM

(Hedysarum sulphurescens)3 - 100

BEARBERRY

(Arctostaphylos uva-ursi) $8 \quad$ - 100

SPREADING DOGBANE

(Apocynum androsaemifolium) 15 .

LINDLEY'S ASTER

(Aster ciliolatus)

1

-

Grasses

HAIRY WILD RYE

(Elymus innovatus)

SEDGE

$1 \quad-\quad 100$

(Carex spp.)

100

100

\section{ENVIRONMENTAL VARIABLES}

MOISTURE REGIME :

SUBMESIC

NUTRIENT REGIME :

OLIGOTROPHIC

ELEVATION:

$1659 \mathrm{M}$

SOIL DRAINAGE :

RAPIDLY

SLOPE:

$22 \%$

ASPECT:

SOUTH

ECOLOGICAL STATUS SCORE: 18

Forage Production Kg/HA

ECOLOGICALLY SUSTAINABLE STOCKING RATE

GeNERALLY NON-USE

3.0(40.0-2.6) HA/AUM OR

$0.13(.01-0.15) \mathrm{AUM} / \mathrm{AC}$ 


\section{SASME2. PI/Pinegrass \\ (Pinus contorta/Calamagrostis rubescens)}

$\mathbf{n = 1}$ This community type is very similar to the P1/Pinegrass dominated community described in the Montane subregion (Willoughby et al. 2005). Succession will be to white spruce, but the extensive fire history in the area has resulted in a predominance of lodgepole pine (Archibald et al 1996). Pinegrass is generally unpalatable to livestock, but if grazed early in the spring they will utilize it as a forage source. The forage productivity of this community type is quite low. As a result this community type should be rated as non-use.

\section{Plant Composition Canopy Cover(\%)} Mean Range Const.

TREES

LODGEPOLE PINE

(Pinus contorta)

$60 \quad 35-70 \quad 100$

\section{SHRUBS}

PRICKLY ROSE

(Rosa acicularis)

WHITE MEADOWSWEET

(Spiraea betulifolia) 6

DWARF BILBERRY

(Vaccinium caespitosum) 10

GROUND JUNIPER

(Juniperus communis)

$2 \quad 0-3 \quad 75$

$6 \quad 0-10 \quad 75$

$0-19 \quad 75$

$0-4 \quad 50$

\section{FORBS}

TWINFLOWER

(Linneae borealis)

SHOWY ASTER

(Aster conspicuus) 1

CREAM COLORED VETCHLING

(Lathyrus ochroleucus) 1

WILD STRAWBERRY

(Fragaria virginiana) 1

HEART-LEAVED ARNICA

(Arnica cordifolia)

WINTERGREEN

(Pyrola asarifolia)
$3 \quad 0-5 \quad 75$

$0-2 \quad 75$

$1-2 \quad 75$

$1-2 \quad 100$

$0-3 \quad 75$

$1-2 \quad 100$

\section{ENVIRONMENTAL VARIABLES}

MOISTURE REGIME :

MESIC-SUBMESIC

NUTRIENT REGIME :

MESOTROPHIC

ELEVATION:

1665(1618-1730)M

SOIL DRAINAGE :

WELL

SLOPE:

$$
10(5-15) \%
$$

ASPECT:

VARIABLE

ECOLOGICAL STATUS SCORE: 18

\section{Forage Production Kg/HA}

GRASS 179(34-398)

FORB 111(92-122)

SHRUB 81(0-154)

TOTAL 374(166-660)

ECOLOGICALLY SUSTAINABLE STOCKING RATE

GENERALLY NON-USE

$4.9(11-2.8)$ HA/AUM OR

$0.08(0.04-0.14)$ AUM/AC

\begin{tabular}{|c|}
\hline ECOLOGICALLY SUSTAINABLE STOCKING RATE \\
GENERALLY NON-USE \\
$4.9(11-2.8) \mathrm{HA} / \mathrm{AUM}$ OR \\
$0.08(0.04-0.14) \mathrm{AUM} / \mathrm{AC}$ \\
\hline
\end{tabular}

HAIRY WILDRYE

(Elymus innovatus) $\quad 4 \quad 1-4 \quad 100$ 


\section{SASME3. PI-Se/Moss \\ (Pinus contorta-Picea engelmannii/Moss spp.)}

$\mathbf{n}=\mathbf{5} \quad$ This community type represents the modal conditions for the Subalpine subregion at mid to lower elevations. Lodgepole pine, Engelmann spruce and subalpine fir can all occur as the dominant tree species on this ecological site. In general succession is from lodgepole pine to Engelmann spruce and subalpine fir. However, lodgepole pine is the most common tree species because of the frequency of fire.

There is little forage for domestic livestock in this community type. As a result, this community should be rated as non-use.

\section{Plant Composition Canopy Cover(\%)} Mean Range Const.

\section{TREES}

ENGELMANN SPRUCE

(Picea engelmannii)

WHITE SPRUCE

(Picea glauca)

LODGEPOLE PINE

(Pinus contorta)

\section{SHRUBS}

PRICKLY Rose

(Rosa acicularis)

DWARF BILBERRY

(Vaccinium caespitosum) 2

WHITE MEADOWSWEET

(Spiraea betulifolia) $2 \quad 0-5 \quad 80$

GREEN ALDER

(Alnus crispa)

$0-8 \quad 40$

\section{FORBS}

BUNCHBERRY

(Cornus canadensis)

(Fragaria virginiana)

SHOWY ASTER

(Aster conspicuus)

TWINFLOWER

(Linnaea borealis)

BROAD-LEAVED ARNICA

(Arnica latifolia)

$\begin{array}{lll}3 & 0-10 & 40 \\ 2 & 0-10 & 20 \\ 30 & 15-60 & 100\end{array}$

GRASSES

HAIRY WILDRYE

(Elymus innovatus)

PINEGRASS

(Calamagrostis rubescens)3

RICHARDSON NEEDLEGRASS

(Stipa richardsonii)

Moss
(Moss spp)

10

$1-38$

100

\section{ENVIRONMENTAL VARIABLES}

MOISTURE REGIME :

XERIC TO MESIC

NUTRIENT REGIME :

SUBMESOTROPHIC TO MESOTROPHIC

ELEVATION:

1647(1536-1770)M

SOIL DRAINAGE : RAPIDLY TO WELL

SLOPE: $9(0-22) \%$

ASPECT: VARIABLE

ECOLOGICAL STATUS SCORE: 18

\section{Forage Production Kg/Ha}

$\begin{array}{ll}\text { GrASS } & 187 \\ \text { FORB } & 707 \\ \text { SHRUB } & 88 \\ \text { TOTAL } & 981\end{array}$

ECOLOGICALLY SUSTAINABLE STOCKING RATE

GENERALLY NON-USE

$3.0(40.0-2.0) \mathrm{HA} / \mathrm{AUM} \mathrm{OR}$

$0.13(0.01-0.2)$ AUM/AC 


\section{SASME4. Sw-Aw/Alder/Hairy wildrye \\ (Picea glauca-Populus tremuloides/Alnus crispa/Elymus innovatus)}

$\mathbf{n = 1}$ This community type represents the succession of spruce onto an aspen dominated community type. As succession occurs from aspen to spruce there is a corresponding drop in forage production. This community type has little forage available for domestic livestock and should be rated as non-use.

\section{Plant Composition Canopy Cover(\%)} Mean Range Const.

TREES

WHITE SPRUCE

(Picea glauca)

ASPEN

(Populus tremuloides)

LODGEPOLE PINE

(Pinus contorta)

SHRUBS

PRICKLY ROSE

(Rosa acicularis)

DWARF BILBERRY

(Vaccinium caespitosum) $3 \quad$ - 100

WHITE MEADOWSWEET

(Spiraea betulifolia) $\quad 5 \quad-\quad 100$

GREEN ALDER

(Alnus crispa)

$10 \quad-\quad 100$

FORBS

ONE SIDED WINTERGREEN

$\begin{array}{llll}\text { (Orthilia secunda) } & 2 & - & 100\end{array}$

SHOWY ASTER

$\begin{array}{llll}\text { (Aster conspicuus) } & 2 & - & 100\end{array}$

TWINFLOWER

(Linnaea borealis) $\quad 1 \quad$ - 100

GRASSES

HAIRY WILDRYE

(Elymus innovatus) $\quad 3 \quad$ - 100

PINEGRASS

(Calamagrostis rubescens)3 $\quad$ - 100

Moss

(Moss spp)

$10 \quad-\quad 100$

\section{ENVIRONMENTAL VARIABLES}

MOISTURE REGIME :

MESIC

NUTRIENT REGIME : MESOTROPHIC

ELEVATION:

$1557 \mathrm{M}$

SOIL DRAINAGE : WELL

SLOPE: $22 \%$

ASPECT: NORTHERLY

ECOLOGICAL STATUS SCORE: 18

Forage Production KG/HA

TOTAL 155

ECOLOGICALLY SUSTAINABLE STOCKING RATE GENERALLY NON-USE $5.9(40.0-4.0) \mathrm{HA} / \mathrm{AUM}$ OR $0.06(.01-0.1) \mathrm{AUM} / \mathrm{AC}$ 


\section{SASME5. Sw/Willow-Labrador tea \\ (Picea glauca/Salix spp.-Ledum groenlandicum)}

$\mathbf{n}=1$ This community type is characteristic of the rich fen ecosite which is characterized by flowing oxygenated water and alkaline nutrient rich conditions. However, the presence of a high cover of Labrador tea and small bog cranberry indicate this site is somewhat acidic and is tending towards the conditions of the bog ecosite. The bog ecosite tends to be rare in the Subalpine because the higher relief tends to facilitate water movement, which probably explains the transition between the conditions of the two ecosites. The wet conditions of this community type limits livestock accessibility. This community type should be rated non-use.

\section{Plant Composition Canopy Cover(\%)} Mean Range Const.

TREeS

WHITE SPRUCE
(Picea glauca)

35

100

\section{SHRUBS}

WILLOW

(Salix spp.)

BOG BIRCH

(Betula glandulosa)

LABRADOR TEA

(Ledum groenlandicum)

$\begin{array}{lll}19 & - & 100 \\ 12 & - & 100 \\ 20 & - & 100\end{array}$

FORBS

SMALL BOG CRANBERRY

(Oxycoccus microcarpos) 12

TWINFLOWER

(Linnaea borealis)

MITREWORT

(Mitella nuda)

6

\section{2}

GRASSES

SEDGE

(Carex spp)

BALTIC RUSH

(Juncus balticus)

100

\section{ENVIRONMENTAL VARIABLES}

MOISTURE REGIME :

SUBHYDRIC

NUTRIENT REGIME :

MESOTROPHIC

ELEVATION:

$1742 \mathrm{M}$

SOIL DRAINAGE : POORLY

SLOPE: $15 \%$

ASPECT: NORTHERLY

ECOLOGICAL STATUS SCORE: 18

Forage Production Kg/HA

$\begin{array}{ll}\text { GRASS } & 266 \\ \text { FORB } & 44 \\ \text { SHRUB } & 492 \\ \text { TOTAL } & 802\end{array}$

ECOLOGICALLY SUSTAINABLE STOCKING RATE

GENERALlY NON-USE

40.0(40.0-2.0) HA/AUM

$.01(.01-0.2) \mathrm{AUM} / \mathrm{AC}$ 


\section{SUBALPINE CUTBLOCKS}

Cutblocks in the subalpine are common, but generally the areas of the subalpine where cutblocks do occur are not accessible to livestock. Where cutblocks do occur adjacent to grazing areas they can be an important source of forage for domestic livestock. They can produce on average twice as much as deciduous stands and nearly three times more that conifer stands. It must be remembered that this increase in production is only temporary. As the cutblock undergoes succession there will be a corresponding drop in forage production. Increases carrying capacity after harvesting can be acquired through a temporary permit.

It must be remembered that maximum forage productivity does not occur on a cutblock until it is approximately 3 years old. One year old cutblocks will generally have less than half the total production of a 3 year old block. 
Table 7. Cutblock communities of the Southern Rocky Mountains of the Subalpine subregion

\begin{tabular}{|c|c|c|c|c|c|c|c|c|}
\hline \multirow{2}{*}{$\begin{array}{l}\text { Community } \\
\text { number }\end{array}$} & \multirow[t]{2}{*}{ Community type } & \multicolumn{5}{|c|}{ Productivity (kg/ha) } & \multirow[b]{2}{*}{ Drainage } & \multirow{2}{*}{$\begin{array}{l}\text { Carrying } \\
\text { capacity (ha/AUM) }\end{array}$} \\
\hline & & Grass & Forb & Shrub & Total & Moisture & & \\
\hline e3 & false azalea-grouseberry/Se & - & - & - & $600 *$ & Mesic & Well & 3.0 \\
\hline
\end{tabular}

*Estimate 


\section{SASMF1. Pinegrass/Fireweed/Sw \\ (Calamagrostis rubescens/Epilobium angustifolium/Picea glauca)}

$\mathbf{n}=\mathbf{1}$ This community type represents the early successional community of a spruce dominated forest that has been harvested. As succession occurs back to spruce there will be a corresponding drop in forage production. This community type has little forage available for domestic livestock and should be rated as non-use.

\section{Plant COMPOSITION CANOPY COVER(\%)}

\section{Mean Range CONST.}

TREES

WHITE SPRUCE

(Picea glauca)

\section{SHRUBS}

PRICKLY ROSE

(Rosa acicularis)

WHITE MEADOWSWEET

(Spiraea betulifolia) $\quad 10 \quad-\quad 100$

GREEN ALDER

(Alnus crispa)

$5 \quad-\quad 100$

FORBS

FIREWEED

(Epilobium angustifolium 14 - $\quad 100$

PEAVINE

$\begin{array}{llll}\text { (Lathyrus ochroleucus) } \quad 2 \quad & \text { - } & 100\end{array}$

BUNCHBERRY

$\begin{array}{lll}\text { (Cornus canadensis) } & 5 & -\end{array}$

GraSSES

HAIRY WILDRYE

$\begin{array}{llll}\text { (Elymus innovatus) } & 10 & - & 100\end{array}$

PINEGRASS

(Calamagrostis rubescens) $10 \quad$ - $\quad 100$

Moss

(Moss spp)

$10 \quad-\quad 100$

\section{ENVIRONMENTAL VARIABLES}

MOISTURE REGIME :

MESIC

NUTRIENT REGIME : MESOTROPHIC

ELEVATION:

$1440 \mathrm{M}$

SOIL DRAINAGE : WELL

SLOPE: $20 \%$

ASPECT: EASTERLY

HEALTH RATING:

HEALTHY

Forage Production Kg/HA

TOTAL $\quad 600 *$ EsTIMATE

ECOLOGICALLY SUSTAINABLE STOCKING RATE GENERALLY NON-USE 3.0(40.0-2.0) HA/AUM

$0.13(0.01-0.2) \mathrm{AUM} / \mathrm{AC}$ 


\section{ALPINE SUBREGION}

\section{NATIVE GRASSLANDS AND SHRUBLANDS}

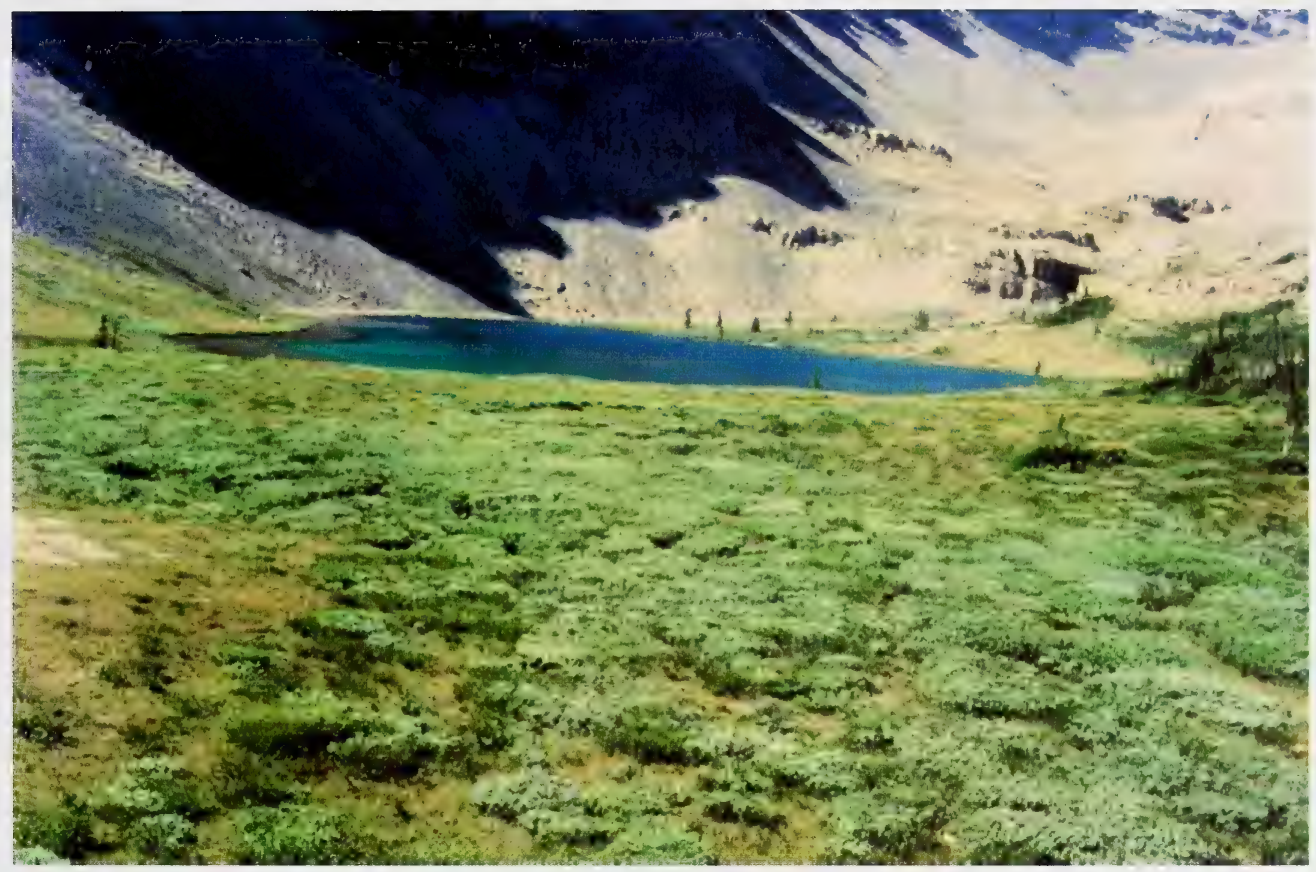

Figure 9. Low growing plant communities of white mountain avens and bog sedge on windswept ridges, with arctic willow, heather and blackening sedge in snow accumulation areas are typical of the Alpine subregion 


\section{Alpine communities}

The alpine environment generally occurs above timberline. Ogilvie (1969), found timberline to be controlled by low temperature, wind dessication, avalanching and snow depth. The alpine plants and communities show adaptations to these extreme environmental conditions. The alpine plant communities tend to be low growing where they are protected from the wind and benefit from the warmer temperatures close to the ground (Ogilvie 1969). Figure 4 outlines the alpine communities in the landscape of the Rocky Mountains. On south facing, wind swept ridges the bog sedge and white dryad communities are found. At slightly lower elevations where snow accumulates the low growing willow communities predominate (arctic willow, snow willow, rock willow). On the north facing slopes where snow accumulates the blackening sedge and heather community types are found. In the valley bottoms below timberline the willow, bog birch, and grassy meadow community types are typical. The sequence of the valley bottom community types in the landscape is described in Figure 3. The ecological sites, ecological site phases and plant community types found in the Alpine subregion are listed in Tables 7 and 8 .

Many of these alpine grass and shrublands are very fragile because of exposure and cold climate. The forage productivity is very low compared to the valley bottoms. Consequently, recovery from overgrazing will likely take some time. As a result grazing by domestic livestock in the Alpine subregion should be discouraged. 
Table 8. Ecological site, ecological site phases and community types for the Alpine subregion(adapted from Beckingham et al. 1996).

\begin{tabular}{||l|l|l||l||}
\hline \multicolumn{1}{|c|}{$\begin{array}{c}\text { Ecological } \\
\text { Site }\end{array}$} & \multicolumn{1}{|c|}{$\begin{array}{c}\text { Ecological } \\
\text { Site } \\
\text { Phase }\end{array}$} & \multicolumn{1}{|c|}{$\begin{array}{c}\text { Reference Range Plant } \\
\text { Community }\end{array}$} & $\begin{array}{c}\text { Successional } \\
\text { Community } \\
\text { Types }\end{array}$ \\
\hline \hline $\begin{array}{l}\text { a lichen stone fields } \\
\text { (subxeric/very poor) }\end{array}$ & al lichen & ALPA7 Lichen & \\
\hline $\begin{array}{l}\text { b mountain avens- } \\
\text { bog sedge } \\
\text { (submesic/poor) }\end{array}$ & b1 bog sedge & ALPA1 Bog sedge & \\
\cline { 2 - 5 } & b2 mountain avens & ALPA2 White mountain avens & \\
\hline \multirow{2}{*}{$\begin{array}{c}\text { c heather } \\
\text { (mesic/medium) }\end{array}$} & c1 heather & ALPA3 Mountain heather & \\
\hline $\begin{array}{l}\text { d snowpatch seepages } \\
\text { (subhygric/medium) }\end{array}$ & d1 blackening sedge & ALPA4 Blackening sedge & \\
\cline { 2 - 5 } & d2 simple bog sedge & ALPA5 Simple bog sedge & \\
\cline { 2 - 5 } & d3 arctic willow & ALPA6 Arctic willow & \\
\hline
\end{tabular}




\section{a lichen stone fields $(\mathrm{n}=6)$}

\section{GENERAL DESCRIPTION}

This ecosite occurs on subxeric to xeric Alpine sites at elevations from $2400-2800 \mathrm{~m}$ on various slopes and aspects. The soils are Orthic Regosols or non-soil occurring on Rockland or Colluvial Rubble. This ecosite is only sparsely vegetated with less than $20 \%$ plant cover with lichens contributing to most of the cover

\section{SUCCESSIONAL RELATIONSHIPS}

This ecosite is characteristic of weakly or non-calcareous sites and is successionally mature.

\section{INDICATOR SPECIES}

sedge

lichen
Surface texture:

Effective texture:

Depth to Mottles/Gley: none

Drainage: very rapidl

Parent material: $\mathrm{C}, \mathrm{R}$

Soil subgroup:, O.R

\section{ECOSITE PHASES}

al lichen $(n=6)$

\section{subxeric/medium}

\section{SITE CHARACTERISTICS}

Moisture regime: subxeric, xeric

Nutrient regime: very poor

Topographic position: crest, upper slope

Slope: $3-70 \%$

Aspect: variable

\section{SOIL CHARACTERISTICS}

Organic thickness: $(0-2)$

Humus form: 


\section{CHARACTERISTIC SPECIES}

\section{Shrubs}

[1] Willow

\section{Forbs}

$\begin{array}{ll}\text { [1] } & \text { Inflated oxytrope } \\ \text { 1 ] } & \text { Moss campion }\end{array}$

\section{Graminoids}

[1]

Sedge

Lichen

[7]

\section{SITE CHARACTERISTICS}

Moisture regime: subxeric, xeric

Nutrient regime: very poor

Topographic position: crest, upper slope

Slope: (0-70)

Aspect: variable

\section{SOIL CHARACTERISTICS}

Organic thickness: $(0-5)$

Humus form:

Surface texture:

Effective texture:

Depth to Mottles/Gley:

Drainage: very rapid

Parent material: C, R

Soil subgroup:, O.R

\section{COMMUNITY TYPES}

ALPA7. Lichen $(n=6)$ 
b mountain avens-bog sedge $(n=48)$

\section{GENERAL DESCRIPTION}

This ecosite occurs on south and west facing windswept ridges throughout the mountains. The soils are well drained Orthic Regosols, Orthic Humic Regosols, or Orthic Melanic, Orthic Sombric and Orthic Eutric Brunisols. Turbic and Lithic soil phases are common (Corns and Achuff 1982). The landforms are predominantly morainal and colluvial.

\section{SUCCESSIONAL RELATIONSHIPS}

This ecosite is successionally mature

\section{INDICATOR SPECIES}

white mountain heather

northern white mountain avens

white mountain avens

hairy wildrye

bog sedge

\section{submesic/poor}

\section{SITE CHARACTERISTICS}

Moisture regime: subxeric, submesic, mesic

Nutrient regime: very poor, poor

Topographic position: crest and upper slope

Slope: $(0-70)$

Aspect: southerly, westerly

\section{SOIL CHARACTERISTICS}

Organic thickness: (0-5)

Humus form:

Surface texture:

Effective texture:

Depth to Mottles/Gley: none

Drainage: very rapidly, well

Parent material: $\mathrm{C}, \mathrm{M}$

Soil subgroup:, O.R, O.HR, O.MB, O.EB, O.SB

\section{ECOSITE PHASES}

b1 bog sedge $(n=5)$

b2 mountain avens $(n=43)$ 


\section{CHARACTERISTIC SPECIES}

\section{Shrubs}

[3]

[3]

Smooth willow

Bog birch

Forbs

[2]

[2]

Northern white mtn. avens

[5]

White mtn. avens

Alpine hedysarum

Graminoids

[44]

[4]

Bog sedge

Hairy wildrye

\section{SITE CHARACTERISTICS}

Moisture regime: subxeric, submesic, mesic

Nutrient regime: very poor, poor

Topographic position: crest and upper slope

Slope: (0-70)

Aspect: southerly, westerly

\section{SOIL CHARACTERISTICS}

\section{Organic thickness: (0-5)}

Humus form:

Surface texture:

Effective texture:

Depth to Mottles/Gley: none

Drainage: very rapidly, well

Parent material: C, M

Soil subgroup:, O.R, O.HR, O.MB, O.EB, O.SB

\section{COMMUNITY TYPES}

ALPA1 Bog sedge( $n=5)$ 


\title{
CHARACTERISTIC SPECIES
}

\section{Shrubs}

[2] Snow willow

\section{Forbs}

[16]

[17]

[3]

[1]

[1]

\author{
Northern white mtn. avens \\ White mtn. avens \\ White mountain heather \\ Moss campion \\ Prairie selaginella
}

\section{Graminoids}
[3]
[1]
Bog sedge
Hairy wildrye

\section{SITE CHARACTERISTICS}

Moisture regime: subxeric, submesic, mesic

Nutrient regime: very poor, poor

Topographic position: crest and upper slope

Slope: (0-70)

Aspect: southerly, westerly

\section{SOIL CHARACTERISTICS}

Organic thickness: $(0-5)$

Humus form:

Surface texture:

Effective texture:

Depth to Mottles/Gley: none

Drainage: very rapidly, well

Parent material: $\mathrm{C}, \mathrm{M}$

Soil subgroup:, O.R, O.HR, O.MB, O.EB, O.SB

\section{COMMUNITY TYPES}

ALPA2 White Mountain Avens $(n=43)$ 


\section{GENERAL DESCRIPTION}

This ecosite occurs on mesic, level to steeply sloping sites of various aspects at elevations from 2000 to $2500 \mathrm{~m}$. Soils are well to moderately developed well drained Eutric and Dystric Brunisols, Orthic Humo-Ferric Podzols and Melanic and Sombric Brunisols developed on morainal and residual landforms.

\section{SUCCESSIONAL RELATIONSHIPS}

This ecosite is successionally mature

\section{INDICATOR SPECIES}

western mountain-heather

white mountain heather

red heather

yellow heather

willow

\section{mesic/medium}

\section{SITE CHARACTERISTICS}

Moisture regime: mesic

Nutrient regime: medium

Topographic position: crest and upper slope

Slope: $(0-70)$

Aspect: northerly

\section{SOIL CHARACTERISTICS}

Organic thickness: $(0-5)$

Humus form:

Surface texture:

Effective texture:

Depth to Mottles/Gley: none

Drainage: well

Parent material: $\mathrm{C}, \mathrm{R}$

Soil subgroup:, O.HFP, O.DYB, O.MB, O.EB, O.SB

\section{ECOSITE PHASES}




\title{
CHARACTERISTIC SPECIES
}

\section{Shrubs}

[13 ] willow

\section{Forbs}

[27]

[5]

[1]

[20]

[1]

[1]

\author{
Western mountain heather \\ Red heather \\ White mountain heather \\ Yellow heather \\ Western anemone \\ Woolly everlasting
}

\section{Graminoids}

[1] Sedge

\section{SITE CHARACTERISTICS}

Moisture regime: mesic

Nutrient regime: medium

Topographic position: crest and upper slope

Slope: $(0-70)$

Aspect: northerly

\section{SOIL CHARACTERISTICS}

Organic thickness: $(0-5)$

Humus form:

Surface texture:

Effective texture:

Depth to Mottles/Gley: none

Drainage: well

Parent material: $\mathrm{C}, \mathrm{R}$

Soil subgroup:, O.HFP, O.DYB, O.MB, O.EB, O.SB

\section{COMMUNITY TYPES}

ALPA3 Mountain heather $(n=58)$ 


\section{GENERAL DESCRIPTION}

This ecosite occupies well to imperfectly drained sites with mesic to subhygric moisture regimes. It occurs on a variety of slopes and aspects. Soils vary from Humic Regosols, Dystric Brunisols, Gleysols, Sombric Brunisols and HumoFerric Podzols and occupies morainal and fluvial landforms(Corns and Achuff 1982). This ecosite occurs in deep snow accumulation areas and often recieves seepage for much of the growing season.

\section{SUCCESSIONAL RELATIONSHIPS}

This ecosite is successionally mature

\section{INDICATOR SPECIES}

woolly everlasting

blackening sedge

simple bog sedge

arctic willow

\section{subhygric/medium}

\section{SITE CHARACTERISTICS}

Moisture regime: mesic, subhygric

Nutrient regime: medium

Topographic position: lower slope, toe, depression

Slope: $(0-45)$

Aspect: northerly, variable

\section{SOIL CHARACTERISTICS}

Organic thickness: $(0-5)$

Humus form:

Surface texture:

Effective texture:

Depth to Mottles/Gley: none

Drainage: well, moderately well, Imperfect

Parent material: FL, M

Soil subgroup:, O.HFP, O.DYB, O.HR, O.SB 


\section{CHARACTERISTIC SPECIES}

Forbs

[1] Mountain buttercup

[ 7 ] Mountain marsh marigold

[6] Woolly everlasting

\section{Graminoids}

[49]

[4] tufted hairgrass

black alpine sedge

[2] mountain wood rush

[4] mountain hair grass

\section{SITE CHARACTERISTICS}

Moisture regime: mesic, subhygric

Nutrient regime: medium

Topographic position: lower slope, toe, depression

Slope: (0-45)

Aspect: northerly, variable

\section{SOIL CHARACTERISTICS}

Organic thickness: $(0-5)$

Humus form:

Surface texture:

Effective texture:

Depth to Mottles/Gley: none

Drainage: well, moderately well, Imperfect

Parent material: FL, M

Soil subgroup:, O.HFP, O.DYB, O.HR, O.SB

\section{COMMUNITY TYPES}

ALPA4 Blackening sedge $(n=5)$ 


\section{CHARACTERISTIC SPECIES}

Shrubs

[2] bog birch

[3] arctic willow

Forbs

[ 8 ] dwarf false asphosel

[5] yellow mountain saxifrage

[2] small wood anemone

\section{Graminoids}

[25] simple bog-sedge

\section{SITE CHARACTERISTICS}

Moisture regime: mesic, subhygric

Nutrient regime: medium

Topographic position: lower slope, toe, depression

Slope: $(0-45)$

Aspect: northerly, variable

\section{SOIL CHARACTERISTICS}

Organic thickness: $(0-5)$

Humus form:

Surface texture:

Effective texture:

Depth to Mottles/Gley: none

Drainage: well, moderately well, Imperfect

Parent material: FL, M

Soil subgroup:, O.HFP, O.DYB, O.HR, O.SB

\section{COMMUNITY TYPES}

ALPA5 Simple bog sedge $(n=1)$ 


\section{CHARACTERISTIC SPECIES}

\section{Shrubs}

[6]

[17]

[4]

rock willow

arctic willow

snow willow

Forbs

[ 7 ] woolly everlasting

\section{Graminoids}

$\begin{array}{ll}{[1]} & \text { simple bog-sedge } \\ {[3]} & \text { black alpine sedge } \\ {[1]} & \text { hairy wildrye } \\ {[1]} & \text { mountain timothy }\end{array}$

\section{SITE CHARACTERISTICS}

Moisture regime: mesic, subhygric

Nutrient regime: medium

Topographic position: lower slope, toe, depression

Slope: (0-45)

Aspect: northerly, variable

\section{SOIL CHARACTERISTICS}

Organic thickness: $(0-5)$

Humus form:

Surface texture:

Effective texture:

Depth to Mottles/Gley: none

Drainage: well, moderately well, Imperfect

Parent material: FL, M

Soil subgroup:, O.HFP, O.DYB, O.HR, O.SB

\section{COMMUNITY TYPES}

ALPA6 Arctic willow $(\mathrm{n}=20)$ 
Table 9. Native grass and shrublands of the Alpine subregion organized by ecological site phase

$\begin{array}{llll}\begin{array}{l}\text { Community } \\ \text { number }\end{array} & \text { Community type } & \text { Groductivity }(\mathrm{kg} / \mathrm{ha}) & \text { Pros }\end{array}$ Forb Shrub Total Moisture Drainage $\quad \begin{aligned} & \text { Carrying } \\ & \text { capacity (ha/AUM) }\end{aligned}$

\begin{tabular}{llllll}
\hline a1 & lichen & N/A & Xeric & Very rapidly Non-use \\
ALPA7 & Lichen stonefield & N/A & Xeric & Very rapidly & Non-use \\
b1 & bog sedge & N/A & Subxeric & Rapidly & Non-use \\
ALPA1. & Bog sedge & N/A & Subxeric & Rapidly & Non-use \\
b2 & white mountain avens & N/A & Subxeric & Rapidly & Non-use \\
ALPA2. & White Mountain Avens & N/A & Subxeric & Rapidly & Non-use \\
c1 & heather & N/A & Submesic & Well & Non-use \\
ALPA3. & Mountain heather & N/A Submesic & Well & Non-use \\
d1 & blackening sedge & N/A & Subhygric & Mod. Well & Non-use \\
ALPA4. & Blackening sedge & N/A Subhygric & Mod. Well Non-use \\
d2 & simple bog sedge & N/A Subhygric & Mod. Well Non-use \\
ALPA5. & Simple bog sedge & N/A Subhygric & Mod. Well Non-use \\
d3 & arctic willow & N/A Subhygric & Mod. Well Non-use \\
ALPA6. & Arctic willow & N/A Subhygric & Mod. Well Non-use
\end{tabular}




\section{ALPA1. Bog sedge \\ (Kobresia myosuroides)}

$\mathbf{n}=\mathbf{5}$ This community type occurs at higher elevations on snow-free, wind-exposed south facing slopes and ridge crests. The soils are shallow, stoney colluvial Regosols (Corns and Achuff 1982). Ogilvie (1969), found that there was rich herb layer, and an abundant lichen and bryophyte layer in this community type.

\section{Plant Composition Canopy Cover(\%) Mean Range Const.}

\section{SHRUBS}

SMOOTH WILLOW

$\begin{array}{llll}\text { (Salix glauca) } & 3 & 0-8 & 60\end{array}$

BOG BIRCH

$\begin{array}{llll}\text { (Betula glandulosa) } & 3 & 0-7 & 60\end{array}$

WHITE MOUNTAIN AVENS

(Dryas integrifolia,
D. octopetala)
4
$0-7 \quad 40$

\section{FORBS}

ALPINE HEDYSARUM

$\begin{array}{llll}\text { (Hedysarum alpinum) } & 5 & 0-8 & 80\end{array}$

LITTLE CLUBMOSS

(Selaginella densa) $\quad 1 \quad 0-3 \quad 40$

ALPINE BISTORT

$\begin{array}{llll}\text { (Polygonum viviparum) } & 2 & 0-4 & 60\end{array}$

SMOOTH LEAVED CINQUEFOIL

(Potentilla diversifolia) 1

$0-2 \quad 60$

\section{GRASSES}

BOG SEDGE

(Kobresia myosuroides) $44 \quad 35-65 \quad 100$

HAIRY WILDRYE

$\begin{array}{llll}\text { (Elymus innovatus) } & 4 & 0-10 & 80\end{array}$

ROCKY MTN. FESCUE

(Festuca saximontana) $\quad 1 \quad 0-5 \quad 40$

\section{ENVIRONMENTAL VARIABLES}

MOISTURE REGIME:

SUBXERIC

NUTRIENT REGIME:

OLIGOTROPHIC

ELEVATION:

2042(1900-2260) M

SOIL DRAINAGE:

RAPIDLY

SLOPE:

$0-48(19) \%$

ASPECT:

SOUTH -SOUTHWEST

Forage Production KG/HA

ECOLOGICALLY SUSTAINABLE STOCKING RATE NON-USE 


\section{ALPA2. White mountain avens \\ (Dryas octopetala, D. integrifolia)}

$\mathbf{n}=43$ This community type occurs on wind-exposed, snow-free ridges. The soils are shallow, stoney, colluvial Regosols (Corns and Achuff 1982). Ogilvie (1969), found this community to have an abundance of cushion and mat-plants and a large number of lichens.

\section{Plant Composition Canopy Cover(\%) Mean RANGe CONST.}

\section{SHRUBS}

WHITE MOUNTAIN AVENS

(Dryas octopetala,

D. integrifolia)

SNOW WILLOW

(Salix reticulata) 2

WHITE MOUNTAIN HEATHER

(Cassiope tetragona) 3

\section{FORBS}

ELEPHANT'S HEAD

(Pedicularis groenlandicum) $\mathrm{T}$

WOOLY EVERLASTING

(Antennaria lanata)

MOSS CAMPION

(Silene acaulis)

ALPINE BISTORT

(Polygonum viviparum)

LITTLE CLUBMOSS

(Selaginella densa)

$\begin{array}{lll}1 & 0-25 & 19 \\ 1 & 0-5 & 72 \\ 1 & 0-5 & 65 \\ 1 & 0-15 & 33\end{array}$

\section{ENVIRONMENTAL VARIABLES}

MOISTURE REGIME:

SUBXERIC

NUTRIENT REGIME:

SUBMESOTROPHIC

ELEVATION:

$$
\text { 2192(1410-2490) M }
$$

SOIL DRAINAGE:

RAPIDLY

SLOPE:

$$
0-60(25) \%
$$

ASPECT:

$$
\text { EAST TO WEST }
$$

\section{FORAGE PRODUCTION}

BOG SEDGE

(Kobresia myosuroides) $3 \quad 0-35 \quad 35$

SEDGE SPP.

$\begin{array}{llll}\text { (Carex spp.) } & 2 & 0-65 \quad 77\end{array}$

SPIKED TRISETUM

(Trisetum spicatum)

$0-7 \quad 42$

ECOLOGICALLY SUSTAINABLE STOCKING RATE NON-USE 


\section{ALPA3. Mountain heather \\ (Cassiope spp.-Phyllodoce spp.)}

$\mathbf{n = 5 8}$ This community type occurs on north facing slopes, with deep snow cover. The soils are Brunisolic, Podzolic and Regosolic and they have seepage and solifluction (Corns and Achuff 1982). Ogilvie (1969), found this community type to have an abundant low shrub layer, a rich byrophyte and lichen layer and a moderately developed herb layer.

This community type includes both the Cassiope tetragona-Dryas octopetala-Salix nivalis and Phyllodoce glanduliflora-Cassiope mertensiana-Antennaria lanata community types described by Corns and Achuff (1982).

\section{Plant Composition Canopy Cover(\%)} Mean Range Const.

\section{SHRUBS}

WILLOW SPP.

(Salix spp.)

$13 \quad 0-30$

67

WESTERN MOUNTAIN HEATHER

(Cassiope mertsiana) 27

WHITE MOUNTAIN HEATHER

(Cassiope tetragona)

YELLOW HEATHER

(Phyllodoce glanduliflora) 20

RED HEATHER

(Phyllodoce empetriformis) 5

40

\section{FORBS}

LANCED -LEAVED PAINT BRUSH

(Castilleja occidentalis) T

WOOLLY EVERLASTING

(Antennaria lanata) $3 \quad 0-15 \quad 85$

WESTERN ANEMONE

(Anemone occidentalis) 1

MOUNTAIN SAGE

(Artemisia norvegica)

GRASSES

REDDISH WOOD RUSH

(Luzula piperi)

SEDGE

(Carex spp.)

$0-75 \quad 86$

$0-15 \quad 16$

$0-60 \quad 20$

$0-30 \quad 26$

$0-15 \quad 53$

\section{Forage Production Kg/HA}

NoT AVAILABLE

ECOLOGICALLY SUSTAINABLE STOCKING RATE NON-USE 


\section{ALPA4. Blackening sedge \\ (Carex nigricans)}

$\mathbf{n = 7} \quad$ This is a snowpatch community occurring in small channels and depressions where there is very deep snow accumulation (Ogilvie 1969). The soils are predominantly Brunisols, Podzols and Regosols and are moist and free of snow for only a brief period of time (Corns and Achuff 1982). Ogilvie (1969) found these community types to have an abundant herb layer of sedges, grasses and forbs, with only a minor occurrence of dwarf shrubs and mosses.

Plant Composition Canopy Cover(\%) Mean Range Const.

SHRUBS

WILLOW

(Salix spp)

$\mathrm{T}$

$0-2$

14

\section{FORBS}

WOOLLY EVERLASTING

(Antennaria lanata)

MOUNTAIN MARIGOLD

(Caltha leptosepala)

MOUNTAIN BUTTERCUP

(Ranunculus eschscholtzii)1

MARE'S TAIL

(Hippus vulgaris)

GRASSES

BLACKENING SEDGE

(Carex nigricans)

TUFTED HAIRGRASS

(Deschampsia caespitosa) 4

REDDISH WOOD RUSH

(Luzula piperi)

(Vahlodea atropurpurea) 4

WHITE RUSH

(Juncus albescens)
2

0-12

14

49

$0-40 \quad 43$

$0-5 \quad 29$

$0-90 \quad 100$

$0-30 \quad 14$

$0-8 \quad 57$

$0-15 \quad 57$

$0-15 \quad 14$

$2 \quad 0-15 \quad 14$

$\begin{array}{lll}6 & 0-34 \quad 57\end{array}$

\section{ENVIRONMENTAL VARIABLES}

MOISTURE REGIME:

MESIC TO SUBHYGRIC

NUTRIENT REGIME:

MESOTROPHIC

ELEVATION:

$$
\text { 2164(1990-2240) M }
$$

SOIL DRAINAGE:

MODERATELY WELL

SLOPE:

$$
25(1-64) \%
$$

ASPECT:

$$
\text { NORTHERLY }
$$

Forage Production KG/HA
ECOLOGICALLY SUSTAINABLE STOCKING RATE NON-USE 


\section{ALPA5. Simple bog sedge (Kobresia simpliciuscula)}

$\mathbf{n = 1}$ This community type was described at only one site. Simple bog sedge is typical of boggy areas at higher elevations. This community type was described on a poorly drained, level site at higher elevations. It is likely found in association with the willow and sedge dominated community types found in the valley bottoms of the lower alpine and upper subalpine.

Plant COMPOSITION CANOPY COVER(\%) Mean Range Const.

\section{SHRUBS}

WILLOW SPP.

(Salix spp.)

BOG BIRCH

(Betula glandulosa)

$3 \quad-$

100

FORBS

BOG ASPHODEL

(Tofieldia pusilla)

YELLOW MOUNTAIN SAXIFRAGE

(Saxifraga aizoides)

SMALL WOOD ANEMONE

(Anemone parviflora)

BROAD LEAVED FIREWEED

(Epilobium latifolium) 2

ALPINE BISTORT

(Polygonum viviparum)

100

100

100

100

100

\section{ENVIRONMENTAL VARIABLES}

MOISTURE REGIME:

SUBHYGRIC

NUTRIENT REGIME:

PERMESOTROPHIC

ELEVATION:

$1900 \mathrm{M}$

SOIL DRAINAGE:

MODERATELY WELL

Forage Production KG/Ha

MODERATELY WELL

\section{Grasses}

SIMPLE BOG SEDGE

(Kobresia simpliciuscula)25

BALTIC RUSH

(Juncus balticus)

100 


\section{ALPA6. Arctic willow (Salix arctica)}

$\mathbf{n = 2 0}$ This dwarf shrub community occurs in areas of deep snow accumulation, on soils which receive seepage for much of the growing season (Corns and Achuff 1982). Ogilvie (1969), found that there was a rich herb layer of sedges, grasses and forbs and an abundant dwarf shrub layer. This community is similar to the blackening sedge community previously described, but it appears melt out occurs earlier in this community type (Corns and Achuff 1982)

\section{Plant Composition CANOPY COVER(\%)} Mean Range Const.

\section{SHRUBS}

ARCTIC WILLOW .

(Salix arctica)

SNOW WILLOW

(Salix reticulata)

ROCK WILLOW

(Salix vestita)

\section{FORBS}

WOOLY EVERLASTING

(Antennaria lanata)

WILD STRAWBERRY

(Fragaria virginiana) $\mathrm{T}$

SMOOTH LEAVED CINQUEFOIL

(Potentilla diversifolia) 1

MOUNTAIN SAGE

(Artemisia norvegica) 2

ALPINE BISTORT

(Polygonum viviparum)

$\begin{array}{lll}17 & 0-50 & 80 \\ 4 & 0-30 & 40 \\ 6 & 0-65 & 15\end{array}$

$7 \quad 0-35 \quad 50$

$0-5 \quad 15$

$0-3 \quad 35$

0-5 50

$0-5 \quad 55$
Grasses

SEDGE

(Carex spp)

HAIRY WILDRYE

(Elymus innovatus)

MOUNTAIN TIMOTHY

(Phleum commutatum)
$3 \quad 0-20 \quad 35$

$1 \quad 0-15 \quad 5$

$1 \quad 0-10 \quad 25$

\section{ENVIRONMENTAL VARIABLES}

MOISTURE REGIME:

MESIC TO SUBHYGRIC

NUTRIENT REGIME:

MESOTROPHIC

ELEVATION:

2141(1830-2330)M

SOIL DRAINAGE:

MODERATELY WELL TO IMPERFECT

SLOPE:

$25(11-58) \%$

ASPECT:

VARIABLE

Forage Production Kg/Ha

ECOLOGICALLY SUSTAINABLE STOCKING RATE NON-USE 


\section{ALPA7. Lichen stonefield \\ (Cetraria spp., Lecanora spp., Rhizocarpon spp., Thamnolia spp.)}

n=6 Corns and Achuff (1982) described this community type on ridge tops at elevations up to $2800 \mathrm{~m}$. They felt this community type was characteristic of weakly on non-calcareous sites and it was successionally mature.

This community type is characteristic of very low plant cover $(<20 \%)$ which is dominated by lichens.

\section{Plant Composition Canopy Cover(\%) Mean Range Const.}

\section{SHRUBS}

SNOW WILLOW

(Salix reticulata)

$1 \quad 0-2 \quad 50$

\section{FORBS}

LitTLE CluBMoss

(Selaginella densa)

INFLATED OXYTROPE

(Oxytropis podocarpa)

MOSS CAMPION

(Silene acaulis)

PURPLE SAXIFRAGE

(Saxifraga oppositifolia) 1

\section{GRASSES}

SEDGE

(Carex spp)

SPIKED TRISETUM

(Trisetum spicatum)

\section{LICHENS}

Cetraria tilesii

Lecanora varia

Rhizocarpon

geographicum

Thamnolia subuliformis

\section{ENVIRONMENTAL VARIABLES}

MOISTURE REGIME:

XERIC

NUTRIENT REGIME:

OLIGOTROPHIC

ELEVATION:

2600(2400-2800)M

SOIL DRAINAGE:

VERY RAPID

SLOPE:

$25(11-58) \%$

ASPECT:

VARIABLE

Forage Production Kg/HA

ECOLOGICALLY SUSTAINABLE STOCKING RATE NON-USE 


\section{Literature cited}

Adams, B.W., G.Ehlert, C.Stone, M. Alexander, D. Lawrence, M. Willoughby, D. Moisey, C. Hincz and A. Bogen.2003. Range Health Assessement for Grassland, Forest and Tame Pasture. Public Lands Division, Alberta Sustainable Resource Development. Pub. No. $\mathrm{T} / 044105 \mathrm{pp}$.

Archibald, J.H., G. Klappstein and I.G.W. Corns. 1996. Field guide to ecosites of Southwestern Alberta. Nat. Resour. Can., Can. For. Serv. Northwest Reg., North. For. Cent., Edmonton, AB. Spec rep. no. 8.

Bailey, A.W., M.G. Willoughby, R. Johansen and S. Smith. (1992) Management of Yukon Rangelands. Renewable Resources, Yukon Territorial Government, Whitehorse, Yukon. 55pp. ISBN-1-55018-138-6.

Bork, E. 1990. Clearwater allotment: Prescribed burn vegetation survey, evaluation, and discussion. Range Management Section, Alberta Forest Service, Edmonton, Alta. 29pp.

Bork, E. 1994. Ecological classification and management of native ranges in Willmore Wilderness Park. Range management section, Alberta Environmental Protection. Edmonton, Alta. Pub. no. T/282 65pp.

Beckingham, J., I.G.W. Corns and J.H. Archibald. 1996. Field guide to Ecosites of WestCentral Alberta. Nat. Resour. Can., Can. For. Serv. Northwest Reg., North. For. Cent., Edmonton, AB. Spec rep. no. 9.

Beckingham, J. and J.H. Archibald. 1996. Field guide to ecosites of Northern Alberta. Nat. Resour. Can., Can. For. Serv. Northwest Reg., North. For. Cent., Edmonton, AB. Spec rep. no. 5.

Corns, I.G.W. and P. Achuff. 1982. In Ecological (Biophysical) Land Classification of Banff and Jasper National Parks. Vol II: Soil and Vegetation Resources. Edited by Holland, W.D. and G.M. Coen. Environment Canada and Alberta Institute of Pedology, University of Alberta. Pub. no. SS-82-44. 540pp.

Corns, I.G.W. and R.M. Annas. 1986. Field guide to forest ecosystems of West-Central Alberta. Northern Forestry Center, Canadian Forestry Service, Edmonton, Alta. 251pp.

Daubenmire, R. 1952. Forest vegetation of Northern Idaho and adjacent Washington and its bearing on concepts of vegetation classification. Ecol. Mongr. 22: 301-330.

Department of Environmental Protection. 1994. Natural Regions of Alberta. Alberta Environmental Protection. Edmonton, Alta. Pub. no.: I/531. 18pp. 
Gauch, H.G. 1982. Multivariate analysis in community ecology. Cambridge University Press, Cambridge, 298pp.

Holechek, J.L., R.D. Pieper and C.H.Herbel. 1995. Range management principles and practices. $2^{\text {ed }}$. Prentice-Hall Inc. Engewood Cliff. New Jersey. Chapter 8.

Holland, W.D. and G.M. Coen. 1982. Ecological (Biophysical) Land Classification of Banff and Jasper National Parks. Vol II: Soil and Vegetation Resources. Environment Canada and Alberta Institute of Pedology, University of Alberta. Pub. no. SS-82-44. 540pp.

Jaques, D.R. 1976. Winter alpine-subalpine wildlife habitat in the southern Rocky Mountains of Alberta. Kananaskis Center for Environmental Research, University of Calgary. Calgary, Alta. 113pp.

Lawrence, D., C.T. Lane, M.G.Willoughby, C.Hincz, D. Moisey and C. Stone. 2005. Range plant community types and Carrying capacity for the Lower Foothills Subregion. $4^{\text {th }}$ Approximation. Alberta Sustainable Resource Development. Public Lands and Forest Division. Edmonton. Pub.no. T/083. 232 pp.

Mackinnon, A., J. Pojar and R. Coupe. 1992. Plants of Northern British Columbia. Lone Pine Publishing, Edmonton, Alta. 345pp.

Mueggler, W.F. 1988. Aspen community types of the Intermountain Region. U.S.D.A. Intermoutain Research Station. INT-250. 133pp.

Morgantini, L. E. and W.B. Russell. 1983. An assessement of three selected elk winter ranges in the Rocky Mountains Region. Alberta Fish and Wildlife Division. Edmonton. AB. 264pp.

Moss, E.H. and J.W. Campbell. 1947. The fescue grassland of Alberta. Can. J. Res. 25:209-227.

Ogilvie, R.T. 1969. The Mountain Forest and Alpine Zones of Alberta. In, Vegetation, Soils and Wildlife. edited by J.G. Nelson and M.J. Chambers. Methuen Publications, Toronto. pg 24-44.

Range Survey Manual. 1992. Range Management Section, Alberta Forest Service. Edmonton, Alta. 39pp.

Scoggan, H.J. 1978. The Flora of Canada. National Museum of Natural Sciences, Publications in Botany, Ottawa, Canada. No. 7(2).

Stringer, P.W.1973. An ecological study of grasslands in Banff, Jasper and Waterton National Parks. Can. J. Bot. Vol. 51. 383-411. 
Strong, W.L. 1992. Ecoregions and ecodistricts of Alberta. Vol 1. Alberta Forestry Lands and Wildlife, Land Information Services Division, Resource Information Branch, Edmonton, Alta. T/244. 77pp.

Strong, W.L. and J.M. Thompson. 1995. Ecodistricts of Alberta: Summary of Biophysical Attributes. Alberta Environmental Protection, Resource Data Division. Edmonton, Alta. Pub. no. T/319. 91pp.

Strong, W.L. and K.R. Leggat. 1992. Ecoregions of Alberta. Alberta Forestry, Lands and Wildlife, Resource Information Branch, Edmonton, Alta. T/245. 77pp.

Task Group on Unity in Concept and Terminology. 1995. New concepts for assessment of rangeland condition. J. Range Manage. 48:271-225. $191 \mathrm{pp}$.

Wilkinson, K. 1990. Trees and shrubs of Alberta. Lone Pine Publishing. Edmonton. Alta.

Willoughby, M.G. 1992. Rangeland Reference Areas, Plant communities, ecology and response to grazing in Division 3. Forestry, Lands and Wildlife, Alberta Forest Service, Edmonton, Alta. Pub. no. T/269. 36pp.

Willoughby, M.G. 1992. Rangeland Reference Areas, Plant communities, ecology and response to grazing in Division 2. Forestry, Lands and Wildlife, Alberta Forest Service, Edmonton, Alta. Pub. no. T/268. 42pp.

Willoughby, M.G. 1998. Rangeland Reference Areas, Seven mile creek range condition and trend from 1953-1994. Environmental Protection, Lands and Forest Service. Edmonton, Alta. Pub. No. T/403. 21 pp.

Willoughby, M.G. 2005. Range plant community types and carrying capacity for the Upper Foothills subregion . $5^{\text {th }}$ Approximation. Sustainable Resource Development. Public Lands and Forests Division, Alta. Pub. no. T/068. 129pp.

Willoughby, M.G., M.J. Alexander and B.W. Adams. 2005. Range plant communities and carrying capacity for the Montane subregion. $6^{\text {th }}$ Approximation. Sustainable Resource Development. Public Lands and Forests Division. Pub. No. T/071. 235pp. 
LIBRARY AND ARCHIVES CANADA 